\title{
Value Impacts of Energy Efficiency Retrofits on Commercial Office Buildings in Toronto, Canada
}

\author{
by \\ Kaitlin Carlson \\ A thesis submitted in conformity with the requirements \\ for the degree of Master of Applied Science \\ Department of Civil Engineering \\ University of Toronto
}

(C) Copyright by Kaitlin Carlson 2015 


\title{
Value Impacts of Energy Efficiency Retrofits on Commercial Office Buildings in Toronto, Canada
}

\author{
Kaitlin Carlson \\ Master of Applied Science \\ Department of Civil Engineering \\ University of Toronto
}

2015

\begin{abstract}
The intent of this thesis is to strengthen the business case for sustainable building in Canada by studying the relationship between building energy efficiency and value. This is accomplished through detailed examination of four Toronto commercial office building retrofit case studies with quantitative pre- and post-retrofit energy and financial data. The income capitalization approach to building appraisal is adopted as a model for linking sustainability to value through net operating income. The results suggest that retrofitting buildings can decrease operating costs, increase occupancy rates, and increase effective rent (rental revenue), thereby increasing net operating income. These benefits are not necessarily achieved in every retrofit; however where these benefits do occur, they have positive effects on value.
\end{abstract}




\section{Acknowledgements}

There are many people I would like to sincerely thank for their support in my research.

UNIVERSITY OF TORONTO

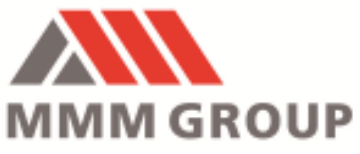

BOMA.
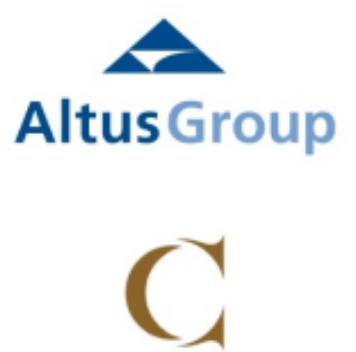

CONESTOGA

Connect Life and Learning
First and foremost, I would like to thank my research supervisor, Professor

Kim Pressnail, for affording me the opportunity to work on a project I truly enjoyed and for his support and guidance. I would also like to thank Daniel Calero who, during his time as an undergraduate student, assisted me greatly particularly with the financial analysis aspects of this project.

I am also very grateful for the support of Maurice Safatly of MMM Group. This project was funded in part by MMM group and while working for Maurice I gained not only valuable data for this project but also valuable experience in the energy consulting industry. I would also like to thank my colleagues at MMM for enriching my experience.

Energy data and retrofit details were provided by BOMA Canada. I would like to thank in particular Hazel Sutton for her ongoing collaboration with me.

Financial data was provided by Altus Group. I would like to thank Richard Clift for the procurement of this invaluable data and for his insight.

Thanks also to Alita Jones, who was a big help with my case studies through her previous work at Conestoga College and who also tapped into her wide network to put me in contact with others that could help me in this pursuit.

Finally, I would like to thank my friends and family for their ongoing support through my time spent working on this thesis. Thanks especially to my father, from whom I inherited my desire for lifelong learning.

Value Impacts of Energy Efficiency Retrofits on Commercial Office Buildings in Toronto, Canada | iii 


\section{Contents}

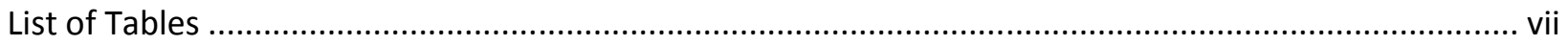

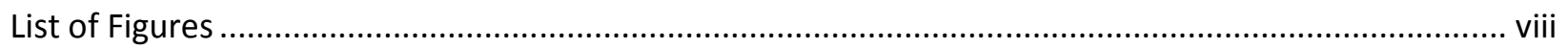

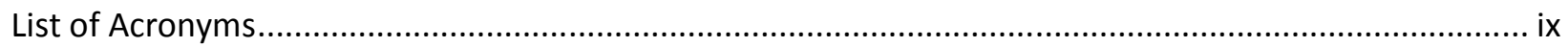

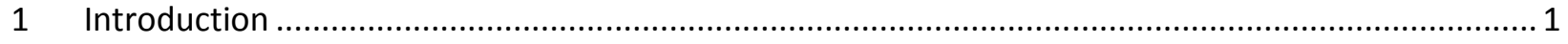

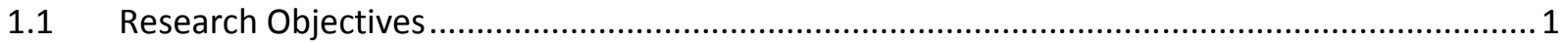

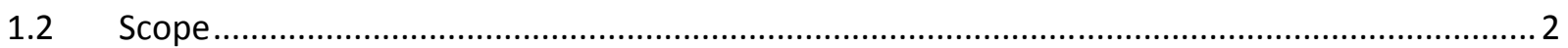

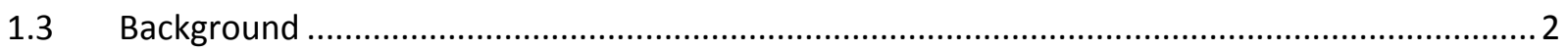

1.3.1 Profile of Canada's Existing Commercial Office Building Stock .......................................... 4

1.4 Defining "Sustainable Building" and Building Rating Systems ................................................. 6

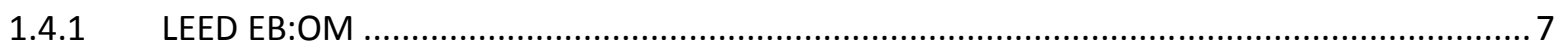

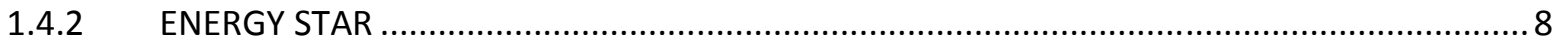

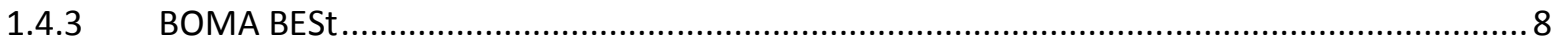

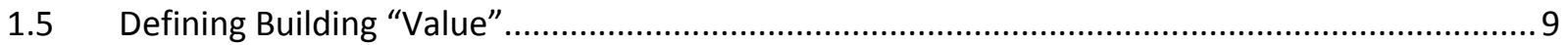

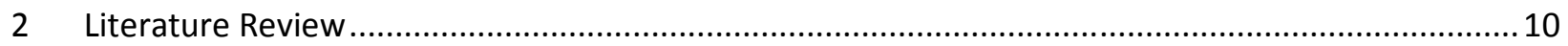

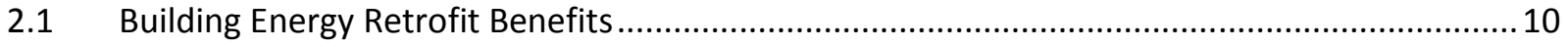

2.1.1 Benefit 1 - Lower Operating Costs ….......................................................................... 11

2.1.2 Benefit 2 - Improved Building Quality ............................................................................ 11

2.1.3 Benefit 3 - Reputational Benefits ................................................................................. 12

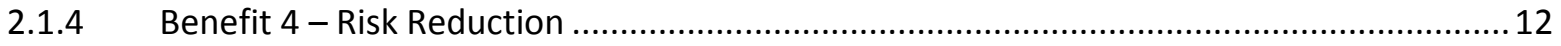

2.1.5 Benefit 5 - Tenant Retention and Productivity .......................................................... 13

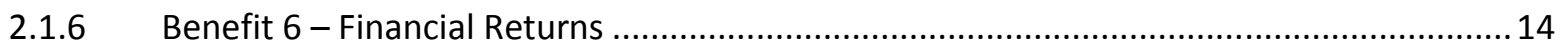

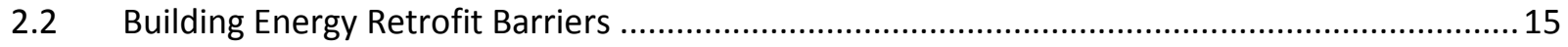

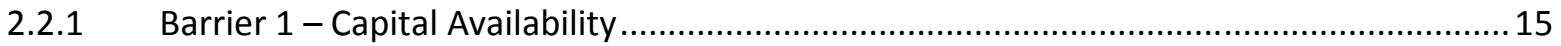

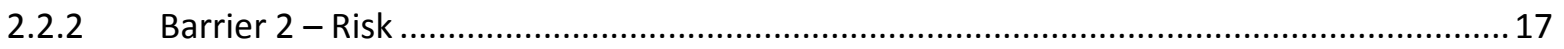

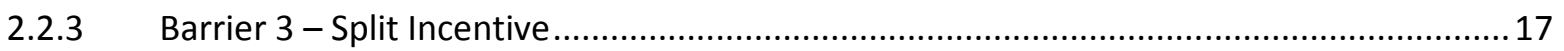

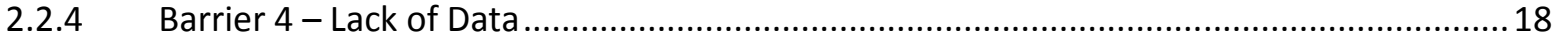

2.2.5 Barrier 5 - Lack of Mechanism for Sustainable Feature Valuation................................... 19

2.2.6 Barrier 6 - Lack of Energy Policy Implementation .......................................................... 19

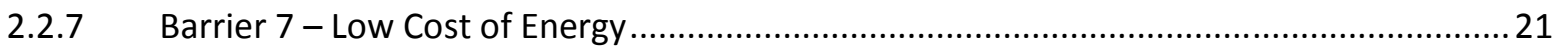

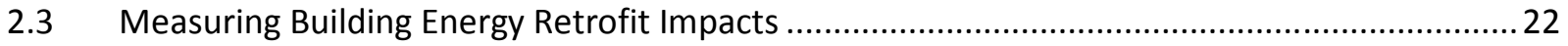




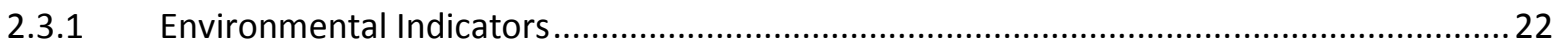

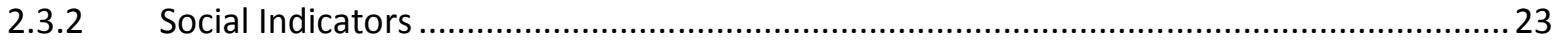

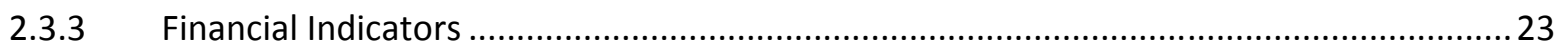

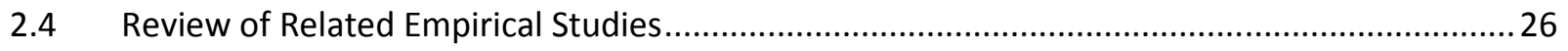

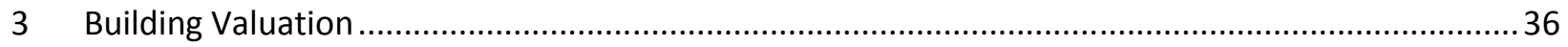

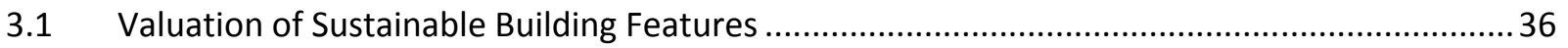

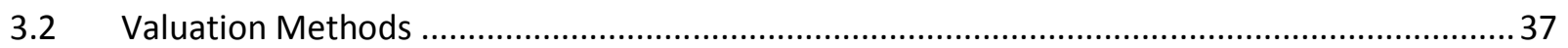

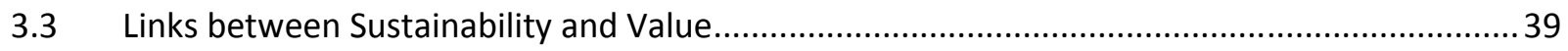

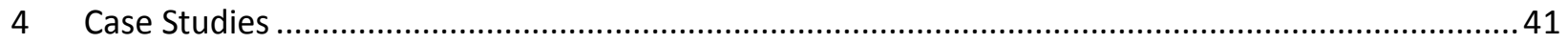

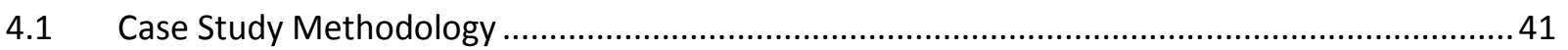

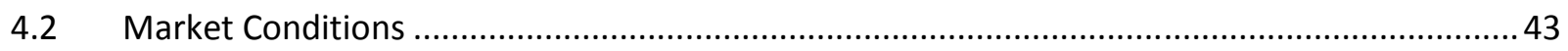

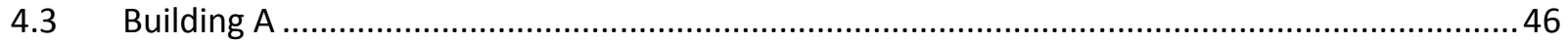

4.3.1 Building A Retrofit Description ……............................................................................ 46

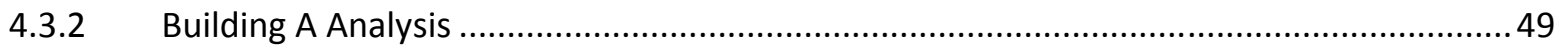

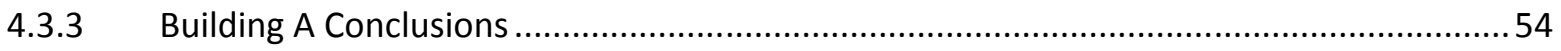

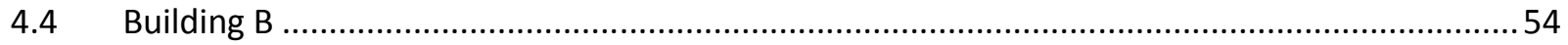

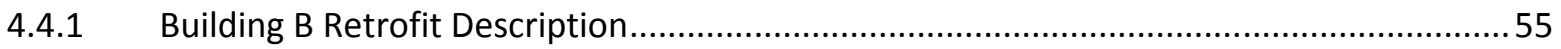

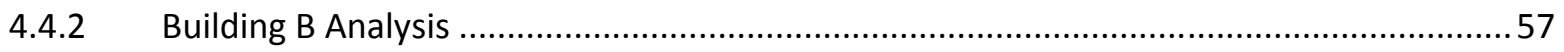

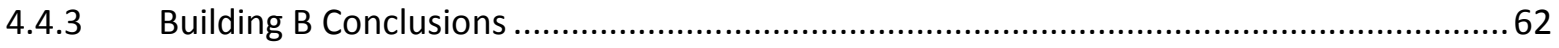

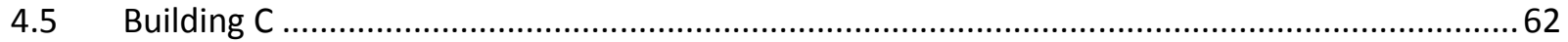

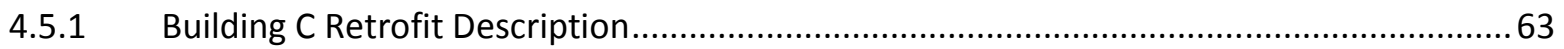

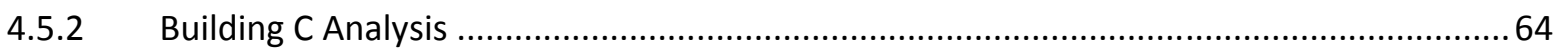

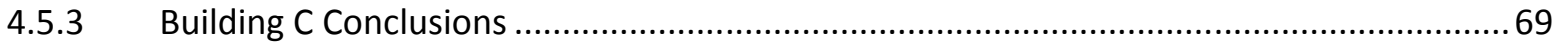

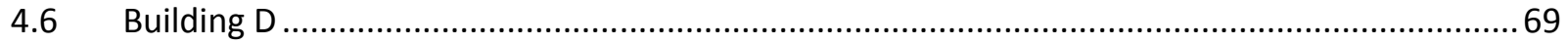

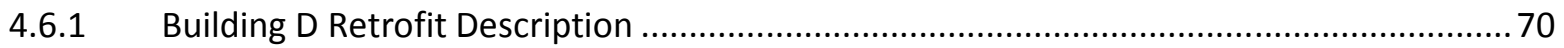

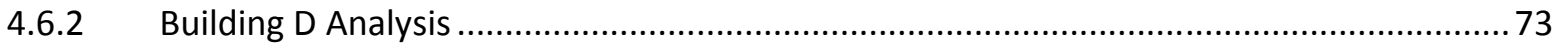

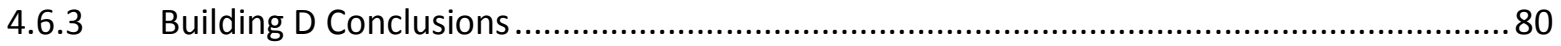

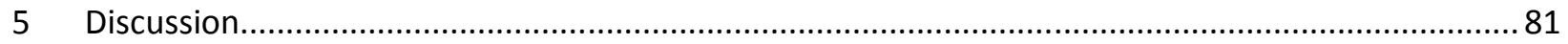

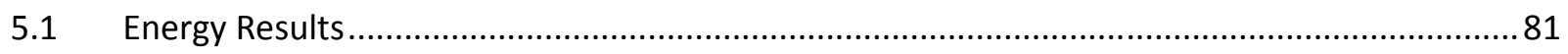

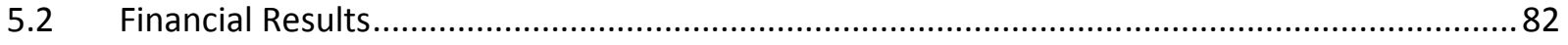

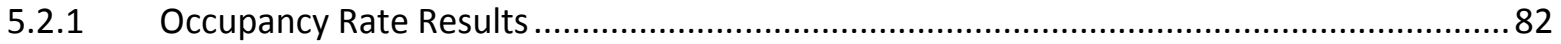




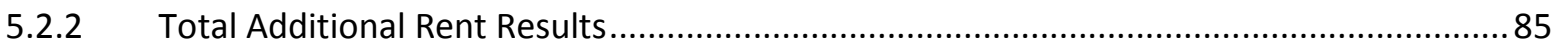

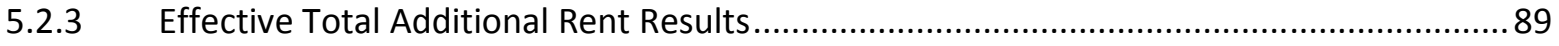

5.2.4 Results Comparison to Related Empirical Studies ......................................................... 92

5.2.5 The Relationship between Effective Rent and Building Value .........................................93

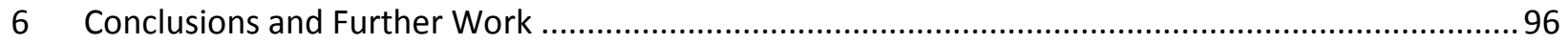

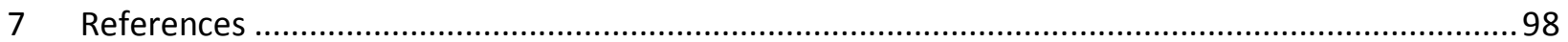

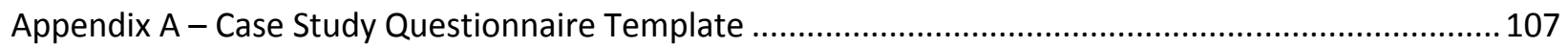

Appendix B - Case Study Raw Data and Calculations................................................................... 111 


\section{List of Tables}

Table 1-1 - Canadian Office Building Retrofit Inventory .................................................................. 6

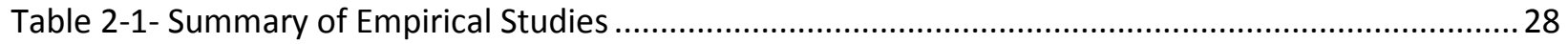

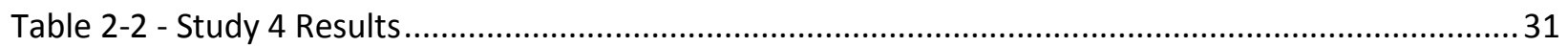

Table 3-1 - Links Between Sustainable Building Features and Value .................................................... 40

Table 4-1 - Downtown Toronto Office Building Market Average Rental Rates ....................................... 45

Table 4-2 - Building A Retrofit Energy Savings Compared to 2009 Baseline ............................................50

Table 4-3 - Building A Financial Data Summary ….............................................................................. 50

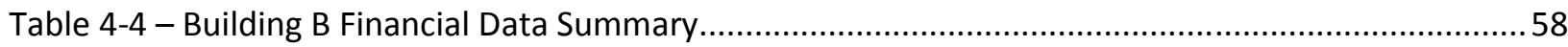

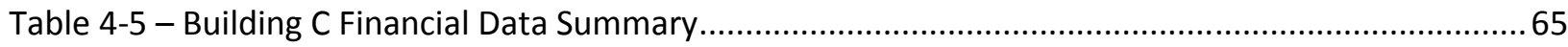

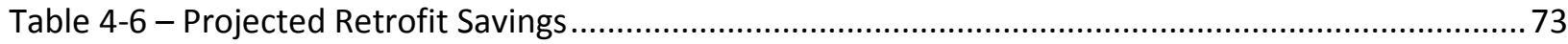

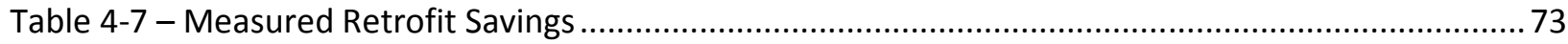

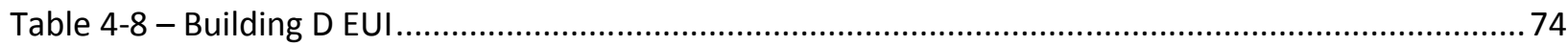

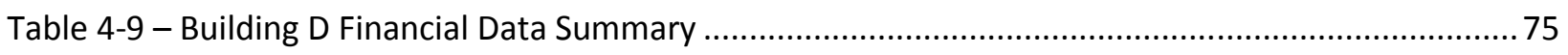

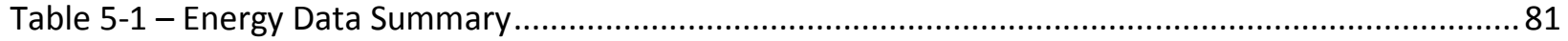




\section{List of Figures}

Figure 1-1 - Canada's Historical GHG Emissions and Projections ....................................................... 3

Figure 1-2 - Energy Intensity and Number Built by Building Age (Canadian Commercial Sector)............... 5

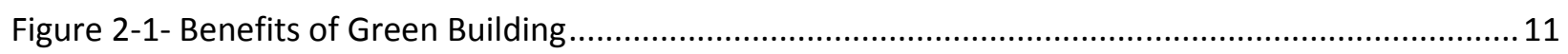

Figure 2-2 - Greatest Obstacles to Building Energy Efficiency Investment............................................. 15

Figure 2-3 - Financial Obstacles to Improving Building Energy Efficiency ............................................... 16

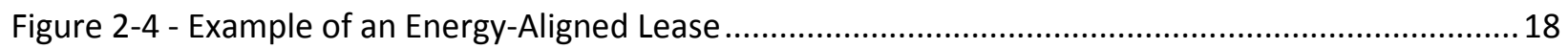

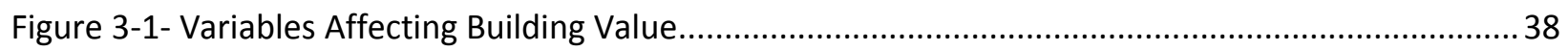

Figure 4-1 - Toronto Market Trend for Office Building Occupancy Rate .............................................. 44

Figure 4-2 - Toronto Office Market Average Monthly Rents ............................................................... 45

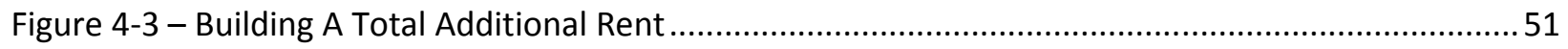

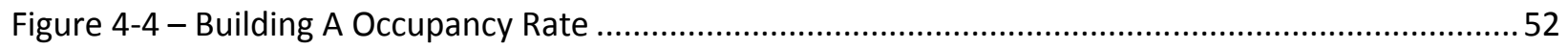

Figure 4-5 - Building A Effective Total Additional Rent ..................................................................5

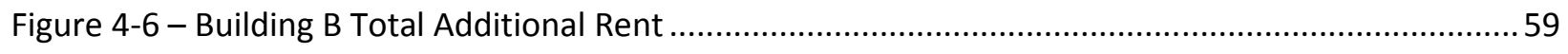

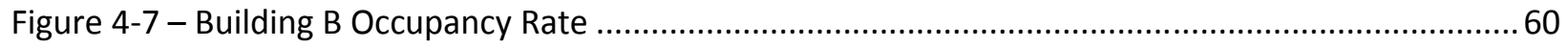

Figure 4-8 - Building B Effective Total Additional Rent ................................................................... 61

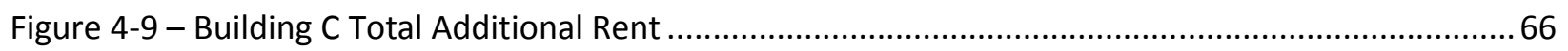

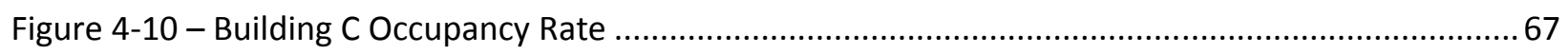

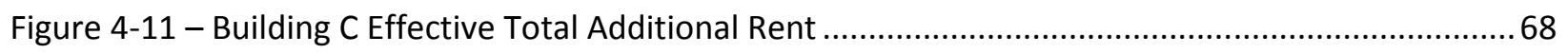

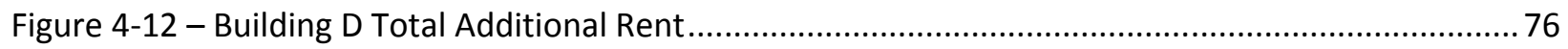

Figure 4-13 - Annual Total Additional Rent and IESO Electricity Price Increases....................................77

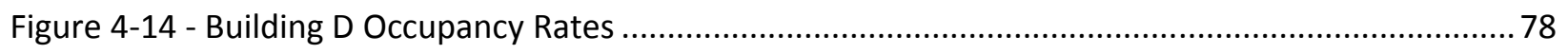

Figure 4-15 - Building D Effective Total Additional Rent ..................................................................... 79

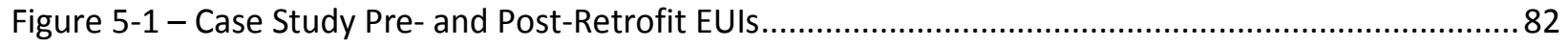

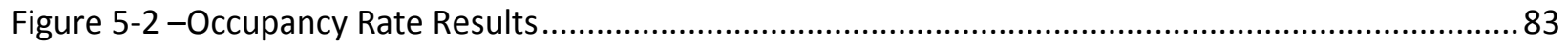

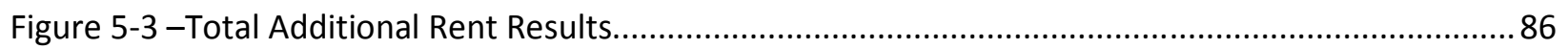

Figure 5-4 -Total Additional Rent Results for Buildings A, B, and C Only........................................... 87

Figure 5-5 -Effective Total Additional Rent Results............................................................................90 


\section{List of Acronyms}

\begin{tabular}{|c|c|}
\hline AHU & Air Handling Unit \\
\hline BAS & Building Automation System \\
\hline BOMA BESt & Building Owner and Managers Association Building Environmental Standards \\
\hline BTU & British Thermal Unit \\
\hline CaGBC & Canada Green Building Council \\
\hline CCE & Cost of Conserved Energy \\
\hline CFC & Chlorofluorocarbon \\
\hline CFL & Compact Fluorescent Lightbulb \\
\hline $\mathrm{CO}_{2}$ & Carbon Dioxide \\
\hline CSR & Corporate Social Responsibility \\
\hline CUSPAP & Canadian Uniform Standards of Professional Appraisal Practice \\
\hline DDC & Direct Digital Control \\
\hline DHW & Domestic Hot Water \\
\hline ekWh & Equivalent Kilowatt-Hours \\
\hline EPA & Environmental Protection Agency \\
\hline ESCO & Energy Service Company \\
\hline EUI & Energy Use Intensity \\
\hline GHG & Greenhouse Gas \\
\hline GJ & Gigajoule (One Billion Joules) \\
\hline GPM & U.S. Gallons Per Minute \\
\hline GTA & Greater Toronto Area \\
\hline HCFC & Hydrochlorofluorocarbon \\
\hline HVAC & Heating, Ventilation and Air Conditioning \\
\hline IESO & Ontario's Independent Electricity System Operator \\
\hline IGU & Insulated Glass Units \\
\hline LCCA & Life Cycle Cost Analysis \\
\hline LED & Light-Emitting Diode \\
\hline LEED & Leadership in Energy and Environmental Design \\
\hline LEED EB:OM & LEED for Existing Buildings: Operations and Maintenance \\
\hline
\end{tabular}




$\begin{array}{ll}\text { low-e } & \text { Low-Emissivity } \\ \text { MBTU } & \text { One Thousand British Thermal Units } \\ \text { MNECB } & \text { Model National Energy Code for Buildings } \\ \text { NCREIF } & \text { National Council of Real Estate Fiduciaries } \\ \text { nd } & \text { no data } \\ \text { NOI } & \text { Net Operating Income (revenue minus expenses) } \\ \text { NPV } & \text { Net Present Value } \\ \text { NRCan } & \text { Natural Resources Canada } \\ \text { NRTEE } & \text { Canada's National Round Table on the Environment and the Economy } \\ \text { O\&M } & \text { Operation and Maintenance } \\ \text { OBC } & \text { Ontario's Building Code Act } \\ \text { OEB } & \text { Ontario Energy Board } \\ \text { OEXP } & \text { Building expenses other than operation and maintenance costs and taxes } \\ \text { REALpac } & \text { Real Property Association of Canada } \\ \text { ROI } & \text { Return On Investment } \\ \text { TAF } & \text { Toronto Atmospheric Fund } \\ \text { tCO } & \text { Carbon dioxide equivalent tonnes (GHG measure) } \\ \text { VAV } & \text { Variable Air Volume } \\ \text { VFD } & \text { Variable Frequency Drive }\end{array}$




\section{Introduction}

This study presents an analysis of the asset value impacts of sustainability retrofits on commercial office buildings with the goal of strengthening the business case for sustainable building in Canada.

This thesis is divided in the following manner: first, context is provided through an examination of the current state of existing commercial office buildings in Canada and their energy implications. Second, the concepts of a "sustainable building" and "building value" are discussed in broad terms. Thirdly, an in-depth review of existing literature including summaries of related empirical studies is presented. Then, four case studies are analyzed and are discussed both individually and all together. Finally, conclusions are made and further research opportunities are identified.

The referencing style chosen was IEEE, which is an in-text citation referring to a bibliographical entry. References are numbered in the same order as they appear in the text. Each bibliographical entry is represented by only one number which may recur in the text. This style was chosen because this thesis references many documents and several statements reference multiple documents.

\subsection{Research Objectives}

The objective of this thesis is to analyze the relationship between commercial office building energy retrofits and building value for Canadian buildings. This is accomplished through detailed examination of four case studies with energy and financial data before and after retrofit occurrence. The results are compared to related empirical studies that were performed using U.S. data to determine whether Canadian office buildings can achieve the same value benefits through retrofitting.

The findings of this research are intended to provide insight into financial benefits of retrofitting existing commercial office buildings beyond simple payback and net present value type calculations. Asset value is another financial tool that improves the investor decision-making process. Showing through empirical, qualitative research that existing building asset value could increase as a result of energy retrofits would contribute to the business case for buildings that are more sustainable.

Civil Engineering UNIVERSITY OF TORONTO
Value Impacts of Energy Efficiency Retrofits on Commercial Office Buildings in Toronto, Canada | 1 


\subsection{Scope}

The scope of the financial analysis in thesis was factors affecting the value of recently retrofitted Canadian commercial office buildings. The existing Canadian commercial office building stock and Canadian environmental goals are presented in the following section.

All of the case studies that were analyzed herein are located in downtown Toronto, Ontario due to data limitations. Therefore the geographical scope of this study, which was originally intended to be nationwide, was narrowed to Toronto in Section 4.

\subsection{Background}

Sustainable building is a growing practice in Canada as the environmental and health benefits become increasingly apparent and as the challenges of dwindling conventional oil supplies and global warming have become issues the general public wants addressed. $91 \%$ of Canadians today are concerned about global warming and $89 \%$ support immediate action [1]. Further employees are increasingly making professional decisions based on corporate ethics and social responsibility [1].

In 2009, Canada set a target under the Copenhagen Accord to reduce greenhouse gas (GHG) emissions by $17 \%$ from 2005 levels by the year 2020, reducing total GHG emission to 611 megatonnes (Mt) annually $[2,3]$. Commitment to this target was part of a global climate change movement of the United Nations. Canada's Emission Trends published in 2013 show that although GHG levels are being reduced, there is a significant gap between actual progress and the target (Figure 1-1).

Civil Engineering
Value Impacts of Energy Efficiency Retrofits on Commercial Office Buildings in Toronto, Canada | 2 


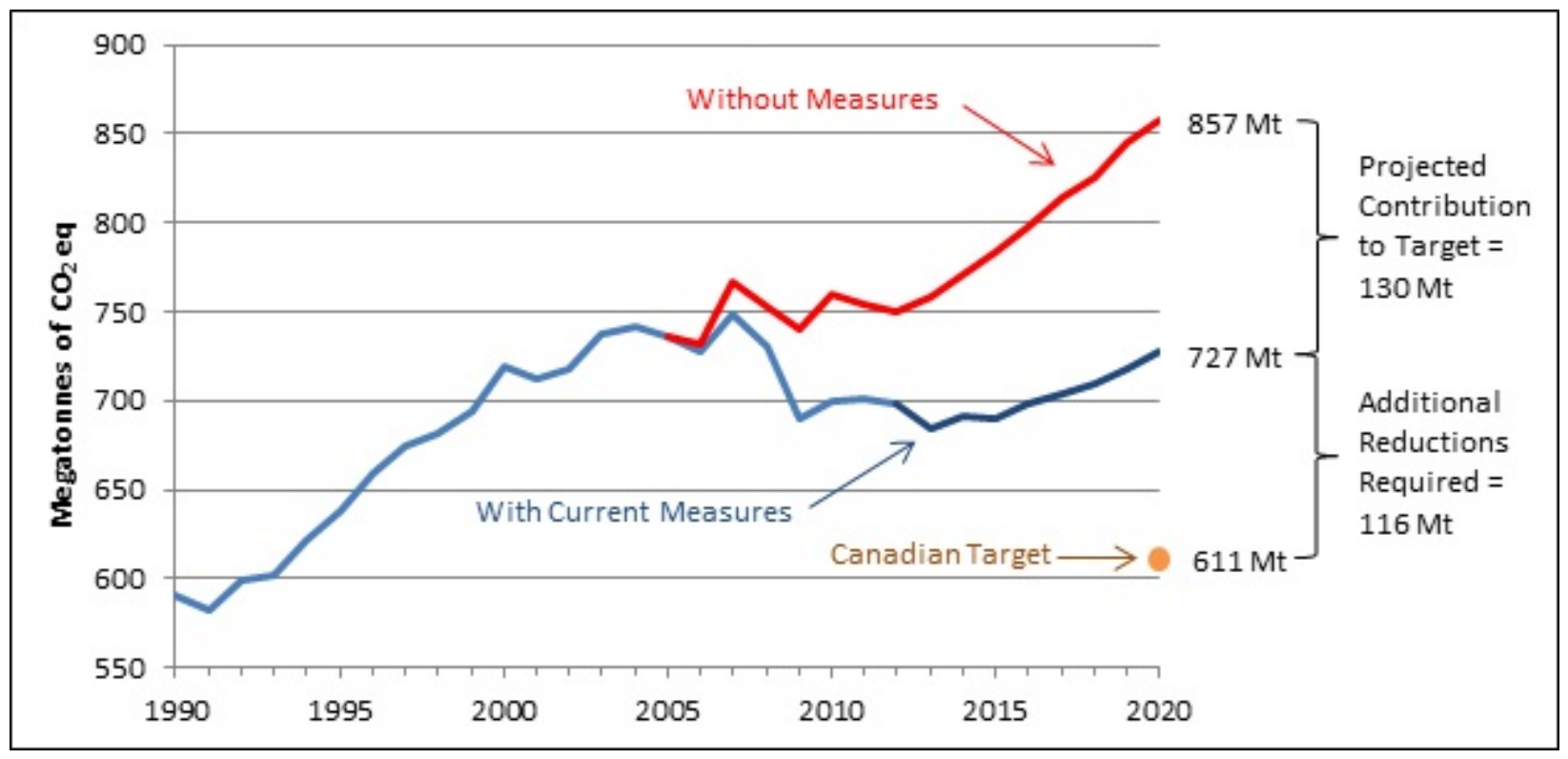

Figure 1-1 - Canada's Historical GHG Emissions and Projections [4]

It is projected that Canada will emit 116 Mt more GHGs by the year 2020 than its Copenhagen Accord target. Projected at 727 Mt, Canada's 2020 GHG emissions will be 130 Mt lower than if no action had been taken; however, the 2020 projection is only approximately about 9 Mt of GHGs below 2005 levels (a $1.2 \%$ reduction). This level of GHG emissions suggests that Canadian energy efficiency investment is lacking. Energy consumption in buildings is a substantial part Canada's energy future and must be addressed.

New, green buildings with innovative sustainability features are entering the marketplace in response to an increasingly apparent need to not only conserve resources and reduce GHG emissions but also to reduce building energy consumption costs and improve tenant health. Commercial office building owners, recognizing that sustainability and conservation measures do, in fact, save costs over a building's life cycle, are investing in green design for their building projects. But what about existing buildings? As of 2009 , over $80 \%$ of Canadian office buildings were at least a decade old and this type of building consumes more energy per unit area than any other type of commercial building $[5,6]$.

Since 2009 the existing office building stock has only grown. These aging buildings are energy and water sinks. However, studies have shown that environmental savings from building re-use are between $4 \%$ and $46 \%$ over building new when comparing buildings with the same level of energy performance, resulting in a higher return on investment [7]. 
Why, then, has there not been a focus on applying sustainability principles to Canada's existing building stock, which is significantly larger than the new construction sector? Existing buildings present a huge opportunity to contribute towards Canada's energy and environmental goals. However, based on the current lack of investment in building sustainability retrofits, it appears that building owners/investors do not perceive there to be enough financial value in undertaking these projects. This perception is based on a lack of evidence of the value of existing building retrofits. Value is recognized in the financial community when it is reflected by data; empirical evidence will be required before the financial implications of building retrofits are widely accepted [8].

\subsubsection{Profile of Canada's Existing Commercial Office Building Stock}

Buildings account for approximately $31 \%$ of the energy consumed in Canada [9]. The commercial and institutional building sector in particular accounts for $12.5 \%$ of Canadian energy use and $11 \%$ of Canadian greenhouse gas emissions $[10,11]$. These significant proportions offer opportunities for reductions in environmental impact and, for building owners, reduction in energy costs.

Natural Resources Canada's (NRCan) 2009 Survey of Commercial and Institutional Energy Use determined that there were approximately 83,500 non-medical commercial office buildings in Canada covering 147.5 million square metres of floor space having an average annual energy use intensity (EUI) of $1.20 \mathrm{GJ} / \mathrm{m}^{2}$ (333 ekWh/m $\mathrm{m}^{2}$ ) [5]. The following figure shows energy intensity by decade for the Canadian commercial building sector.

Civil Engineering UNIVERSITY OF TORONTO
Value Impacts of Energy Efficiency Retrofits on Commercial Office Buildings in Toronto, Canada | 4 


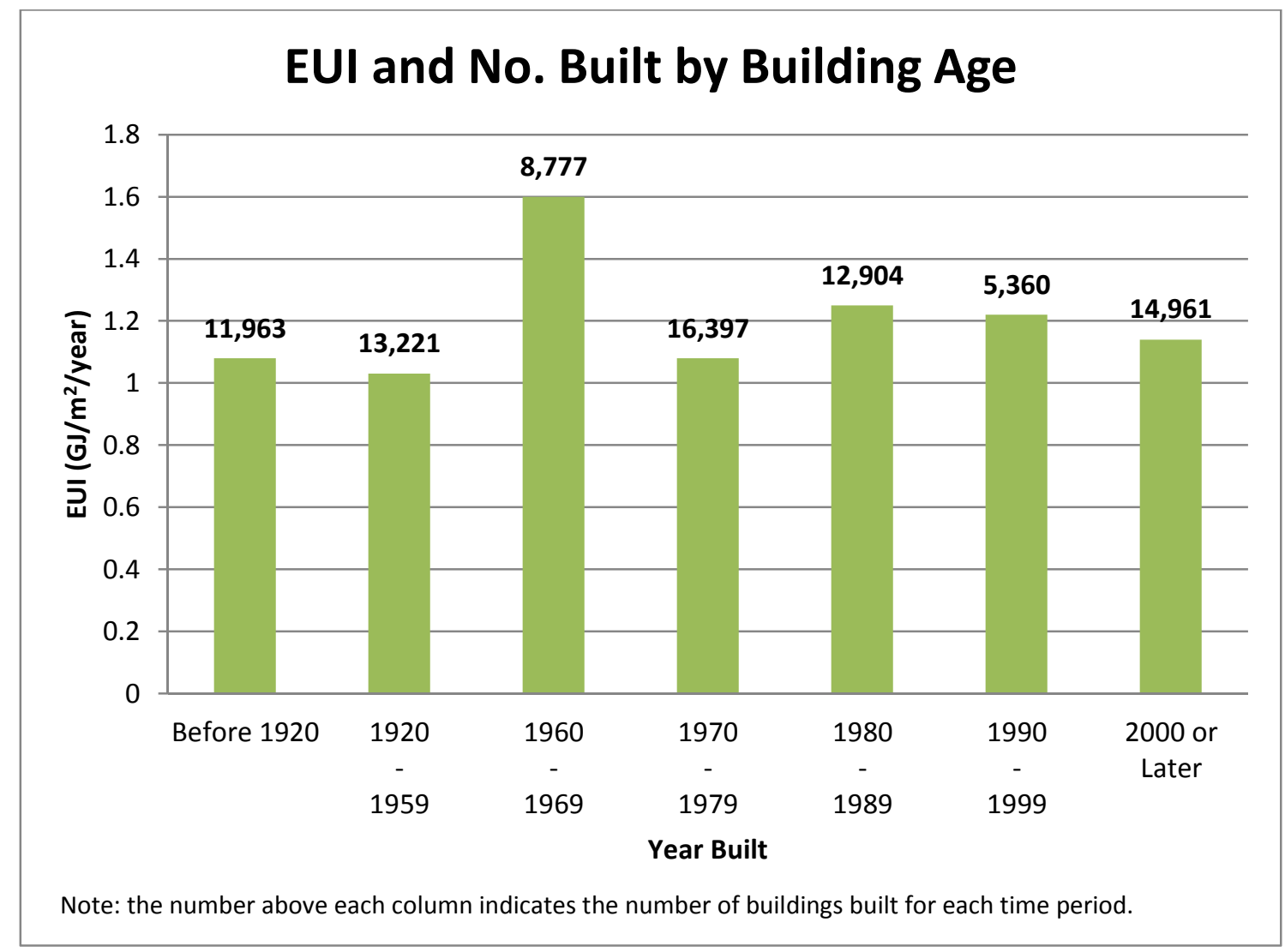

Figure 1-2 - Energy Intensity and Number Built by Building Age (Canadian Commercial Sector) [5, 12]

This figure reveals that:

- over $80 \%$ of Canada's non-medical office buildings were constructed before the year 2000;

- overall energy use intensity has been declining slightly since the 1980s;

- a large number of buildings in this sector could benefit from energy retrofits, particularly those built in the 1960s.

The following table summarizes retrofits in the Canadian commercial office building sector, excluding medical buildings. 
Table 1-1 - Canadian Office Building Retrofit Inventory [5]

\begin{tabular}{|c|c|c|c|c|c|c|c|}
\hline \multirow[b]{2}{*}{$\begin{array}{l}\text { Primary } \\
\text { Activity }\end{array}$} & \multirow[b]{2}{*}{ Type of Renovation } & \multicolumn{2}{|l|}{ Buildings } & $\begin{array}{c}\text { Share of } \\
\text { Total } \\
\text { Buildings }\end{array}$ & \multicolumn{2}{|c|}{ Floor Space } & $\begin{array}{l}\text { Share of } \\
\text { Total Floor } \\
\text { Space }\end{array}$ \\
\hline & & \multicolumn{3}{|c|}{ Q.I. } & $\begin{array}{l}\text { (millions } \\
\text { of } \mathrm{m}^{2} \text { ) }\end{array}$ & Q.I. & \\
\hline \multirow{9}{*}{$\begin{array}{l}\text { Office building } \\
\text { (non-medical) }\end{array}$} & Total & 83583 & $A$ & & 147.5 & A & \\
\hline & No renovation & 47762 & $A$ & $57.1 \%$ & 57.5 & A & $39.0 \%$ \\
\hline & Any type of renovation & 35820 & $A$ & $42.9 \%$ & 90 & B & $61.0 \%$ \\
\hline & Space heating & 16160 & B & $19.3 \%$ & 59.1 & $\mathrm{C}$ & $40.1 \%$ \\
\hline & Space cooling & 14201 & B & $17.0 \%$ & 38.6 & A & $26.2 \%$ \\
\hline & Lighting & 23129 & B & $27.7 \%$ & 48.7 & A & $33.0 \%$ \\
\hline & Windows/insulation & 17308 & B & $20.7 \%$ & 24.2 & B & $16.4 \%$ \\
\hline & Additions/reductions & - & $\mathrm{F}$ & - & - & $\mathrm{F}$ & - \\
\hline & Other & 18256 & B & $21.8 \%$ & 30.3 & $\mathrm{~B}$ & $20.5 \%$ \\
\hline
\end{tabular}

${ }^{*} Q$.I. indicates quality of information, with $\mathrm{A}$ being the highest.

As of 2009 , approximately $57 \%$ of Canadian office buildings had not undergone any sort of retrofit.

Assuming all retrofits occurred in older buildings, i.e. buildings constructed before the year 2000, nearly half of Canadian commercial office buildings more than a decade old had not undergone any type of renovation as of 2009. This perspective of the Canadian commercial office building sector again highlights the market for energy retrofits and the profound impact such retrofits could have on the environment.

\subsection{Defining "Sustainable Building" and Building Rating Systems}

The definition of a "sustainable" building is one of great importance to the subject of building energy retrofits as these types of retrofits typically aim to take an older building and transform it into one that is "sustainable". In 1987, the United Nations adopted the Vancouver Valuation Accord/Brundtland Commission definition of sustainable development: "development that meets the needs of the present without compromising the ability of future generations to meet their own needs" [8]. Sustainability is a harmony of three components: environmental concerns, social concerns, and financial concerns. This concept, called the "triple bottom line", and its adoption has coincided with a significant market shift from traditional business strategy to a newer, more comprehensive approach.

Therefore, a "sustainable building" is a building that is designed, constructed, operated, and decommissioned such that environmental impacts are minimized, health and safety are optimized, and financial gains are made over the long-term (e.g. costs are reduced). Retrofitting existing buildings can 
reduce negative environmental impacts of a building by improving energy and water efficiency, reducing waste, and improving building operations. Building retrofits can improve social conditions by improving tenants' perceptions of their surroundings and by removing health-adverse products and materials (e.g. toxic cleaning supplies, paints, etc.). There is evidence that, for office buildings, healthier buildings lead to increased productivity and reduced absenteeism thereby improving tenant profitability [13]. Essentially, improving environmental conditions positively impacts social conditions, which in turn increases building profitability. Sustainable buildings also have lower operating costs through reduced consumption and waste.

Green building rating systems have been developed and marketed by various organizations as tools to quantify and classify building sustainability. These tools can be used to compare similar buildings or to compare pre- and post-retrofit conditions. In Canada, the most widely-used tools for existing buildings are:

- LEED for Existing Buildings: Operations and Maintenance (LEED EB:OM);

- ENERGY STAR; and

- Building Owners and Managers Association Building Environmental Standards (BOMA BESt).

These tools are discussed in more detail next. Each of these building certification mechanisms classifies a building in a way the building industry and general public can quickly and easily understand.

\subsubsection{LEED EB:OM}

The LEED EB:OM rating system was developed and is administered by the Canada Green Building Council (CaGBC). The intent of the LEED EB:OM rating system is to "promote high-performance, healthful, durable, affordable, and environmentally sound practices in existing buildings" [14]. LEED green building rating systems in general are widely adopted in Canada and are seen as the standard for quality, high-performance green buildings [15]. As of summer 2014, 349 commercial office buildings have been certified under the LEED EB:OM system in Canada [15].

LEED EB:OM focuses mostly on energy and water conservation and site sustainability (particularly the promotion of transportation methods alternative to single passenger vehicles). This reflects the CaGBC's overall goal to reduce greenhouse gas emissions, energy use, and water use. The LEED EB:OM program requires recertification every 5 years to ensure continual sustainable performance. In general,

Civil Engineering UNIVERSITY OF TORONTO
Value Impacts of Energy Efficiency Retrofits on Commercial Office Buildings in Toronto, Canada | 7 
LEED rating systems are perceived to be fairly complex as they are composed of many points and require in-depth documentation and third-party review.

\subsubsection{ENERGY STAR}

ENERGY STAR is a voluntary program developed and administered by the U.S. Environmental Protection Agency (EPA) [16]. The ENERGY STAR program certifies energy efficient products and buildings. The U.S. EPA developed the Portfolio Manager tool to facilitate ENERGY STAR certification for buildings; this free online tool can track and measure energy and water consumption and greenhouse gas emissions for buildings. The ENERGY STAR score is a percentile ranking of a building's EUI against similar buildings in similar climatic regions. Therefore, this label is indicative of building energy use only and does not incorporate other aspects of sustainability. A building must achieve a score of 75 or higher (i.e. be in the top quartile) to be labeled an ENERGY STAR certified building. This percentile scale necessitates continual improvement of buildings and building technology in order to maintain an ENERGY STAR score and thus to keep the ENERGY STAR certification.

A Canadian version of the ENERGY STAR Portfolio Manager tool was released mid-2013 and as of summer 2014 is only available for commercial office buildings and K-12 schools [17]; more building types will be added over time. NRCan supports the use of ENERGY STAR Portfolio Manager as a national energy benchmarking tool. As of May 2014, approximately 4,000 buildings in Canada have been registered in Portfolio Manager [18]. ENERGY STAR is more widespread in the U.S., where over 260,000 buildings are registered in Portfolio Manager including nearly $40 \%$ of the U.S. commercial buildings market $[18,19]$. NRCan intends to follow the U.S. model in building benchmarking with the Canadian version of ENERGY STAR Portfolio Manager.

\subsubsection{BOMA BESt}

BOMA BESt is administered by BOMA Canada, an organization which concerns itself with representing its members and supporting the Canadian commercial building sector activity while promoting environmental stewardship [20]. The main objective of its BESt rating system is to encourage continuous improvement of building operation and maintenance [21]. BOMA BESt puts focus on energy conservation, emission and effluent reduction, and indoor environment improvement. As of the Fall 2014, over 1,700 Canadian buildings have achieved a BOMA BESt certification. Buildings must re-certify every 3 years.

Civil Engineering UNIVERSITY OF TORONTO
Value Impacts of Energy Efficiency Retrofits on Commercial Office Buildings in Toronto, Canada $\mid 8$ 
The BOMA BESt green building rating system was designed for flexible and simple implementation by building owners and staff. Most of the certification process is completed online and does not require the hiring of consultants to manage complex documentation and calculations. Critics of BOMA BESt contend, however, that these simple and flexible requirements weaken the rating system and provide little motivation for building owners and operators to exceed the minimum requirements that are less rigorous than those of the LEED system.

\subsection{Defining Building "Value"}

A clear definition of building asset value is critical for determining the relationship between building sustainability and value. The term "value" generally refers to a market's view of the benefits accrued by the owner of some good or service [22]. This is not necessarily the same as price since price paid for a good or service reflects the interest level of the buyer and not of the whole market. Value is also different from worth; worth refers to the owner's view of the benefits accrued through ownership of its own goods/services [22].

Building value in Canada is determined through the process of professional valuation or appraisal. The goal of an appraisal is to "issue a well-founded prognosis of a property's selling price for a hypothetical property transaction on a particular date... in other words, to ascribe a value to a building without knowing if the free market would accept this estimate" [22]. 


\section{Literature Review}

The following sections summarize the existing literature on the relationship between building energy efficiency (particularly through retrofitting existing buildings) and building value. Both qualitative and quantitative studies have been included. The review also facilitated the identification of gaps in the literature that this study intends to address.

\subsection{Building Energy Retrofit Benefits}

Energy-retrofitting buildings increases overall building sustainability and can create benefits for owners, tenants, and the public. Many qualitative studies have been conducted to determine what factors contribute to building owners'/tenants' perceptions of the value of building sustainability. In general, participants in the studies recognized the growing demand for sustainable buildings and had the expectation that this growth would continue [23, 24]. All of these studies examined the perspectives of building owners and tenants who have already chosen to value sustainability in their choice of building; therefore there is an inherent bias towards sustainability that portrays sustainable buildings in a positive light.

In 2014, McGraw Hill Construction conducted a survey with 200 respondents across Canada including architects, contractors, building owners, developers, and engineers to analyze trends in the Canadian sustainable building market [25]. One of the study's findings was greater perceived benefits of green buildings compared to conventional buildings. Figure 2-1 shows the results by percentage of respondents who perceived a certain benefit of green building to be "important" (vs "not important"); for example, $80 \%$ of respondents said lower operating costs was an important benefit.

Civil Engineering UNIVERSITY OF TORONTO
Value Impacts of Energy Efficiency Retrofits on Commercial Office Buildings in Toronto, Canada | 10 


\section{Green Building Benefits Deemed "Important"}

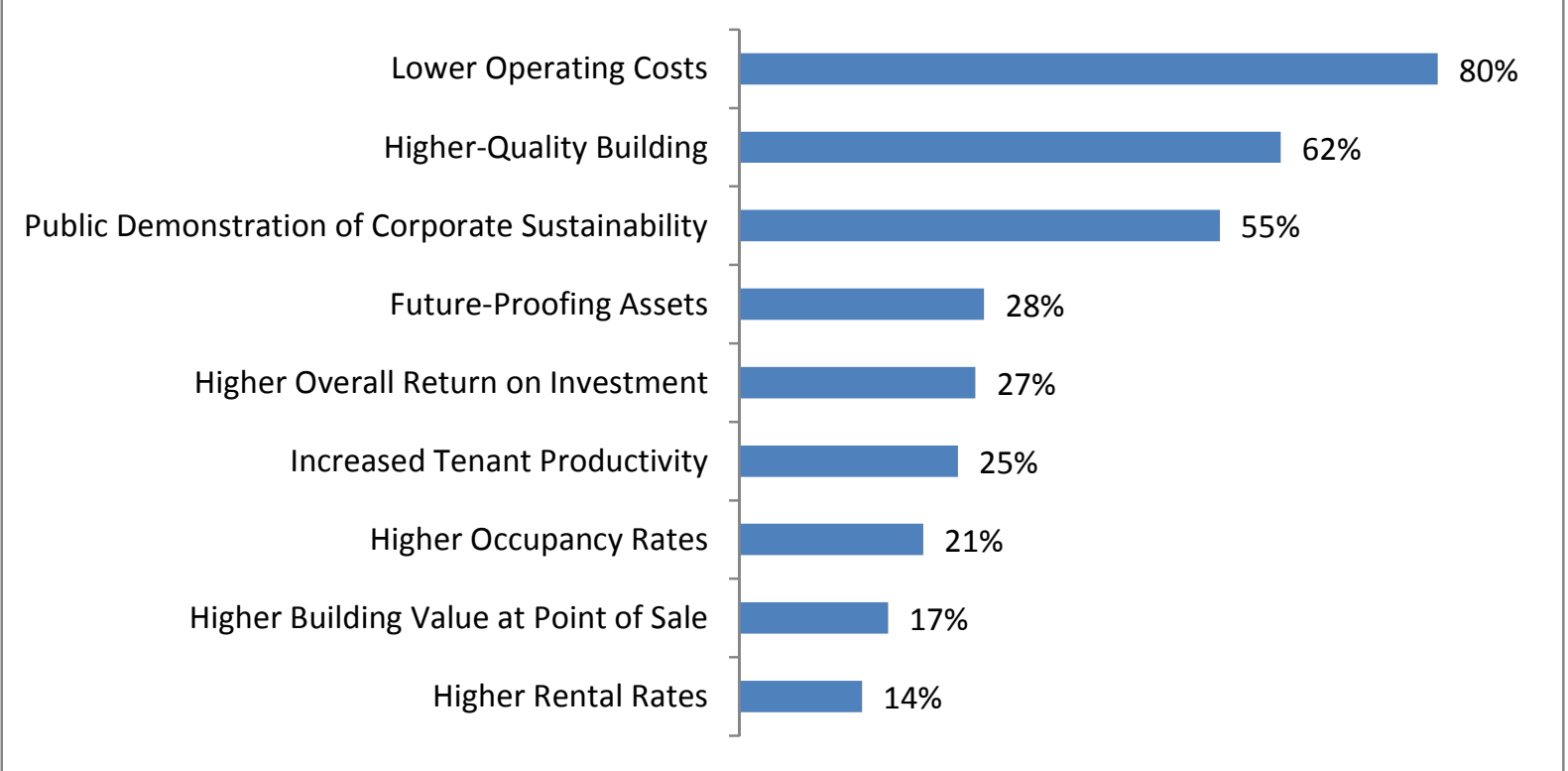

Figure 2-1- Benefits of Green Building (Adapted from [25])

A summary of these and other benefits of green buildings, particularly retrofitted buildings, is discussed in the following sections.

\subsubsection{Benefit 1 - Lower Operating Costs}

The most intuitively understood benefit of green buildings is lower operating costs through resource efficiency. Operational and maintenance requirement reductions that generally accompany increases in building sustainability also decrease costs $[26,23]$. Retrofitting to implement energy conservation measures can substantially decrease energy use and therefore utility costs and overall operating expenses. Energy retrofits typically reduce overall consumption by $20 \%$ to $30 \%$ [6, 27]. Energy represents approximately one third of operating expenses in a typical office building, making it the largest and most manageable operating expense for office space provision [28]. Decreasing these costs adds value for the building owners and, in the case of submetered buildings, for the tenants.

\subsubsection{Benefit 2 - Improved Building Quality}

Green buildings are perceived to be higher-quality buildings than their conventional counterparts. The association of quality with sustainability may be related to the increasing expectation that high-end office and residential buildings will be built (or retrofitted) sustainably [25]. As Canadians continue to

Civil Engineering UNIVERSITY OF TORONTO
Value Impacts of Energy Efficiency Retrofits on Commercial Office Buildings in Toronto, Canada | 11 
place more and more importance on sustainability, energy efficiency and waste reduction will become considerations in the determination of quality.

\subsubsection{Benefit 3 - Reputational Benefits}

Corporate social responsibility (CSR) is frequently reported to be of high importance in the building industry and to corporations in general $[28,26,29,23,30,31,27]$. CSR has become standard in North America and corporations that do not visibly and actively promote CSR are at a marketing and branding/reputational disadvantage. CSR describes firms' choices about processes, materials, and publicity including those related to treatment of employees and limitation of negative environmental impacts [27, 28]. A positive CSR image is perceived by building owners and tenants to attract investors, attract a better work force, and even to provide the ability to charge premium rents and/or selling prices $[28,23,32]$. Owning and/or occupying sustainable buildings can also contribute to a positive corporate image by portraying owners/occupants as technologically advanced and open to innovation [27].

Sustainability contributes positively to CSR as the public's environmental awareness spreads and the norm becomes environmental stewardship. Improved CSR can also help recruit employees, particularly from the younger generation, who were raised in an era of ever-increasing environmental concern and are believers in conservation [33]. A 2010 Real Property Association of Canada (REALpac) study found evidence that investing in well-managed CSR programs will can improve a corporation's reputation, cut costs, open new markets, lower risk, and improve management strategies [33]".

\subsubsection{Benefit 4-Risk Reduction}

"Future-proofing" refers to risk reduction for buildings. Conventional commercial buildings face several risks that can be mitigated through energy retrofitting and overall sustainable practice implementation.

1. Environmental risk: improved indoor environments typically accompany sustainable buildings. Improved indoor environment results in lower liability from issues such as indoor air quality and occupant health [6].

2. Risk of obsolescence: sustainable buildings are becoming more common and will become the standard in the near future. Non-sustainable buildings risk becoming devalued in the marketplace [6].

3. Risk of impending policy: as sustainable buildings become the norm and Canadians increasingly see the need to reduce GHG emissions, mandatory policy surrounding building energy use may

Civil Engineering UNIVERSITY OF TORONTO
Value Impacts of Energy Efficiency Retrofits on Commercial Office Buildings in Toronto, Canada | 12 
take root. Policy requiring minimum building performance will result in costly upgrades for underperformers.

4. Risk of fluctuating energy prices: reducing energy use will best position building owners and tenants to cope with future increases in energy prices from a financial standpoint [28, 34, 35]. The more energy efficient a building is, the smaller impact fluctuations in energy prices will have on owners and tenants [34]. The variability of energy costs is approximately the same as for the other revenue and expense categories for buildings, meaning reducing risks associated with energy price fluctuations should be considered at least as important as reducing other financial risks [27].

Reducing these risks, in theory, should lead to an improved risk profile for buildings and therefore lower insurance premia. Reduction of risk through sustainability is starting to gain recognition in the appraisal industry. In 2007, La Capitale General Insurance in Quebec announced that it would offer a 15\% discount on property insurance for LEED certified buildings [6]. Incorporating sustainability into building management allows building stakeholders to manage risks and invest responsibly.

\subsubsection{Benefit 5 - Tenant Retention and Productivity}

Another common perceived benefit of building sustainability is increased tenant productivity and retention $[26,23,30,24,28,32]$. Sustainable buildings are typically healthier buildings with improved indoor air quality, better lighting, and controllability of comfort systems. These features help to avoid "sick building syndrome", a condition of a building in which building occupants experience health and comfort issues that are linked to time spent in the building and not to any specific illness [36]. Sick building syndrome can result in decreased productivity and lower occupancy rates. Market studies have shown that the use of green building standards can increase building occupancy rates by $3 \%$ or more, and moving to a green building from a conventional building can increase productivity by $2 \%$ to $10 \%$ [ 37 , 38]. Employee salaries make up approximately $88 \%$ of commercial tenant costs while rent makes up only $9 \%$ and utilities and taxes makes up $1 \%$ each [35]. Therefore tenant productivity it is imperative.

More productive buildings with higher occupancy rates are more profitable. Thus, an outcome of sustainable building is increased profitability and for this reason sustainable buildings are attractive to owners and tenants alike.

Civil Engineering UNIVERSITY OF TORONTO
Value Impacts of Energy Efficiency Retrofits on Commercial Office Buildings in Toronto, Canada | 13 


\subsubsection{Benefit 6 - Financial Returns}

Higher return on investment, higher building value at point of sale, and higher rental rates are forms of financial returns achieved through sustainable investment in buildings. Higher return on investment was rated as an important benefit of green buildings by $27 \%$ of Canadian respondents [25]. Higher sale value and higher rental rates were rated as important by $17 \%$ and $14 \%$ of respondents, respectively [25]. These low ratings indicate that building investors are not convinced of the financial benefits of building and retrofitting sustainably. However, for owners and developers who recognize the financial benefits of building sustainability, the economic drivers for investments in sustainable buildings (particularly those with green labels) include: subsidies and tax benefits, reduced holding costs (lower vacancy rates and higher tenant retention), reduced building depreciation (linked to the use of the latest technologies), lower risk of income uncertainty, and ability to charge higher rents [29, 30, 28, 6, 32]. 


\subsection{Building Energy Retrofit Barriers}

The following sections outline barriers to building energy retrofits. These barriers discourage investment in sustainable retrofitting of commercial office buildings in Canada.

\subsubsection{Barrier 1 - Capital Availability}

Capital availability can be a significant barrier to energy retrofitting of commercial buildings. The 2013 Johnson Controls (Institute for Building Efficiency) Energy Efficiency Indicator Survey observed that lack of capital budget is the greatest obstacle facing North-American decision-makers considering building energy retrofits [39]. Figure 2-2shows the greatest barriers to implementing energy efficiency improvements in buildings worldwide. Note that this survey included a variety of commercial, industrial, and institutional facilities.

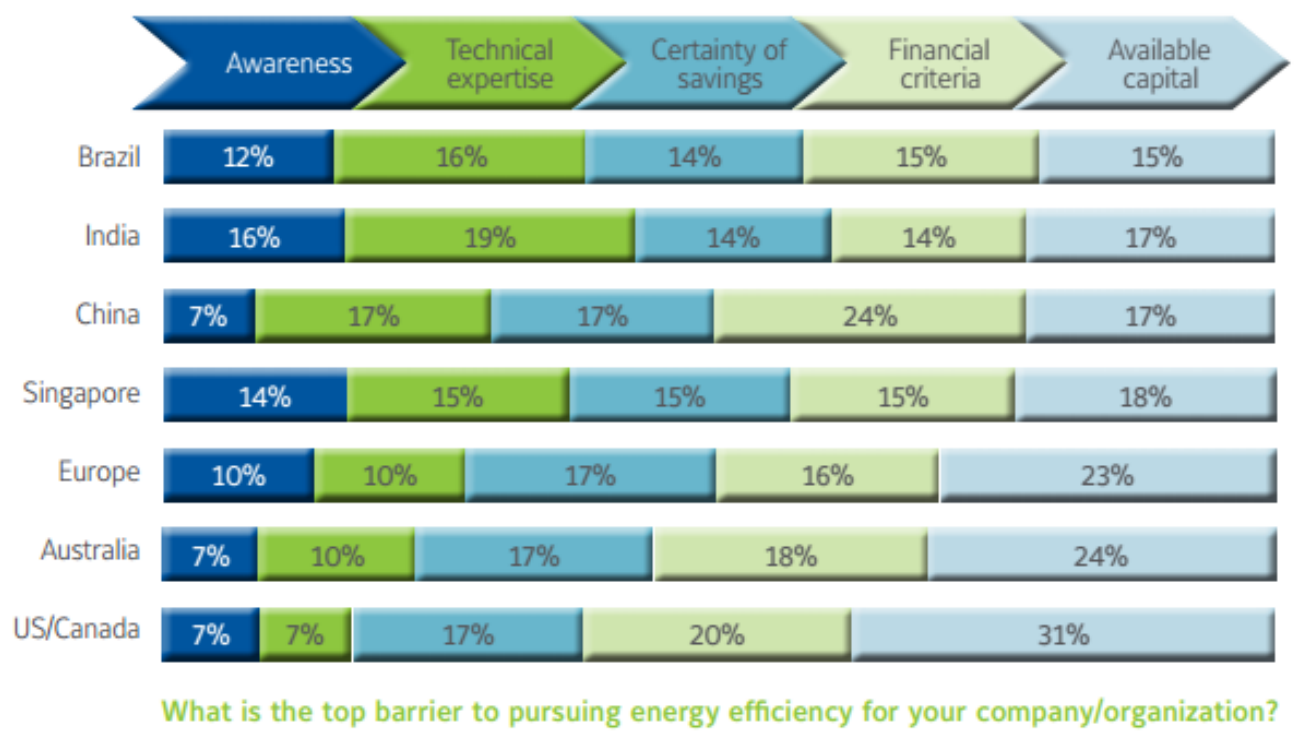

Figure 2-2 - Greatest Obstacles to Building Energy Efficiency Investment [39]

Figure 2-3, also produced from Energy Efficiency Indicator Survey results, explores financial barriers in further depth. 
Across regions organizations rely on internal funding -

budget limitations and capital competition significant.

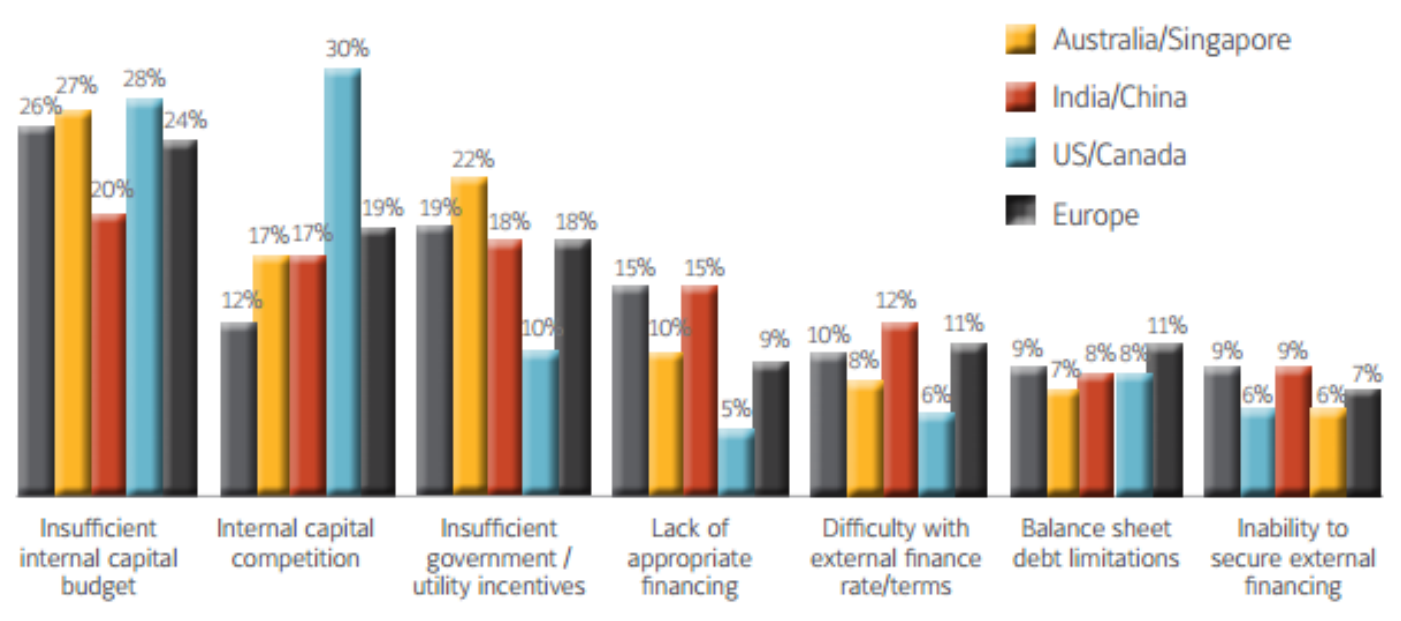

What is the top financial barrier to pursuing energy efficiency for your company/organization?

Figure 2-3 - Financial Obstacles to Improving Building Energy Efficiency [39]

In the U.S. and Canada, internal competition for capital was perceived to be the primary financial barrier. This reveals that business cases for energy efficiency improvements are perhaps not communicating a holistic whole value proposition, mainly due to a lack of evidence based on reliable market data. Current financial models used in building upgrade decision-making rely on simple payback period and net present value calculations. Most organizations focus on short-term results [31]. This type of analysis does not encompass long-term impacts of efficiency upgrades and industry mindset must change to promote longer-term sustainable investment.

Insufficient budget was also a prevalent barrier to investment in energy efficiency. There are, however, funding options available to gain access to capital for energy efficiency projects. For example, government-funded incentive programs like Ontario's saveONenergy program offer results-based reimbursements for energy retrofits that reduce consumption. Another option is financing through an Energy Service Company (ESCO), which will provide a performance guarantee and share in cost savings realized through energy consumption reductions after the project has been completed [40].

Cost is also an obstacle to innovation leadership in energy efficiency, particularly when it comes to the cost of implementing new sustainable technologies that are not yet widely-available or in demand. The organizations that choose to implement new technologies often must do so at the technology's highest cost and run the risk of failing to receive the predicted benefits of the technology. From a financial

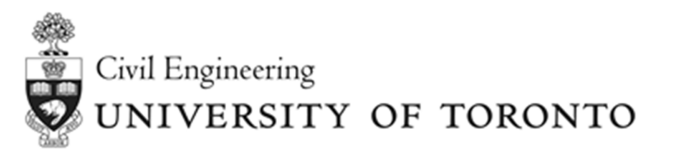

Value Impacts of Energy Efficiency Retrofits on Commercial Office Buildings in Toronto, Canada | 16 
standpoint it is perhaps better to allow other organizations to try (and pay for) a new technology and to observe the benefits before following suit at a potentially lower cost [12]. This provides disincentive for innovation and slows market transformation.

\subsubsection{Barrier 2 - Risk}

There is a certain level of risk involved in energy retrofits of commercial buildings because potential energy and consequent cost saving predictions are made before the retrofit is carried out to support the business case for the retrofit. Decision-makers must accept some uncertainty when it comes to building performance results [41]. Investors who are willing to bear longer time periods for capital recuperation for overall gain through energy savings are better positioned to accept this risk.

Another factor adding uncertainty to savings projections is the volatility of energy prices. Retrofitting decisions are very sensitive to changes in consumer energy prices although sensitivity analysis is not always conducted for different retrofit scenarios.

\subsubsection{Barrier 3 - Split Incentive}

Split incentive refers to a transaction where the benefits are not realized by the party who pays for the transaction [42]. For building energy retrofits, split incentive is a result differing motivations for energy efficiency of building owners and tenants under lease terms having only one of the parties paying for energy. Under net leases (typical for commercial buildings), energy costs are paid by tenants and building owners lack incentive to invest in efficient building systems. In gross leases (more applicable to multi-unit residential buildings), energy prices are hidden from tenants who consequently are not motivated to conserve [43]. Under these lease structures, the benefits of energy efficiency investments are not properly divided amongst the investors $[6,44]$.

A resolution to split-incentive is an energy-aligned net lease in which costs for energy efficiency improvements are passed from the owner to the tenant. This would remove energy efficiency improvement cost barriers for the owner, but would not translate into direct operating cost savings [41]. Instead, the tenants would incur costs and reap the benefits. Under an energy-aligned lease, owners pass costs of energy retrofits on to tenants based on projections for recovery of those costs; however, tenants may be averse to signing a lease that would have them pay for retrofits with uncertain results. Figure 2-4 shows how an energy-aligned lease can be modified to overcome tenant concerns.

Civil Engineering UNIVERSITY OF TORONTO
Value Impacts of Energy Efficiency Retrofits on Commercial Office Buildings in Toronto, Canada | 17 


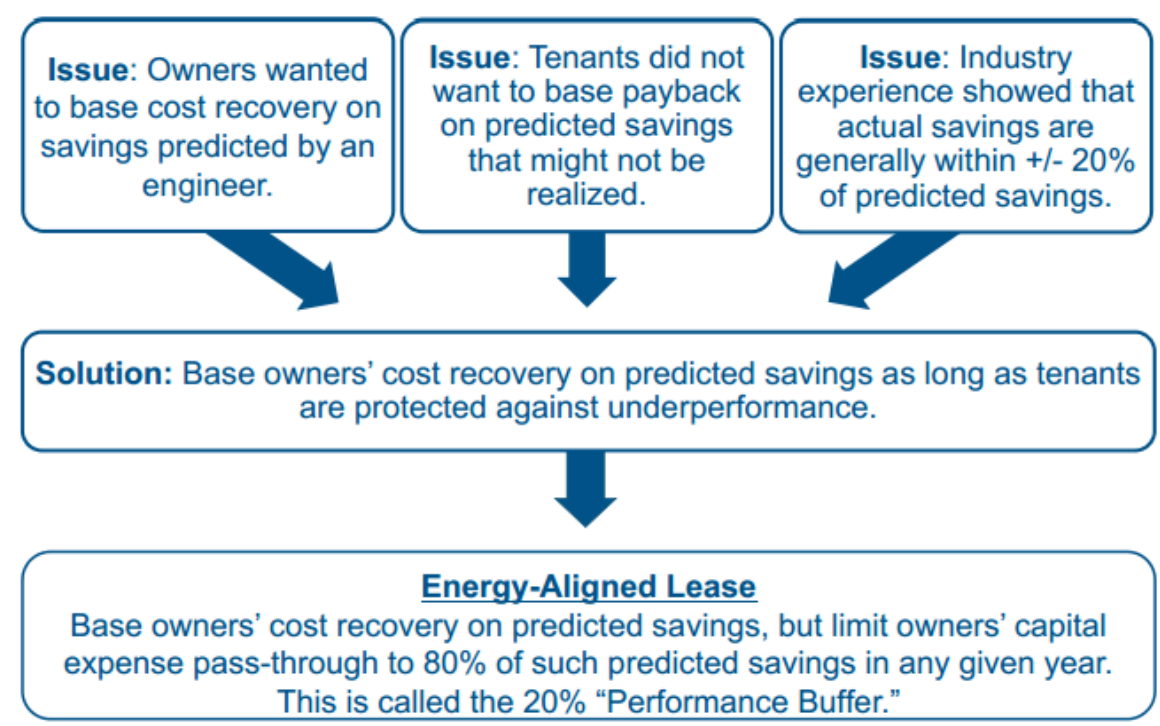

Figure 2-4 - Example of an Energy-Aligned Lease [42]

This offers one solution to the split incentive problem and thereby encourages commercial building owners and tenants to work together towards energy conservation.

\subsubsection{Barrier 4 - Lack of Data}

There is a lack of quantitative Canadian data on the financial implications of energy retrofitting existing commercial office buildings for energy improvements, making it difficult to put together a compelling business case for building owners and investors. No comprehensive public Canadian database exists for commercial building energy and financial data. There is a high level of confidentiality around financial data, particularly results of building valuations, since knowing the appraised value of a building for sale takes away some of the seller's negotiation power. The lack of data combined with secrecy surrounding the data that does exist has been the main barrier hindering research progress in this field and consequently the market does not have reliable information upon which to make energy efficiency decisions [44].

Unavailability of financial data also affects building valuation. Appraisers are unsure about how sustainability features have affected building value and whether they should support higher valuations for green buildings [6]. The valuation barrier for sustainable buildings is discussed further under Section

\subsection{5.}


Without a policy mandate, it is difficult to imagine that building owners will share their financial data with the market. Canada's National Round Table on the Environment and the Economy (NRTEE) suggested in 2009 that, without public mandatory energy use reporting policy, Canadian building data is held privately and is unavailable for the study of the motivations for investing in sustainability improvements in the commercial building sector [12]. Energy disclosure policy is discussed further under Section 2.2.6.

\subsubsection{Barrier 5 - Lack of Mechanism for Sustainable Feature Valuation}

In Canada, there is no framework for incorporating sustainable features into building appraisals (as of 2014). Without market data, it is difficult to address the differences between the definitions of "value" within the financial community and the green building industry [44]. The relationship between sustainable building features and financial benefit must be understood and proven in order for these industries to arrive at a definition of "value" that suits them both. Until such a definition is derived, it will be very difficult for appraisers to determine how to incorporate energy efficiency features into asset value calculations. This in turn affects market potential of green buildings because they are not being recognized for their added value over conventional types. The question then becomes: how is this cycle broken in order for sustainable features to impact building value? Do appraisers lead and thereby provide incentive to go green, or do they follow market data when and if it becomes available?

\subsubsection{Barrier 6 - Lack of Energy Policy Implementation}

There is no policy within Canada requiring mandatory energy reporting for buildings or disclosure of building energy to the public. Energy reporting and disclosure law for commercial buildings would provide conservation incentive to owners and operators seeking to avoid negative reputational impacts of poorly performing buildings and accelerate market transformation [41, 45]. Mandatory energy reporting and disclosure policy would also promote the provision of data that would be useful to researchers, appraisers, builders, buyers, and the market at large.

Although owners do not need to publicly disclose building energy consumption, energy efficiency considerations have begun to take root in other forms. Ontario's Building Code Act (OBC) 1992 was amended in 2011 to incorporate Supplementary Standard SB-10 "Energy Efficiency Supplement" for large buildings. SB-10 requires new buildings to be constructed to conform to the ASHRAE 90.1 Energy Standard for Buildings and to outperform the Model National Energy Code for Buildings (MNECB) 1997

Civil Engineering UNIVERSITY OF TORONTO
Value Impacts of Energy Efficiency Retrofits on

Commercial Office Buildings in Toronto, Canada | 19 
by $25 \%$ [46]. SB-10 pertains to new construction only; nevertheless, its incorporation into the OBC is a positive step toward an industry-wide sustainable policy.

Market transformation toward sustainable buildings is occurring elsewhere for existing buildings. For example, in New York, San Francisco, Seattle, and Washington D.C., energy disclosure laws for specific building types are providing new insight into building energy and fueling a competitive sustainable building market [32]. The U.S. Department of Energy and the Appraisal foundation have partnered to educate appraisers to account for sustainable building features based on the data collected mainly in cities with energy disclosure mandates [32]. It stands to reason that Canada could follow a similar path to achieve its own market transformation.

Several problems could arise, however, if mandatory energy disclosure policy was implemented. The first is potential weakness of enforcement mechanisms, without which the policy would be rendered ineffective [41]. Another issue is that, although the identification of underperforming buildings would help in the determination of retrofit potential, it would also render underperformers less valuable because of the negative effect on owner and tenant corporate reputation. Many owners of old buildings would therefore be opposed to the implementation of energy disclosure policy [27, 45]. However, mandatory energy disclosure policy would reward responsible building owners and so these owners might be inclined to support such a movement.

In 2009, the Canadian National Round Table on the Environment and the Economy (NTREE) made numerous policy recommendations for Canada to meet the GHG emission reduction goals for buildings that were agreed to in the Copenhagen Accord, including [12]:

- Mandatory energy consumption labels for products and buildings, particularly public buildings;

- Market-wide price signals with a clear and consistent price on carbon so that consumers respond appropriately to energy price fluctuations;

- Energy code/building code requirements;

○ Minimum energy performance standards for equipment in buildings;

○ Subsidies for energy efficiency improvements/technologies;

- Subsidies for energy efficiency research and development; and

- Public education and skills training to affect behaviour and promote awareness.

Civil Engineering UNIVERSITY OF TORONTO
Value Impacts of Energy Efficiency Retrofits on Commercial Office Buildings in Toronto, Canada | 20 
Without government policy pushing the Canadian building market to conserve energy, it is unlikely that Canada will meet its 2020 GHG emission goals.

\subsubsection{Barrier 7 - Low Cost of Energy}

Low consumer energy prices are a barrier not only to energy retrofits but to energy conservation in general. Price signals guide consumers' treatment of resources, i.e. higher price should indicate scarcity and encourage conservation of the resource. Current market prices indicate to consumers that energy is readily available in Canada and therefore there lacks significant financial incentive to reduce energy consumption. Several studies have used survey approaches to determine if and how building owners perceive impacts of low energy costs on energy conservation.

By surveying building owners and operators, several studies have determined that the low cost of energy in Canada inhibits green building investment [25,47]. Specific to commercial building energy retrofits, building owners and operators perceive energy consumption reduction to be a secondary consideration when deciding whether to undertake retrofit projects because of the low cost of energy [47].

There are several price signals affecting Canadian energy consumer behaviour. Government subsidizing of energy prices shields the real cost of energy production from consumers and results in less investment in energy efficiency and conservation [12]. According to a study conducted by the International Monetary Fund, Canada spent approximately \$26 billion to subsidize energy in 2011, equal to $4 \%$ of government revenues or approximately $\$ 787$ per capita $[48,49]$. Removing energy subsidies globally could lead to a $13 \%$ reduction in $\mathrm{CO}_{2}$ worldwide and slow the depletion of natural resources [49].

Average cost billing limits behavioural change since end-users pay no mind to when they consume energy even though it costs more to produce during peak periods [12]. Some Canadian electrical utility companies have begun charging higher rates for electricity used during peak hours to reduce the burden on the grid. This signals to consumers that there is less availability of electricity during these times and the behavioural response is to use less electricity or to use electricity at off-peak times.

Canadian energy prices do not include environmental and human health cost impacts resulting from energy production and use, making prices artificially low [12]. The price of Canadian energy captures

Civil Engineering UNIVERSITY OF TORONTO
Value Impacts of Energy Efficiency Retrofits on Commercial Office Buildings in Toronto, Canada | 21 
only a narrow portion of the life cycle of the fuels used to produce it. This is particularly an issue for natural gas, which is not only subsidized and average-cost billed in Canada but whose use also emits massive amounts of GHGs annually. For example, Enbridge Gas Distribution provides natural gas to Toronto at an effective rate (commodity price plus cost adjustment) of $18.5 \mathrm{c} / \mathrm{m}^{3}$ (July 2014) [50]. Toronto Hydro provides electricity to Toronto at a rate of up to $10.1 \mathrm{c} / \mathrm{kWh}$ for commercial buildings with monthly demand over $50 \mathrm{~kW}$ (May 2014) [51]. One cubic metre of natural gas produces approximately the equivalent of $10.33 \mathrm{kWh}$ of electricity [52]; therefore, if natural gas was priced at the same rate per unit energy as electricity, natural gas would cost $\$ 1.04 / \mathrm{m}^{3}$ (over 5 times as much). If GHG emissions were taken into account, relative to electricity, the price of natural gas would be even higher. In Toronto Ontario, $\mathrm{CO}_{2}$ equivalent GHG emissions are $1.891 \mathrm{kgCO} / \mathrm{m}^{3}$ of natural gas compared to 0.11 $\mathrm{kgCO}_{2} / \mathrm{kWh}$ of electricity [53]. Therefore, based on environmental impact, natural gas should cost 1.6 times as much as electricity as it emits 1.6 times the amount of $\mathrm{CO}_{2}$ equivalent $\mathrm{GHG}$ emissions per unit energy output. This would raise the previously-calculated electricity-equivalent price to $\$ 1.74 / \mathrm{m}^{3}$, over 9 times as much as the current consumer price.

Energy pricing model reform to accurately reflect the life cycle costs of energy consumption would give consumers a clearer picture of Canada's energy market, facilitate behavioural changes, and drive energy efficiency and conservation investment in buildings.

\subsection{Measuring Building Energy Retrofit Impacts}

The following sections describe indicators that can be used to measure energy retrofit impacts in terms of the sustainability "triple bottom line".

\subsubsection{Environmental Indicators}

Environmental indicators of building energy retrofit impacts have been well-developed and documented. As a result, there is no skepticism in the marketplace as to the benefits of building energy retrofits from an environmental perspective. Environmental indicators commonly used to measure retrofit impacts are energy consumption pre- and post-retrofit (from any and all sources, including natural gas, electricity, and steam), energy demand, and greenhouse gas emissions. These can be presented in terms of actual energy use or as percentage reductions/increases for added context. Actual energy use terms can be used for comparison amongst similar buildings (benchmarking); energy use index (EUI) was developed for this purpose. EUI is the annual energy usage of a building divided by

Civil Engineering UNIVERSITY OF TORONTO
Value Impacts of Energy Efficiency Retrofits on Commercial Office Buildings in Toronto, Canada | 22 
the building's gross floor area. This allows for the comparison of buildings with similar uses in similar climates of different sizes to be compared based on energy performance. Green building rating systems such as LEED, BOMA BESt, and ENERGY STAR are also used as environmental indicators for buildings; refer back to Section 1.4 for descriptions of the rating systems.

\subsubsection{Social Indicators}

Measuring the social implications of energy efficiency improvements in buildings through retrofitting is an essential endeavour as human health is extremely valuable. However, this research does not seek to quantify value in this way. Social factors are discussed in this report as a result of environmental effects and are not measured explicitly. The purpose of their mention here is to inform the reader that, although outside of this scope, the measurement of retrofit impacts on sustainability is incomplete without the social aspect.

\subsubsection{Financial Indicators}

\subsubsection{Simple Payback Period}

In contrast to the proven and accepted environmental indicators, financial indicators of building energy retrofit success are under continual development and scrutiny. In the past, simple playback period has been the most widely-used measurement for the economic implications of energy retrofits [54]. Simple payback period is the capital cost of the building improvement divided by the energy cost savings resulting from the improvement. For example, a retrofit costing $\$ 10,000$ that results in annual energy cost savings of $\$ 2,000$ has a simple payback period of 5 years. This calculation has been used to evaluate complete building energy retrofits, individual retrofit measures, and combinations of measures. However, this indicator has been criticized as short-sighted as it does not account for the effects of the retrofit investment past its capital cost's pay-off [31]. Additionally, simple payback period as an indicator does not consider changing utility prices and instead considers energy prices as fixed [30].

\subsubsection{Life Cycle Cost Analysis}

Recent developments have seen the addition of life cycle cost analysis (LCCA) as a financial evaluation tool for retrofits [54]. This method aims to determine whether a retrofit investment will generate a positive return on investment (ROI) over the life of the retrofit technology [55]. LCCA employs internal rate of return (IRR) and net present values (NPV) as specific measures to help decision-makers invest

Civil Engineering UNIVERSITY OF TORONTO
Value Impacts of Energy Efficiency Retrofits on Commercial Office Buildings in Toronto, Canada | 23 
capital wisely and to measure investment success/failure [54]. LCCA considers interest, inflation, and utility price increases [56]. The LCCA method can also include "cost of conserved energy" (CCE): the extra cost on an annual basis (considering interest) divided by resultant annual energy savings [57]. A higher CCE would indicate higher investment cost and diminishing energy cost savings. LCCA is a much more comprehensive evaluation method than simple payback period calculation and contains a great deal more information, thereby making it not only more accurate but also more useful to building owners and investors.

However, LCCA neglects an important factor which might not be immediately tangible in a financial sense, but which actually comprises the largest expense of any commercial building: the tenants. This gap was identified in 2003 by Gregory Kats, who sought to demonstrate that sustainable building is a sound financial investment [58]. The study examined the costs of 33 California green buildings compared to conventional designs for those buildings (new construction only), and used life cycle costing with NPV to determine the financial benefits form lower energy costs, waste costs, water costs, operational and maintenance costs, and increased tenant productivity and health. Note that for the purposes of the Kats study, costs and benefits are only considered over the life of the building and upstream/downstream costs such as manufacturing of construction materials were not included.

Kats concluded that, for the 33 buildings studied, average annual employee costs were ten times larger than the property cost per employee (including energy, operation and maintenance (O\&M) costs, and rent) [58]. From this sample it was concluded that a unitary increase in employee costs results in a tenfold increase in property related costs. Therefore an increase in productivity by $1 \%$ through sustainability implements should have the same financial impact as reducing property costs by $10 \%$ [58]. The study also concluded that, for the observed buildings, green construction had a price premium of around $2 \%$ over their conventional counterparts, which was much lower than industry perception at the time.

In addition to highlighting the importance of productivity and health effects of green building compared to conventional building practices, this study identified several important research gaps.

1. Tracking green buildings in the marketplace could confirm or deny the hypothesis that more comfortable and healthier buildings with consequent increased tenant productivity should be in

Civil Engineering UNIVERSITY OF TORONTO
Value Impacts of Energy Efficiency Retrofits on Commercial Office Buildings in Toronto, Canada | 24 
greater demand than conventional buildings and therefore should be able to achieve higher rents and lower vacancy rates.

2. More case studies including LCCA (particularly using internal rate of return) could provide building owners with proof of the benefits of sustainable building.

3. Studies on tenant lease-up of green buildings could show that green building marketability attracts tenants faster resulting in substantial financial savings to the owner; and, of most interest to this study.

4. The connection between sustainable building benefits and building value, which had not been determined at the time of the Kats study, is not widely being used in North American building appraisals today.

\subsubsection{Building Asset Value}

The most recent development in building energy retrofit economics is the idea that an energy retrofit will affect building asset value. Extensive surveys have been undertaken in North America and abroad to gather qualitative data on the relationship between building sustainability and building asset value. These studies generally show that owners and tenants are willing to pay a premium for sustainable buildings, particularly those with eco-labels as discussed in Section 1.4 [41]. In general, participants in the studies recognized the growing demand for sustainable buildings and had the expectation that this growth would continue $[23,24]$.

This research suggests that green buildings can improve asset value as they can [44]:

- Secure tenants more easily and experience lower turnover rates;

- Improve tenant productivity;

- Command higher rents or prices;

- Cost less to operate and maintain; and

- Attract grants and subsidies associated with energy conservation and GHG emission reduction.

Many case studies have shown a relationship between building sustainability and lower energy costs among other benefits as discussed in Section 2.1. However, there is a lack of quantitative evidence on the relationship between these benefits and building value. A 2012 Appraisal Institute global study presented the problem as such: "there are many case studies that document how energy efficiency and green building design have led to lower energy costs, improved financial performance, and other

Civil Engineering UNIVERSITY OF TORONTO
Value Impacts of Energy Efficiency Retrofits on Commercial Office Buildings in Toronto, Canada | 25 
benefits for owners. Much less common are studies that show actual quantitative effects of documented energy performance on the appraised value or market-defined sale price of the building" [27]. This study suggests that the lack of definitive, quantitative studies is not a result of a lack of relevant cases to study but rather an issue of access to data.

\subsection{Review of Related Empirical Studies}

Quantitative North American research on the relationship between building sustainability and building asset value began in the mid- to late-2000s and uses existing green rating systems, particularly LEED EB:OM and ENERGY STAR scores, as sustainability indicators. These rating systems include energy efficiency as an important sustainability factor.

The vast majority of the North American empirical research on the relationship between building sustainability and value has been done in the United States and yet there is very little insight into the Canadian market. This difference in data availability is largely due to the U.S. CoStar database - a comprehensive database of real estate information for over 2.8 million U.S. commercial properties [59]. Canada has no comparable building information database. Research using the CoStar database has led to quantitative conclusions about relationships between building sustainability and building value.

This study, although Canadian, will compare Canadian (Toronto) results to American studies. This comparison is valid for the following reasons [35]:

- Canada and the U.S. employ similar building design and construction practices;

- Canadian and U.S. construction and engineering industries are intertwined, with many companies in this sector doing business in both countries;

- many Canadian and U.S. building design and operation standards are similar;

- Canadian construction costs are similar to U.S. construction costs;

- Canadian and U.S. corporate workplace culture is quite similar; and

- Canadian and U.S. citizens in general are aware of and concerned about environmental conservation and corporate social responsibility.

There are some differences, however, in political and climatic landscapes between Canada and certain parts of the U.S., particularly in southern states [35]. For example, buildings in southern states would have very different heating and cooling loads than Canadian buildings. Unfortunately, most of the

Civil Engineering UNIVERSITY OF TORONTO
Value Impacts of Energy Efficiency Retrofits on Commercial Office Buildings in Toronto, Canada | 26 
studies undertaken in this area of research do not differentiate between U.S. climatic regions. However, it is believed that these studies offer the best basis for comparison to similar Canadian studies including this thesis.

Table 2-1 was created by the author to summarize the related empirical studies on the relationship between sustainability as defined by green certification and building value as observed through rental and sale price premia. Studies have been numbered for clarity. Note that there is one study on buildings outside of North America (Study 8). 
Table 2-1- Summary of Empirical Studies

\begin{tabular}{|c|c|c|c|c|c|c|c|c|c|c|}
\hline Study & Authors & $\begin{array}{l}\text { Publishing } \\
\text { Year }\end{array}$ & $\begin{array}{c}\text { Study } \\
\text { Location }\end{array}$ & Database & $\begin{array}{l}\text { Approximate } \\
\text { Sample Size }\end{array}$ & $\begin{array}{l}\text { Building } \\
\text { Certification }\end{array}$ & Rental Results & $\begin{array}{c}\text { Sales } \\
\text { Results }\end{array}$ & $\begin{array}{l}\text { Occupancy } \\
\text { Results }\end{array}$ & Other Conclusions \\
\hline \multirow{3}{*}{1} & \multirow{3}{*}{$\begin{array}{l}\text { Eichholtz, Kok, } \\
\text { Quigley [28] }\end{array}$} & \multirow{3}{*}{2010} & \multirow{3}{*}{ U.S. } & \multirow{3}{*}{ CoStar } & \multirow{3}{*}{10,000} & Green* & $+3.5 \%$ & & & \\
\hline & & & & & & LEED & $+5.2 \%$ & & & \\
\hline & & & & & & ENERGY STAR & $\begin{array}{c}\quad+3.3 \% \\
+7 \% \text { effective }\end{array}$ & $+16 \%$ & & \\
\hline \multirow{2}{*}{2} & \multirow{2}{*}{$\begin{array}{l}\text { Eichholtz, Kok, } \\
\text { Quigley [60] }\end{array}$} & \multirow{2}{*}{2013} & \multirow{2}{*}{ U.S. } & \multirow{2}{*}{ CoStar } & \multirow{2}{*}{27,000} & Green & $\begin{array}{l}+2.8 \% \text { to } 3.5 \% \\
+8 \% \text { effective }\end{array}$ & $+13 \%$ & & \\
\hline & & & & & & LEED & \multicolumn{4}{|c|}{$\begin{array}{l}\text { Premia for LEED buildings are significantly higher than the premia for ENERGY } \\
\text { STAR buildings (rent and sale). }\end{array}$} \\
\hline \multirow[b]{2}{*}{3} & \multirow{2}{*}{$\begin{array}{l}\text { Fuerst, } \\
\text { McAllister [29] }\end{array}$} & \multirow[b]{2}{*}{2011} & \multirow[b]{2}{*}{ U.S. } & \multirow[b]{2}{*}{ CoStar } & \multirow[b]{2}{*}{16,500} & LEED & $+5 \%$ & $+25 \%$ & & \multirow{2}{*}{$\begin{array}{l}\text { Higher certification levels } \\
\text { (ENERGY STAR or LEED) } \\
\text { achieve higher price } \\
\text { premia. }\end{array}$} \\
\hline & & & & & & ENERGY STAR & $+4 \%$ & $+26 \%$ & & \\
\hline \multirow{2}{*}{4} & \multirow{2}{*}{$\begin{array}{l}\text { Miller, Spivey, } \\
\text { Florance [61] }\end{array}$} & \multirow{2}{*}{2008} & \multirow{2}{*}{ U.S. } & \multirow{2}{*}{ CoStar } & \multirow{2}{*}{2,500} & LEED & $+50 \%$ & $+9.9 \%$ & $+4.2 \%$ & \multirow{2}{*}{$\begin{array}{l}\text { Note: based on previous } \\
\text { works by authors of } 1,2,3 \text {. }\end{array}$} \\
\hline & & & & & & ENERGY STAR & $+8.9 \%$ & $+5.3 \%$ & $+3.7 \%$ & \\
\hline 5 & $\begin{array}{l}\text { Pivo, Fisher } \\
\text { [62] }\end{array}$ & 2010 & U.S. & NCREIF & 1,199 & ENERGY STAR & $+5.2 \%$ & $+8.5 \%$ & $+1.3 \%$ & $\begin{array}{l}\mathrm{NOI}+2.7 \% \text {. } \\
\text { No significant difference in } \\
\text { total operating expenses. } \\
\text { Utility expenses - } 12.9 \% \text {. }\end{array}$ \\
\hline \multirow{2}{*}{6} & \multirow{2}{*}{$\begin{array}{l}\text { Wiley, } \\
\text { Benefield, } \\
\text { Johnson [63] }\end{array}$} & \multirow{2}{*}{2010} & \multirow{2}{*}{ U.S. } & \multirow{2}{*}{ CoStar } & \multirow{2}{*}{7,400} & LEED & $\begin{array}{c}+15.2 \% \text { to } \\
17.3 \%\end{array}$ & & $+16 \%$ to $18 \%$ & \\
\hline & & & & & & ENERGY STAR & $+7.3 \%$ to $8.6 \%$ & & $+10 \%$ to $11 \%$ & $\begin{array}{l}\text { ENERGY STAR building - } \\
40 \% \text { energy use. }\end{array}$ \\
\hline 7 & $\begin{array}{l}\text { Kok, Miller, } \\
\text { Morris [26] }\end{array}$ & 2012 & U.S. & CoStar & 974 & LEED & $+7.1 \%$ & & $+2 \%$ & $\begin{array}{l}\text { Additional premium for } \\
\text { ENERGY STAR on top of } \\
\text { LEED. }\end{array}$ \\
\hline 8 & $\begin{array}{l}\text { Chegut, } \\
\text { Eichholtz, Kok, } \\
{[64]}\end{array}$ & 2013 & UK & $\begin{array}{l}\text { CoStar } \\
\text { (London) }\end{array}$ & 10,000 & Green & $\begin{array}{c}+2 \% \\
+6 \% \text { effective }\end{array}$ & $+16 \%$ & & $\begin{array}{l}\text { "Green gentrification" } \\
\text { concept. }\end{array}$ \\
\hline 9 & Clift [65] & 2014 & Canada & Altus & 32 & LEED & No conclusive res & & & \\
\hline
\end{tabular}


Study 1 was completed in 2010 and quantitatively linked sustainability and energy performance improvements to increased building asset value. This was a large-scale study that presented the analysis and interpretation of data from the CoStar database. This study's sample included 1,360 green buildings, 694 with monthly rent information and 199 with sale information [28]. This study set the landscape for subsequent studies linking building asset value increases to energy performance improvements by measuring rent and selling price variations, which reflect willingness to pay for green buildings.

Of the buildings included in this study, 286 were LEED EB:OM certified, 1,045 were ENERGY STAR certified, and 29 had both certifications [28]. The complete sample of buildings analyzed was 8,105 buildings with rental data and 1,813 buildings with sale data [28]. Study 1 yielded the following results [28]:

1. a green-rated building commands a rent premium of approximately $3.5 \%$ over an un-rated building;

2. a LEED certified building commands a rent premium of approximately $5.2 \%$ over an un-rated building;

3. an ENERGY STAR certified building commands a rent premium of approximately $3.3 \%$ over an un-rated building;

4. an ENERGY STAR certified building commands an effective rent (rent multiplied by occupancy rate) premium of approximately $7 \%$ over an un-rated building; and

5. an ENERGY STAR certified building can sell for up to $16 \%$ more than a comparable un-rated building.

Note that the effective rent premium is higher than the rent premium for ENERGY STAR buildings; this is likely due to occupancy data not being available for all buildings.

The study also discusses the impact of the green label itself, concluding that amongst green-rated buildings, there is an inverse relationship between energy usage and market value; this implies that the increase asset value of a green building does not hinge solely on the green label and the perception of sustainability. However, it is noted that the perception of sustainability independent of actual sustainability improvements does impact the value of green buildings in the marketplace because of corporate social responsibility commitments and tenant beliefs about improved productivity [28]. 
Therefore, the definition of a building as sustainable by its green label might not only increase marketability by being more a more efficient and healthier building but may also increase marketability as a socially responsible investment.

In 2013, the same research group expanded their research. In Study 2, a study of 21,000 rental commercial buildings and 6,000 commercial building sales across the U.S. were examined [60]. They generally found the same results, estimating that a green-rated building has a rental premium of $2.8 \%$ to $3.5 \%$, an effective rent premium of almost $8 \%$, and a selling price premium of approximately $13 \%$ over a non-rated building [60]. It was also noted that the premia for LEED buildings is significantly higher than the premia for ENERGY STAR buildings [60]. This is possibly a result of rating system marketing and comprehensiveness. Similar to their previous work, this study also found that, by comparison amongst green certified buildings, rent and asset value variations were "systematically related" to sustainability indicators as measured by the green rating systems [60].

Study 3 was published in 2011 and also drew on the CoStar database for information. This study sampled 1393 ENERGY STAR buildings and 324 LEED buildings in the U.S. along with over 15,000 benchmark buildings, yielding the following results [29]:

1. an ENERGY STAR building commands a rental premium of $4 \%$ over a non-certified building;

2. a LEED building commands a rental premium of $5 \%$ over a non-certified building;

3. an ENERGY STAR building commands a sale price premium of $26 \%$ over a non-certified building;

4. a LEED building commands a sale price premium of $25 \%$ over a non-certified building; and

5. higher certification levels (ENERGY STAR or LEED) achieve higher price premia.

The rent results are similar to those found in Study 1. The selling price results, however, are significantly higher.

Study 4 was one of the first published in this area of research (2008). This study focused on the direct real estate benefits of green certification and found the following results from a sample approximately 2,500 buildings in the CoStar database (results per $\mathrm{ft}^{2}$ ) [61]: 
Table 2-2 - Study 4 Results [61]

\begin{tabular}{ll}
\hline $\begin{array}{l}\text { Rent } \\
\text { Green Buildings }\end{array}$ & \\
$\begin{array}{l}\text { Energy Star } \\
\text { LEED }\end{array}$ & $\$ 30.50 / \mathrm{ft}^{2}$ \\
Control Sample & $\$ 42.15 / \mathrm{ft}^{2}$ \\
Occupancy Rate & $\$ 28.00 / \mathrm{ft}^{2}$ \\
$\begin{array}{l}\text { Green Buildings } \\
\text { Energy Star }\end{array}$ & \\
$\begin{array}{l}\text { LEED } \\
\text { Control Sample }\end{array}$ & $91.5 \%$ \\
$\begin{array}{l}\text { Regression model controlled Log } \\
\text { of Effective Rent Per Sq Ft } \\
\text { LEED Rent Differential \% }\end{array}$ & $92.0 \%$ \\
$\begin{array}{l}\text { Energy Star Rent Differential \% } \\
\text { Value Per Sq Ft (regression result) } \\
\text { LEED }\end{array}$ & $87.8 \%$ \\
Energy Star & \\
\hline
\end{tabular}

A much larger rental premium for green (LEED and ENERGY STAR) buildings was observed in Study 4 than in other studies; for example, the results above reveal a rental rate increase of $50 \%$ for LEED buildings over conventional buildings. The authors indicate that LEED and ENERGY STAR buildings tend to be newer or retrofitted recently and these factors might account for such large differences. With controls for building age, location, and time of sale, the gap would decrease. Overall the study was in agreement that green buildings command higher rents and sale prices and have higher occupancy rates than conventional buildings.

Study 5 (2010) was the only American study analyzing the National Council of Real Estate Fiduciaries (NCREIF) quarterly data for office properties between 1999 and 2008 [62]. ENERGY STAR labeling was used to define a property as energy efficient and geographical data were used to determine whether a property was close to transit. These sustainability indicators were also used in this study a to define responsible property investment (RPI): "investment and development decisions that are responsive to the social, environmental, and economic concerns of all affected stakeholders" [62]. The results of Study 5 are [62]:

1. ENERGY STAR buildings had net operating incomes $2.7 \%$ higher than non-certified buildings from a combination of higher rents, higher occupancy, and/or lower expenses;

2. there was no significant difference in total operating expenses for ENERGY STAR properties compared to non-certified buildings but utility expenses per unit area were $12.9 \%$ lower;

3. ENERGY STAR buildings command a rental premium of $5.2 \%$ over non-certified buildings; 
4. ENERGY STAR buildings are occupied at a rate of $1.3 \%$ higher than non-certified buildings;

5. ENERGY STAR buildings are worth $8.5 \%$ more per unit area than non-certified buildings according to NCREIF appraised values and sale transaction data.

Study 6 was published in 2010 and analyzed the CoStar Property and COMPS databases for the year 2008. Over 7,300 Class A commercial office properties with rental and occupancy data were included in this study. Study F yielded [63]:

1. a LEED building commands a rent premium of $15.2 \%-17.3 \%$ over comparable nongreen rated buildings;

2. an ENERGY STAR property commands a rent premium of $7.3 \%-8.6 \%$ over non-green rated buildings;

3. LEED buildings had occupancy levels $16 \%$ - 18\% higher than non-green buildings;

4. ENERGY STAR buildings had occupancy levels $10 \%-11 \%$ higher than non-green buildings;

5. Commercial buildings with the ENERGY STAR label use nearly $40 \%$ less energy than average buildings.

Study 7 was published in 2012 and is based on the results from Study 1, Study 3, and Study 4. Similarll to previous works, this study was based on the CoStar database. It included 374 LEED and 600 control properties. For LEED buildings versus non-LEED buildings, a $7.1 \%$ rental premium was observed [26]. It was determined that there was also an additional premium for ENERGY STAR on top of LEED. These results are similar to but slightly higher than those from previous studies. It was also observed that the occupancy rate of green buildings is approximately $2 \%$ higher than in comparable conventional buildings, which lends to higher effective rents [26].

Study 8, published in 2013, builds on all previously mentioned research on the subject of commercial building performance and asset value, this time focusing on London, UK and "green gentrification". Results drawn from previous research were [64]:

1. an ENERGY STAR or LEED building commands a rental premium of $2 \%$ over a non-certified building;

2. an ENERGY STAR or LEED building commands an effective rental premium of approximately $6 \%$ over a non-certified building; and

Civil Engineering UNIVERSITY OF TORONTO
Value Impacts of Energy Efficiency Retrofits on Commercial Office Buildings in Toronto, Canada | 32 
3. an ENERGY STAR certified building can sell for up to $16 \%$ more than a comparable un-rated building.

These results were taken from Study 1 . Study 8 also documents the growth and concentration in commercial green buildings in London and it was observed that the increase of commercial green building supply in a neighbourhood decreases premia for green buildings over non-green buildings but has an overall positive impact on average rents and sale prices of commercial buildings in the same neighbourhood. This effect was referred to as "green gentrification" [64]. This means that, as green buildings become the norm, their rental and sale price premia will actually decrease.

Study 9 is (to the author's knowledge) the only previous Canadian study with quantitative data on the relationship between building sustainability and asset value [65]. It was written in 2014 for a Memorial University course and is unpublished.

Study 9 compares LEED-rated office buildings in Toronto and the Greater Toronto Area (GTA) to nonLEED office buildings using the income approach which is based on net operating income and capitalization rate. This study analyzes financial data of 14 buildings in the downtown market and 18 buildings in the GTA market. This data includes operating costs, rental rates, absorption rates, yields (internal rate of return and capitalization rate), and marketing considerations.

The small sample size of Study 9 and lack of data made it difficult for conclusions to be drawn. There was little difference in operating costs observed in LEED and non-LEED buildings in the downtown market but lower operating costs were observed for LEED buildings in the GTA suburban market. Analysis of rental rates and absorption rates was inconclusive. No yield discount for LEED buildings was observed. Overall, this study provides little evidence that LEED certification has an effect on market value for Toronto commercial office buildings [65].

However, Study 9 did confirm the following qualitative results [65]:

- there is strong demand for LEED certified buildings in Canada;

- to remain competitive, new buildings are being constructed or renovated to LEED standards;

- tenants are becoming more conscious about their environmental footprint;

- non-LEED or non-green buildings may be at risk as time progresses.

Civil Engineering UNIVERSITY OF TORONTO
Value Impacts of Energy Efficiency Retrofits on Commercial Office Buildings in Toronto, Canada | 33 
Lack of available data due to the competitive nature of the commercial building real estate sector and confidentiality concerns was the greatest obstacle to Study 9 [65]. The author also states that comparison between buildings is made difficult by the heterogeneous nature of real estate [65]. Directly comparing buildings to one another is difficult when building ages, locations, construction types, and other features vary. Furthermore, it was noted that analyzing rental rates during two different time periods can yield misleading results [65].

The results of the conclusive quantitative North American studies generally agree that that greencertified buildings command higher rents and selling prices than non-certified buildings. Green building rental premia were found to vary between $2.8 \%$ and $50 \%$ above non-certified buildings. Study 4 had significantly higher rental rate results than the others. If this study were considered an outlier, the rest of the studies would indicate rental premia being between $2.8 \%$ and $17.3 \%$ for green buildings over noncertified buildings. Effective rental premia for green buildings were included in two North American studies with common authors. They ranged between $7 \%$ and $8 \%$ above non-certified buildings.

Selling prices were between $5.3 \%$ and $26 \%$ above non-certified buildings. Again, one study (Study 3 ) had much higher sale price premia results than the others (this was not the same study where significantly higher rental premia were observed; consult Table 2-1 for details). If the study with much higher sale premia results were considered an outlier, the rest of the studies would indicate a sales premium between 5.3\% and 16\% over non-green buildings. These "outlier" studies are no less reputable or accurate than the other studies, but have been identified here for the purpose of conservative discussion of results.

It is important to note that most of these studies are interdependent and draw from results of those before. The results of these studies, therefore, may be affected by their predecessors. Additionally, similarities in methodologies used for these studies may have contributed to similarities in results. Research into previous studies highlights several of gaps in the study of the relationship between building energy efficiency and asset value.

1. Quantified research on the relationship of building sustainability to asset value is a recent development and data is limited [6].

2. Compared to qualitative research, there has been little empirical, quantitative study of this relationship. 
3. No previously published studies have examined buildings before and after retrofits.

4. No previous published study has made conclusions on this relationship using Canadian data.

These are the gaps that this study will begin to address. 


\section{Building Valuation}

The Canadian Uniform Standards of Professional Appraisal Practice (CUSPAP) defines market value as: "the most probable price which for which a property should sell after reasonable exposure in a competitive market under all conditions requisite to a fair sale, the buyer and seller each acting prudently, knowledgeably, and for self-interest, and assuming that neither is under undue duress" [66]. Valuation is an estimate of this price [67]. For building valuation, it is useful to use transactions (achieved rents and prices) rather than comparables (asking rents and prices) because transactions effectively reflect market willingness to pay [67]. The main challenge for appraisers seeking to account for sustainability aspects in valuations of buildings has been identified as developing methods for capturing the effects of sustainability in buildings and quantifying these effects for application in valuation [68]. This means that there needs to be a clear, consistent way of appraising sustainable buildings. The introduction of sustainability into valuation practices and current valuation methods are discussed next.

\subsection{Valuation of Sustainable Building Features}

A 2011 review of literature revealed that there are three ways in which sustainable features can be accounted for in the process of building valuation [68].

1. Calculate building value without accounting for sustainable features and then adjust for sustainability. This means of incorporating sustainability into valuation is problematic because building systems, including sustainable attributes, affect one another and therefore cannot be evaluated accurately as one additional value.

2. Calculate a sustainability correction factor to apply to the conventional valuation result. This approach has the same issue as the previous approach.

3. Hedonic pricing, the most complex of the three potential methods but is the most consistent with current valuation methods and would most accurately account for the effects of sustainability features in buildings. Hedonic pricing breaks the building pricing down into its components. This technique has the most potential to correlate sustainable development effects to financial returns [22].

This study also found four main arguments in favour of the need to integrate sustainability considerations into building valuation [68]. 
1. The market is already developing in such a manner that building sustainability is considered to be increasing important as energy prices rise and environmental legislation becomes a real risk.

2. Appraisers, as professionals, have an ethical responsibility to society and should therefore further sustainable development where possible.

3. Poor or incomplete valuation as a result of neglecting sustainable features can lead to misallocation of capital.

4. Lack of awareness of the relationship between green building and building financials leads to inaccurate pricing.

However, current valuation methodology does not include specific considerations for sustainability. It is assumed that environmental and social factors are reflected in the market price or rent paid [8].

\subsection{Valuation Methods}

There are three common approaches to any building valuation: the cost approach, the sales comparison approach, and the income capitalization approach [8]. The cost approach relates market value to cost. The Appraisal Foundation defines the cost approach valuation as "the cost to replace or reproduce the property being appraised" [44]. This is challenging for energy retrofitted buildings since new technologies are being integrated into older buildings and these buildings would likely not reproduced as originally designed. The cost approach works best for new properties with up-to-date technologies and construction methods [8]. However, it should be noted that the cost approach would result in a higher value for an energy efficiency-retrofitted property since these retrofits require capital to implement [45].

The sales comparison approach uses other, similar buildings sales in the same market to estimate the value of the building. It involves comparing one property to another and adjusting for differences to arrive at a value [44]. It is most useful when there are a large number of similar properties having been recently sold in the same location. This method is perhaps not appropriate at this time for green building appraisal because of the relatively small number of green buildings and lack of comprehensive financial data surrounding the sale of this type of building [8].

Civil Engineering UNIVERSITY OF TORONTO
Value Impacts of Energy Efficiency Retrofits on Commercial Office Buildings in Toronto, Canada | 37 
The income capitalization approach, or investment approach, is used to measure the current value of the future benefits of owning a property using projected income $[8,44]$. In simplified form, the income capitalization approach takes the following form $[27,65]$ :

$$
\text { Value }=\frac{\text { Net Operating Income }}{\text { Capitalization Rate }}
$$

Therefore, anything affecting net operating income (NOI) will affect value. NOI is calculated by determining the gross revenues of the property and subtracting the operating expenses [65]. The capitalization rate is determined by the appraiser and accounts for risks [27,65]. It is essentially the expected rate of return (or discount rate) on a property investment; for appraisal purposes, capitalization rate is typically determined based on capitalization rates of similar properties $[69,70]$. The capitalization rate is a function of the location and the physical attributes of a property, as well as market conditions [65]. Capitalization rate is generally determined by analyzing multiple recent sales of similar properties to determine their capitalization rate by dividing net operating income by sales price as a substitute for value [71]. If there is insufficient sales data for similar properties, the appraiser must determine a capitalization rate through more subjective means to arrive at a value he or she believes is appropriate. A low capitalization rate (discount rate) reflects a lower risk premium, which increases overall value [70].

Figure 3-1 summarizes the variables that affect market value and should be considered when using the income capitalization approach to building valuation [65].

\begin{tabular}{|c|c|}
\hline $\begin{array}{ll}\text { Revenues } \\
\text { - } & \text { Space Absorption/Occupancy } \\
\text { - } & \text { Potential Market Rent } \\
\text { Additional Rent } \\
\text { Operating Costs } \\
\text { - Operating Expenses } \\
\text { - } \quad \text { Realty Taxes }\end{array}$ & $\begin{array}{cl}\text { Market Value } \\
\cdot & \text { Capitalization Rate } \\
\cdot & \text { Internal Rate of } \\
& \text { Return/Terminal } \\
& \text { Capitalization Rate } \\
\text { - } & \text { NOI Performance }\end{array}$ \\
\hline
\end{tabular}

Figure 3-1- Variables Affecting Building Value [65]

The income capitalization approach is typically the primary valuation method for large commercial properties including office buildings [65]. It follows that, by using this method, sustainable and energy efficient buildings would be of higher value than conventional buildings by decreasing operating costs 
and increasing revenues for a higher overall NOI [45]. Further, sustainable and energy efficient buildings should inherently have less risk attached to their transactions, which lowers capitalization rate compared to conventional buildings and increases value.

Other, more complicated methods such as discounted cash flow analysis are also used to determine building value. Such methods are not used for this study because the income capitalization approach adequately illustrates the theoretical links between energy efficiency and building value; the income capitalization approach is simpler; and more complex methods require more detailed data than was available to support this research.

\subsection{Links between Sustainability and Value}

Using the hedonic pricing within the income capitalization approach is emerging as the preferred method for assessing the impact of sustainability on building value and therefore has been chosen for this study. A review of existing literature reveals theoretical links between specific sustainability features and building value. Table 3-1 summarizes these links. This is useful because features and effects can each be evaluated for their contributory value. As the scope of this research is on the relationship between energy efficiency and building value for existing buildings, only sustainability features applicable to building retrofits (not to new construction only) and to energy efficiency are presented here.

Understanding these theoretical links between building sustainability features and building value are essential to this research as retrofit case studies with energy and financial data are used to empirically observe these links. 
Table 3-1 - Links Between Sustainable Building Features and Value (Assembled and Adapted from [23, 45])

\begin{tabular}{|c|c|c|}
\hline Sustainability Feature & Impact & Link to Building Value \\
\hline HVAC system efficiency & $\begin{array}{l}\text { Reduces energy consumption } \\
\text { and costs. }\end{array}$ & $\begin{array}{l}\text { Reduces operating costs and } \\
\text { thereby increases NOI. } \\
\text { Reduces risks associated with } \\
\text { energy prices. }\end{array}$ \\
\hline Thermally efficient envelope & $\begin{array}{l}\text { Reduces unwanted heat } \\
\text { gain/loss and thus energy } \\
\text { consumption and costs. } \\
\text { Improves tenant comfort. }\end{array}$ & $\begin{array}{l}\text { Reduces operating costs and } \\
\text { thereby increases NOI. } \\
\text { Improves building quality. } \\
\text { Improves tenant experience, } \\
\text { positively affecting retention and } \\
\text { productivity. } \\
\text { Reduces risks associated with } \\
\text { energy prices and the indoor } \\
\text { environment. }\end{array}$ \\
\hline Daylighting & $\begin{array}{l}\text { Reduces electrical consumption } \\
\text { and costs. } \\
\text { Improves quality of indoor } \\
\text { environment. }\end{array}$ & $\begin{array}{l}\text { Reduces operating costs and } \\
\text { thereby increases NOI. } \\
\text { Improves tenant experience, } \\
\text { positively affecting retention and } \\
\text { productivity. } \\
\text { Reduces risks associated with } \\
\text { energy prices and the indoor } \\
\text { environment. }\end{array}$ \\
\hline Improved ventilation & $\begin{array}{l}\text { Improves quality of indoor } \\
\text { environment. }\end{array}$ & $\begin{array}{l}\text { Improves tenant experience, } \\
\text { positively affecting retention and } \\
\text { productivity. } \\
\text { Reduces risks associated with } \\
\text { the indoor environment. }\end{array}$ \\
\hline $\begin{array}{l}\text { Use of energy management } \\
\text { systems, monitoring, and } \\
\text { controls }\end{array}$ & $\begin{array}{l}\text { Ensures continual operational } \\
\text { optimization to reduce energy } \\
\text { consumption and costs. }\end{array}$ & $\begin{array}{l}\text { Reduces operating costs and } \\
\text { thereby increases NOI. } \\
\text { Reduces risks associated with } \\
\text { energy prices. }\end{array}$ \\
\hline $\begin{array}{l}\text { Operations and maintenance } \\
\text { (O\&M) staff training }\end{array}$ & $\begin{array}{l}\text { Realization of energy savings } \\
\text { through proper post-retrofit } \\
\text { building O\&M. }\end{array}$ & $\begin{array}{l}\text { Reduces operating and } \\
\text { maintenance costs and thereby } \\
\text { increases NOI. }\end{array}$ \\
\hline Tenant awareness/training & $\begin{array}{l}\text { Ongoing whole-building } \\
\text { involvement in sustainability and } \\
\text { energy use reduction. }\end{array}$ & $\begin{array}{l}\text { Reputational benefits for which } \\
\text { tenants are willing to pay a } \\
\text { premium in rent. } \\
\text { Retention of tenants seeking to } \\
\text { occupy sustainable spaces. }\end{array}$ \\
\hline Green building label & $\begin{array}{l}\text { Public knowledge of building } \\
\text { sustainability. }\end{array}$ & $\begin{array}{l}\text { Reputational benefits for which } \\
\text { tenants are willing to pay a } \\
\text { premium in rent. } \\
\text { Retention of tenants seeking to } \\
\text { occupy sustainable spaces. }\end{array}$ \\
\hline
\end{tabular}




\section{Case Studies}

The intent of the case studies was to determine whether Canadian Class $\mathrm{A}^{1}$ (or higher) commercial office buildings that have undergone recent retrofits experienced similar value benefits to those observed in previous empirical studies comparing green and conventional building types (discussed in Section 2.4). The study of buildings before and after retrofit can give a better representation of the relationship between building sustainability and value for the reasons listed below.

1. Green buildings are typically newer than non-green buildings. Therefore, they are more desirable from a tenant perspective regardless of the presence of sustainable features. This could lead to inflated results for value increases being improperly represented as consequences of building sustainability alone.

2. Comparing any building to another is difficult because controls for factors such as building location and height (which affect demand for a building) must be implemented. These factors do not vary for the comparison of a retrofitted building to its pre-retrofit state.

However, the case study approach also has disadvantages. Large-scale studies draw statistically significant conclusions whereas an in-depth analysis of a few case study buildings does not. Obtaining adequate data, particularly financial data, was the main limitation in carrying out this research. For the case studies, there were variations in the type and amount of data available, which limited the ability to compare buildings. The case studies that follow analyze retrofits of varying depths that achieved different results from energy and financial perspectives.

\subsection{Case Study Methodology}

Four case studies were selected for the analysis of the relationship between building energy efficiency and asset value. All of these buildings are located in downtown Toronto, Ontario. A questionnaire was developed to gather both qualitative and quantitative data. Unfortunately, no Canadian industry members participated in this survey because of confidentiality concerns regarding their financial data. The questionnaire was used as a template to organize data for each building from various sources. The questionnaire was developed to obtain all required information for the assessment of the relationship

\footnotetext{
${ }^{1}$ Buildings in Canada are classified according to physical characteristics, location, and tenant mix with Class AAA being the highest followed by Class AA, A, B, and C. A Class A building is defined as an "office building with higher quality combination of design, material, tenant mix, management, maintenance, improvements, amenities, age, size and location" [111].
} 
between energy efficiency improvements and asset value for a particular building. The questionnaire asks for not only the data types analyzed in the previous U.S. studies (rental rate, sales price, building age, height, location) but also for energy use data, retrofit details, and occupancy data. It is the author's hope that other researchers will use a form of this questionnaire in their own data pursuits. This template is located in Appendix A.

Toronto buildings were chosen because they were the only buildings for which enough data could be collected for the analysis that follows. Because of this data constraint, the scope of this study was narrowed from Canada to Toronto.

Energy data (particularly building performance data) and general building information were obtained through BOMA. Each of the buildings analyzed are BOMA BESt certified and had reported to BOMA on energy use among other sustainability features. These data were released on the condition that building specifics be kept confidential. Because of this confidentiality agreement, no building identifiers could be included in this study and certain reference material could not be disclosed. BOMA energy data are based on gross floor area when referred to by unit area.

The energy data contained in this thesis were not weather-normalized. Having obtained some of the energy data as aggregates from public sources, the breakdown of energy consumption and savings by energy type could not be determined, making weather-normalization impossible. This is a limitation to this thesis; however, the main findings are based not on energy data but on financial data.

Financial data were obtained through the Altus InSite market research database. The Altus InSite database contains current and historical data on all existing large office buildings in six of Canada's major markets [72]. Only publicly available data could be released - total building value, capitalization rates, and NOI could not be provided. However, occupancy data and rent data were available. Financial data were based on rentable office space when referred to by unit area. Raw data and detailed calculations are located in Appendix B. The following definitions describe the financial data analyzed in this study.

- Total additional rent includes operating and maintenance costs plus property taxes.

- Direct asking rate refers to the net rental rate.

- Total estimated direct rent is the sum of direct asking rate and total additional rent and is the tenant's rental charge.

Civil Engineering UNIVERSITY OF TORONTO
Value Impacts of Energy Efficiency Retrofits on Commercial Office Buildings in Toronto, Canada | 42 
- Total available area is the area of vacant office space available for lease.

- Occupancy rate is the percentage of office area that is occupied.

For certain buildings, operators provided occupancy data and/or operation and maintenance costs. Public sources such as property management websites and previously published reports on the case study buildings were also used to supplement this research.

Historical energy price data for Toronto were obtained from the Ontario Energy Board (OEB) for natural gas and Ontario's Independent Electricity System Operator (IESO) for electricity.

Once the data were obtained and compiled, trends were analyzed for each building over the years to determine whether any changes had occurred after the buildings had been retrofitted (Section 4.3 to 4.6). Trends were linked to building value where applicable. Building and retrofit descriptions have also been included for context. A global discussion of all results is located in Section 5.

\subsection{Market Conditions}

This section describes market conditions during the analysis periods so that building financial performance may be compared to and contrasted against downtown Toronto commercial office building market trends.

Figure 4-1 displays downtown overall occupancy rates for Toronto commercial office buildings from 2005 to 2014, inclusive. Occupancy rate is the percentage of office area that is occupied for a given year. Data were obtained from various sources, noted at the bottom of the figure.

Civil Engineering
Value Impacts of Energy Efficiency Retrofits on Commercial Office Buildings in Toronto, Canada | 43 


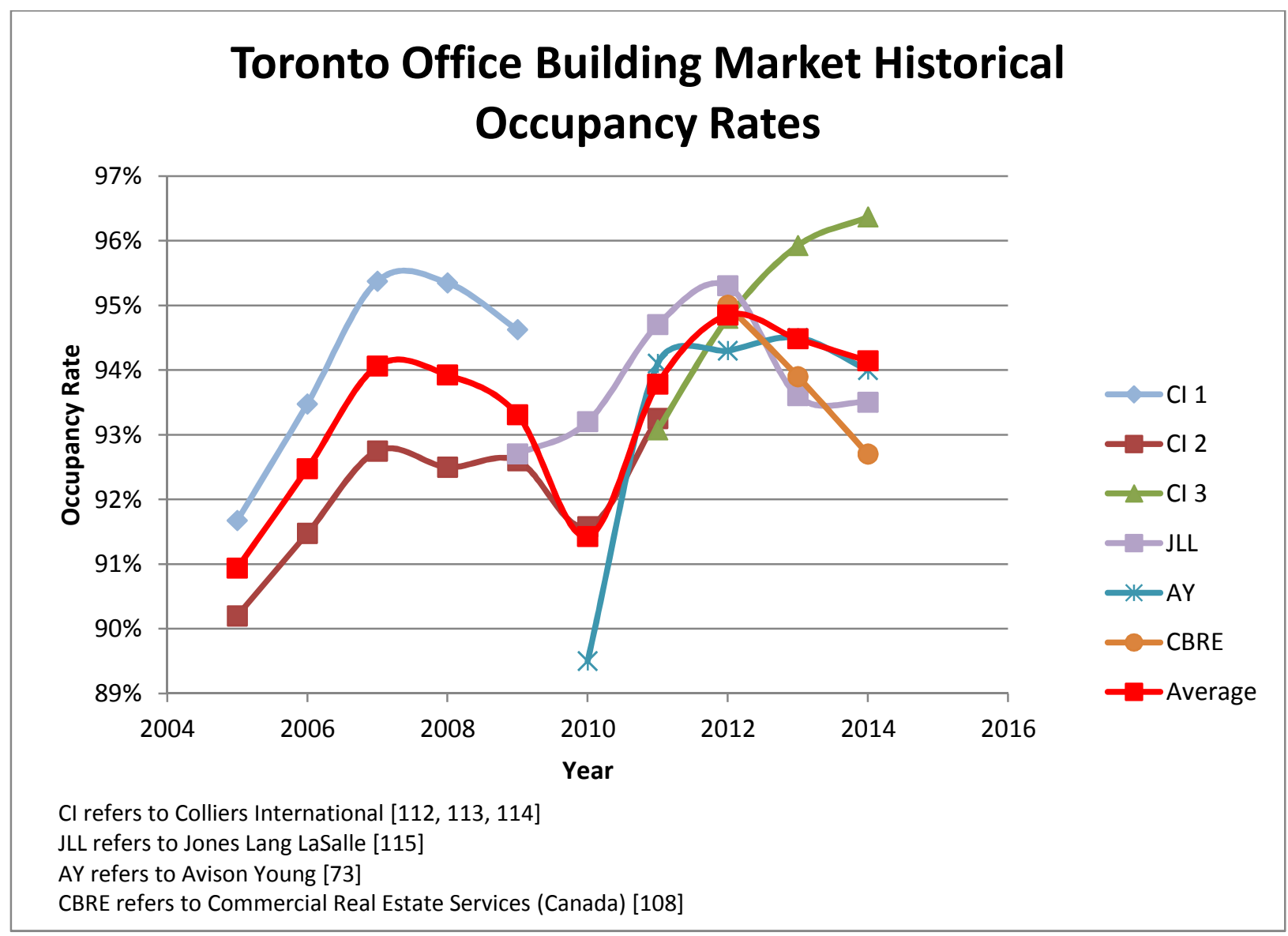

Figure 4-1 - Toronto Market Trend for Office Building Occupancy Rate

The average refers to the average of occupancy rate from all sources for a given year. Although the occupancy rates varied depending on which organization was reporting, the trend was an increase of about 3\%-4\% between 2005 and 2014. 2010 to 2014 occupancy rates were, for the Toronto downtown market, typically equal to or greater than 2005 to 2009 occupancy rates.

Figure 4-2 displays average rents for the downtown Toronto Class A office building market between 2010 and 2014. 


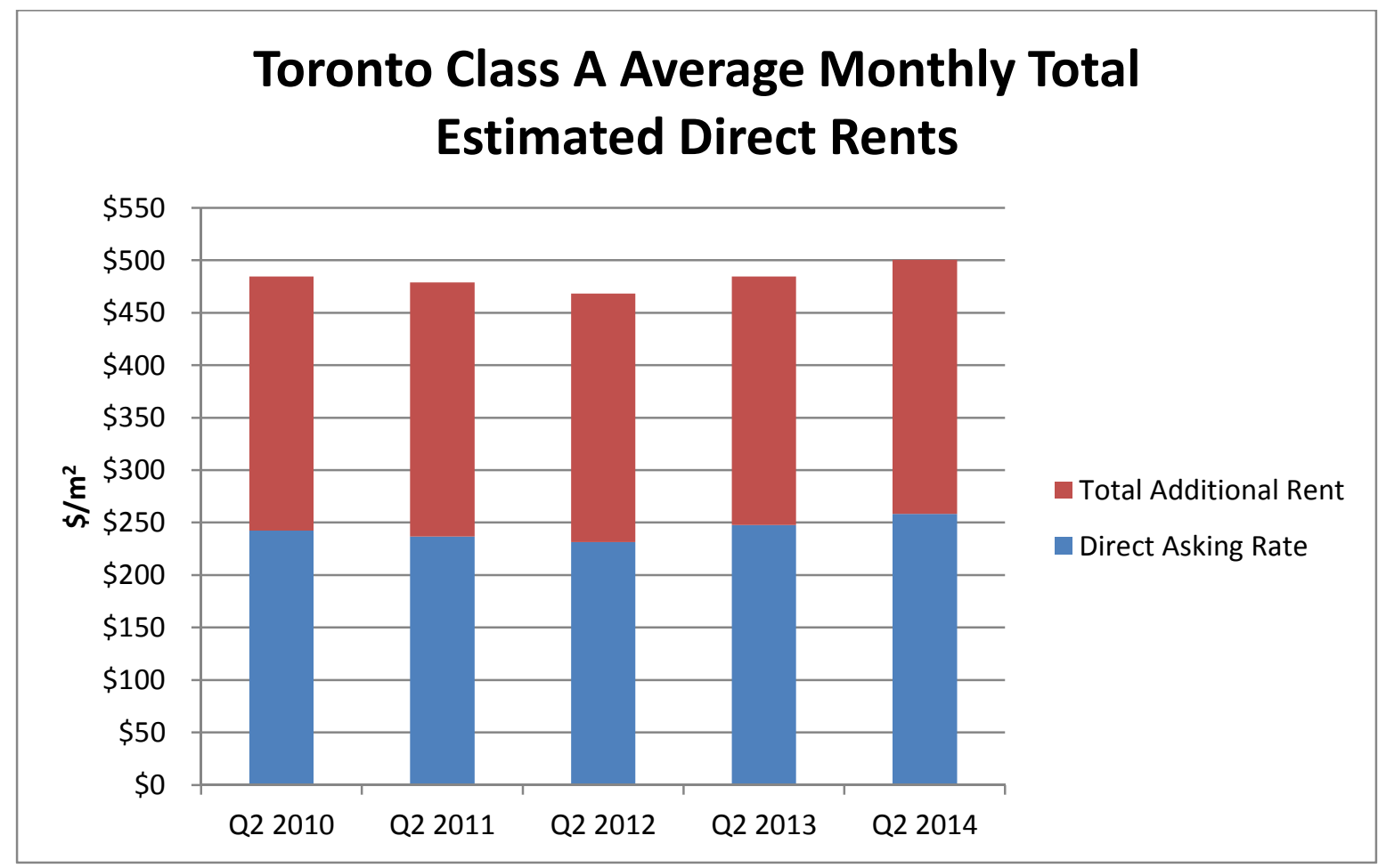

Figure 4-2 - Toronto Office Market Average Monthly Rents (Adapted from [73])

Total additional rent includes operating and maintenance costs plus property taxes. Direct asking rate refers to the net rental rate set by building management. Total additional rent and direct asking rate sum to total estimated direct rent, the tenant's rental charge. Note that on average downtown total additional rent and direct asking rate each make up about half of total estimated direct rent.

Table 4-1 summarizes the rental rates as read from Figure 4-2.

Table 4-1 - Downtown Toronto Office Building Market Average Rental Rates (Adapted from [73])

\begin{tabular}{cccc}
\hline Year & $\begin{array}{c}\text { Direct Asking } \\
\text { Rate }\left(/ \mathbf{m}^{2}\right)\end{array}$ & $\begin{array}{c}\text { Total Additional } \\
\text { Rent }\left(/ \mathbf{m}^{2}\right)\end{array}$ & $\begin{array}{c}\text { Total Estimated } \\
\text { Direct Rent }\left(/ \mathbf{m}^{2}\right)\end{array}$ \\
\hline Q2 2010 & $\$ 242$ & $\$ 242$ & $\$ 484$ \\
\hline Q2 2011 & $\$ 237$ & $\$ 242$ & $\$ 479$ \\
\hline Q2 2012 & $\$ 231$ & $\$ 237$ & $\$ 468$ \\
\hline Q2 2013 & $\$ 247$ & $\$ 237$ & $\$ 484$ \\
\hline Q2 2014 & $\$ 258$ & $\$ 242$ & $\$ 500$ \\
\hline
\end{tabular}

Market average total additional rent was constant in 2010 and 2011, dropped by about 2\% in 2012 and remained constant in 2013, then rose by about 2\% in 2014. 


\subsection{Building $\mathrm{A}$}

\begin{tabular}{ll}
\hline Building Location: & Toronto Financial District \\
\hline Building Class: & A or higher [74] \\
\hline Year Built: & $1975[74]$ \\
\hline Building Storeys: & $>50[74]$ \\
\hline Gross Floor Area: & $\sim 325,000 \mathrm{~m}^{2}\left(3,498,270 \mathrm{ft}^{2}\right)[74]$ \\
\hline Total Office Area: & $\sim 213,068 \mathrm{~m}^{2}\left(2,293,449 \mathrm{ft}^{2}\right)[75]$ \\
Building Occupants: & $>8,000[76]$ \\
\hline Retrofit Year: & 2009 \\
\hline Green Certifications: & BOMA BESt Level 3 (2010) \\
& LEED EB:O\&M Gold (2012) \\
\hline
\end{tabular}

\section{Structural Systems}

Building A's envelope construction consists of structural steel with curtain wall and double-paned windows [76]. Floors are column free with poured concrete slabs on metal pan with utilities running underneath.

\section{Mechanical Systems}

The pre-retrofit HVAC system was a central plant with induction units at the perimeter of the office tower floors and a constant volume air distribution system for the interior supplied from a fan located on each floor [77]. Outside air was being supplied from central fans and heat was supplied from heat recovery chillers with natural gas fired boilers as a backup supply [76].

\section{Electrical Systems}

The lighting systems in Building A had been updated prior to the 2009 retrofit to include compact fluorescent (CFL) lighting with dimmable ballasts and light-emitting diode (LED) exit signs throughout the building [76]. Lighting is controlled though the building automation system (BAS) which turns office floor lighting on and off based on tenant schedules and needs [76].

\subsubsection{Building A Retrofit Description}

Building A underwent an extensive retrofit in 2009. The motivations for the retrofit were [74]:

- most importantly, developing and maintaining a positive relationship between the building owner/operator and existing and prospective tenants; 
- the deterioration of the existing façade and need for replacement;

- tenant corporate social responsibility (CSR) requirements;

- the continuing ability to compete with new construction in the office building sector; and

- reduced energy consumption, which was considered but was not the major factor in retrofit investment decisions, possibly as a result of the low price of energy in Canada.

The retrofit of Building A cost of $\$ 17$ million for mechanical and electrical upgrades $[74,78]$.

Nine new, high-performance chillers with a total cooling capacity of 9,500 tons that recover heat from the existing cooling systems replaced the nine existing chillers that had a total cooling capacity of 9,400 tons [78]. These high performance chillers save energy by producing the same output more efficiently. The old chillers used R-11 refrigerant, a chlorofluorocarbon (CFC) refrigerant that contributes to ozone layer depletion and has been targeted for phase-out in Canada. The new chillers use R-123 refrigerant, a hydrochlorofluorocarbon (HCFC) with lower ozone depletion and global warming potentials [79].

Heating plant upgrades included:

- the replacement of existing boilers with new, high efficiency condensing boilers;

- the retrofit and recalibration of perimeter induction systems to operate as a variable volume system with heat recovery, improved controls, and high efficiency direct digital control (DDC) systems; and

- the addition of automatic vent dampers to restrict heat loss up chimneys $[74,78,80]$.

Heat recovery was achieved in two ways. Firstly, six of the new chillers are heat reclaim chillers and their waste heat is used to preheat domestic hot water (DHW) [74]. Secondly, washroom exhaust air heat is recovered to heat incoming ventilation air [74].

Building retro-commissioning also occurred at the time of the retrofit as a requirement for Building A's LEED EB:OM application [80]. Retro-commissioning refers to the process through which existing building system operation is optimized. Retro-commissioning may include items like equipment calibration, control optimization, equipment schedule changes, and review of original design intent to determine whether building load requirements have changed.

Civil Engineering UNIVERSITY OF TORONTO
Value Impacts of Energy Efficiency Retrofits on Commercial Office Buildings in Toronto, Canada | 47 
Many ongoing maintenance recommendations were made for Building A during the retrocommissioning process, including a regular maintenance schedule for mechanical systems. It was determined that such a maintenance schedule should include [81]:

- boiler efficiency measurement;

- ventilation and cooling control operation and set point checks;

- temperature and humidity control and set point checks;

- observation and analysis of energy use to identify areas of potential waste;

- air grille and diffuser cleaning;

- filter replacement;

- refrigerant leak checks; and

- $\quad$ preventive maintenance program adoption for all HVAC systems.

Retro-commissioning at the time of the retrofit also revealed other building optimization opportunities. Based on retro-commissioning findings, system controls were improved throughout Building $A$. A full building automation system (BAS) was implemented to control the building [81]. Pneumatic controls were replaced by high efficiency DDC systems [76]. Building A has high thermal storage properties because of its size and consequently has a significant temperature lag. It was determined that office floor temperatures can be increased by $2^{\circ} \mathrm{C}$ and office lighting can be dimmed during peak time to reduce peak consumption without noticeably affecting occupant comfort [80]. Sensor calibration and replacement and operating schedule adjustments were carried out to ensure optimal building performance.

BAS tracks energy use and costs monthly as part of the ongoing observation and analysis of energy consumption at Building A [74].

Building $A^{\prime}$ 's ventilation systems were retrofitted to operate based on $\mathrm{CO}_{2}$ demand. High efficiency VFD (variable frequency drive) enabled motors on dedicated outdoor air fans ensure proper ventilation [82]. Retro-commissioning at the time of the retrofit revealed that exhaust air flow was too high and it was subsequently reduced and air balancing was performed. VFDs were also installed on HVAC pumps to reduce energy consumption [74].

Civil Engineering UNIVERSITY OF TORONTO
Value Impacts of Energy Efficiency Retrofits on Commercial Office Buildings in Toronto, Canada | 48 
To further reduce electrical consumption, one third of the light bulbs in all office fixtures were removed while proper lighting levels were maintained [82].

In addition to mechanical and electrical upgrades, envelope improvements were also carried out. Envelope retrofits involved the replacement of existing façade panels with new glass panels, sealing the thermal envelope, and adding horizontal blinds to windows throughout the building for improved occupant control of the indoor environment $[74,81]$. A complete lobby renovation was also included in the retrofit for aesthetic improvement.

As a part of this retrofit, Building A's management implemented several measures to ensure tenant involvement in ongoing energy efficiency. Electrical sub-metering provides tenants with incentive to conserve energy [81]. There are also digital media screens in building common areas to communicate sustainability-related messages and best practices to tenants [81]. Additionally, tenant meetings are held with the purpose of promoting collaboration between building managers and tenants with the goal of reducing overall building energy consumption [81].

As a result of this retrofit, Building A achieved BOMA BESt Level 3 in 2010 and LEED EB:OM Gold in 2012 [83].

\subsubsection{Building A Analysis}

Energy data for Building A was obtained through the BOMA BESt database (utility data) and through online public sources (retrofit-specific energy savings data). BOMA BESt utility data from June 2009 to May 2010 was used to establish a post-retrofit EUI of $466 \mathrm{ekWh} / \mathrm{m}^{2}$-year (1.68 GJ/m² -year) [81]. Refer to Appendix B for raw data and calculations. For the same year, total utility costs (natural gas and electricity) were approximately $\$ 10.5$ million or $\$ 40.43 / \mathrm{m}^{2}$ of gross floor area [81]. GHG emissions for the same period were estimated at $34,625 \mathrm{CO}_{2}$-equivalent tonnes $\left(\mathrm{tCO}_{2} \mathrm{e}\right)[81]$.

Several sources reported on the energy savings achieved through this building retrofit, including the Toronto Atmospheric Fund (TAF), CivicAction Alliance, and the property managers (Table 4-2).

Civil Engineering UNIVERSITY OF TORONTO
Value Impacts of Energy Efficiency Retrofits on Commercial Office Buildings in Toronto, Canada | 49 
Table 4-2 - Building A Retrofit Energy Savings Compared to 2009 Baseline, According to Various Sources

\begin{tabular}{lc}
\hline Source & Energy Savings \\
\hline TAF [77] & $13.8 \%$ \\
CivicAction Alliance [84] & $20 \%$ \\
Self-reported [83] & $32 \%$ \\
\hline
\end{tabular}

For the purposes of this analysis, the TAF savings calculation result will be carried forward as an in-depth case study was performed by TAF to arrive at this value. The other values come from less reliable sources with less transparency. The CivicAction Alliance value was taken from a press release and the self-reported value from the property manager's web site. Using the TAF value, it was possible to establish a pre-retrofit EUI of approximately $557 \mathrm{ekWh} / \mathrm{m} 2$-year $\left(2.00 \mathrm{GJ} / \mathrm{m}^{2}\right.$-year). TAF also calculated that, post-retrofit, Building A emitted about 27,000 tCO ${ }_{2} \mathrm{e}$ of $\mathrm{GHGs}$ less per year than pre-retrofit [77].

Financial data for Building A was obtained through the Altus InSite financial database and has been summarized in Table 4-3 [75].

Table 4-3 - Building A Financial Data Summary

\begin{tabular}{|c|c|c|c|c|c|}
\hline Year & $\begin{array}{c}\text { Direct Asking } \\
\text { Rate } \$ / \mathrm{m}^{2}\end{array}$ & $\begin{array}{l}\text { Total Additional } \\
\text { Rent }\left(\$ / \mathrm{m}^{2}\right)\end{array}$ & $\begin{array}{l}\text { Total Estimated } \\
\text { Direct Rent }\left(\$ / \mathrm{m}^{2}\right)\end{array}$ & $\begin{array}{l}\text { Total Available } \\
\text { Area }\left(\mathrm{m}^{2}\right)\end{array}$ & $\begin{array}{l}\text { Occupancy } \\
\text { Rate }\end{array}$ \\
\hline 2005 & $\$ 344.44$ & $\$ 316.46$ & $\$ 660.90$ & 14,334 & $93.3 \%$ \\
\hline 2006 & $\$ 344.44$ & $\$ 322.06$ & $\$ 666.50$ & 28,710 & $86.5 \%$ \\
\hline 2007 & $\$ 322.92$ & $\$ 323.78$ & $\$ 646.70$ & 13,598 & $93.6 \%$ \\
\hline 2008 & nd & $\$ 334.65$ & nd & 26,119 & $87.7 \%$ \\
\hline 2009 & $\$ 328.30$ & $\$ 333.25$ & $\$ 661.55$ & 32,097 & $84.9 \%$ \\
\hline 2010 & $\$ 293.32$ & $\$ 333.25$ & $\$ 626.57$ & 25,900 & $87.8 \%$ \\
\hline 2011 & $\$ 296.01$ & $\$ 320.76$ & $\$ 616.77$ & 29,892 & $86.0 \%$ \\
\hline 2012 & $\$ 330.99$ & $\$ 316.46$ & $\$ 647.45$ & 31,325 & $85.3 \%$ \\
\hline 2013 & $\$ 330.99$ & $\$ 316.46$ & $\$ 647.45$ & 25,746 & $87.9 \%$ \\
\hline 2014 & nd & $\$ 323.35$ & nd & 28,356 & $86.7 \%$ \\
\hline \multicolumn{6}{|c|}{ * nd indicates no data } \\
\hline
\end{tabular}

The 2008 direct asking rate was not provided therefore total estimated direct rent trends were not analyzed in detail. However, it was noted that direct asking rates dropped in the years after the retrofit (2010-2011) and have not yet increased back to 2006 levels. Keeping rental rates low makes a building more competitive in attracting tenants.

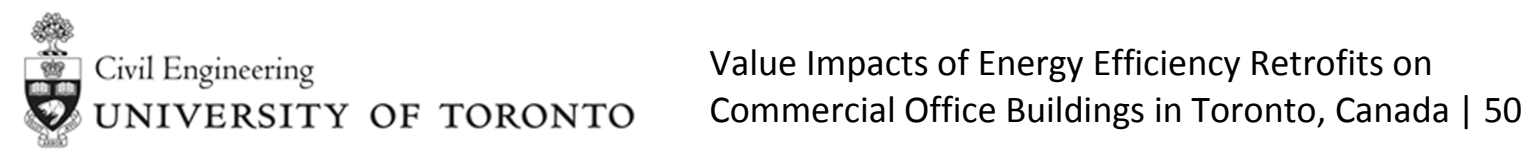


Total additional rent was provided for all years from 2005 to 2014, inclusive. Figure 4-3 illustrates total additional rent trends.

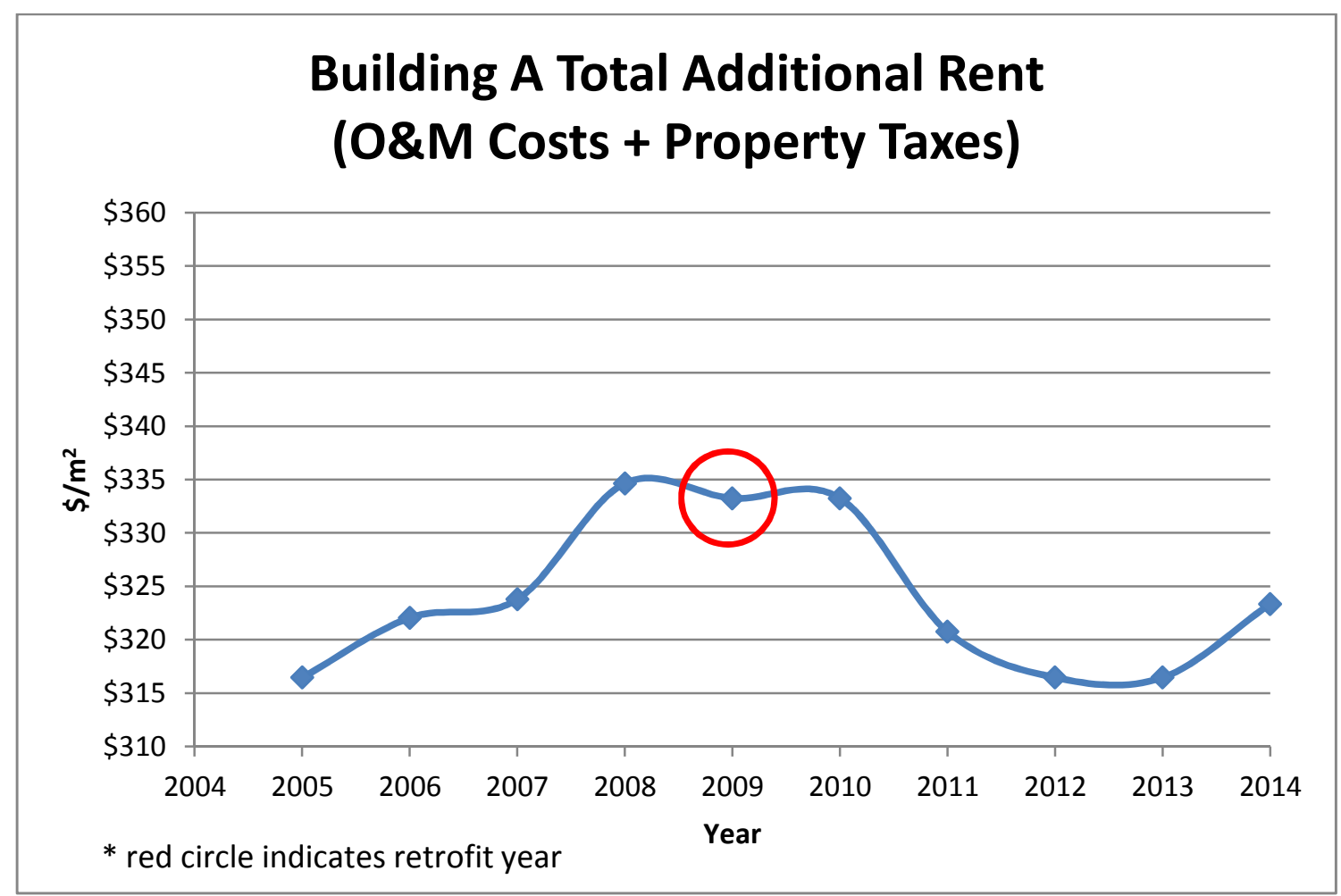

Figure 4-3 - Building A Total Additional Rent

Total additional rent was on the rise before Building A's 2009 retrofit and then dropped by 5\% $\left(\$ 16.79 / \mathrm{m}^{2}\right)$ between 2010 and 2012 as a result of energy savings achieved through the retrofit. After 2012 , total additional rent began to rise again, presumably because of rising energy costs. In 2013 , the price of electricity for buildings with interval metering through Ontario's Independent Electricity System Operator (IESO) like Building A rose by $17.6 \%$ and the price of natural gas supplied by Enbridge Gas Distribution rose by $24.4 \%$ [85, 86, 87]. Prior to 2013, Enbridge Gas Distribution natural gas prices were decreasing and IESO electricity prices were increasing more modestly. Increasing energy efficiency at Building A made it less dependent on the availability of energy and therefore less affected by energy price increases. Decreases in total additional rent indicate energy savings which decrease overall costs; if other appraisal factors were to remain constant, this would increase NOI and thus increase overall building value.

Figure 4-4 illustrates building occupancy between 2005 and 2014, inclusive. 


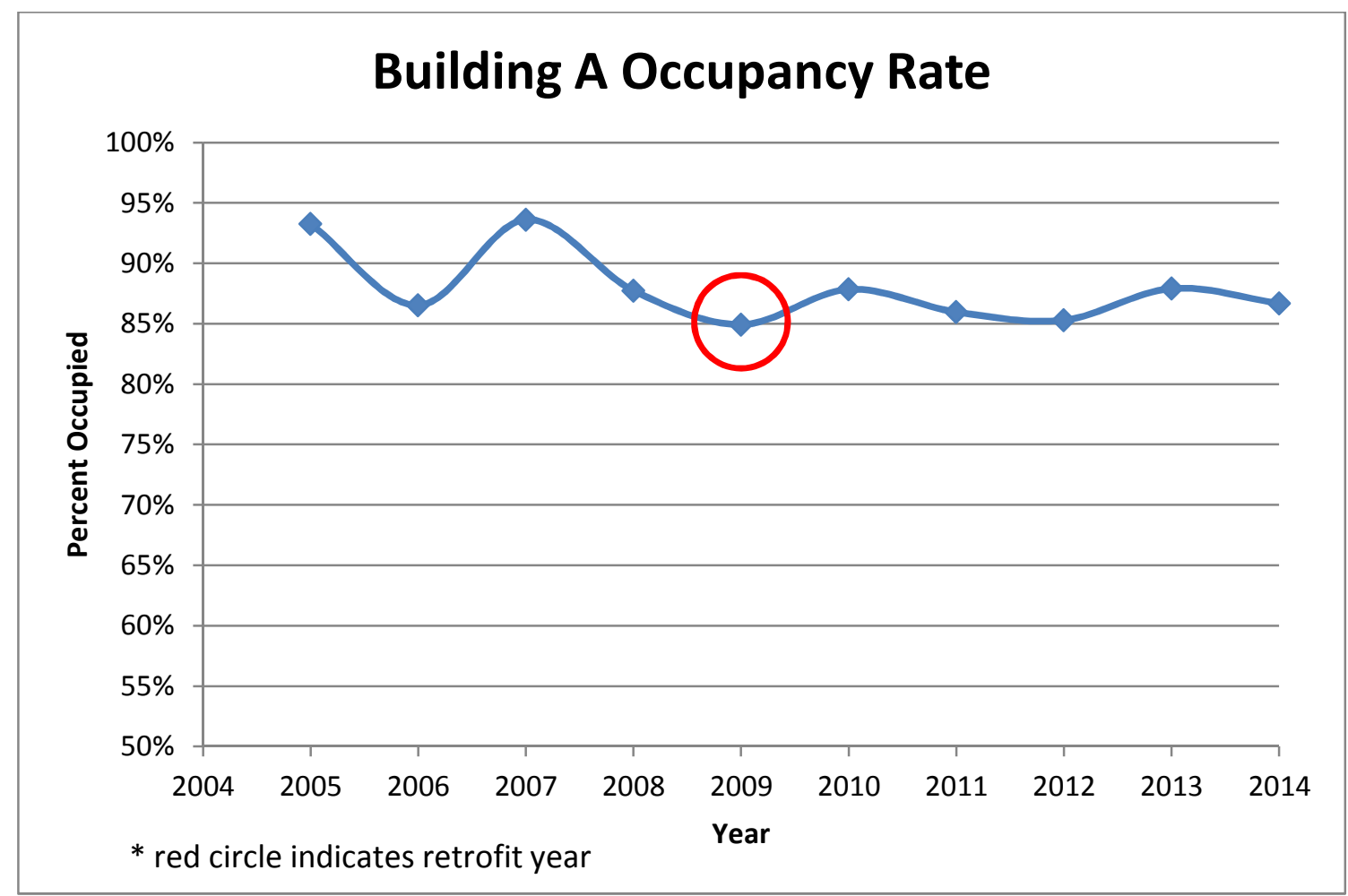

Figure 4-4 - Building A Occupancy Rate

Before the retrofit (2005 to 2009), Building A's occupancy ranged between approximately $85 \%$ and and 93.5\%; after the retrofit (2010 to 2014 ), occupancy ranged between approximately $85 \%$ and $88 \%$. In pre- and post-retrofit periods, occupancy oscillated from year to year, with about the same minimum value. However, pre-retrofit oscillation amplitude is three times as large as post-retrofit oscillation. Post-retrofit, Building A had a more consistent occupancy but also a lower occupancy on average. During the same time period, the overall occupancy rate for downtown Toronto office buildings increased (market occupancy trends discussed in further detail in Section 4.2).

Building A's occupancy trends did not follow the market overall and were lower post-retrofit than market averages. Thus, it does not appear as though the retrofit positively impacted occupancy rates in this case.

The building owner's rental revenue is determined by effective rent. Effective rent refers to how much of asking rent a property is actually converting to revenue, and is calculated using the following formula:

$$
\text { Effective Rent }=\text { Rent } \times \text { Occupancy Rate }
$$


The total estimated direct rental rate for Building A was missing for 2008. In lieu of analyzing effective total estimated direct rent, effective total additional rent analysis was performed. Building A's total additional rent made up between $47.2 \%$ and $53.2 \%$ of the total estimated direct rent between 2005 and 2013 (average of 49.9\%). Recall that the rest of the total estimated direct rent would be attributed to direct asking rate. Since the proportion of Building A's total estimated direct rent attributed to total additional rent was relatively stable, it was reasonably assumed that total estimated direct rent would follow the same trends as total additional rent.

Total additional rent rates were multiplied by their corresponding annual occupancy rates to yield effective total additional rent: about half of the rental revenue for the building (Figure 4-5).

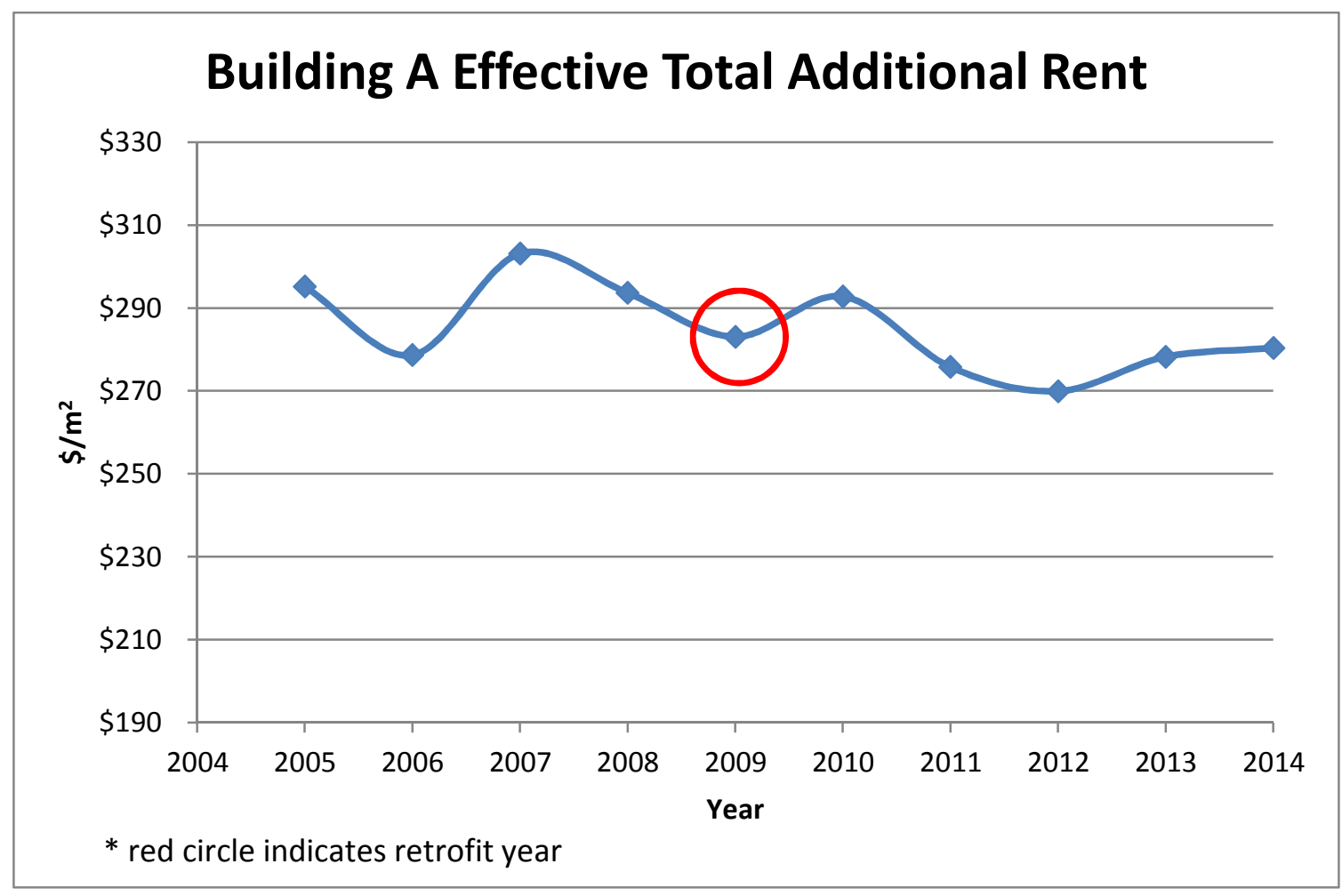

Figure 4-5 - Building A Effective Total Additional Rent

Building A's effective total additional rent was heavily influenced by occupancy rate and appears to follow a similar trend. Post-retrofit effective total additional rent is lower than pre-retrofit conditions even though $O \& M$ costs are lower because of increased vacancy rates. Total estimated direct rent (overall rental revenue) would follow a similar pattern. This translates directly to a decrease in NOI. 


\subsubsection{Building A Conclusions}

Building A's retrofit reduced overall annual energy consumption by approximately $13.8 \%(19,400,000$ ekWh or $2.69 \mathrm{GJ} / \mathrm{m}^{2}$-year) and reduced overall annual GHG emissions by $27,000 \mathrm{tCO}_{2} \mathrm{e}$. It was found that total additional rent (O\&M costs plus property tax costs) decreased after the retrofit as a result of energy efficiency improvements. Effective rental rates were heavily influenced by building occupancy, resulting in a decrease from pre-retrofit rates that negatively affected NOI.

\subsection{Building B}

\begin{tabular}{ll}
\hline Building Location: & Toronto Financial District \\
\hline Building Class: & A or higher [74] \\
\hline Year Built: & $1969[74]$ \\
\hline Building Storeys: & $40-50[74]$ \\
Gross Floor Area: & $\sim 132,000 \mathrm{~m}^{2}\left(1,440,0000 \mathrm{ft}^{2}\right)[88]$ \\
\hline Total Office Area: & $\sim 90,663 \mathrm{~m}^{2}\left(975,891 \mathrm{ft}^{2}\right)[89]$ \\
\hline Building Occupants: & $\sim 5,000[90]$ \\
Retrofit Year: & $2010-2011[74]$ \\
\hline Green Certifications: & LEED EB:OM Gold (2011) [74] \\
& BOMA BESt Level 3 (2012) [90] \\
\hline
\end{tabular}

\section{Structural Systems}

The original building envelope consisted of punched floor to ceiling single pane windows in concrete walls with metal plate spandrel panels [91].

\section{Mechanical Systems}

Building B has no boilers and uses no natural gas; heating is provided by the Enwave steam district heating network in downtown Toronto [90]. Steam provides all heating, hot water, and humidification. Building B also has no chillers; cooling is provided by deep lake water cooling from Lake Ontario. Deep lake water cooling was introduced in 2003 and eliminates the need for evaporative cooling towers [90]. Perimeter office air conditioning is achieved by perimeter in-floor induction systems with manual changeover; interior air conditioning is achieved by variable air volume (VAV) boxes [92]. Both the perimeter and interior systems receive fresh air from six central air handling units (AHUs) located in the mechanical rooms (there is one lower and one upper mechanical room). Air is supplied to zones through slotted light fixtures and ceilings serve as return-air plenums [91]. Dedicated fans exhaust air 
from washrooms, mechanical rooms, and parking areas. All HVAC and water systems are controlled through a BAS.

\section{Electrical Systems}

Toronto Hydro provides electricity to Building B. The building's lighting systems were upgraded in 2000 such that they were already high-efficiency before the $2010-2011$ retrofit [88]. The 2000 lighting upgrade included:

- lamp replacement with compact fluorescent (CFL) technology;

- addition of electronic ballasts to fluorescent fixtures;

- exit sign lamp replacement with LED technology;

- installation of occupancy sensors; and

- addition of automated lighting controls.

Building B's lighting system is controlled through a BAS. Base building hours are 7am to 8pm; lights are off outside of these hours unless otherwise requested by tenants [92].

\subsubsection{Building B Retrofit Description}

Building $B$ and Building $C$ are managed by the same company and were retrofitted together for an overall cost of approximately $\$ 110$ million in $2010-2011$ [74]. The retrofit took a year and a half to implement. The main motivations for this retrofit were:

- tenant demand;

- tenant retention; and

- corporate social responsibility (CSR) trends.

Energy consumption reduction was considered but was not a primary motivation; as previously discussed, low energy prices and lack of policy surrounding energy consumption disclosure makes energy use reduction a less pressing issue.

The Building B and Building C retrofits were similar in nature, were completed at the same time, and were undertaken by the same property management group with likely many of the same contractors. Their case studies, however, are separated as BOMA energy data and Altus InSite financial data were gathered for each of the buildings separately.

Civil Engineering UNIVERSITY OF TORONTO
Value Impacts of Energy Efficiency Retrofits on Commercial Office Buildings in Toronto, Canada | 55 
Building B's envelope underwent extensive upgrades during its 2010-2011 retrofit. All existing single pane windows were replaced with double paned insulated glass units (IGUs) to improve thermal efficiency [90]. These IGUs have low-emissivity (low-e) coatings to reduce radiant energy emission and thus reduce solar heat gain. In addition, these IGUs are argon-filled to lower thermal conductivity and tinted to reduce glare, thereby providing better views and a more comfortable work environment. Overall, these windows reduced steam and chilled water consumption through better insulation. Existing horizontal blinds were replaced by a new roller shade system to control unwanted heat gains [88]. These window upgrades generated energy savings and improve occupant comfort. All of the old window glass and metal frames were recycled in support of Building B's LEED EB:OM application [93].

The entire building façade was re-painted and sealed. This retrofit measure also improved the building's envelope by increasing thermal efficiency and keeping out precipitation.

Building B's elevators were refurbished during the 2010 - 2011 retrofit [94]. This particular retrofit measure was more for building aesthetics than anything else, but elevator lights were replaced with LEDs to contribute to overall lighting efficiency. Lobby areas were also refinished for aesthetic purposes.

Perimeter induction units were replaced and relocated in some cases to ceiling areas, thereby increasing the amount of usable floor space in the building and conserving energy through equipment efficiency improvement [94]. HVAC valves were replaced to improve the controllability of systems throughout the building and to decrease future valve maintenance issues. The valve replacement has since contributed to improved control of the thermal environment and consequently improved occupant comfort [94].

Advanced automation, control and monitoring equipment at the BAS level were implemented to allow building operators to optimize energy efficiency in real-time [94]. Mechanical systems are regularly maintained, audited, and commissioned to ensure proper functionality. The controls upgrade undertaken during this retrofit included the installation of a tenant electrical sub-metering system [88]. This provides tenants with the incentive and the data to reduce electrical consumption and reduce costs.

Building B's HVAC, lighting, elevator, and system upgrades had a capital cost of approximately \$33 million [74]. Through its 1.5-year retrofit Building B achieved a LEED EB:OM Gold certification and a BOMA BESt Level 3 certification with an overall score of $86 \%[74,88]$. To ensure ongoing and tenant involvement in sustainability efforts, the property management company initiated an occupant

Civil Engineering UNIVERSITY OF TORONTO
Value Impacts of Energy Efficiency Retrofits on Commercial Office Buildings in Toronto, Canada | 56 
engagement program and an online system through which tenants can track their energy use in realtime [74].

\subsubsection{Building B Analysis}

Energy data for Building B was obtained through the BOMA BESt database (utility data) and through online public sources (retrofit-specific energy savings data). BOMA BESt utility data from July 2009 to June 2010 was used to establish a pre-retrofit EUI of $343 \mathrm{ekWh} / \mathrm{m}^{2}$-year (1.24 GJ/m²-year) [90]. This energy consumption is attributed to $19,271,547 \mathrm{kWh}$ of electricity; 46,325 MBTU (42,937,173 pounds) of steam; and 10.3 GWh (3,145,170 ton-hours) of deep lake chilled water [88]. Refer to Appendix B for raw data and calculations. For the same year, total utility costs were approximately $\$ 3.7$ million or $\$ 28.36 / \mathrm{m}^{2}$ of gross floor area [90]. GHG emissions for the same period were estimated to be approximately $6,000 \mathrm{tCO}_{2} \mathrm{e}[90]$.

Energy savings were reported by the Toronto Atmospheric Fund (TAF) and the property managers. The property management company reported a 14\% reduction from 2008 levels in 2011 and an 18\% reduction from 2008 levels in 2013 for the retrofit of Building B and Building C together [77, 74]. Since these reported savings are for both buildings, they cannot necessarily be considered true for Building $B$ alone. These savings values are reported here to give the reader an idea of the level of savings achieved through this retrofit. In 2013, TAF reported a total of approximately 31 million ekWh in savings for Building B since the retrofit. The time elapsed was approximately 3 years, and so these savings were as high as $22.8 \%$ in 2013 for Building B (author's approximation).

Using a savings percentage of 18\%, the post-retrofit EUI would be approximately $281 \mathrm{ekWh} / \mathrm{m}^{2}$-year $\left(1.01 \mathrm{GJ} / \mathrm{m}^{2}\right.$-year). Annual utility cost savings were predicted by BOMA to be approximately $\$ 102,000$ [88]. These savings would decrease the utility cost index to $\$ 27.58 / \mathrm{m}^{2}$ of gross floor area $(2.7 \%$ utility cost savings).

Financial data for Building B was obtained through the Altus InSite financial database (rental rates, occupancy rates) and through the property manager (O\&M costs) [89]. The data provided have been summarized in Table 4-4.

Civil Engineering UNIVERSITY OF TORONTO
Value Impacts of Energy Efficiency Retrofits on Commercial Office Buildings in Toronto, Canada | 57 
Table 4-4 - Building B Financial Data Summary

\begin{tabular}{|c|c|c|c|c|c|}
\hline Year & $\begin{array}{l}\text { Direct Asking } \\
\text { Rate } \$ / \mathrm{m}^{2}\end{array}$ & $\begin{array}{l}\text { Total Additional } \\
\text { Rent }\left(\$ / \mathrm{m}^{2}\right)\end{array}$ & $\begin{array}{c}\text { Operating Costs } \\
\left(\$ / \mathrm{m}^{2}\right)\end{array}$ & $\begin{array}{l}\text { Total Estimated } \\
\text { Direct Rent }\left(\$ / \mathbf{m}^{2}\right)\end{array}$ & $\begin{array}{l}\text { Occupancy } \\
\text { Rate }\end{array}$ \\
\hline 2005 & $\$ 322.92$ & $\$ 325.61$ & nd & $\$ 648.52$ & $89.9 \%$ \\
\hline 2006 & $\$ 333.68$ & $\$ 325.61$ & nd & $\$ 659.29$ & $60.2 \%$ \\
\hline 2007 & $\$ 333.68$ & $\$ 336.05$ & nd & $\$ 669.73$ & $61.7 \%$ \\
\hline 2008 & $\$ 333.68$ & $\$ 345.52$ & $\$ 145.74$ & $\$ 679.20$ & $84.3 \%$ \\
\hline 2009 & $\$ 333.68$ & $\$ 340.68$ & $\$ 144.13$ & $\$ 681.35$ & $73.9 \%$ \\
\hline 2010 & nd & $\$ 340.68$ & $\$ 143.16$ & nd & $62.0 \%$ \\
\hline 2011 & nd & $\$ 340.68$ & $\$ 143.70$ & nd & $71.4 \%$ \\
\hline 2012 & $\$ 320.23$ & $\$ 342.29$ & $\$ 152.31$ & $\$ 662.52$ & $94.6 \%$ \\
\hline 2013 & $\$ 322.92$ & $\$ 353.06$ & $\$ 161.57$ & $\$ 675.97$ & $92.8 \%$ \\
\hline 2014 & nd & $\$ 353.06$ & $\$ 176.53$ & nd & $92.9 \%$ \\
\hline \multicolumn{6}{|c|}{ * nd indicates no data } \\
\hline
\end{tabular}

Direct asking rates were not provided in 2010, 2011, and 2014 therefore total estimated direct rent trends were not analyzed in detail. However, it was noted that direct asking rates dropped in the years after the retrofit (2010-2011) and have not yet increased back to 2006 levels. Keeping rental rates low makes a building more competitive in attracting tenants.

Total additional rent was provided for all years from 2005 to 2014, inclusive. Total additional rent includes $O \& M$ costs as well as property taxes. Operating cost data were obtained from the building operator from 2008 to 2014, inclusive. For these years, operating costs made up between $42.0 \%$ and $50.0 \%$ of total additional rent ( $44.1 \%$ on average). Since operating costs made up a relatively stable proportion of total additional rent prior to the retrofit, it was reasonably assumed that these proportions would have held from 2005 to 2007 as well. This assumption was made so that operating cost trends could be analyzed from 2005 to 2014, inclusive; operating costs would follow approximately the same trends year to year as total additional rent. Therefore, total additional rent data provided by Altus Insite were analyzed to determine whether the 2010-2011 retrofit had an impact on operating costs and thus on NOI. Figure 4-6 illustrates total additional rent trends. 


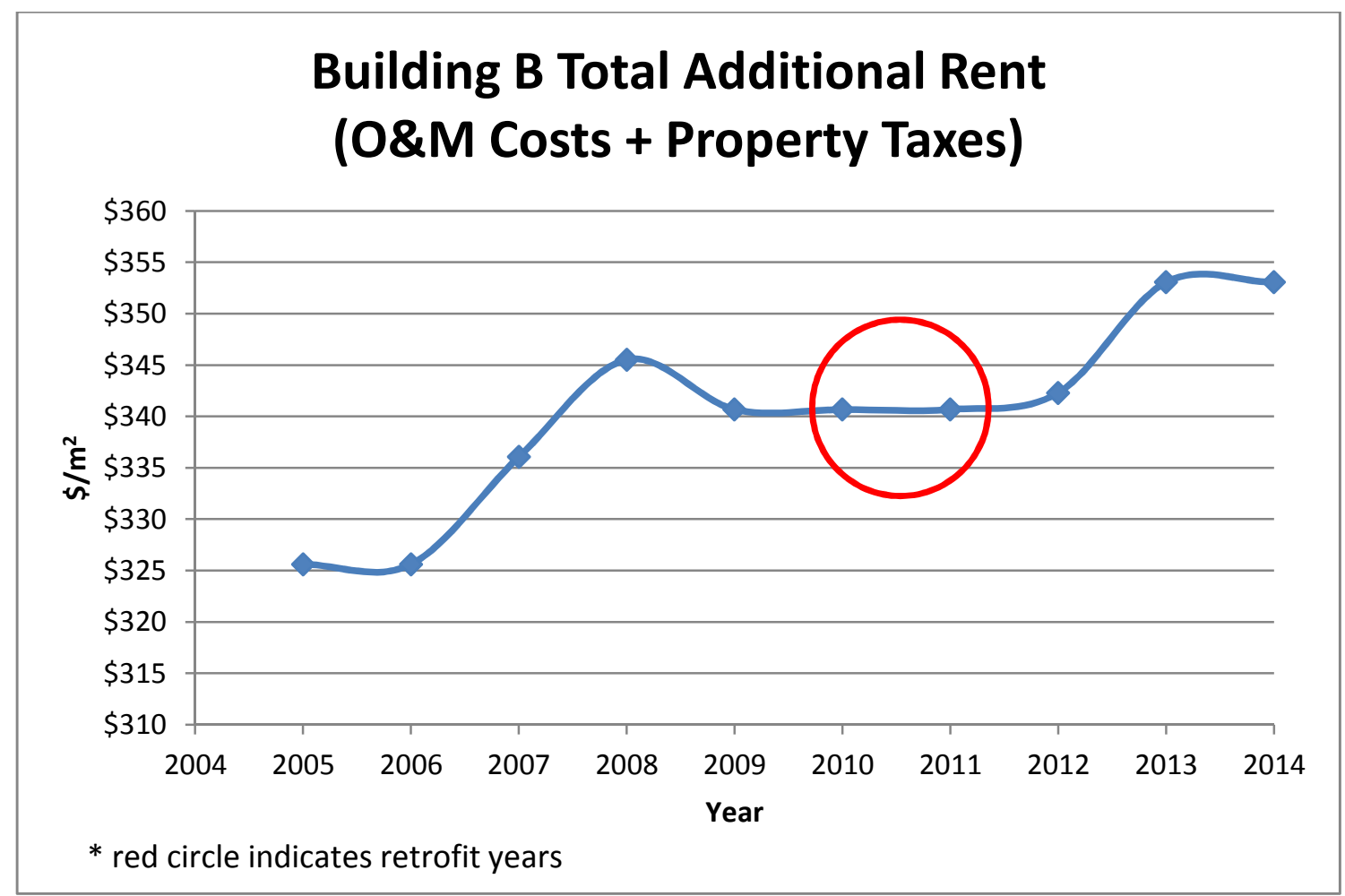

Figure 4-6 - Building B Total Additional Rent

Total additional rent was steadily rising before 2008 . Total additional rent dropped by $1.4 \%$ from 2008 to 2009 and remained relatively constant around $\$ 341 / \mathrm{m}^{2}$ for 2011 and 2012. In 2013, total additional rent rose by $3.1 \%$, presumably because of rising energy costs. In 2013 , the price of electricity for buildings with interval metering through Ontario's Independent Electricity System Operator (IESO) like Building B rose by $17.6 \%[85,87]$. Prior to 2013 , IESO electricity prices were increasing more modestly.

It is possible that the retrofit helped in keeping total additional rent constant from 2009 to 2012 through decreased utility spending. However, no definite conclusion can be made from this trend.

Occupancy data were also analyzed to analyze retrofit effects (Figure 4-7). 


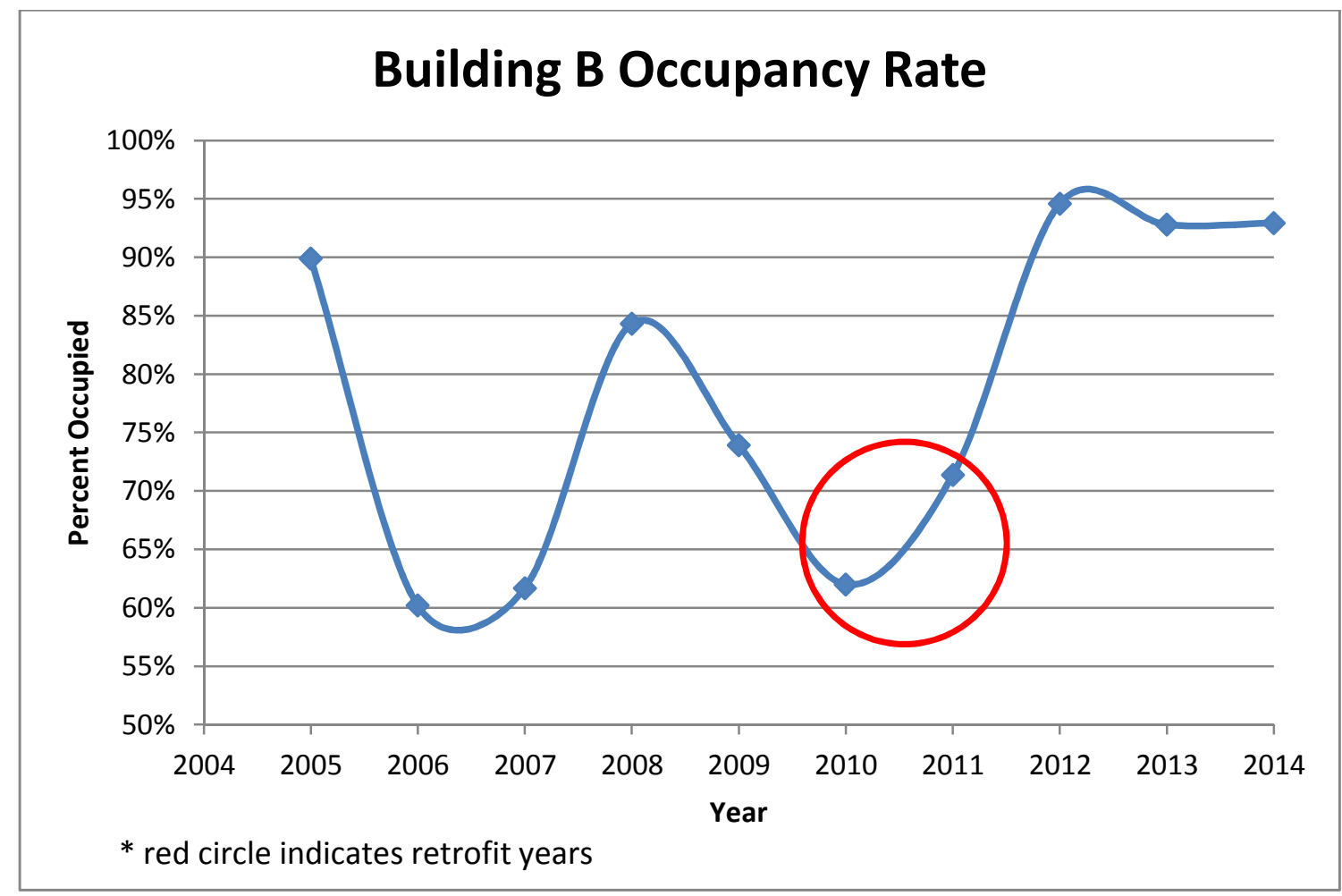

Figure 4-7 - Building B Occupancy Rate

Building B's occupancy rate ranged between approximately 60\% and 90\% between 2005 and 2011 (note the vertical axis on the figure above has a much greater range than for the other case studies). Large occupancy variances could be the result of one large tenant moving in or out.

Upon retrofit completion, occupancy evened out reaching its peak at 94.6\% in 2012 and then plateauing at $92.8 \%$. It appears as though post-retrofit occupancy is not only higher than pre-retrofit occupancy but also less volatile. Building B's occupancy rates at this time were approximately equal to the overall downtown Toronto market occupancy rate but had increased at a much higher rate than the market's overall rate had between 2010 and 2014 (Figure 4-1). Building B's significant occupancy rate increase can be attributed to the building's retrofit. Increased occupancy increases building revenue through rent, thereby positively affecting NOI and increasing value should other factors such as capitalization rate remain constant. Lowering occupancy rate volatility lowers ownership risk.

Total estimated direct rental rates for Building B were missing for retrofit years 2011 and 2010. In lieu of analyzing effective total estimated direct rent, effective total additional rent analysis was performed. Building B's total additional rent made up between $49.4 \%$ and $52.2 \%$ of the total estimated direct rent 
between 2005 and 2013 (average of 50.6\%). Recall that the rest of the total estimated direct rent would be attributed to direct asking rate. Since the proportion of Building B's total estimated direct rent attributed to total additional rent was relatively stable, it was assumed that total estimated direct rent would follow the same trends as total additional rent.

Total additional rent rates were multiplied by their corresponding annual occupancy rates to yield effective total additional rent: about half of the rental revenue for the building (Figure 4-8).

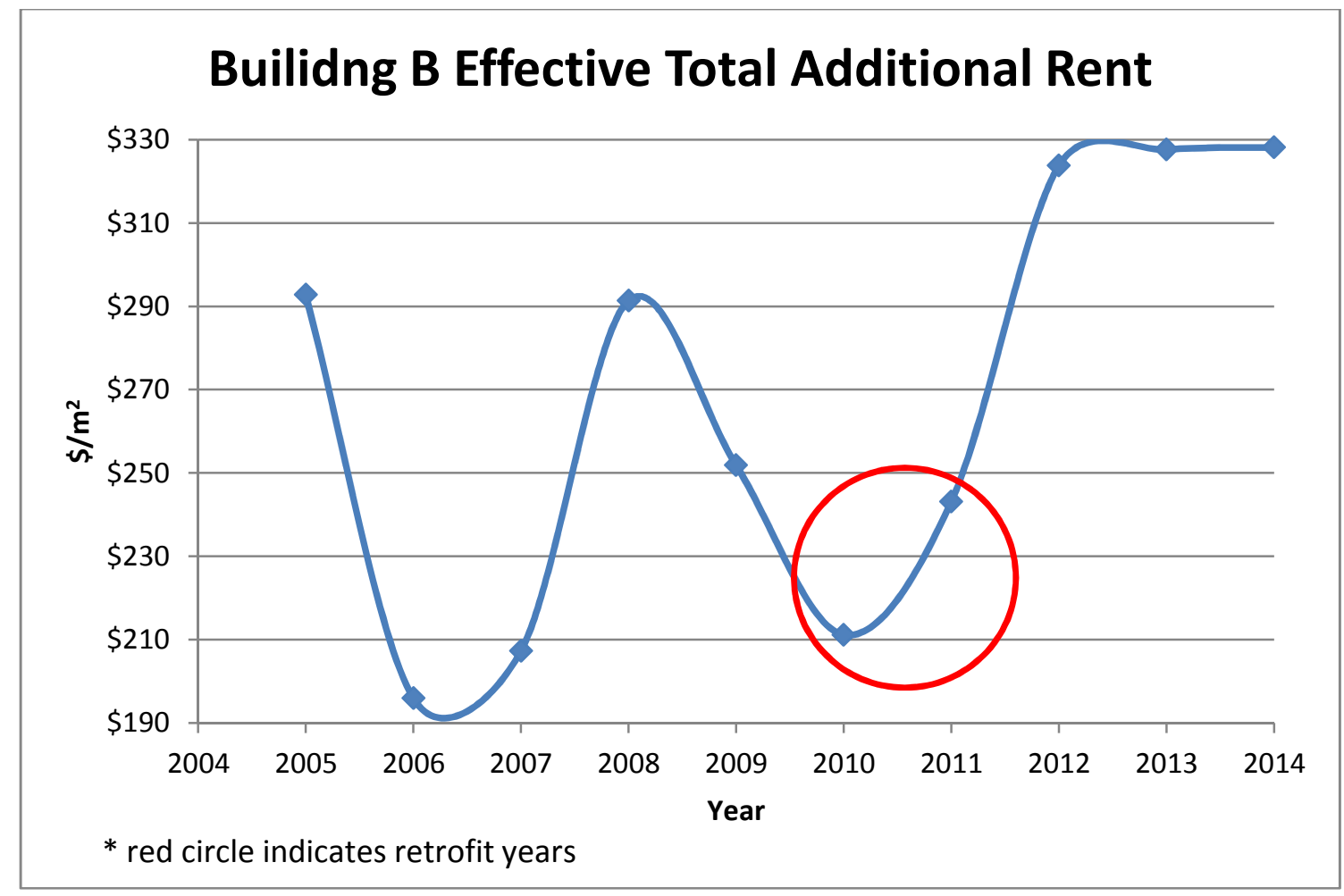

Figure 4-8 - Building B Effective Total Additional Rent

Building B's effective total additional rent was heavily influenced by occupancy rate and appears to follow a similar trend.

Building B's effective total additional rental rate ranged between approximately $\$ 196 / \mathrm{m}^{2}$ and $\$ 293 / \mathrm{m}^{2}$ between 2005 and 2011. Upon retrofit completion, effective total additional rent rose and then plateaued at approximately $\$ 328 / \mathrm{m}^{2}$ in 2013 and 2014 - an increase of about 35\% over 2011 preretrofit effective total additional rent). It appears as though post-retrofit effective total additional rent is not only higher but also less volatile (similarly to occupancy rate). This directly translates into a higher 
NOI. When post-retrofit conditions were compared to peak pre-retrofit conditions (2008 data), the calculated increase in effective total additional rent was approximately $12.5 \%$.

\subsubsection{Building B Conclusions}

Building B and Building C's 2010-2011 retrofits reduced energy consumption by approximately $18 \%$ overall from 2008 levels in 2013 [77, 74]. Upon further analysis of Building B, it was determined that post-retrofit occupancy rates were higher than pre-retrofit rates and were also less volatile. Effective total additional rent increased by approximately $12 \%$ to $35 \%$ after the retrofit (an increase of up to $\$ 84.97 / \mathrm{m}^{2}$ ). It can be assumed that effective total estimated direct rent would follow the same trends as effective total additional rent, since total additional rent consistently made up approximately half of total estimated direct rent. This means that effective total estimated direct rent would also have increased by approximately $12 \%$ to $35 \%$ after Building B's retrofit.

\subsection{Building C}

\begin{tabular}{ll}
\hline Building Location: & Toronto Financial District \\
\hline Building Class: & A or higher [74] \\
\hline Year Built: & $1969[74]$ \\
Building Storeys: & $>50[74]$ \\
\hline Gross Floor Area: & $\sim 189,476 \mathrm{~m}^{2}\left(2,039,503 \mathrm{ft}^{2}\right)[95]$ \\
\hline Total Office Area: & $\sim 123,491 \mathrm{~m}^{2}\left(1,329,246 \mathrm{ft}^{2}\right)[96]$ \\
Building Occupants: & $\sim 5,500[95]$ \\
Retrofit Year: & $2010-2011[74]$ \\
\hline Green Certifications: & LEED EB:OM Gold (2011) [74] \\
& BOMA BESt Level 3 (2012) [97] \\
\hline
\end{tabular}

\section{Structural Systems}

The original building envelope consisted of punched floor to ceiling single-glazed windows in concrete walls with metal plate spandrel panels [91].

\section{Mechanical Systems}

Building $\mathrm{C}$ has no boilers and uses no natural gas; heating is provided by the steam district heating network in downtown Toronto [95]. Steam provides all heating, hot water, and humidification. Building $\mathrm{C}$ also has no chillers; cooling is provided by deep lake water cooling from Lake Ontario. Deep lake water cooling was introduced in 2003 and eliminates the need for evaporative cooling towers [95].

Civil Engineering UNIVERSITY OF TORONTO
Value Impacts of Energy Efficiency Retrofits on Commercial Office Buildings in Toronto, Canada | 62 
Perimeter office air conditioning is achieved by perimeter in-floor induction systems with manual changeover; interior air conditioning is achieved by variable air volume (VAV) boxes [92]. Both the perimeter and interior systems receive fresh air from the eight central air handling units (AHUs) located in the mechanical rooms (there is one lower and one upper mechanical room). Air is supplied to zones through slotted light fixtures and ceilings serve as return-air plenums [91]. Dedicated exhaust fans exhaust air from washrooms, mechanical rooms, and parking areas. Mechanical systems including AHUs, fans, pumps, and VAV boxes are operated through a BAS [98].

\section{Electrical Systems}

Toronto Hydro provides electricity to Building C. Prior to the 2010 - 2011 retrofit, Building C's lighting was already provided by high-efficiency systems; the majority of fixtures have compact fluorescent bulbs and electronic ballasts, exit signs have LEDs, and occupancy sensors and other automated lighting controls are being used to minimize waste [95].

Building C's lighting system is controlled through a building automation system (BAS). Base building hours are 7 am to $8 \mathrm{pm}$; lights are off outside of these hours unless requested by tenants.

\subsubsection{Building C Retrofit Description}

Building $B$ and Building $C$ are managed by the same company and were retrofitted together for an overall cost of approximately $\$ 110$ million in $2010-2011$ [74]. The retrofit took a year and a half to implement. The main motivations for this retrofit were:

- tenant demand;

- tenant retention; and

- $\quad$ CSR trends.

Energy consumption reduction was considered but was not a primary motivation; as previously discussed, low energy prices and lack of policy surrounding energy consumption disclosure makes energy use reduction a less pressing issue.

The Building B and Building C retrofits were similar in nature, were completed at the same time, and were undertaken by the same property management group with likely many of the same contractors.

Civil Engineering UNIVERSITY OF TORONTO
Value Impacts of Energy Efficiency Retrofits on Commercial Office Buildings in Toronto, Canada | 63 
Their case studies, however, are separated as BOMA energy data and Altus InSite financial data were gathered for each of the buildings separately.

Building C's envelope underwent extensive upgrades during its 2010-2011 retrofit. These retrofits were identical to Building B's envelope retrofits - refer to the Building B case study for details. In short, existing single pane windows were replaced with double paned insulated glass units (IGUs) with lowemissivity coatings and a roller shade system was added [74, 95]. In addition, the entire building façade was re-painted and sealed like Building B's façade.

Elevators refurbishment, perimeter induction unit replacement and relocation, and valve replacement also occurred in the same fashion as the Building B retrofit.

Advanced automation, control and monitoring equipment at the BAS level were implemented to allow building operators to optimize energy efficiency in real-time [25]. Mechanical systems are regularly maintained, audited, and commissioned on an ongoing basis to ensure proper functionality. The controls upgrade undertaken during this retrofit also included the installation of a tenant electrical submetering system [95]. This provides tenants with the incentive and the data to reduce electrical consumption in order to reduce their own costs.

Building C's retrofit took approximately 1.5 years to complete. Through this retrofit, Building C achieved a LEED EB:OM Gold certification and a BOMA BESt Level 3 certification with an overall score of $84 \%$ [74, 97]. To ensure ongoing and tenant involvement in sustainability efforts, the property management company has initiated an occupant engagement program and an online system through which tenants can track their own energy use in real-time [74].

\subsubsection{Building C Analysis}

Energy data for Building $\mathrm{C}$ was obtained through the BOMA BESt database (utility data) and through online public sources (retrofit-specific energy savings data). BOMA BESt utility data from July 2009 to June 2010 was used to establish a pre-retrofit EUI of $444 \mathrm{ekWh} / \mathrm{m}^{2}$-year (1.60 GJ/m²-year) [97]. This energy consumption is attributed to $37,944,478 \mathrm{kWh}$ of electricity; $73,653 \mathrm{MBTU}(68,266,920$ pounds) of steam; and 37.9 GWh (6,331,800 ton-hours) of deep lake chilled water [95]. Refer to Appendix B for raw data and calculations. For the same year, total utility costs were approximately $\$ 6.6$ million or

Civil Engineering UNIVERSITY OF TORONTO
Value Impacts of Energy Efficiency Retrofits on Commercial Office Buildings in Toronto, Canada | 64 
$\$ 35.10 / \mathrm{m}^{2}$ of gross floor area [95]. GHG emissions for the same period were estimated to be approximately $11,800 \mathrm{tCO}_{2} \mathrm{e}[95]$.

Energy savings were reported by the property managers only. The property management company reported a 14\% reduction from 2008 levels in 2011 and an 18\% reduction from 2008 levels in 2013 for the retrofit of Building $B$ and Building $C$ together $[74,77]$. Since these reported savings are for both buildings, they cannot necessarily be considered true for Building $C$ alone. These savings values are reported here to give the reader an idea of the level of savings achieved through this retrofit.

Using a savings percentage of $18 \%$, the post-retrofit EUI would be approximately $364 \mathrm{ekWh} / \mathrm{m}^{2}$-year $\left(1.31 \mathrm{GJ} / \mathrm{m}^{2}\right.$-year). Annual utility cost savings achieved through retrofitting were predicted by BOMA to be approximately $\$ 352,600$ [95]. These savings would decrease the utility cost index to $\$ 33.24 / \mathrm{m}^{2}$ of gross floor area (5.3\% utility cost savings).

Financial data for Building C was obtained through the Altus InSite financial database (rental rates, occupancy rates) and through the property manager (operating costs) [96]. The data provided has been summarized in Table 4-5.

Table 4-5 - Building C Financial Data Summary

\begin{tabular}{|c|c|c|c|c|c|}
\hline Year & $\begin{array}{l}\text { Direct Asking } \\
\text { Rate } \$ / \mathrm{m}^{2}\end{array}$ & $\begin{array}{l}\text { Total Additional } \\
\text { Rent }\left(\$ / \mathrm{m}^{2}\right)\end{array}$ & $\begin{array}{l}\text { Operating Costs } \\
\left(\$ / \mathrm{m}^{2}\right)\end{array}$ & $\begin{array}{c}\text { Total Estimated } \\
\text { Direct Rent }\left(\$ / \mathrm{m}^{2}\right)\end{array}$ & $\begin{array}{c}\text { Occupancy } \\
\text { Rate }\end{array}$ \\
\hline 2005 & $\$ 301.39$ & $\$ 332.50$ & nd & $\$ 633.89$ & $97.7 \%$ \\
\hline 2006 & $\$ 333.68$ & $\$ 332.50$ & nd & $\$ 666.18$ & $97.6 \%$ \\
\hline 2007 & $\$ 333.68$ & $\$ 334.76$ & nd & $\$ 668.44$ & $96.1 \%$ \\
\hline 2008 & $\$ 333.68$ & $\$ 339.06$ & $\$ 145.53$ & $\$ 672.74$ & $84.9 \%$ \\
\hline 2009 & $\$ 333.68$ & $\$ 336.91$ & $\$ 142.62$ & $\$ 672.74$ & $84.9 \%$ \\
\hline 2010 & nd & $\$ 336.91$ & $\$ 142.62$ & nd & $86.6 \%$ \\
\hline 2011 & nd & $\$ 336.91$ & $\$ 143.91$ & nd & $90.8 \%$ \\
\hline 2012 & $\$ 333.68$ & $\$ 331.53$ & $\$ 151.34$ & $\$ 665.21$ & $93.4 \%$ \\
\hline 2013 & $\$ 333.68$ & $\$ 333.68$ & $\$ 155.11$ & $\$ 667.36$ & $96.2 \%$ \\
\hline 2014 & nd & $\$ 333.68$ & $\$ 161.46$ & nd & $95.2 \%$ \\
\hline \multicolumn{6}{|c|}{ * nd indicates no data } \\
\hline
\end{tabular}

Direct asking rates were not provided in 2010, 2011, and 2014 therefore total estimated direct rent trends were not analyzed in detail. However, it was noted that direct asking remained constant at $\$ 333.68 / \mathrm{m} 2$ from 2006 to 2009 and from 2012 to 2013. Avoiding raising asking rates makes a building more competitive in attracting tenants.

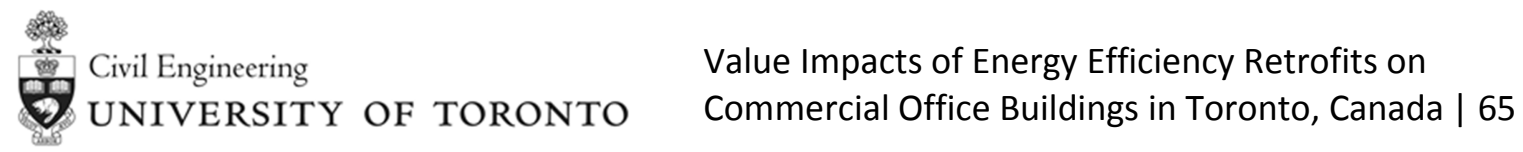


Total additional rent was provided for all years from 2005 to 2014, inclusive. Total additional rent includes O\&M costs as well as property taxes. Operating cost data were obtained from the building operator from 2008 to 2014, inclusive. For these years, operating costs made up between $42.3 \%$ and $48.4 \%$ of total additional rent ( $44.4 \%$ on average). Since operating costs made up a relatively stable proportion of total additional rent prior to the retrofit, it was reasonably assumed that these proportions would have held from 2005 to 2007 as well. This assumption was made so that operating cost trends could be analyzed from 2005 to 2014, inclusive; operating costs would follow approximately the same trends year to year as total additional rent. Therefore, total additional rent data provided by Altus Insite were analyzed to determine whether the 2010-2011 retrofit had an impact on operating costs and thus on NOI. Figure 4-9 illustrates total additional rent trends.

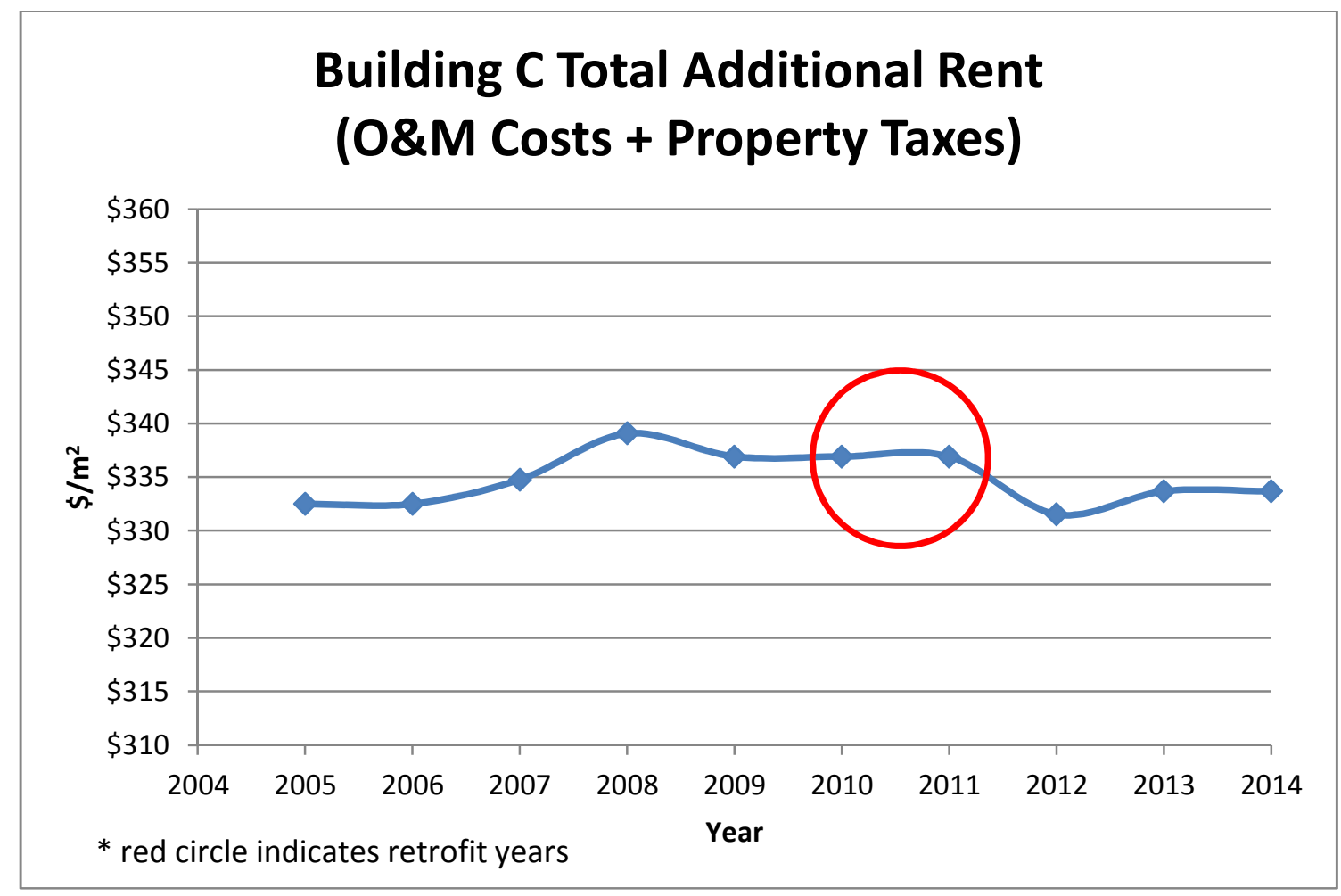

Figure 4-9 - Building C Total Additional Rent

Total additional rent was steadily rising before 2008 . Total additional rent would then drop by $0.6 \%$ in 2009 and plateau around $\$ 337 / \mathrm{m}^{2}$ for the retrofit period. After the 2010-2011 retrofit, total additional rent dropped by $1.6 \%$ to below 2005 levels in 2012 as a result of utility consumption reductions. Total additional rent increased by $0.6 \%$ in 2013 but remains below 2009 pre-retrofit levels. The 2013 increase can be explained by increases in energy prices during that year; in 2013, the price of electricity for 
buildings with interval metering through Ontario's Independent Electricity System Operator (IESO) like Building B rose by $17.6 \%[85,87]$. Prior to 2013 , IESO electricity prices were increasing more modestly. Through the analysis of Building $C$ total additional rent, it is apparent that retrofitting decreased O\&M costs. Decreases in O\&M costs decrease overall costs; if other appraisal factors were to remain constant, this would increase NOI and thus increase overall building value.

Occupancy data were also analyzed to uncover retrofit effects (Figure 4-10).

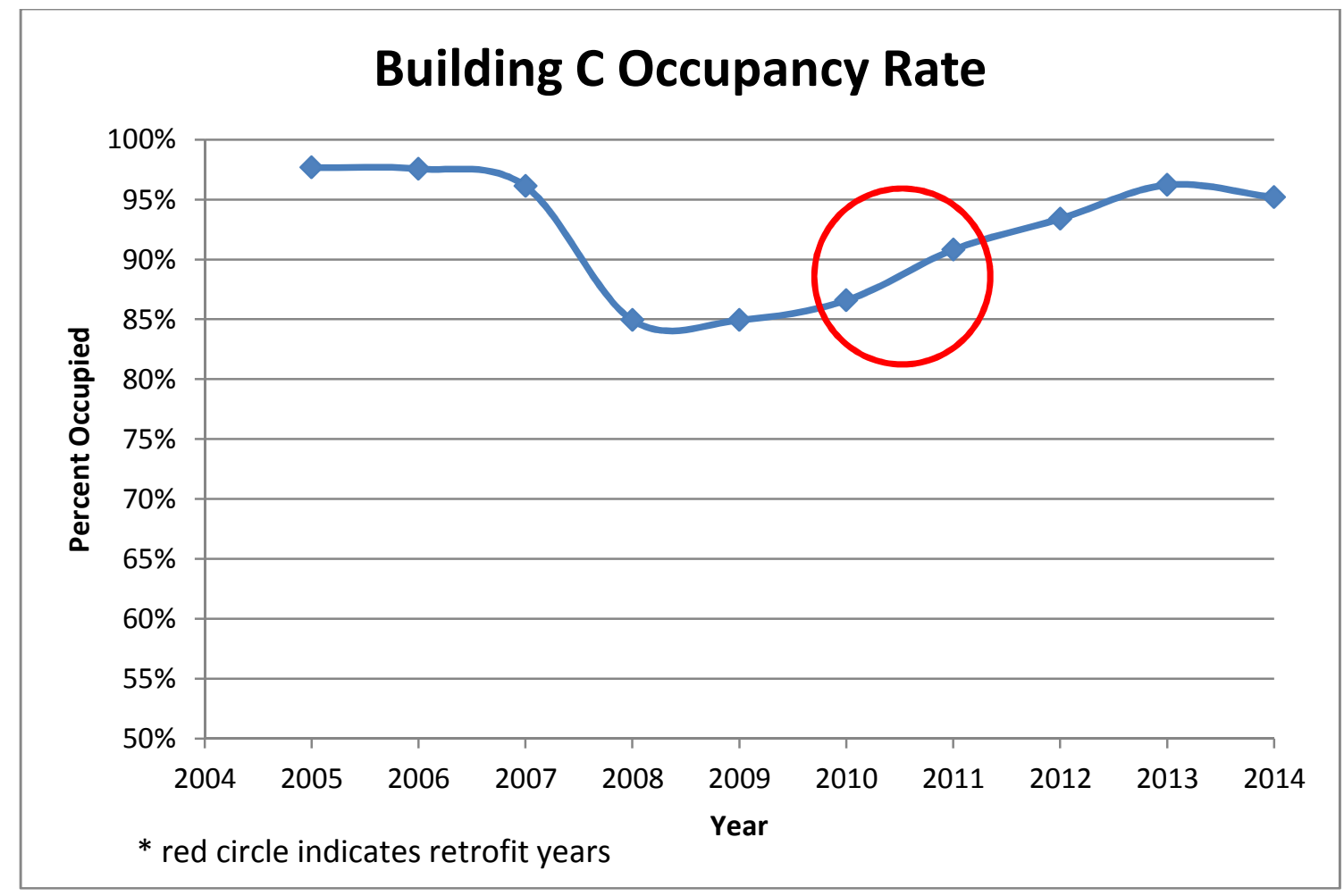

Figure 4-10 - Building C Occupancy Rate

Building C's occupancy rate was high (nearing 98\%) until it plummeted to approximately $85 \%$ in 2007/2008. This was the result of one major tenant moving out of the building [74]. Building $C$ took advantage of this vacancy to facilitate its retrofit in 2010 and 2011. After the retrofit, occupancy rates climbed steadily but have not yet reached 2005 levels. However, Building C's occupancy rates are on par with the overall downtown Toronto market occupancy rate in 2014 and the rate of occupancy increase was higher than the market's overall occupancy rate increase between 2008 and 2014 . This analysis of Building C's occupancy pattern reveals that retrofitting likely positively impacted occupancy 
rate through attraction of tenants to the improved facility and resulted in occupancy rate increases that exceeded those in the marketplace.

Total estimated direct rental rates for Building C were missing for retrofit years 2011 and 2010. In lieu of analyzing effective total estimated direct rent, effective total additional rent analysis was performed. Building C's total additional rent made up between $49.8 \%$ and $52.5 \%$ of the total estimated direct rent between 2005 and 2013 (average of 50.4\%). Since the proportion of Building C's total estimated direct rent attributed to total additional rent was relatively stable, it was assumed that total estimated direct rent would follow the same trends as total additional rent.

Total additional rent rates were multiplied by their corresponding annual occupancy rates to yield effective total additional rent: about half of the rental revenue for the building (Figure 4-11).

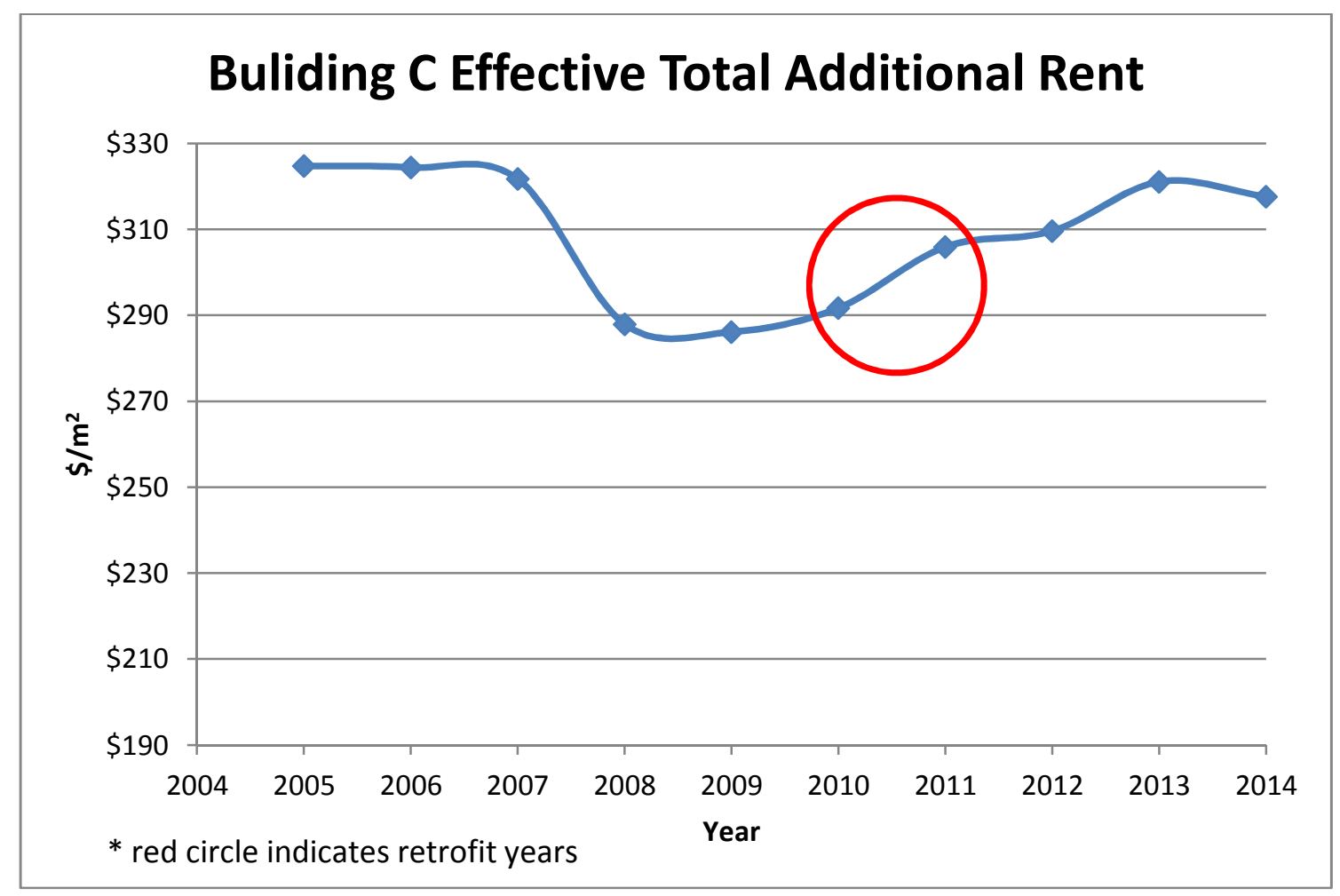

Figure 4-11 - Building C Effective Total Additional Rent

Building C's effective total additional rent was heavily influenced by occupancy rate and appears to follow a similar trend. 
Building C's effective total additional rent was stable from 2005 to 2007 until it plummeted 2008, coinciding with one major tenant moving out of the building [74]. Post-retrofit, effective total additional rent climbed steadily but has not yet reached 2005 levels. Still, analysis of this pattern reveals that retrofitting likely positively impacted effective rental revenue, thereby positively affecting NOI and increasing value should other factors such as capitalization rate remain constant. 2013 effective total additional rent was approximately 5\% higher than 2011 pre-retrofit effective total additional rent. However, this was still $1 \%$ lower than the 2005 effective total additional rent.

\subsubsection{Building C Conclusions}

Building B and Building C's 2010-2011 retrofits reduced energy consumption by approximately 18\% overall from 2008 levels in 2013 [74, 77]. Upon further analysis of Building C, it was determined that occupancy rates rose after the retrofit, possibly as a result of increased tenant attraction to the improved facility.

Total additional rent dropped below 2005 levels after retrofit completion. O\&M costs, following the same pattern, would have dropped significantly due to energy consumption reductions at Building C. Post-retrofit effective additional rent increased by approximately 5\% from 2011 to its peak in 2013. It was reasonably assumed that effective total estimated direct rent would follow the same trends. This means that effective total estimated direct rent would also have increased by approximately $5 \%$. However, effective total additional rent was 1\% lower in 2013 than in 2005.

\subsection{Building D}

\begin{tabular}{ll}
\hline Building Location: & Downtown Toronto \\
\hline Building Class: & A or higher [99] \\
\hline Year Built: & 1972 [99] \\
\hline Building Storeys: & $30-40[99]$ \\
\hline Gross Floor Area: & $40,133 \mathrm{~m}^{2}\left(431,990 \mathrm{ft}^{2}\right)[100]$ \\
\hline Total Office Area: & $38,274 \mathrm{~m}^{2}\left(411,976 \mathrm{ft}^{2}\right)[101]$ \\
\hline Building Occupants: & $\sim 1600[100]$ \\
\hline Retrofit Year: & $2010 / 2011$ \\
\hline Green Certifications: & BOMA BESt Level 2 (March 2012) \\
\hline
\end{tabular}




\section{Structural and Envelope Systems}

Building D's envelope is composed of pre-cast concrete and a curtain wall with single-pane windows [100]. The office tower is constructed of cast-in-place concrete one-way slabs supported by concrete beams, columns and walls [100]. The portion of the building located below the office tower is founded on cast-in-place concrete caissons bearing on undisturbed rock [100].

\section{Mechanical Systems}

Before the retrofit, typical office floors were served by two types of HVAC systems: a low pressure, constant volume, variable temperature reheat system which supplied conditioned air to the core areas through ceiling diffusers and a medium pressure constant volume system that supplied air to the perimeter induction units [99]. All HVAC equipment was controlled by pneumatic control systems original to the building [100].

\section{Electrical Systems}

Building D already had energy efficient lighting prior to its 2010/2011 retrofit; most building areas have compact fluorescent lighting and LED exit signs [100]. Building D has automated lighting controls as well as tenant controls [100].

\subsubsection{Building D Retrofit Description}

This retrofit description was referenced from several retrofit consultant reports as well as BOMA BESt reports with sources that cannot be disclosed for confidentiality reasons. Building D's retrofit was part of the building's capital upgrade plan and was much less extensive than the other three building case studies presented in this thesis. However, retrofit-specific information is more abundant for Building D than for other buildings because of the receipt of this information through consultant reports.

Building D's chilled water system was retrofitted in 2010/2011 as a part of the building's capital upgrade plan at a cost of $\$ 1,635,000$ before taxes $[102,103]$. The $2010 / 2011$ retrofit was a major cooling system retrofit involving $[103,104]$ :

- the replacement of the chillers;

- the replacement of condenser water pumps and the addition of variable frequency drives (VFDs) to these pumps; and 
- the addition of VFDs on chilled water pumps.

The existing chillers were installed in 1972 and were original to the building [102]. Cooling was being provided by one 705 ton and one 695 ton capacity centrifugal chillers [103]. These chillers provided chilled water to the cooling coils in the AHUs and the secondary piping circuit connecting to coils in the 2-pipe perimeter induction units. Manually operated seasonal switchover valves were used to control winter/summer switchover in the 2-pipe system. The chillers were piped in series with control valves to control and divert water flow through the chillers. The control valves also permitted sequencing of the lead chiller. According to building data logs, only one chiller was required to handle the cooling load of the building for most days. The chilled water setpoint is controlled through the BAS. Cooling tower fan motors have VFDs.

The original chillers were replaced with ten 85 ton water-cooled modular chillers for a total of 850 tons of cooling capacity [102]. Under this new configuration, the number of chillers operated at partial load varies from one chiller to ten chillers depending on building demand. This saves energy compared to the two-chiller system that would have a much higher capacity than building loads would require from its lead chiller at most times. Re-piping was required to accommodate the new chiller configuration and was included in the capital cost of this retrofit measure.

The replacement of the two existing chillers with ten new chillers was predicted to provide $189 \mathrm{~kW}$ demand savings and 189,000 kWh electrical consumption savings annually.

In addition to chiller replacement, the two condenser water pumps were also replaced and VFDs were added to each to convert the chilled water system from constant to variable flow. The existing condenser water pumps were $100 \mathrm{HP}$ each, and operated at a constant $2100 \mathrm{GPM}$ at 125 feet head $(132.5 \mathrm{~L} / \mathrm{s})$ at $38 \mathrm{~m})$ from the chillers to the cooling tower [102]. The new chiller system required much lower condenser water flow rate, 1400 GPM at 100 feet head ( $88.3 \mathrm{~L} / \mathrm{s}$ at $30.5 \mathrm{~m})$ [102]. The replacement of the two condenser water pumps and addition of VFDs was predicted to provide demand savings of $71.7 \mathrm{~kW}$ and consumption savings of $167,021 \mathrm{kWh}$ annually.

VFDs were also installed on chilled water pumps in the conversion of the chilled water building cooling system from constant to variable speed. The existing chilled water pumps were $40 \mathrm{HP}(30 \mathrm{~kW})$ each, and were operated at a constant 1200 GPM at 95 feet head $(75.7 \mathrm{~L} / \mathrm{s}$ at $29 \mathrm{~m})$ from the chillers to the building [102]. With the addition of the new VFDs, the pumps would be able to operate at a higher

Civil Engineering UNIVERSITY OF TORONTO
Value Impacts of Energy Efficiency Retrofits on Commercial Office Buildings in Toronto, Canada | 71 
efficiency or lower flow rate with a reduced current draw. The addition of VFDs to the chilled water pumps was predicted by the retrofit consultant to provide $5.1 \mathrm{~kW}$ demand savings and $20,000 \mathrm{kWh}$ electrical consumption savings annually.

The retrofit project also included the installation of a sophisticated cooling plant manager to constantly monitor the power consumption of power-consuming equipment, namely the chillers, cooling tower, primary chilled water pumps, and condenser pumps required to deliver chilled water through the building, and strategically set operating points for all equipment to best optimize plant efficiency [105]. Energy and flow meters were included in the controls installation to calculate the real time $\mathrm{kW} /$ ton ratio [105]. Differential pressure transmitters were included in the condenser water loop and chilled water loop to control VFD pump operation [105]. Motorized control valves were installed on the chiller evaporator and condenser inlets to control and direct flow through the chillers as dictated by the cooling plant manager [105].

It was noted by the retrofit consultant that the cooling tower was original to the building and was beyond its service life expectancy. The following conditions were observed [102]:

- Steel frame thinned due to corrosion;

- Supply and return pipes rusted and pitted;

- Filling stuffing collapsed.

However, replacement of the cooling tower was not included in this retrofit, presumably because of lack of capital.

In addition to the chilled water system retrofit, Building D management implemented a system for communicating with tenants/occupants regarding environmental initiatives and practices in the building [105]. The system is composed of "green team" meetings, quarterly newsletters, and lobby displays [105]. There are communications to tenants on the environmental measures that they can implement in the workplace to contribute to energy conservation and plug load reduction which could impact behaviour. However, behavioural impacts are difficult to quantify and therefore the tenant engagement system was not included in the retrofit consultant's energy savings calculations.

The following table summarizes the retrofit measures and projected resulting energy consumption and demand savings as reported by the retrofit consultant.

Civil Engineering UNIVERSITY OF TORONTO
Value Impacts of Energy Efficiency Retrofits on Commercial Office Buildings in Toronto, Canada | 72 
Table 4-6 - Projected Retrofit Savings [103]

\begin{tabular}{|c|c|c|c|c|c|c|}
\hline \multirow[t]{2}{*}{ Retrofit Measure } & \multicolumn{2}{|c|}{$\begin{array}{c}\text { Existing Chilled Water } \\
\text { System }\end{array}$} & \multicolumn{2}{|c|}{$\begin{array}{c}\text { Proposed Chilled Water } \\
\text { System }\end{array}$} & \multicolumn{2}{|c|}{$\begin{array}{l}\text { Projected Energy } \\
\text { Savings }\end{array}$} \\
\hline & $\begin{array}{l}\text { Demand } \\
(\mathrm{kW})\end{array}$ & $\begin{array}{l}\text { Consumption } \\
\text { (kWh) }\end{array}$ & $\begin{array}{l}\text { Demand } \\
\text { (kW) }\end{array}$ & $\begin{array}{l}\text { Consumption } \\
\text { (kWh) }\end{array}$ & $\begin{array}{l}\text { Demand } \\
\text { (kW) }\end{array}$ & $\begin{array}{c}\text { Consumption } \\
\text { (kWh) }\end{array}$ \\
\hline Chiller Replacement & 756 & 756,000 & 567 & 567,000 & 189 & 189,000 \\
\hline $\begin{array}{l}\text { Condenser Water } \\
\text { Pump Replacement + } \\
\text { VFDs }\end{array}$ & 137.8 & 320,971 & 66.1 & 153,950 & 71.7 & 167,021 \\
\hline $\begin{array}{l}\text { Chilled Water Pump } \\
\text { VFDs }\end{array}$ & 57.7 & 37,000 & 52.6 & 17,000 & 5.1 & 20,000 \\
\hline Total & & & & & 265.8 & 376,021 \\
\hline
\end{tabular}

Overall, the chilled water plant retrofit was projected to generate $376,021 \mathrm{kWh}$ annually in consumption savings and $265.8 \mathrm{~kW}$ in demand savings. The retrofit consultant estimated that these electricity savings would generate a cost savings potential of $\$ 124,000$ annually through operating and maintenance cost reductions post-retrofit.

\subsubsection{Building D Analysis}

Energy data for Building D was obtained through the BOMA BESt database (utility data) and a report by the retrofit consultant (retrofit-specific energy and cost data).

On June 1, 2011, a post-retrofit site visit was conducted to confirm energy saving results. Total measured savings were less than had been predicted by the retrofit consultant. Table 4-7 summarizes the actual energy savings generated by the retrofit as verified through the BOMA application process.

Table 4-7 - Measured Retrofit Savings [102]

\begin{tabular}{|c|c|c|c|c|c|c|}
\hline \multirow[t]{2}{*}{ Retrofit Measure } & \multicolumn{2}{|c|}{$\begin{array}{c}\text { Existing Chilled Water } \\
\text { System }\end{array}$} & \multicolumn{2}{|c|}{$\begin{array}{c}\text { Proposed Chilled Water } \\
\text { System }\end{array}$} & \multicolumn{2}{|c|}{ Actual Energy Savings } \\
\hline & $\begin{array}{c}\text { Demand } \\
\text { (kW) }\end{array}$ & $\begin{array}{l}\text { Consumption } \\
\text { (kWh) }\end{array}$ & $\begin{array}{l}\text { Demand } \\
\text { (kW) }\end{array}$ & $\begin{array}{l}\text { Consumption } \\
\text { (kWh) }\end{array}$ & $\begin{array}{c}\text { Demand } \\
\text { (kW) }\end{array}$ & $\begin{array}{c}\text { Consumption } \\
\text { (kWh) }\end{array}$ \\
\hline Chiller Replacement & 672 & 671,600 & 567 & 567,000 & 105 & 104,600 \\
\hline $\begin{array}{l}\text { Condenser Water } \\
\text { Pump Replacement + } \\
\text { VFDs }\end{array}$ & 133 & 207,400 & 66 & 103,700 & 67 & 103,700 \\
\hline $\begin{array}{l}\text { Chilled Water Pump } \\
\text { VFDs }\end{array}$ & 53 & 82,800 & 66 & 75,800 & -13 & 7,000 \\
\hline Total & & & & & 159 & 215,300 \\
\hline
\end{tabular}


Based on measurement and verification, the chilled water plant retrofit would generate $215,300 \mathrm{kWh}$ $\left(5.63 \mathrm{MJ} / \mathrm{m}^{2}-\mathrm{yr}\right.$ ) annually in consumption savings and $159 \mathrm{~kW}$ in demand savings (approximately $60 \%$ of the projected savings). Building D achieved BOMA BEST certification Level 2 with an overall building score of 73\% in March 2012 after having undergone this chilled water system retrofit.

The utility cost savings and maintenance cost savings associated with the chilled water plant retrofit would theoretically positively affect building asset value by decreasing operating costs and thus increasing net operating income. Additionally, the achievement of BOMA BESt Level 2 and overall improved sustainability at Building D would theoretically attract tenants and increase tenant retention, which leads to increased net operating income (NOI) through rent. Finally, Building D could charge more in direct rent as demand for space in a sustainable building would theoretically be higher. These theoretical links between Building D's retrofit and value (particularly NOI) are discussed qualitatively in this section.

Table 4-8 summarizes Building D's energy use intensity (EUI) annually from 2008 to 2011. Recall that Building D's retrofit occurred in 2010/2011.

Table 4-8 - Building D EUI

\begin{tabular}{ccc}
\hline Year & \multicolumn{2}{c}{ EUI } \\
\hline & $\left(\mathrm{MJ} / \mathrm{m}^{2}-\mathrm{yr}\right)$ & $\left(\mathrm{ekWh} / \mathrm{m}^{2}-\mathrm{yr}\right)$ \\
$\mathbf{2 0 0 8}$ & 2200 & 611.1 \\
$\mathbf{2 0 0 9}$ & 2162 & 600.6 \\
$\mathbf{2 0 1 0}$ & 2167 & 601.9 \\
$\mathbf{2 0 1 1}$ & 2134 & 592.7 \\
\hline
\end{tabular}

2008 to 2010 data were obtained from retrofit consultant reports [99]. 2011 data were obtained from BOMA [100]. Using 2010 retrofit consultant data as pre-retrofit data and 2011 BOMA data taken as post-retrofit data, the difference in EUI from 2010 to 2011 is equivalent to the energy savings measured by the retrofit consultant after the retrofit had been completed. Therefore, although the data in Table 4-8 were obtained from two different sources, they may be combined for analysis.

Overall, the retrofit would save approximately $0.94 \%$ of total building energy annually. These savings are quite small as this retrofit was a planned capital upgrade and not intended for the purpose of wholebuilding energy efficiency. 
Financial data for Building D was obtained through the Altus InSite financial database and also through the building operator [101, 106]. The Altus Insite database provided total additional rent (operating costs plus taxes) and occupancy data dating back to 2005; the building operator provided operation and maintenance (office standard O\&M) costs and occupancy data dating back to 2009. Unfortunately no direct asking rental rates were available; therefore conclusions regarding the relationship between increased energy efficiency and base rental rates could not be made. Altus InSite data were reported quarterly and building operator data were reported annually. To consolidate the results, annual averages of the Altus InSite data were taken. Raw data and detailed calculations are located in Appendix B. Table 4-9 summarizes the financial data obtained for Building D.

Table 4-9 - Building D Financial Data Summary

\begin{tabular}{|c|c|c|c|c|c|c|c|}
\hline \multirow{2}{*}{ Year } & \multirow{2}{*}{$\begin{array}{c}\text { Office } \\
\text { Standard } \\
\text { O\&M } \\
\left(\$ / \mathrm{m}^{2}\right)\end{array}$} & \multicolumn{2}{|c|}{ Occupancy Rate } & \multirow{2}{*}{$\begin{array}{c}\text { Direct } \\
\text { Asking } \\
\text { Rate } \\
\$ / \mathbf{m}^{2}\end{array}$} & \multirow{2}{*}{$\begin{array}{c}\text { Total } \\
\text { Additional } \\
\text { Rent }\left(\$ / \mathrm{m}^{2}\right)\end{array}$} & \multirow{2}{*}{$\begin{array}{c}\text { Total } \\
\text { Estimated } \\
\text { Direct Rent } \\
\left(\$ / \mathrm{m}^{2}\right)\end{array}$} & \multirow{2}{*}{$\begin{array}{c}\text { Total } \\
\text { Available } \\
\text { Area }\left(\mathrm{m}^{2}\right.\end{array}$} \\
\hline & & $\begin{array}{l}\text { Building } \\
\text { Operator }\end{array}$ & $\begin{array}{l}\text { Altus } \\
\text { InSite }\end{array}$ & & & & \\
\hline 2005 & nd & nd & $82.6 \%$ & $\$ 182.99$ & $\$ 194.50$ & $\$ 377.49$ & 6643.4 \\
\hline 2006 & nd & nd & $91.8 \%$ & $\$ 201.82$ & $\$ 192.78$ & $\$ 394.60$ & 3151.4 \\
\hline 2007 & nd & nd & $93.0 \%$ & $\$ 255.64$ & $\$ 197.52$ & $\$ 453.16$ & 2660.3 \\
\hline 2008 & nd & nd & $97.2 \%$ & $\$ 285.24$ & $\$ 208.93$ & $\$ 494.17$ & 1076.4 \\
\hline 2009 & $\$ 112.91$ & $98.9 \%$ & $97.1 \%$ & nd & $\$ 217.32$ & nd & 1119.8 \\
\hline 2010 & $\$ 118.40$ & $97.7 \%$ & $95.1 \%$ & nd & $\$ 226.28$ & nd & 1873.5 \\
\hline 2011 & $\$ 131.75$ & $97.2 \%$ & $92.3 \%$ & nd & $\$ 227.98$ & nd & 2964.8 \\
\hline 2012 & $\$ 124.97$ & $97.7 \%$ & $92.2 \%$ & nd & $\$ 229.59$ & nd & 3003.1 \\
\hline 2013 & $\$ 130.89$ & $99.7 \%$ & $92.5 \%$ & nd & $\$ 232.72$ & nd & 2887.3 \\
\hline 2014 & $\$ 129.70$ & $98.7 \%$ & $88.9 \%$ & nd & $\$ 234.65$ & nd & 4260.6 \\
\hline \multicolumn{8}{|c|}{ * nd indicates no data } \\
\hline
\end{tabular}

O\&M costs made up between approximately $52 \%$ and $58 \%$ of the total additional rent ( $55 \%$ on average) from 2009 and 2014 (Table 4-9). Since the proportion of total additional rent attributed to O\&M costs was relatively stable, it was reasonably assumed that these proportions would have held in from 2005 to 2008 as well. This assumption was made so that O\&M cost trends could be analyzed using total additional rent data from 2005 to 2014; O\&M costs would follow the same trends year to year as total additional rent. Therefore, total additional rent data provided by Altus Insite were analyzed to determine whether the 2010-2011 retrofit had an impact on O\&M costs and thus on NOI (Figure 4-12). 


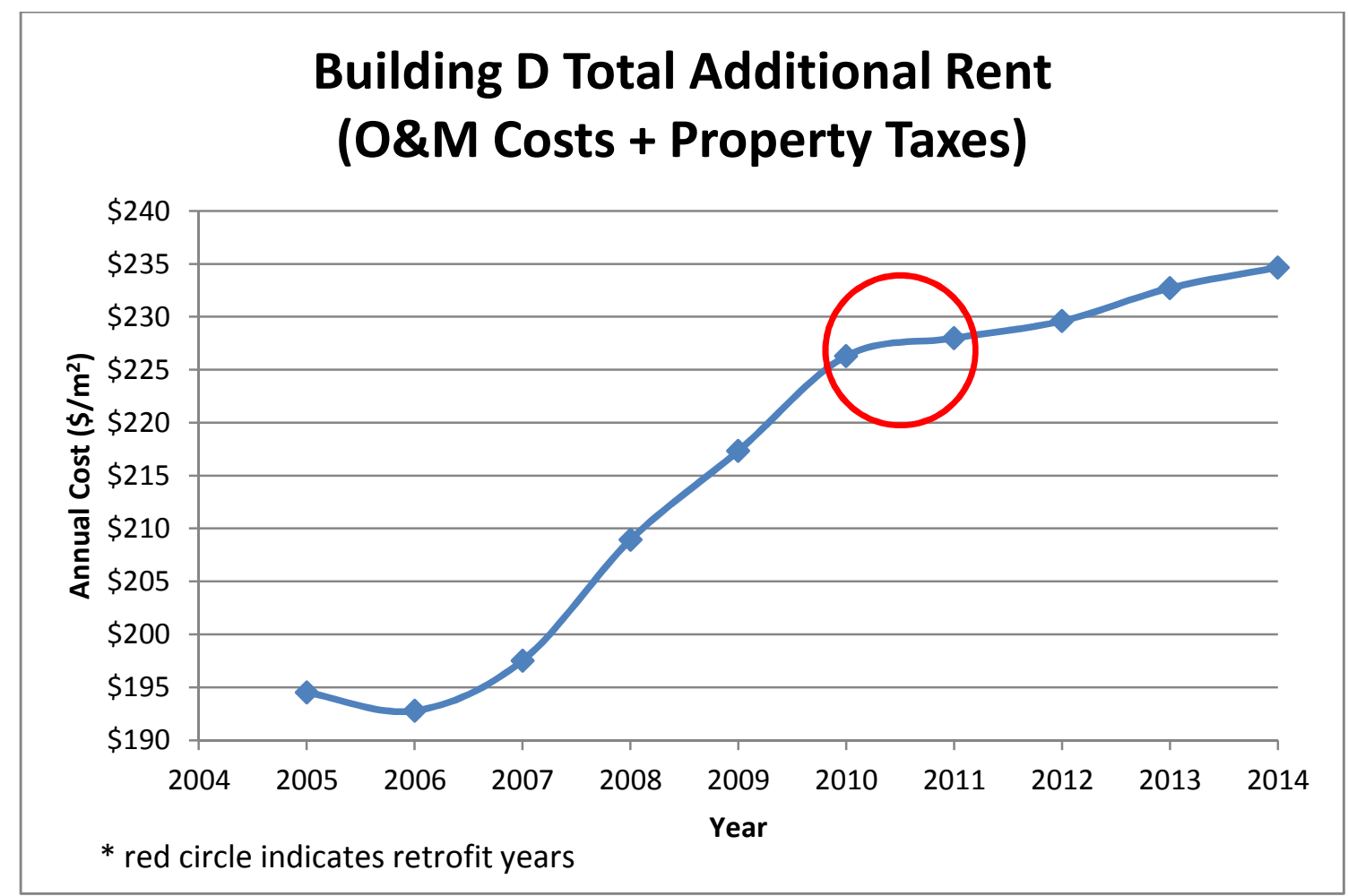

Figure 4-12 - Building D Total Additional Rent

Note the difference in cost scale compared to the other case studies. Before the retrofit, the total additional rent was climbing steeply. The average annual increase in total additional rent for the period between 2007 and 2010 was approximately $\$ 8.38 / \mathrm{m}^{2}$ and annual increase ranged between $\$ 4.74 / \mathrm{m}^{2}$ and $\$ 11.41 / \mathrm{m}^{2}$. After the retrofit, total additional rent still increased annually but by less. For the period between 2011 and 2014 (inclusive), total additional rent increased by an average of $\$ 2.09 / \mathrm{m}^{2}$ annually with total additional rent values ranging between $\$ 1.61 / \mathrm{m}^{2}$ and $\$ 3.12 / \mathrm{m}^{2}$. Therefore, Building D's retrofit slowed the rate of increase of total additional rent. Assuming O\&M costs followed a similar trend (as previously determined valid), Building D's retrofit would have slowed the rate of increase of O\&M costs and consequently slowed the rate of increase of net costs annually. Although these costs are still increasing and would therefore decrease NOI and thus decrease Building D's value if all other income capitalization approach variables remained constant, slower cost increases would slow the resultant decreases in value. In actuality, other factors would be changed to make up for these cost increases like increases in direct asking rates. Additionally, other factors would change due to external forces, such as property tax rates. 
Another consideration is the effect of total additional rent increases on tenants. Total additional rent is added to base rent to cover building operations, maintenance, and property tax costs. Slowing the rate of increase of total additional rent allows the building owner to maintain more competitive total rental rates despite increasing energy prices.

Figure 4-13 compares total additional rent increases to Toronto Hydro electricity prices increases. The percentage indicates an increase for a given year when compared to the previous year. Building D has an interval electricity meter and uses electricity at the IESO hourly Ontario energy price - a price that changes hourly based on changes in demand on the grid and availability of electrical supply [85].

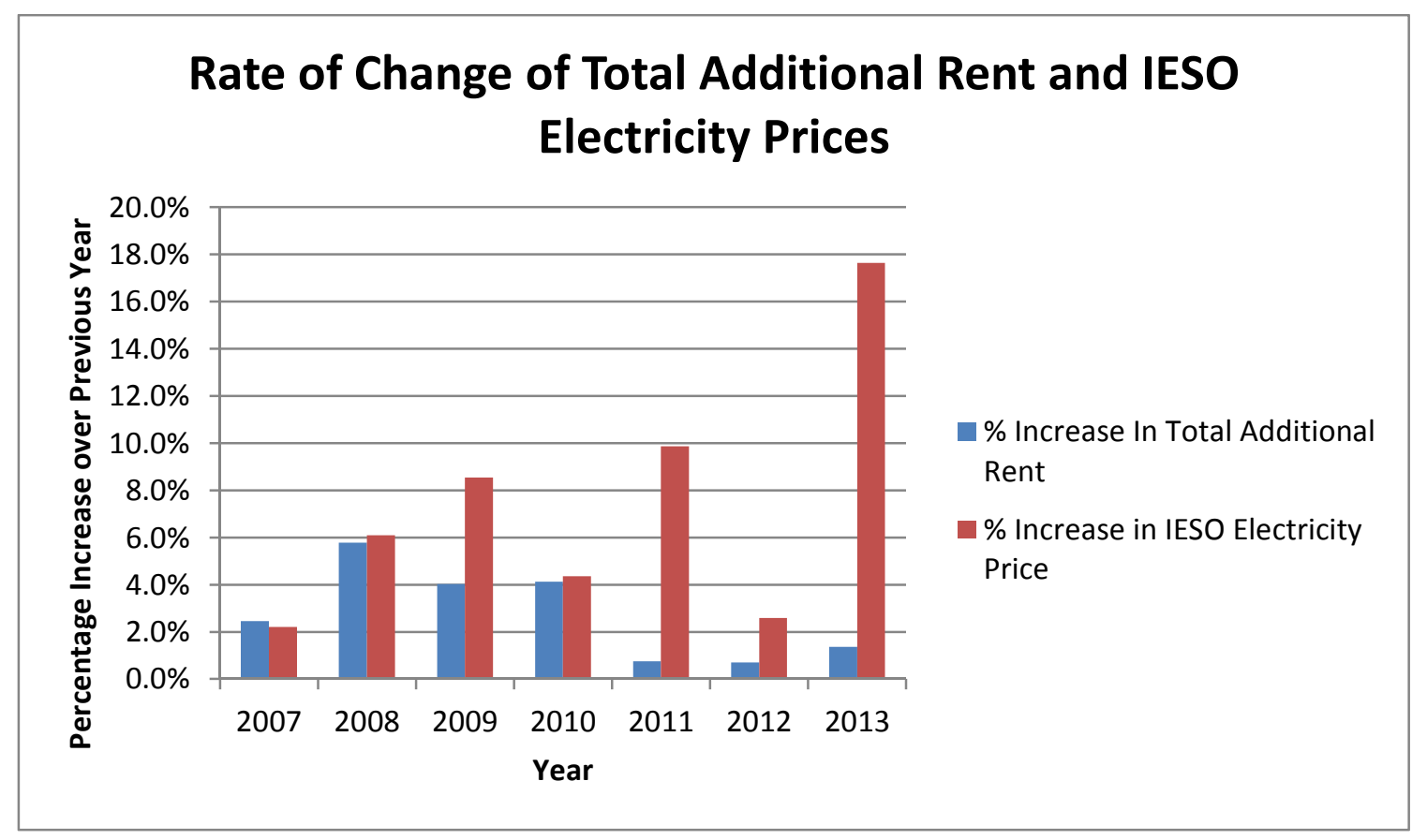

Figure 4-13 - Annual Total Additional Rent and IESO Electricity Price Increases [101, 85]

In the years after the retrofit (2011 onward), increases in total additional rent are significantly smaller than the increases in IESO electricity prices. In 2013 , the IESO electricity price was $17.6 \%$ higher than in 2012 , but the total additional rent was only $1.4 \%$ higher [85]. This brings to light the financial importance of lessening dependence on grid electricity prices through energy conservation.

Based on post-retrofit BOMA data, natural gas made up approximately $10.8 \%$ of total utility costs in the year after the retrofit [100]. Using the savings estimate provided by the retrofit consultant, it is estimated that immediately before the retrofit natural gas made up approximately $10.0 \%$ of total utility 
costs [107]. It is therefore evident that Building D's utility costs are far more sensitive to changes in electricity prices than natural gas prices. Comparisons of natural gas price increases and total additional rent have not been made since retrofit targeted electricity savings only.

Occupancy data were provided by two different sources for Building D - Altus Insite and the building operator. Differences of up to $10 \%$ were observed between occupancy rates provided by the Altus InSite database and the building operator; Figure 4-14 shows occupancy data provided by both sources.

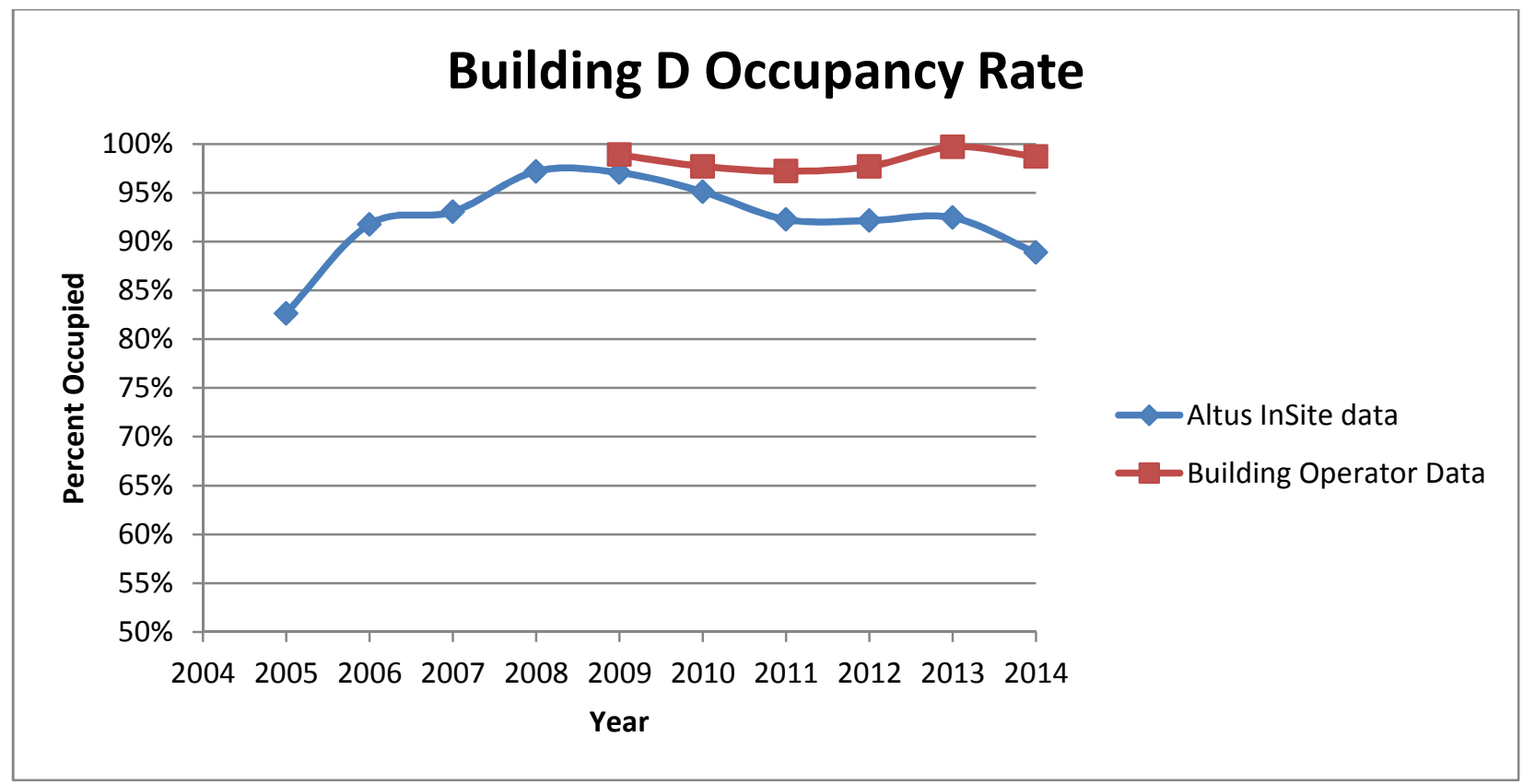

Figure 4-14 - Building D Occupancy Rates

There is a marked difference in the data from each source, but both sources follow a similar pattern: a decline in occupancy between 2009 and 2011 followed by an increase between 2011 and 2013 and then another decrease in 2014. The occupancy rate increase between 2011 and 2013 was $0.2 \%$ according to Altus InSite data and $2.5 \%$ according to building operator data. Although this slight increase coincides with the completion of the chilled water plant retrofit and resulting achievement of BOMA BESt Level 2, the 2013 to 2014 occupancy rate decrease of 3.6\% according to Altus Insite data or $1.0 \%$ according to building operator data negates any conclusions on positive or negative effect of the retrofit on Building D's occupancy rates. Overall, both sources reported lower occupancy rates in 2013 than in 2009 (the year before the retrofit). Toronto's downtown commercial building market experienced an overall 
increase in occupancy during this time. It does not appear that Building D's occupancy rate was improved by the retrofit.

Total estimated direct rental rates for Building D were missing from 2009 to 2014 inclusive. An assumption regarding the relationship between effective total estimated direct rent and effective total additional rent could not be made for this case because of this lack of data.

Total additional rent rates were multiplied by their corresponding annual occupancy rate to yield effective total additional rent; about $55 \%$ of which would be effective O\&M costs (Figure 4-15). Note the difference in cost scale compared to the other case studies.

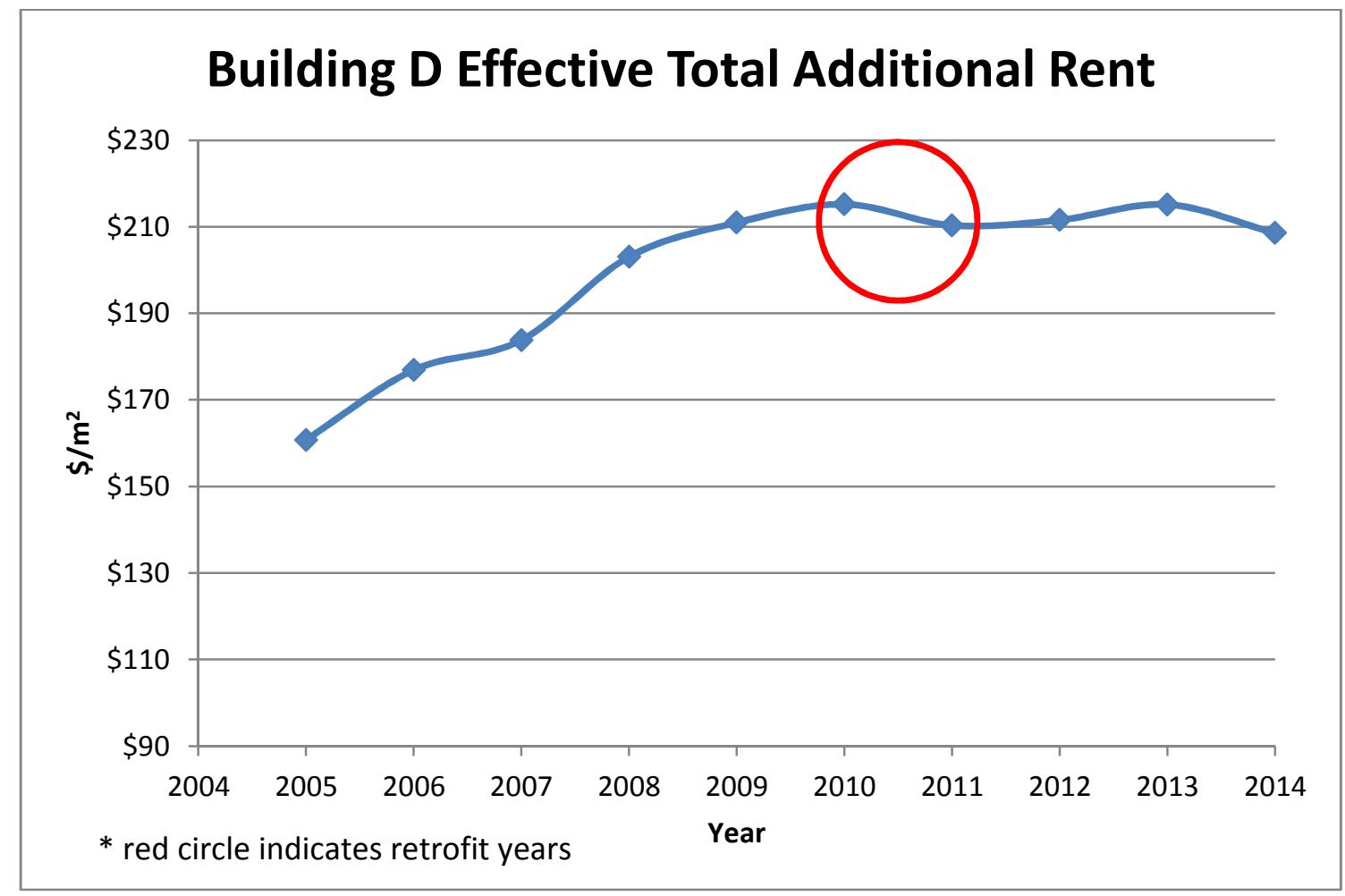

Figure 4-15 - Building D Effective Total Additional Rent

Building D's effective total additional rent was increasing pre-retrofit and stabilized post-retrofit. Postretrofit, rising O\&M costs increased total additional rent and the building owner would charge the tenants to cover these costs. However, decreased occupancy rates stabilized the effective total additional rent portion of the owner's rental revenue. The combination of this revenue stabilization with increasing annual O\&M costs may have had a negative NOI effect. However, without knowing direct asking rates for the post-retrofit analysis period, no such conclusion can be definitively made. 


\subsubsection{Building D Conclusions}

Building D's chilled water plant retrofit saves $0.94 \%$ (775 GJ/year or $20.25 \mathrm{MJ} / \mathrm{m}^{2}$-year) of the building's total annual energy compared to pre-retrofit conditions. It was also projected to save $\$ 124,000$ annually; although these cost savings were not verified post-retrofit, they would equate to approximately $6.6 \%$ of pre-retrofit energy costs.

It was observed that $\mathrm{O} \& \mathrm{M}$ costs increased at a slower rate post-retrofit than pre-retrofit, reducing negative NOI effects. No conclusions were made for total estimated direct rent based on total additional rent trend analysis. Effective total additional rent stabilized post-retrofit (after having increased pre-retrofit) as a result of decreased occupancy rates, which could have negatively affected $\mathrm{NOI}$ and thus building value. However, no definitive conclusion could be made because of missing direct asking rates. 


\section{Discussion}

\subsection{Energy Results}

Table 5-1 summarizes the energy savings and green certification results of the retrofit cases analyzed in the previous section.

Table 5-1 - Energy Data Summary

\begin{tabular}{|c|c|c|c|c|c|c|}
\hline Building & $\begin{array}{c}\text { Pre-retrofit } \\
\text { EUI } \\
\text { (GJ/m² GFA) }\end{array}$ & $\begin{array}{c}\text { Retrofit } \\
\text { Energy } \\
\text { Savings } \\
\text { (GJ } / \mathrm{m}^{2} \text { GFA) }\end{array}$ & $\begin{array}{c}\text { Retrofit } \\
\text { Energy } \\
\text { Savings } \\
\text { (\%) }\end{array}$ & $\begin{array}{c}\text { Post- } \\
\text { retrofit EUI } \\
\left(\mathrm{GJ} / \mathrm{m}^{2} \mathrm{GFA}\right)\end{array}$ & $\begin{array}{l}\text { Post-retrofit } \\
\text { Certifications } \\
\text { - LEED EB:OM }\end{array}$ & $\begin{array}{l}\text { Post-retrofit } \\
\text { Certifications } \\
\text { - BOMA BESt }\end{array}$ \\
\hline A & 1.94 & 0.27 & $13.8 \%$ & 1.68 & Gold (2012) & Level 3 (2010) \\
\hline B & 1.24 & 0.22 & $18.0 \%$ & 1.01 & Gold (2011) & Level 3 (2012) \\
\hline C & 1.60 & 0.29 & $18.0 \%$ & 1.31 & Gold (2011) & Level 3 (2012) \\
\hline D & 2.15 & 0.02 & $0.9 \%$ & 2.13 & - & Level 2 (2012) \\
\hline
\end{tabular}

Buildings $A, B$, and $C$ underwent extensive retrofits while Building $D$ underwent a retrofit of its chilled water plant only as part of the building management's capital upgrade plan. Energy savings at Building D were significantly lower and its EUI significantly higher than the other buildings both before and after having been retrofit.

Each building's pre- and post-retrofit EUls have been benchmarked against NRCan's 2009 Survey of Commercial and Institutional Energy Use, which determined that non-medical office buildings in Canada had average annual EUI of $1.20 \mathrm{GJ} / \mathrm{m}^{2}\left(333 \mathrm{ekWh} / \mathrm{m}^{2}\right)$ [5]. Figure 5-1 shows the benchmarking results note that the horizontal axis crosses the vertical axis at $1.20 \mathrm{GJ} / \mathrm{m}^{2}$ to show which buildings were above and below the 2009 NRCan average EUI for office buildings. Recall that energy use data is not weathernormalized and therefore may implicitly include the effects of weather. 


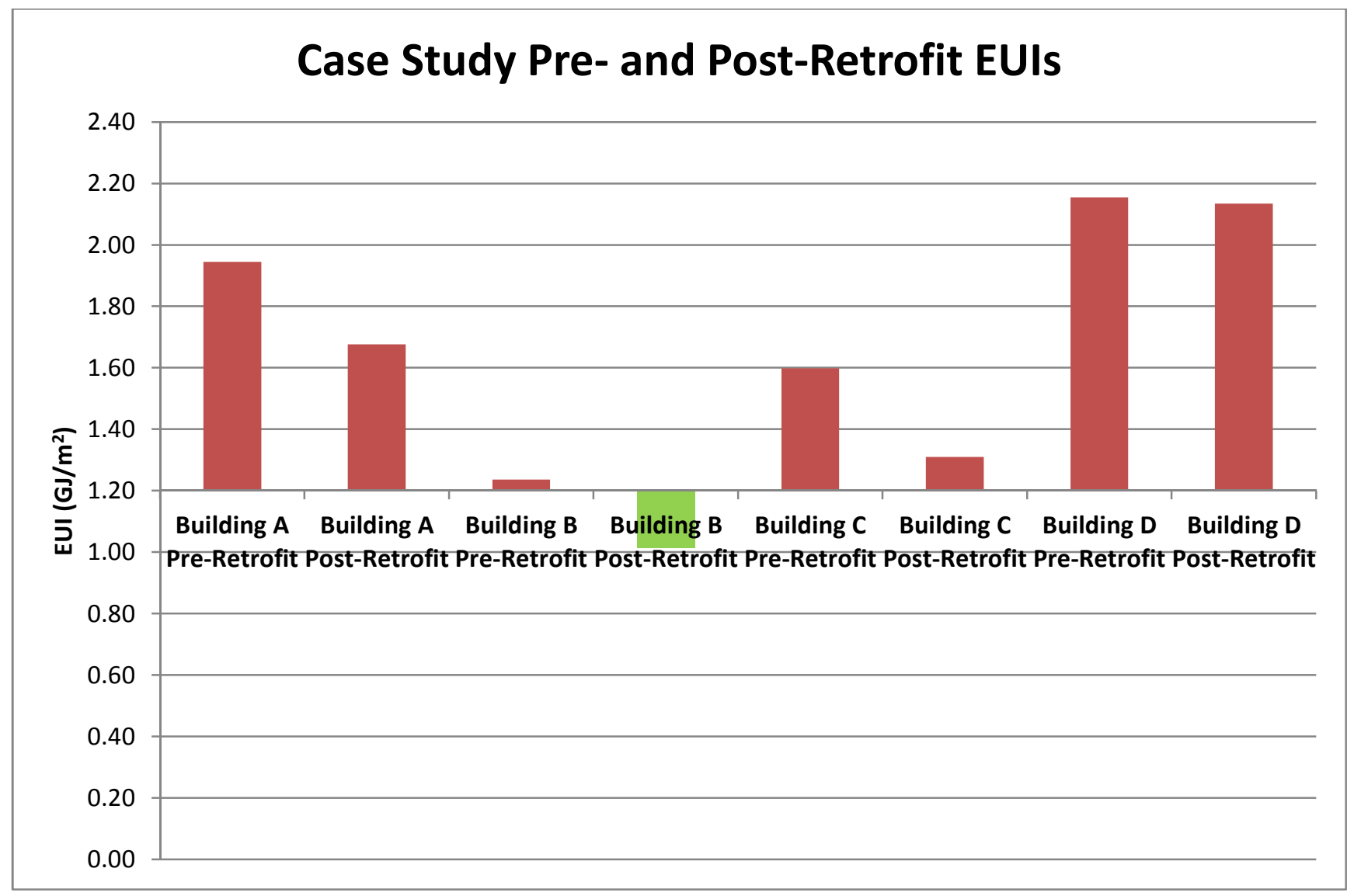

Figure 5-1 - Case Study Pre- and Post-Retrofit EUls

Only Building B's post-retrofit EUI was less than the 2009 NRCan average. Building C also approached the average post-retrofit.

\subsection{Financial Results}

All financial data obtained for these case studies related to rental rates, O\&M costs, and occupancy rates. Trends for all buildings are discussed in this section.

\subsubsection{Occupancy Rate Results}

Building occupancy rate was observed for all buildings from 2005 to 2014; Figure 5-2 displays the results as well as the Toronto market trend. 


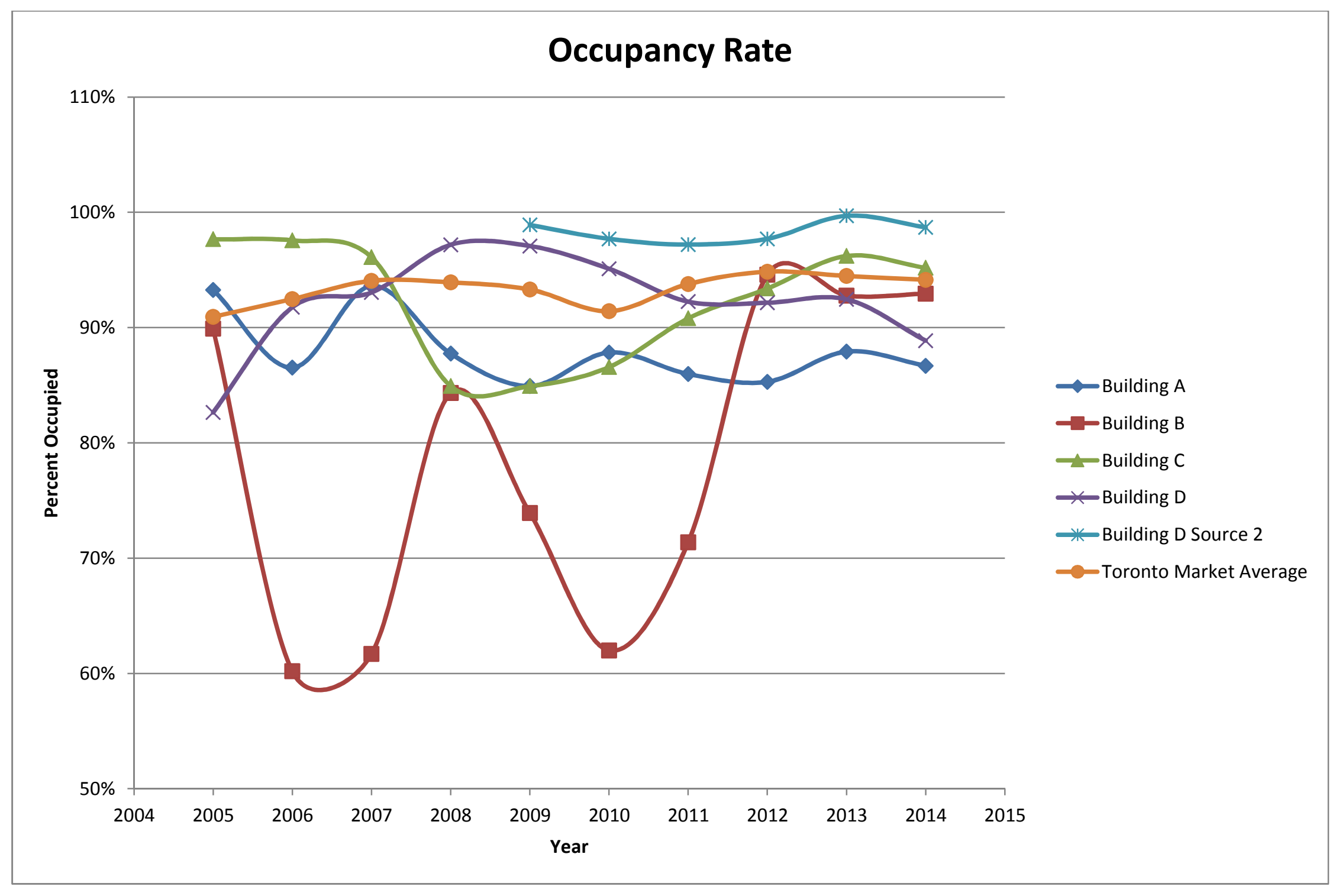

Figure 5-2 -Occupancy Rate Results

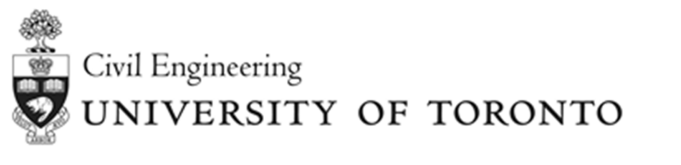

Value Impacts of Energy Efficiency Retrofits on

Commercial Office Buildings in Toronto, Canada | 83 
Recall that Building A was retrofitted in 2009 and Building B, Building C, and Building D were retrofitted in 2010-2011. The downtown Toronto market trend was an increase of about 3\%-4\% between 2005 and 2014. 2010 to 2014 occupancy rates were typically equal to or greater than 2005 to 2009 occupancy rates for the Toronto downtown market.

Building B's occupancy rate exhibited the most volatility over the analysis period, fluctuating between about $60 \%$ and $95 \%$. During the building's retrofit (2010-2011), occupancy was quite low (approximately 62\% to 72\%). Occupancy increased following the retrofit and then stabilized from 2012 to 2014 around 93\%, a higher occupancy rate than pre-retrofit. Post-retrofit occupancy was not only higher but also less volatile. Between 2005 and 2014, Building B's occupancy rate increased at a much higher rate than the downtown Toronto office market average and ended this period at approximately the same occupancy rate as the market average. Building B's significant occupancy rate increase can be attributed to the building's retrofit.

Building A's occupancy rate was also volatile, oscillating between approximately $85 \%$ and $93.5 \%$ preretrofit and between approximately $85 \%$ and $88 \%$ post-retrofit. Pre-retrofit oscillation amplitude is three times as large as post-retrofit oscillation. Building A had a more consistent occupancy rate but also a lower occupancy rate on average after having been retrofitted. During Building A's post retrofit period of lower occupancy, the downtown Toronto office market overall occupancy rate increased. Thus, it does not appear as though the retrofit impacted occupancy rates in this case.

Building C's occupancy rate was high (nearing 98\%) until it plummeted to approximately $85 \%$ in $2007 / 2008$ as the result of one major tenant moving out. After having been retrofitted, Building C's occupancy rates climbed at a rate greater than that of the overall downtown Toronto market to reach a rate approximately equal that of the overall market in 2014. Retrofitting increased Building C's occupancy rate through attraction of tenants to the improved facility and likely resulted in occupancy rate increases that exceeded those in the marketplace.

Building D's occupancy rate trend shows a decline in occupancy between 2009 and 2011 followed by an increase between 2011 and 2013 and then another decrease in 2014. Although the slight increase coincides with the completion of the retrofit, the 2013 to 2014 occupancy rate decrease negates any conclusions on positive or negative effect of the retrofit on Building D's occupancy rates. Overall, both sources reported lower occupancy rates in 2013 than in 2009 (the year before the retrofit). Toronto's 
downtown commercial building market experienced an overall increase in occupancy during this time. Therefore, it does not appear that Building D's occupancy rate was improved by the retrofit.

Overall, occupancy data trends from these four case studies reveal that post-retrofit occupancy rates are less volatile than pre-retrofit rates. For two buildings, occupancy rates increased post-retrofit. Two buildings had lower occupancy rates post-retrofit than pre-retrofit. It is therefore concluded that retrofitting buildings can increase occupancy rate but do not necessarily do so. Other factors that affect occupancy rate variations (such as lease term end timing) can outweigh the effects of an energy retrofit.

The effects of occupancy rate on building owner rental revenue will be discussed in Section 5.2.3.

\subsubsection{Total Additional Rent Results}

Total additional rent refers to operating and maintenance costs plus taxes. For Building B and Building C it was determined that operating costs would follow the same trend as total additional rent; for Building D it was determined that O\&M costs would follow the same trends as total additional rent. No such conclusion could be made for Building A. Figure 5-3 shows the total additional rent trends for all four buildings. Figure 5-4 shows the same trends but with Building $D$ removed for a better look at Building $A$, Building $B$, and building $C$ trends. 


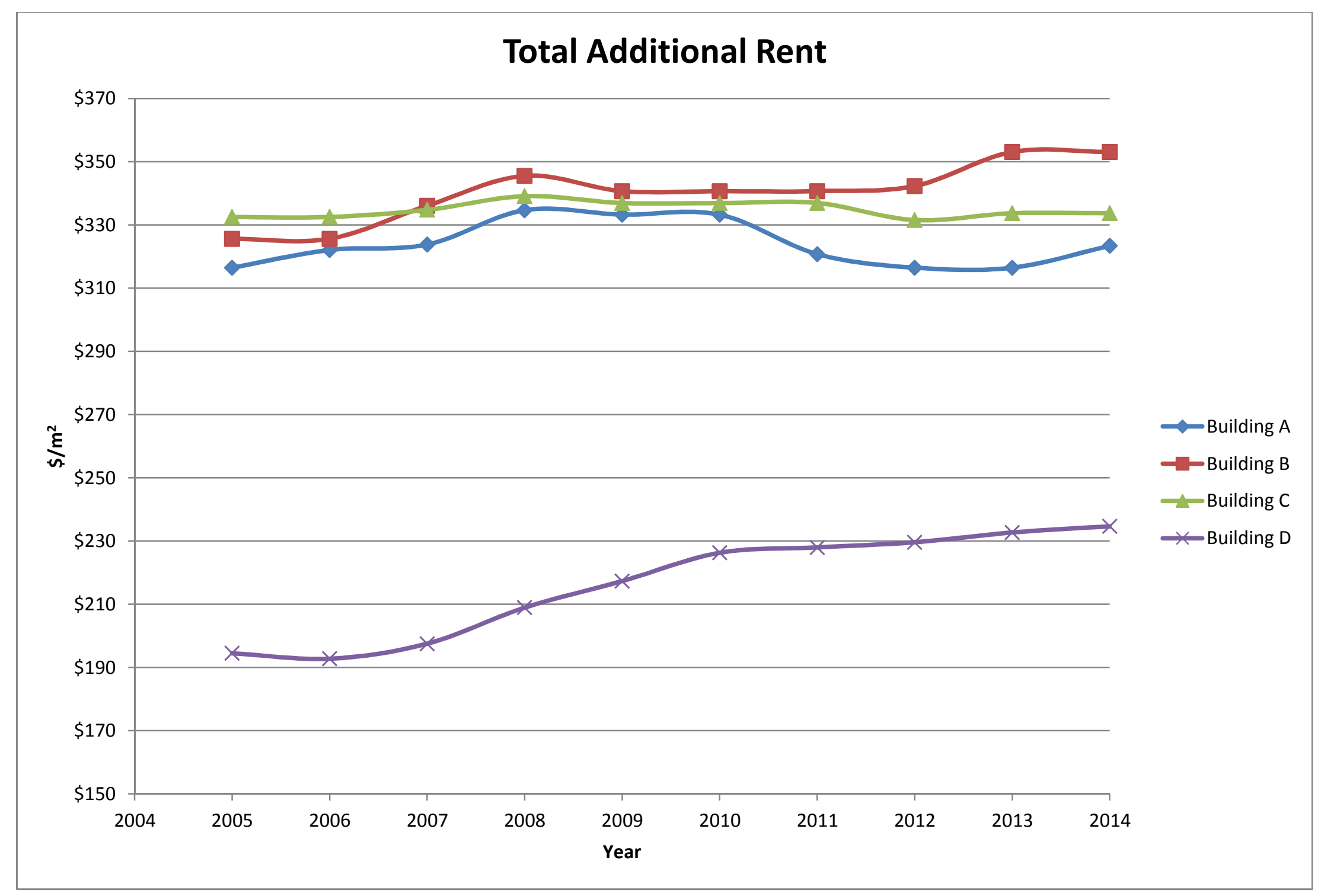

Figure 5-3 -Total Additional Rent Results 


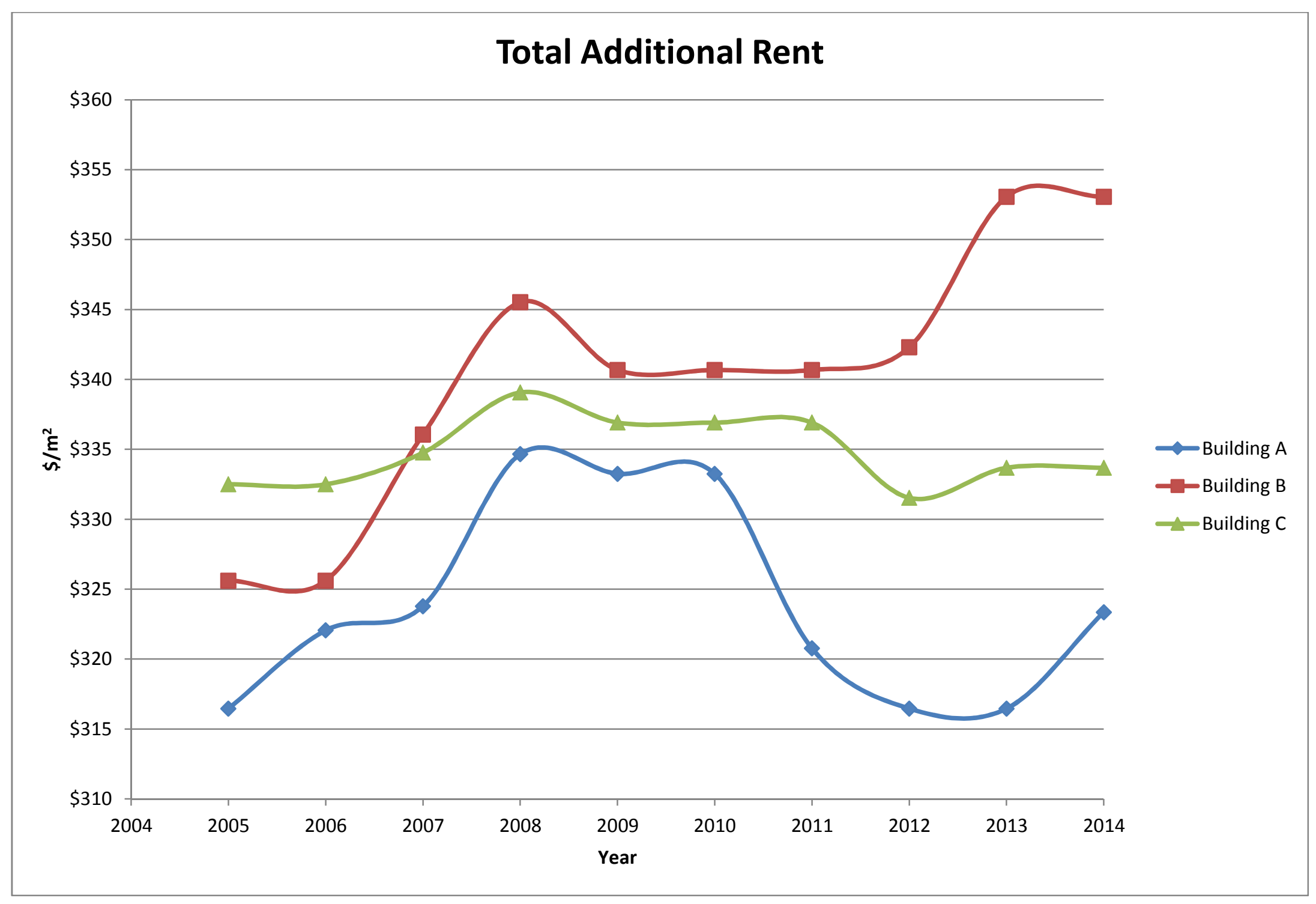

Figure 5-4 -Total Additional Rent Results for Buildings A, B, and C Only 
Refer back to Figure 4-2 for downtown Toronto Class A office building market average rents for the period between 2010 and 2014. Market average total additional rent was constant in 2010 and 2011, dropped by about $2 \%$ in 2012 and remained constant in 2013, then rose by about $2 \%$ in 2014 .

Building A's total additional rent was rising pre-retrofit, then dropped by $5 \%\left(\$ 16.79 / \mathrm{m}^{2}\right)$ between 2010 and 2012 as a result of energy savings achieved through the retrofit. This decrease is $3 \%$ greater than the market average decrease in total additional rent for the same time period. In 2013, total additional rent remained constant as did the market's average. Building $A$ 's total additional rent rose by $2.2 \%$ in 2014 (market average rose by 2\%), an event which coincided with a significant increase in energy prices. However, total additional rent remains lower than it was in 2010. Overall, Building A's retrofit resulted in a decrease in total additional rent immediately after the retrofit and then, four years after the retrofit, total additional rent began to closely follow market average trends. No qualitative relationship was determined between Building A's total additional rent and its O\&M costs; however, total additional rent is related to O\&M costs which are in turn related to utility spending.

Building B's total additional rent (and thus operating costs) was steadily rising before 2008. Total additional rent would then drop slightly and plateau around $\$ 341 / \mathrm{m}^{2}$ for the retrofit period and 2012 ( $40 \%$ to $44 \%$ higher than the market average). Operating costs would follow the same trend, remaining relatively stable between 2009 and 2012, even though electricity prices rose by 4.4\% in 2010, 9.9\% in 2011 , and $2.6 \%$ in 2012 . In 2013, total additional rent rose again, coinciding with $17.6 \%$ increase in electricity price. It is possible that the retrofit helped in keeping total additional rent constant from 2009 to 2012 through decreased utility spending. However, no definite conclusion can be made from this trend.

Building C's total additional rent (and thus operating costs) rose steadily between 2005 and 2008, although not by as much as for Building B. Total additional rent dropped slightly in 2009 and plateau around $\$ 337 / \mathrm{m}^{2}$ for the retrofit period (39\% higher than the market average). After the 2010-2011 retrofit, total additional rent dropped by $1.6 \%$ to below 2005 levels as a result of utility consumption reductions; the market average also dropped by about $2 \%$ at this time. Total additional rent increased again in 2013 but remains below 2009 pre-retrofit levels. The 2013 increase can be explained by increases in energy prices during that year.

Civil Engineering UNIVERSITY OF TORONTO
Value Impacts of Energy Efficiency Retrofits on Commercial Office Buildings in Toronto, Canada | 88 
Building D's total additional rent (and thus O\&M costs) was climbing steeply before the building's 20102011 retrofit. The average annual increase in total additional rent between 2008 and 2010 (inclusive) was approximately $\$ 8.38 / \mathrm{m}^{2}$ (4.0\% per year). After the retrofit, total additional rent still increased annually but by less. Market average total additional rent decreased by $2 \%$ in 2012 and increased by $2 \%$ in 2014; during this period, Building D's total additional rent increased steadily. For the period between 2011 and 2014 (inclusive), Building D's total additional rent increased by an average of $\$ 2.09 / \mathrm{m}^{2}$ (2\%) annually.

Building D's retrofit slowed the rate of increase of total additional rent. O\&M costs followed a similar trend; Building D's retrofit slowed the rate of increase of O\&M costs and consequently slowed the rate of increase of net costs annually. Although these costs are still increasing and would therefore decrease $\mathrm{NOI}$ and thus decrease value if all other variables remained constant, slower cost increase would slow the resultant decreases in value.

Overall, total additional rent typically dropped and/or stabilized due to retrofitting (except for Building $D$, for which the rate of increase of total additional rent decreased). Decreases in total additional rent were a result of utility cost savings through retrofit implementation. This analysis shows that retrofitting decreases operational costs and therefore decreases costs overall. If all other factors remained constant, this effect would increase NOI.

\subsubsection{Effective Total Additional Rent Results}

The building owner's rental revenue is determined by a combination of rental rate and occupancy rate known as effective rent. Effective rent refers to how much of asking rent a property is actually converting to revenue. For Building $A$, Building $B$, and Building $C$ it was determined that effective total estimated direct rent (total rental revenue) would follow the same trends as effective total additional rent. This was not true for Building D, but Building D's effective total additional rent trends were analyzed anyway to observe the effect of occupancy rates on how much of total additional rent was being converted into revenue over the analysis period. Figure 5-5 shows the effective total additional rent trends for all four buildings.

Civil Engineering UNIVERSITY OF TORONTO
Value Impacts of Energy Efficiency Retrofits on Commercial Office Buildings in Toronto, Canada | 89 


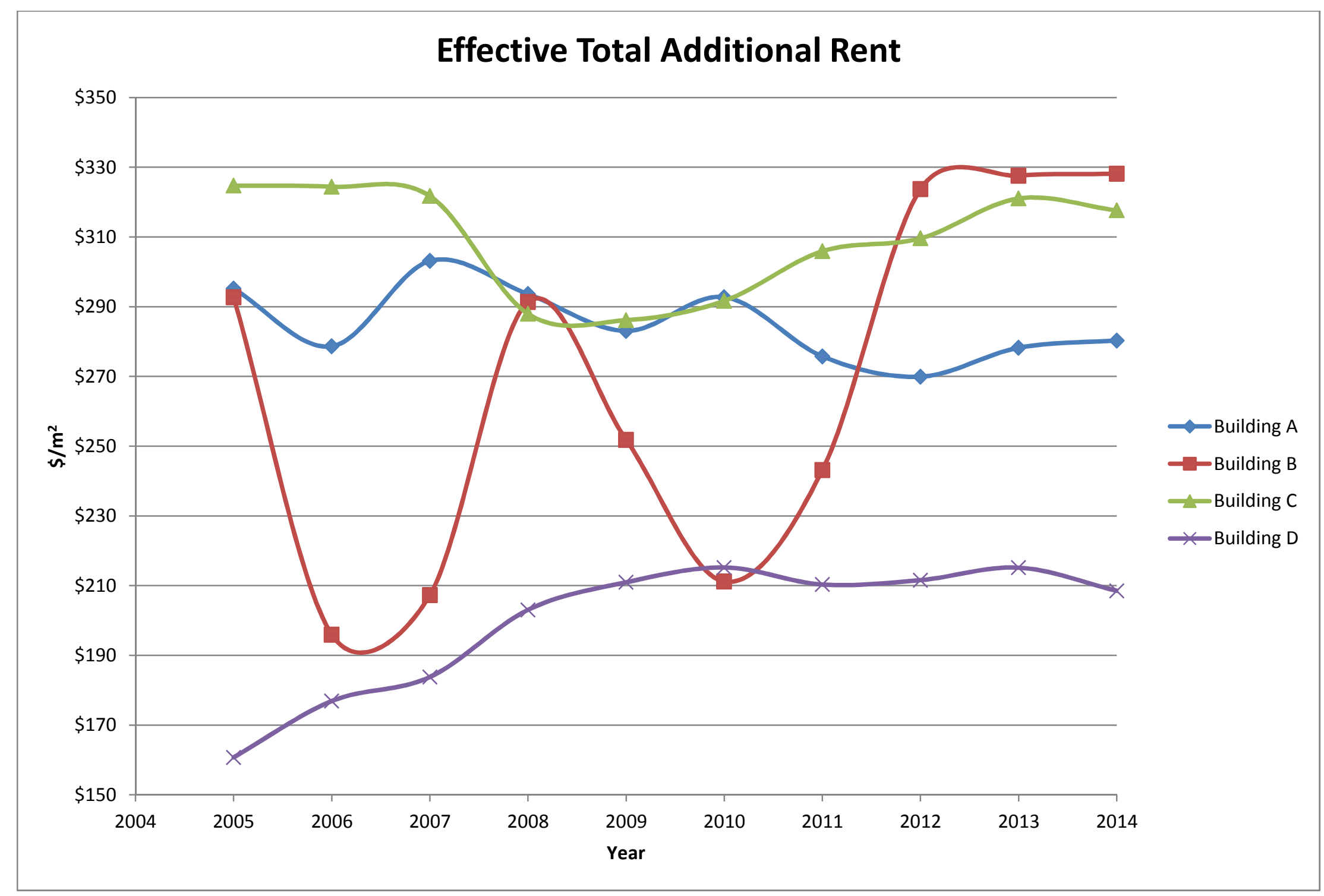

Figure 5-5 -Effective Total Additional Rent Results 
Building A's effective total additional rent was heavily influenced by occupancy rate and appears to follow a similar trend. Post-retrofit effective total additional rent is lower than pre-retrofit conditions even though O\&M costs are lower because of increased vacancy rates. Total estimated direct rent (overall rental revenue) would follow a similar pattern. This translates directly to a decrease in NOI despite energy cost savings achieved by retrofitting the building.

Building B's effective total additional rent was also heavily influenced by occupancy rate and appears to follow a similar trend. Building B's effective total additional rental rate ranged between approximately $\$ 196 / \mathrm{m}^{2}$ and $\$ 293 / \mathrm{m}^{2}$ between 2005 and 2011. Upon retrofit completion, effective total additional rent rose and then plateaued at approximately $\$ 328 / \mathrm{m}^{2}$ in 2013 and 2014 - an increase of about 35\% over 2011 pre-retrofit effective total additional rent. Post-retrofit effective total additional rent is not only higher but also less volatile (similar to occupancy rate patterns). When post-retrofit conditions were compared to peak pre-retrofit conditions (2008 data), the calculated increase in effective total additional rent was approximately $12.5 \%$. Since effective total estimated direct rent follows the same trends as effective total additional rent, effective total estimated direct rent (i.e. rental revenue incurred by the owner) increased by approximately $12.5 \%$ to $35 \%$ post-retrofit depending on which pre-retrofit year is chosen as a baseline for comparison. This directly translates into a higher NOI.

Building C's effective total additional rent was heavily influenced by occupancy rate and appears to follow a similar trend. Building C's effective total additional rent was stable from 2005 to 2007 until it plummeted 2008, coinciding with one major tenant moving out of the building [74]. Post-retrofit, effective total additional rent climbed steadily; 2013 effective total additional rent was approximately 5\% higher than 2011 pre-retrofit effective total additional rent. However, this was still 1\% lower than the 2005 effective total additional rent. Still, analysis of this pattern reveals that retrofitting positively impacted effective rental revenue, thereby positively affecting NOI and increasing building value.

An assumption regarding the relationship between effective total estimated direct rent and effective total additional rent could not be made for Building D because of a lack of data. Building D's effective total additional rent was increasing pre-retrofit and stabilized post-retrofit. The combination of this revenue stabilization with increasing annual O\&M costs may have had a negative NOI effect. However, without knowing direct asking rates for the post-retrofit analysis period, no such conclusion could be definitively made.

Civil Engineering UNIVERSITY OF TORONTO
Value Impacts of Energy Efficiency Retrofits on Commercial Office Buildings in Toronto, Canada | 91 
Overall, the most significant conclusion made from the analysis of effective total additional rent is that occupancy rates heavily influence rental revenue and thus NOI. Two buildings experienced post-retrofit increases in rental revenue and thus NOI, one experienced negative NOI effects as a result of lowered occupancy rates, and one was inconclusive due to missing data.

\subsubsection{Results Comparison to Related Empirical Studies}

The goal of this thesis was to determine if and how energy efficiency improvements and asset value are related in Canadian commercial office buildings. Other, large-scale U.S. studies indicated that sustainable buildings (as determined by LEED or ENERGY STAR certification achievement), compared rental and sales data to observe this relationship. No sales cases were examined in this thesis, but rental results are compared to these U.S. studies to determine if similar trends are occurring in the Canadian building market. Rental data results from the U.S. studies were:

- Green building rental premia were generally found to be between $2.8 \%$ and $17.3 \%$ above noncertified buildings, and one study observed a $50 \%$ premium;

- Effective rental premia for green buildings ranged between $7 \%$ and $8 \%$ above non-certified buildings.

These studies did not comment on the levels of energy use in green buildings versus non-green buildings. Of the eight U.S. studies reviewed, all analyzed rental data but only three analyzed effective rent and all three had common authors. Over the course of this study, the author observed the importance of factoring occupancy rates into the analysis of rental data in order to determine an effect on NOI; building rental revenue (effective total estimated direct rent) depended heavily on occupancy rates for the case studies contained herein.

Analyzing rental data without occupancy rates does not capture the full effect of increased rent on NOI because it does not capture how much of the rental rate is actually converted into income incurred by the building owner. For example, having a lower rental rate could still result in higher effective rental rate (building rental revenue) if occupancy rates were high enough; in fact, keeping lower and thus more competitive-looking rental rates is a strategy often employed by building owners to attract tenants to fill their buildings. Conversely, one case study (Building A) exhibited a decrease in rental revenue despite achieving energy savings through retrofitting because occupancy simultaneously decreased.

Civil Engineering UNIVERSITY OF TORONTO
Value Impacts of Energy Efficiency Retrofits on Commercial Office Buildings in Toronto, Canada | 92 
Two cases studied in this thesis yielded quantitative results indicating increases in rental revenue (effective total estimated direct rent) after having been retrofitted; one case exhibited an increase between $12.5 \%$ and $35 \%$ and the other exhibited an increase of $5 \%$. These values are somewhat comparable to the results of previous U.S. studies, although $35 \%$ is much higher. The quantitative effective rent results of this study were determined using case studies where major retrofits were undertaken for significant energy savings and for the achievement of green building certifications.

Although this data set was small in this study, the process outlined herein can be replicated for any other retrofitted building. Perhaps as the commercial office sector becomes more receptive to the sharing of financial data for this kind of analysis and more aware of the importance of studying all financial implications of energy retrofits, a larger sample of buildings can be analyzed to arrive at statistically significant conclusions on the relationship between building energy efficiency and asset value.

\subsubsection{The Relationship between Effective Rent and Building Value}

This section discusses how the observed effects of retrofitting on effective rent are incorporated directly into building value.

Rental rate and occupancy data were analyzed for all four case studies in this thesis. These two factors heavily influence building value. In simplified form, the income capitalization approach adopted for this study takes the following form $[27,65]$ :

$$
\text { Value }=\frac{\text { Net Operating Income }}{\text { Capitalization Rate }}
$$

The increase in the building's value over a given period of time would be calculated as follows:

$$
\% \text { value increase }=\frac{\text { post retrofit value }- \text { pre retrofit value }}{\text { pre retrofit value }}
$$

A negative percentage value increase would indicate a decrease in value.

The capitalization rate is determined by the appraiser and accounts for risks $[27,65]$. Capitalization rate data could not be obtained for these case studies. The calculation of capitalization rate should be performed by appraisal professionals. A 2014 CBRE Group report containing major Canadian market

Civil Engineering UNIVERSITY OF TORONTO
Value Impacts of Energy Efficiency Retrofits on Commercial Office Buildings in Toronto, Canada | 93 
statistics reported that Toronto downtown Class A office building capitalization rates were stable and between $4.75 \%$ and $5.75 \%$ from 2012 to 2014 , inclusive [108].

$\mathrm{NOI}$ is calculated by determining the gross revenues of the property and subtracting the operating expenses [65].

$$
\mathrm{NOI}=\text { income }- \text { expenses }
$$

For the sake of this discussion it is assumed that total income is equal to rental income alone and that tax benefits/credits are included in the net cost of taxes. Rental income is represented by the effective total estimated direct rent. Assumptions on the relationship between effective total estimated direct rent and the data obtained for effective total additional rent were made on a case-by-case basis. For Building A, Building B, and Building C, effective total additional rent made up approximately half of the effective total estimated direct rent. It was also observed that this approximation held for the downtown Toronto office building market from 2010 to 2014 [73]. No assumption of this kind was made for Building D.

Expenses include O\&M costs, taxes, insurance, advertising, and other fees [109]. O\&M costs plus taxes are represented by total additional rent (note that this is not the same as effective total additional rent). Let other expenses be represented by "OEXP". Then, NOI = income - expenses becomes:

$$
\begin{aligned}
& \text { NOI }=\text { effective total estimated diret rent }-(\text { total additional rent }+ \text { OEXP }) \\
& \text { NOI } \cong 2 \times(\text { effective total additional rent })-(\text { total additional rent }+ \text { OEXP })
\end{aligned}
$$

Recall that effective total additional rent $=$ total additional rent $\times$ occupancy rate.

$$
\begin{gathered}
\text { NOI } \cong 2 \times(\text { occupancy rate }) \times(\text { total additional rent })-(\text { total additional rent }+ \text { OEXP }) \\
\text { NOI } \cong 2 \times(\text { occupancy rate }) \times(\text { total additional rent })-\text { total additional rent }- \text { OEXP } \\
\text { NOI } \cong \text { total additional rent } \times[2 \times(\text { occupancy rate })-1]-\text { OEXP }
\end{gathered}
$$

Therefore,

$$
\text { Value } \cong \frac{\text { total additional rent } \times[2 \times(\text { occupancy rate })-1]-\text { OEXP }}{\text { Capitalization Rate }}
$$

Value Impacts of Energy Efficiency Retrofits on Commercial Office Buildings in Toronto, Canada | 94 
Using this formula, the financial data types gathered for the case studies in this thesis can be used to determine approximate building value. However, without knowing what proportion of expenses are made up by OEXP versus O\&M costs plus taxes, a final value cannot be reached. 


\section{Conclusions and Further Work}

The intent of this thesis was to strengthen the business case for sustainable building in Canada by determining whether retrofitting existing office buildings would increase their overall value. Canada's existing buildings stock, over half of which had not been retrofitted as of 2009, presents an opportunity for cost-effective investment in energy efficiency and the overall health of our planet.

No previous Canadian studies on this topic have been published to the author's knowledge. Previous U.S. studies had shown that green buildings commanded rental and sale price premia over non-green buildings by analyzing large data sets. In this thesis, a different approach was taken. Instead of comparing green building rents and sales to non-green buildings rents and sales, an in-depth case study approach was taken to compare retrofitted buildings to their pre-retrofit conditions.

The methodology developed in this study can be replicated for any retrofitted building analysis. It is the author's hope that this methodology contributes to the advancement of the study of the relationship between energy efficiency and office building value by making it easier for other researchers to collect data on retrofitted buildings.

Four case studies with rental and energy use data were analyzed in this thesis and it was determined that retrofitting buildings could decrease operating costs, increase occupancy rates, increase effective rental rates (rental revenue). However, these benefits are not necessarily achieved in every case. A larger sample of buildings must be analyzed to make statistically significant conclusions. Access to data, particularly financial data, was a major obstacle to this study. Further work in the form of additional case studies across Canada would greatly benefit this area of research.

It was also determined that occupancy data was critical in the analysis of rental data; without factoring in occupancy rates, previous studies have incorrectly assumed that buildings are converting $100 \%$ of their rental rates into revenue. Real owner-incurred rental revenues are required for the calculation of $\mathrm{NOI}$ and thus building value; a higher rent does not necessarily indicate a higher value.

Finally, a method for incorporating the specific data obtained for this study into simple building value calculations was discussed. The income capitalization approach was selected for this discussion based on available data and level of complexity. It was concluded that effective total additional rent can, for

Civil Engineering UNIVERSITY OF TORONTO
Value Impacts of Energy Efficiency Retrofits on Commercial Office Buildings in Toronto, Canada | 96 
Toronto office buildings, be used as an indicator of value. However, more study on building expenses other than O\&M costs and taxes is required to arrive at final values.

The energy data contained in this thesis are not weather-normalized. Normalized utility data would be useful in correlating the level and energy savings achieved through retrofitting and the level of value increase (O\&M cost decrease, occupancy increase, and/or revenue increase). Further study is recommended to determine whether deeper retrofits with higher energy savings have a more profound impact on value.

Although there has been no legislative action in Canada requiring that building energy be disclosed to the public, this kind of policy implementation would render many existing office buildings less attractive to tenants and, in the case of minimum energy performance requirements, would even render some buildings obsolete. Ahead of this type of action, this research intends to convince industry stakeholders that investing in energy retrofits for commercial office buildings is more than just environmentally responsible; it is a sound financial investment. The addition of building value to the financial analysis tool set will give building owners and investors a more holistic perception of the business case for sustainable buildings. 


\section{References}

[1] S. Persram, M. Lucuik and N. Larsson, "Marketing Green Buildings to Owners of Leased Properties," Canada Green Building Council, 2007.

[2] M. Paris, "Canada only a quarter of the way to greenhouse gas target," CBC News, 19 November 2013. [Online]. Available: http://www.cbc.ca/news/politics/canada-only-a-quarter-of-the-way-togreenhouse-gas-target-1.2431168. [Accessed 22 October 2014].

[3] K. Harris, "Canada failing to meet 2020 emissions targets," CBC News, 24 October 2013. [Online]. Available: http://www.cbc.ca/news/politics/canada-failing-to-meet-2020-emissions-targets1.2223930. [Accessed 22 October 2014].

[4] Environment Canada, "Progress Toward Canada's Greenhouse Gas Emissions Reduction Target," Government of Canada, 11 June 2014. [Online]. Available: https://www.ec.gc.ca/indicateursindicators/default.asp?lang=en\&n=CCED3397-1. [Accessed 14 January 2015].

[5] Natural Resources Canada's Office of Energy Efficiency, "Survey of Commercial and Institutional Energy Use - Buildings 2009 (Detailed Statistical Report December, 2012)," Natural Resources Canda, Ottawa, 2012.

[6] David Gardiner \& Associates, LLC, "Green Buildings and the Finance Sector: An Overview of Financial Institution Involvement in Green Buildings in North America," North American Task Force, UNEP Finance Initiative, Washington, 2010.

[7] J. V. Hughes, "It's Greener to Retrofit than to Build New, Report Finds," National Real Estate Investor, 2012.

[8] T. W. Chappell and C. Corps, "High Performance Green Building: What's it Worth? Investigating the Market Value of High Performance Green Buildings," Cascadia Region Green Building Council, 2009.

[9] K. D. Pressnail and M. F. Touchie, "Building a Better Tomorrow Begins Today! Part II: A Time to Stand Up, Speak Up and Lead," Ontario Building Envelope Council News and Views, 2012.

[10] Natural Resources Canada, "Natural Resources Canada - Buildings and Communities," 23 October 2009. [Online]. Available: http://canmetenergy.nrcan.gc.ca/buildings-communities/2218.

[Accessed March 2013].

[11] Natural Resources Canada, "Energy Use Data Handbook Table," 2012. [Online]. Available: http://oee.nrcan.gc.ca/corporate/statistics/neud/dpa/showTable.cfm?type=HB\&sector=aaa\&juri 
$\mathrm{s}=\mathrm{ca} \& \mathrm{rn}=2$ \&page $=6 \&$ CFID=29773874\&CFTOKEN=1ab8bda06837effb-C33E9904-E9DB-BDC0E954C776EF8189D5. [Accessed 2013].

[12] NRTEE, "Geared for Change: Energy Efficiency in Canada's Commercial Building Sector," National Round Table on the Environment and the Economy and Sustainable Development Technology Canada, Ottawa, 2009.

[13] S. Wilkinson, "Analysing sustainable retrofit potential in premium office buildings," Structural Survey, vol. 30, no. 5, pp. 398-410, 2012.

[14] Canada Green Building Council, LEED Canada for Existing Buildings: Operations and Maintenance 2009 Rating System, Canada Green Building Council, 2009.

[15] M. Gorgolewski, V. Straka and R. Roos, "Survey of the Effectiveness of BOMA BESt and LEED Canada EB:O\&M in Greening the Built Environment in Canada," (Report) Ryerson University Department of Architectural Science Faculty of Engineering and Applied Science, Toronto, 2011.

[16] U.S. Environmental Protection Agency, "About ENERGY STAR," U.S. Environmental Protection Agency, 2014. [Online]. Available: https://www.energystar.gov/about/. [Accessed 12 May 2014].

[17] Natural Resources Canada, "Natural Resources Canada's national building energy benchmarking initiative," Natural Resources Canada, 6 May 2014. [Online]. Available:

http://www.nrcan.gc.ca/energy/efficiency/buildings/energy-benchmarking/3727. [Accessed 12 May 2014].

[18] Natural Resources Canada, "Why ENERGY STAR Portfolio Manager?," Natural Resources Canada, 7 May 2014. [Online]. Available: http://www.nrcan.gc.ca/energy/efficiency/buildings/energybenchmarking/whypm/3729. [Accessed 12 May 2014].

[19] Natural Resources Canada, "All about ENERGY STAR Portfolio Manager," Natural Resources Canada, 1 May 2014. [Online]. Available:

http://www.nrcan.gc.ca/energy/efficiency/buildings/energy-benchmarking/whypm/3733. [Accessed 12 May 2014].

[20] BOMA Canada, "BOMA Canada - About," 2013. [Online]. Available: http://www.bomacanada.ca/about/about_index.html. [Accessed March 2013].

[21] BOMA Canada, "The BOMA BESt Program: An Introduction," January 2013. [Online]. Available: http://www.bomabest.com/wp-content/uploads/The-BOMA-BESt-Program-An-Introduction.pdf. [Accessed March 2013]. 
[22] T. Lützkendorf and D. Lorenz, "Sustainable property investment: valuing sustainable buildings through property performance assessment," Building Research \& Information, vol. 33, no. 3, pp. 212-234, 2005.

[23] E. Miller and L. Buys, "Retrofitting commercial office buildings for sustainability: tenants' perspectives," Journal of Property Investment \& Finance, vol. 26, no. 6, pp. 552-561, 2008.

[24] D. Levy and G. Peterson, "The effect of sustainability on commercial occupiers' building choice," Journal of Property Investment \& Finance, vol. 31, no. 3, pp. 267-284, 2013.

[25] McGraw Hill Construction, "Canada Green Buiding Trends: Benefits Driving the New and Retrofit Market," Canada Green Building Council, 2014.

[26] N. Kok, N. G. Miller and P. Morris, "The Economics of Green Retrofits," The Journal of Sustainable Real Estate, vol. 4, no. 1, pp. 4-22, 2012.

[27] M. Chao, "Recognition of Energy Costs and Energy Performance in Real Property Valuation; Considerations and Resources for Appraisers, Second Edition," Appraisal Institute, 2012.

[28] P. Eichholtz, N. Kok and J. M. Quigley, "Doing Well by Doing Good? Green Office Buildings," The American Economic Review, vol. 100, no. 5, pp. 2492-2509, 2010.

[29] F. Fuerst and P. McAllister, "Green Noise or Green Value? Measuring the Effects of Environmental Certification on Office Values," Real Estate Economics, vol. 39, no. 1, pp. 45-69, 2011.

[30] H. M. Sachs, E. Mendelson and K. Ackerly, "Comprehensive Retrofits of Commercial Office Buildings," ASHRAE Journal, vol. 48, no. 4, pp. 74-75, 2006.

[31] B. Jones and S. M. Bogus, "Decision Process for Energy Efficient Building Retrofits: The Owner's Perspective," Journal of Green Building, vol. 5, no. 3, pp. 131-146, 2009.

[32] C. Kontokosta, "The Emerging Market for Building Energy Retrofits: Navigating the Investment Frontier," Real Estate Finance and Investment, 2011.

[33] REALpac and Jantzi Sustainalytics, "Canadian Commercial Real Estate Sustainability Performance Report," Jantzi Sustainalytics, Toronto, ON, 2010.

[34] L. Ellison, S. Sayce and J. Smith, "Socially Responsible Property Investment: Quantifying the Relationship between Sustainability and Investment Property Worth," Journal of Property Research, vol. 24, no. 3, pp. 191-219, 2007.

[35] M. Lucuik, "A Business Case for Green Buildings in Canada," CaGBC and Morrison Hershfield, 
Ottawa, ON, 2005.

[36] United States Environmental Protection Agency, "Indoor Air Facts No. 4: Sick Building Syndrome," February 1991. [Online]. Available: http://www.epa.gov/iaq/pdfs/sick_building_factsheet.pdf. [Accessed 12 May 2014].

[37] McGraw-Hill Construction, "Green Building SmartMarket Report," McGraw-Hill Construction, 2006.

[38] S. Persram, M. Lucuik and N. Larsson, "Marketing Green Buildings to Tenants of Leased Properties," Canada Green Building Council, 2007.

[39] Johnson Controls, "Institute for Building Efficiency 2013 Energy Efficiency Indicator Survey," June 2013. [Online]. Available:

http://www.johnsoncontrols.com/content/dam/WWW/jci/be/global_workplace_solutions/work place_now_e-zine/June\%202013/061213_IBE_Energy_Efficiency_Indicator_Survey.pdf. [Accessed 20 October 2014].

[40] A. Martin and S. J. Gossett, "Breaking Down Financial Barriers Towards a More Sustainable Commercial Real Estate Market," Strategic Planning for Energy and the Environment, vol. 32, no. 3, pp. 56-65, 2013.

[41] C. E. Kontokosta, "Energy disclosure, market behavior, and the building data ecosystem," Annals of the New York Academy of Sciences, vol. 1295, pp. 34-43, 2013.

[42] plaNYC, "Energy-Aligned Lease Language: Solving the Split Incentive Problem," 13 December 2011. [Online]. Available:

http://www.nyc.gov/html/planyc2030/downloads/pdf/111213_eal_presentation.pdf. [Accessed 22 October 2014].

[43] U.S. Department of Energy, "Better Buildings: Leasing \& Split Incentive," U.S. Department of Energy, 2014. [Online]. Available: http://www4.eere.energy.gov/alliance/activities/marketsolutions-teams/leasing-split-incentive. [Accessed 22 October 2014].

[44] R. Davies, "Green Value: Green buildings, growing assets," Davies Royal Institution of Chartered Surveyors, 2005.

[45] W. Day, "Changes in Commercial Real Estate from Energy Consumption Disclosure," Real Estate Fiannce, pp. 33-35, 2012.

[46] Internat Energy Solutions, "Ontario Building Code Supplementary Standard SB-10," Internat Energy Solutions, 2014. [Online]. Available: 
http://www.internatenergy.com/index.php/en/strategy-a-policy/ontario-buildingsupplementary-standard-sb-10.html. [Accessed 25 October 2014].

[47] A. Jones, "Investigating Deep Retrofits for Toronto's Financial District Office Towers," Journal of Sustainable Real Estate, vol. 5, no. 1, pp. 209-241, 2013.

[48] International Monetary Fund, "International Monetary Fund," 28 January 2013. [Online]. Available: http://www.imf.org/external/np/pp/eng/2013/012813.pdf. [Accessed 22 October 2014].

[49] D. Wong, "Toronto Sustainability Speaker Series (TSSS)," 17 April 2013. [Online]. Available: http://ecoopportunity.net/2013/04/fossil-fuel-subsidies-nearly-800-per-canadian-says-the-imf/. [Accessed 22 October 2014].

[50] Ontario Energy Board, "Natural Gas Rates - Historical," Ontario Energy Board, 25 September 2014. [Online]. Available: http://www.ontarioenergyboard.ca/OEB/Consumers/Natural+Gas/Natural+Gas+Rates/Natural+G as+Rates+-+Historical. [Accessed 19 OctobeR 2014].

[51] Toronto Hydro, "Business Rates," Toronto Hydro, 1 May 2014. [Online]. Available: http://www.torontohydro.com/sites/electricsystem/business/yourbilloverview/Pages/ElectricityR ates.aspx. [Accessed 22 October 2014].

[52] Natural Resources Canada, "Energy Efficiency in Buildings," Natural Resources Canada, 6 October 2014. [Online]. Available: http://www.nrcan.gc.ca/energy/publications/efficiency/buildings/5985. [Accessed 22 October 2014].

[53] Toronto Atmospheric Fund, "Emissions quantification," City of Toronto, 2010. [Online]. Available: http://www1.toronto.ca/wps/portal/contentonly?vgnextoid=f6a87a4bab491410VgnVCM100000 71d60f89RCRD. [Accessed 22 October 2014].

[54] J. Kelsey and D. Pearson, "Updated Procedures for Commercial Building Energy Audits," ASHRAE Transactions, vol. 117, no. 2, pp. 374-381, 2011.

[55] Office of Energy Efficiency \& Renewable Energy, "U.S. Department of Energy," U.S. Department of Energy, 2014. [Online]. Available: http://energy.gov/eere/femp/life-cycle-cost-analysis. [Accessed 5 May 2014].

[56] J. Ouyang, M. Lu, B. Li, C. Wang and K. Hokao, "Economic analysis of upgrading aging residential buildings in China based on dynamic energy consumption and energy price in a market economy," Energy Policy, vol. 39, no. 1, pp. 4902-4910, 2011. 
[57] D. Harvey, "Recent Advances in Sustainable Buildings: Review of the Energy and Cost Performance of the State-of-the-Art Best Practices from Around the World," Annual Review of Environment and Resources, vol. 38, pp. 281-309, 2013.

[58] G. Kats and Capital E, "The Costs and Financial Benefits of Green Building - A Report to California's Sustainable Building Task Force," U.S. Green Building Council, Washington, 2003.

[59] CoStar Realty Information Inc., "About CoStar Group," CoStar Realty Information Inc., 2014. [Online]. Available: http://www.costar.com/about/. [Accessed 5 May 2014].

[60] P. Eichholtz, N. Kok and Q. M. John, "The Economics of Green Building," The Review of Economics and statistics, vol. 95, no. 1, pp. 50-63, 2013.

[61] N. Miller, J. Spivey and A. Florance, "Does Green Pay Off?," Journal of Real Estate Portfolio Management, vol. 14, no. 4, pp. 385-399, 2008.

[62] G. Pivo and J. D. Fisher, "Income, Value, and Returns in Socially Responsible Office Properties," Journal of Real Estate Research, vol. 32, no. 3, pp. 243-270, 2010.

[63] J. A. Wiley, J. D. Benefield and K. H. Johnson, "Green Design and the Market for Commercial Office Space," Journal of Real Estate Finance and Economics, vol. 41, pp. 228-243, 2010.

[64] A. Chegut, P. Eichholtz and N. Kok, "Supply, Demand and the Value of Green Buildings," Urban Studies, vol. 51, no. 1, pp. 22-43, 2014.

[65] R. Clift, "Impact of LEED Certification on Commercial Property Values," St. John's, 2014.

[66] Appraisal Institute of Canada, "Canadian Uniform Standards of Professional Appraisal Practice," 1 January 2012. [Online]. Available: http://staging.aicanada.ca/images/content/file/aic_cuspap\%282012\%29.pdf. [Accessed 29 July 2014].

[67] I. Nase, J. Berry and A. Adair, "Real estate value and quality design in commercial office properties," Journal of European Real Estate Research, vol. 6, no. 1, pp. 48-62, 2013.

[68] D. Lorenz and T. Lützkendorf, "Sustainability and property valuation: Systematisation of existing approaches and recommendations for future action," Journal of Property Investment \& Finance, vol. 29, no. 6, pp. 644-676, 2011.

[69] J. Kimmons, "Capitalization Rates in Real Estate," about.com, 2014. [Online]. Available: http://realestate.about.com/od/ac/g/def_cap_rate.htm. [Accessed 1 November 2014]. 
[70] M. E. Miles, G. L. Berens, M. J. Eppli and M. A. Weiss, Real Estate Development Principles and Process Fourth Edition, Washington, D.C.: Urban Land Institute, 2007.

[71] UBC Real Estate Division, Real Estate Investment Analysis and Advanced Income Appraisal, Vancouver: The University of British Columbia Sauder School of Business, 2008.

[72] Altus Group, "Altus InSite Market Data," Altus Group, 2013. [Online]. Available: http://www.altusgroup.com/research/altus-insite-market-data/. [Accessed 20 November 2014].

[73] Avison Young, "Avison Young Office Market Report Canada \& U.S. Mid-Year 2014," Avison Young, Canada, 2014.

[74] confidential source

[75] confidential source

[76] confidential source

[77] confidential source

[78] confidential source

[79] Environment Canada, "Draft Environmental Code of Practice for Elimination of Fluorocarbon Emissions from Refrigeration and Air Conditioning Systems," Environment Canada, 18 July 2013. [Online]. Available: http://www.ec.gc.ca/Air/default.asp?lang=En\&n=4CA440F8-1. [Accessed 4 November 2014].

[80] confidential source

[81] confidential source

[82] confidential source

[83] confidential source

[84] confidential source

[85] The Independent Electricity System Operator, "Electricity Pricing in Ontario," 2014. [Online]. Available: http://www.ieso.ca/Pages/Ontario\%27s-Power-System/Electricity-Pricing-inOntario/default.aspx. [Accessed 29 October 2014].

[86] Ontario Energy Board, "Natural Gas Rates - Historical (Enbridge Gas Distribution)," Ontario Energy Board, 25 September 2014. [Online]. Available: 
http://www.ontarioenergyboard.ca/OEB/Consumers/Natural+Gas/Natural+Gas+Rates/Natural+G as+Rates+-+Historical. [Accessed 3 October 2014].

[87] confidential source

[88] confidential source

[89] confidential source

[90] confidential source

[91] confidential source

[92] confidential source

[93] confidential source

[94] confidential source

[95] confidential source

[96] confidential source

[97] confidential source

[98] confidential source

[99] confidential source

[100] confidential source

[101] confidential source

[102] confidential source

[103] confidential source

[104] confidential source

[105] confidential source

[106] confidential source 
[107] confidential source

[108] CBRE, "CBRE Canadian Market Outlook 2014," CBRE, Canada, 2014.

[109] A. Damodaran, "Investment Valuation - 2nd Edition," 4 August 2006. [Online]. Available: http://pages.stern.nyu.edu/ adamodar/pdfiles/valn2ed/ch26.pdf. [Accessed 2 November 2014].

[110] A. Morrow, "Financial Post - Analysis: Buyer Beware - Not all green certifications are created equal," 1 March 2013. [Online]. Available: http://business.financialpost.com/2013/03/01/analysis-buyer-beware-not-all-greencertifications-are-created-equal/?_Isa=e117-ebf4. [Accessed March 2013].

[111] Altus Group, "Altus InSite Office Market Definitions," Altus Group, 2010. [Online]. Available: http://www.altusinsite.com/files/docs/Altus-InSite_Definitions_Office.pdf. [Accessed 2 August 2014].

[112] Colliers International, "Colliers International Market Report \& Forecast: Greater Toronto Area Q3 2010 Office," Colliers International, Toronto, 2010.

[113] Colliers International, "Colliers International Market Report Toronto Ontario Fall 2012 Office Sector," Colliers International, Toronto, 2012.

[114] Colliers International, "GTA Office Market Report Third Quarter 2014," Colliers International, Toronto, 2014.

[115] Jones Lang LaSalle, "JLL Canada Research Downtown Toronto Office Insight Q2 2014," Jones Lang LaSalle IP Inc., Toronto, 2014. 


\section{Appendix A - Case Study Questionnaire Template}




\title{
Civil Engineering
}

\section{UNIVERSITY OF TORONTO}

$\begin{array}{lll} & \text { COMMERCIAL BUILDING RESEARCH QUESTIONNAIRE } \\ \text { Author: } & \text { Kaitlin Carlson } & \text { Respondent: } \\ \text { Organization: } & \text { University of Toronto } & \text { Organization: } \\ \text { E-mail: } & \text { k.carlson@mail.utoronto.ca } & \text { E-mail: } \\ & & \text { Date: }\end{array}$

This document is meant to be read in conjunction with "RE: Commercial Building Energy Retrofits and Asset Value Research" which describes the project objectives and information requirements.

\begin{abstract}
CONFIDENTIALITY STATEMENT
Information that you provide will be used for a Masters of Applied Science thesis and subsequent publications. In all instances, building identifiers will be removed. Any identifying information that you provide will be used only by myself, Kaitlin Carlson and my supervisor, Professor K.D. Pressnail and will be held in strict confidence. Data that you provide, less all building identifiers, will be incorporated into my thesis and into journal publications and will be made available to the public. Participation in this study is voluntary and participating organizations may withdraw from the study for any reason at any time.
\end{abstract}

\section{NECESSARY ITEMS}

\section{BUILDING INFORMATION}

\begin{tabular}{|l|l|}
\hline Building Name: & \\
\hline Building Address: & \\
\hline $\begin{array}{l}\text { Building Class: } \\
\text { http://www.altusinsite.com/index.php?page=definitions/office }\end{array}$ & AAA AA A B C \\
\hline Year Built: & \\
\hline Gross Floor Area: & \\
\hline Storeys: & \\
\hline Occupancy types, percentage of occupied space: & \\
\hline Number of Building Occupants (approx.): & \\
\hline$\square$ Building envelope systems description included (consultant report) \\
\hline$\square$ Mechanical systems description included (consultant report) \\
\hline$\square$ Electrical systems description included (consultant report) \\
\hline RETROFIT INFORMATION \\
\hline$\square$ Retrofit consultant reports included \\
\hline$\square$ Energy audit consultant reports included \\
\hline Retrofit year: & \\
\hline Retrofit project cost: & \\
\hline Occupancy \% pre-retrofit: & \\
\hline Occupancy \% post-retrofit: & \\
\hline Rerl & \\
\hline
\end{tabular}

Retrofit description:

ENERGY USE INFORMATION - please provide at least one of (a) or (b)

\begin{tabular}{|l|ll|}
\hline (a) & Pre-retrofit Energy Use Intensity (EUI): & $($ e.g. eKWh/m² \\
\hline & EUI during retrofit: \\
\hline & Post-retrofit EUI: \\
\hline (b) & $\square$ Pre-, during-, and post-retrofit utility bills included (two years pre- and post-retrofit) \\
\hline
\end{tabular}




\section{NECESSARY ITEMS (continued) GREEN CERTIFICATION INFORMATION}

\begin{tabular}{|c|c|}
\hline \multirow{4}{*}{$\begin{array}{l}\text { Pre-retrofit } \\
\text { Year: }\end{array}$} & $\square$ LEED \\
\hline & $\square$ BOMA Best \\
\hline & $\square$ Energy Star: \\
\hline & $\square$ Other: \\
\hline \multirow{4}{*}{$\begin{array}{l}\text { Post-retrofit } \\
\text { Year: }\end{array}$} & $\square$ LEED \\
\hline & $\square$ BOMA Best \\
\hline & $\square$ Energy Star: \\
\hline & $\square$ Other: \\
\hline \multicolumn{2}{|c|}{ FINANCIAL INFORMATION } \\
\hline \multirow[t]{3}{*}{$\operatorname{Rent}\left(\$ / \mathrm{m}^{2}\right)$} & Pre-retrofit: \\
\hline & During-retrofit: \\
\hline & Post-retrofit: \\
\hline
\end{tabular}

Were rents increased/decreased as a result of the energy retrofit? By how much?

Were rents increased/decreased as a result of green certification? By how much?

Did asset value of the building change from pre-retrofit to post-retrofit? By how much (\# or \%)?

\section{ADDITIONAL ITEMS}

Building Asset Value (\$)

Pre-retrofit:

During-retrofit:

Post-retrofit:

Current:

Annual Operating Costs (\$)

Pre-retrofit:

During-retrofit:

Post-retrofit:

Current:

What were the motivations for this energy retrofit?

How would you rate the importance of sustainability to your organization?

$\square$ Not Important $\square$ Somewhat Important $\square$ Neutral $\square$ Important $\quad \square$ Very Important $\quad \square$ Unknown
How would you rate the importance of corporate social responsibility to your organization?
$\square$ Not Important $\square$ Somewhat Important $\square$ Neutral $\square$ Important $\square$ Very Important $\square$ Unknown
How would you rate the importance of sustainability to your tenants?
$\square$ Not Important $\square$ Somewhat Important $\square$ Neutral $\square$ Important $\square$ Very Important $\square$ Unknown




\section{ADDITIONAL ITEMS (continued)}

How would you rate the importance of corporate social responsibility to your tenants?

Not Important $\quad \square$ Somewhat Important $\quad \square$ Neutral $\quad \square$ Important $\quad \square$ Very Important $\square$ Unknown Are any future retrofits planned? Please describe including proposed energy goals and timeline if applicable.

Do you track energy use and costs? At what interval?

Do you benchmark your building's energy use? If so, what baseline do you compare to?

\section{FEEDBACK (optional)}

Length of questionnaire:

Clarity of questionnaire:

Difficulty of questions:

Comments:

Thank you very much for your participation in this research. Please ensure that the following documents are included with your submittal of this questionnaire:

- consultant report with building envelope description;

- consultant report with mechanical systems description;

- consultant report with electrical systems description;

- energy retrofit reports;

- energy audit reports;

- utility bills.

It is my hope that this study and subsequent research will encourage data sharing participation in the commercial building industry and further this area of research. I would be happy to share the result of this project upon completion. Please feel free to contact me should you have any questions or would like to discuss this project.

Sincerely,

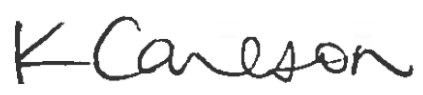

Kaitlin Carlson | MASc Candidate

Department of Civil Engineering | University of Toronto

k.carlson@mail.utoronto.ca | (416) 895-9478 


\section{Appendix B - Case Study Raw Data and Calculations}


BUILDING A DATA $\quad$ (nd = "no data")

(Metric)

ALTUS INSITE RAW DATA

\begin{tabular}{|c|c|c|c|c|c|c|}
\hline & $\begin{array}{l}\text { Total Office } \\
\text { Area }\left(\mathrm{m}^{2}\right)\end{array}$ & $\begin{array}{c}\text { Direct } \\
\text { Asking Rate } \\
\$ / \mathrm{m}^{2}\end{array}$ & $\begin{array}{c}\text { Total } \\
\text { Additional } \\
\text { Rent }\left(\$ / \mathrm{m}^{2}\right)\end{array}$ & $\begin{array}{c}\text { Total } \\
\text { Estimated } \\
\text { Direct Rent } \\
\left(\$ / \mathrm{m}^{2}\right)\end{array}$ & $\begin{array}{c}\text { Total } \\
\text { Available } \\
\text { Area }\left(\mathrm{m}^{2}\right)\end{array}$ & $\begin{array}{c}\text { Total } \\
\text { Available } \\
\text { Rate (\%) }\end{array}$ \\
\hline Q3 2014 & 213,069 & & & & & \\
\hline Q2 2014 & 213,069 & nd & $\$ 323.35$ & nd & 28,356 & 13.3 \\
\hline Q1 2014 & 213,069 & nd & $\$ 323.35$ & nd & 28,543 & 13.4 \\
\hline Q4 2013 & 213,069 & $\$ 330.99$ & $\$ 316.46$ & $\$ 647.45$ & 25,746 & 12.1 \\
\hline Q3 2013 & 213,069 & nd & $\$ 316.46$ & nd & 25,394 & 11.9 \\
\hline Q2 2013 & 213,069 & nd & $\$ 316.46$ & nd & 23,295 & 10.9 \\
\hline Q1 2013 & 213,069 & nd & $\$ 316.46$ & nd & 32,687 & 15.3 \\
\hline Q4 2012 & 213,069 & $\$ 330.99$ & $\$ 316.46$ & $\$ 647.45$ & 31,325 & 14.7 \\
\hline Q3 2012 & 213,069 & nd & $\$ 316.46$ & nd & 30,322 & 14.2 \\
\hline Q2 2012 & 213,069 & nd & $\$ 316.46$ & nd & 30,839 & 14.5 \\
\hline Q1 2012 & 213,069 & nd & $\$ 316.46$ & nd & 30,857 & 14.5 \\
\hline Q4 2011 & 213,069 & $\$ 296.01$ & $\$ 320.76$ & $\$ 616.77$ & 29,892 & 14 \\
\hline Q3 2011 & 213,069 & nd & $\$ 320.76$ & nd & 30,639 & 14.4 \\
\hline Q2 2011 & 213,069 & nd & $\$ 320.76$ & nd & 29,272 & 13.7 \\
\hline Q1 2011 & 213,069 & nd & $\$ 333.25$ & nd & 31,211 & 14.6 \\
\hline Q4 2010 & 213,069 & $\$ 293.32$ & $\$ \quad 333.25$ & $\$ 626.57$ & 25,900 & 12.2 \\
\hline Q3 2010 & 213,069 & nd & $\$ 333.25$ & nd & 25,675 & 12 \\
\hline Q2 2010 & 213,069 & nd & $\$ 333.25$ & nd & 27,499 & 12.9 \\
\hline Q1 2010 & 213,069 & nd & $\begin{array}{ll} & 333.25 \\
\end{array}$ & nd & 29,684 & 13.9 \\
\hline Q4 2009 & 213,069 & $\$ 328.30$ & $\$ 333.25$ & $\$ 661.55$ & 32,097 & 15.1 \\
\hline Q3 2009 & 213,069 & nd & $\$ \quad 334.65$ & nd & 29,037 & 13.6 \\
\hline Q2 2009 & 213,069 & nd & $\$ \quad 334.65$ & nd & 29,196 & 13.7 \\
\hline Q1 2009 & 213,069 & nd & $\$ 334.65$ & nd & 26,527 & 12.4 \\
\hline Q4 2008 & 213,069 & nd & $\$ 334.65$ & nd & 26,119 & 12.3 \\
\hline Q3 2008 & 213,069 & nd & $\$ \quad 323.78$ & nd & 27,051 & 12.7 \\
\hline Q2 2008 & 213,069 & nd & $\$ \quad 323.78$ & nd & 14,077 & 6.6 \\
\hline Q1 2008 & 213,069 & nd & $\$ 323.78$ & nd & 10,855 & 5.1 \\
\hline Q4 2007 & 213,069 & $\$ 322.92$ & $\$ 323.78$ & $\$ 646.70$ & 13,598 & 6.4 \\
\hline Q3 2007 & 213,069 & $\$ 344.44$ & $\$ 322.06$ & $\$ 666.50$ & 13,787 & 6.5 \\
\hline Q2 2007 & 213,069 & $\$ 344.44$ & $\$ 322.06$ & $\$ 666.50$ & 17,028 & 8 \\
\hline Q1 2007 & 213,069 & $\$ 344.44$ & $\$ 322.16$ & $\$ 666.61$ & 20,333 & 9.5 \\
\hline Q4 2006 & 213,069 & $\$ 344.44$ & $\$ 322.06$ & $\$ 666.50$ & 28,710 & 13.5 \\
\hline Q3 2006 & 213,069 & $\$ 344.44$ & \$ 316.46 & $\$ 660.90$ & 15,705 & 7.4 \\
\hline Q2 2006 & 213,069 & $\$ 344.44$ & 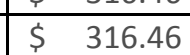 & $\$ 660.90$ & 18,679 & 8.8 \\
\hline Q1 2006 & 213,069 & $\$ 344.44$ & $\$ 316.46$ & $\$ 660.90$ & 18,915 & 8.9 \\
\hline Q4 2005 & 213,069 & $\$ 344.44$ & $\$ 316.46$ & $\$ 660.90$ & 14,334 & 6.7 \\
\hline Q3 2005 & 213,069 & $\$ 344.44$ & $\begin{array}{l}\$ 309.57 \\
\end{array}$ & $\$ 654.01$ & 12,127 & 5.7 \\
\hline Q2 2005 & 213,069 & $\$ 344.44$ & $\$ 309.57$ & $\$ 654.01$ & 8,986 & 4.2 \\
\hline 012005 & 213,069 & $\$ 344.44$ & \begin{tabular}{|ll} 
& 309.57
\end{tabular} & $\$ 654.01$ & 16,366 & 7.7 \\
\hline
\end{tabular}

* 2014 Altus Insite Data included only the first two quarters
ALTUS INSITE ANNUAL AVERAGE DATA

\begin{tabular}{|c|c|c|c|c|c|c|c|c|}
\hline & $\begin{array}{c}\text { Direct } \\
\text { Asking Rate } \\
\$ / \mathrm{m}^{2}\end{array}$ & $\begin{array}{c}\text { Total } \\
\text { Additional } \\
\text { Rent }\left(\$ / \mathrm{m}^{2}\right)\end{array}$ & $\begin{array}{c}\text { Total } \\
\text { Estimated } \\
\text { Direct Rent } \\
\left(\$ / \mathrm{m}^{2}\right)\end{array}$ & \begin{tabular}{|c|} 
Total \\
Available \\
Area $\left(\mathrm{m}^{2}\right)$
\end{tabular} & $\begin{array}{l}\text { Total } \\
\text { Available } \\
\text { Rate (\%) }\end{array}$ & $\begin{array}{c}\text { Occupancy } \\
\text { Rate }\end{array}$ & $\begin{array}{c}\text { Effective Total } \\
\text { Additional } \\
\text { Rent }\left(\$ / \mathrm{m}^{2}\right)\end{array}$ & \begin{tabular}{|c} 
Effective Total \\
Estimated Direct \\
Rent $\left(\$ / \mathrm{m}^{2}\right)$
\end{tabular} \\
\hline$\longdiv { 2 0 1 4 }$ & nd & $\$ 323.35$ & nd & 28,356 & $13.3 \%$ & $86.7 \%$ & $\$ 280.32$ & nd \\
\hline 2013 & $\$ 330.99$ & $\$ 316.46$ & $\$ 647.45$ & 25,746 & $12.1 \%$ & $87.9 \%$ & $\$ 278.22$ & $\$ 569.21$ \\
\hline 2012 & $\$ 330.99$ & $\$ 316.46$ & $\$ 647.45$ & 31,325 & $14.7 \%$ & $85.3 \%$ & $\$ 269.93$ & $\$ 552.26$ \\
\hline 2011 & $\$ 296.01$ & $\$ 320.76$ & $\$ 616.77$ & 29,892 & $14.0 \%$ & $86.0 \%$ & $\$ 275.76$ & $\$ 530.24$ \\
\hline 2010 & $\$ 293.32$ & $\$ 333.25$ & $\$ 626.57$ & 25,900 & $12.2 \%$ & $87.8 \%$ & $\$ 292.74$ & $\$ 550.40$ \\
\hline 2009 & $\$ 328.30$ & $\$ 333.25$ & $\$ 661.55$ & 32,097 & $15.1 \%$ & $84.9 \%$ & $\$ 283.05$ & $\$ 561.89$ \\
\hline 2008 & nd & $\$ 334.65$ & nd & 26,119 & $12.3 \%$ & $87.7 \%$ & $\$ 293.63$ & $\mathrm{nd}$ \\
\hline 2007 & $\$ 322.92$ & $\$ 323.78$ & $\$ 646.70$ & 13,598 & $6.4 \%$ & $93.6 \%$ & $\$ 303.11$ & $\$ 605.42$ \\
\hline 2006 & $\$ 344.44$ & $\$ 322.06$ & $\$ 666.50$ & 28,710 & $13.5 \%$ & $86.5 \%$ & $\$ 278.66$ & $\$ 576.69$ \\
\hline 2005 & $\$ 344.44$ & $\$ 316.46$ & $\$ 660.90$ & 14,334 & $6.7 \%$ & $93.3 \%$ & $\$ 295.17$ & $\$ 616.44$ \\
\hline
\end{tabular}

Direct Asking Rate $=$ net rental rate (excludes $0 \& M$ costs and taxes)

Additional Rent $=$ O\&M costs and taxes

BUILDING A FINANCIAL CALCULATIONS

\begin{tabular}{|c|c|c|c|}
\hline & $\begin{array}{l}\text { \% Add. } \\
\text { Rent }\end{array}$ & $\begin{array}{c}\text { \% Direct } \\
\text { Asking Rate }\end{array}$ & \\
\hline 2014 & nd & nd & \% Direct Asking \\
\hline 2013 & $48.9 \%$ & $51.1 \%$ & \\
\hline 2012 & $48.9 \%$ & $51.1 \%$ & \\
\hline 2011 & $52.0 \%$ & $48.0 \%$ & \\
\hline 2010 & $53.2 \%$ & $46.8 \%$ & \\
\hline 2009 & $50.4 \%$ & $49.6 \%$ & retrofit year \\
\hline 2008 & nd & nd & \\
\hline 2007 & $50.1 \%$ & $49.9 \%$ & \\
\hline 2006 & $48.3 \%$ & $51.7 \%$ & \\
\hline 2005 & $47.9 \%$ & $52.1 \%$ & \\
\hline MIN & $47.9 \%$ & $46.8 \%$ & \\
\hline MAX & $53.2 \%$ & $52.1 \%$ & \\
\hline AVERAGE & $49.9 \%$ & $50.1 \%$ & \\
\hline
\end{tabular}

percentage of Total Estimated Direct Rent attributed to Total $=$ Total Additional Rent $\div$ Total Estimated Direct Ren

Rent attributed to Direct Asking Rate (Base Rent) $=$ Direct Asking Rate $\div$ Total Estimated Direct Rent
$10.7639 \mathrm{ft}^{2}=1 \mathrm{~m}^{2}$ 


\section{BUILDING A DATA}

(Metric)

RGY DATA (BOMA)

POST-RETROFIT

\begin{tabular}{|c|c|c|c|c|}
\hline Month & $\begin{array}{l}\text { Natural } \\
\text { Gas }\left(m^{3}\right)\end{array}$ & Natural Gas (\$) & $\begin{array}{l}\text { Electricity } \\
\text { (kWh) }\end{array}$ & Electricity $(\$)$ \\
\hline Jun-09 & 82,352 & $\$ 34,125.00$ & $8,578,904$ & $\$ 704,500.00$ \\
\hline Jul-09 & 4,524 & $\$ 1,999.00$ & $8,863,904$ & $\$ 784,932.00$ \\
\hline Aug-09 & 3,711 & $\$ 1,645.00$ & $8,695,761$ & $\$ 934,862.00$ \\
\hline Sep-09 & 3,411 & $\$ 1,519.00$ & $8,272,265$ & $\$ 750,667.00$ \\
\hline Oct-09 & 3,399 & $\$ 1,513.00$ & $8,195,782$ & $\$ 875,690.00$ \\
\hline Nov-09 & 31,362 & $\$ 12,624.00$ & $7,927,885$ & $\$ 751,572.00$ \\
\hline \begin{tabular}{|l} 
Dec-099 \\
\end{tabular} & 159,175 & $\$ 53,780.00$ & $8,242,895$ & $\$ 891,466.00$ \\
\hline Jan-10 & 454,115 & $\$ 153,349.00$ & $8,182,559$ & $\$ 836,428.00$ \\
\hline Feb-10 & 584,373 & $\$ 200,749.00$ & $7,513,309$ & $\$ 776,119.00$ \\
\hline Mar-10 & 573,280 & $\$ 196,942.00$ & $8,142,332$ & $\$ 721,892.00$ \\
\hline Apr-10 & 168,812 & $\$ 58,066.00$ & $7,548,453$ & $\$ 851,722.00$ \\
\hline May-10 & 189,398 & $\$ 64,244.00$ & $7,671,090$ & $\$ 855,941.00$ \\
\hline Total & $2,257,912$ & $\$ 780,555.00$ & $97,835,139$ & $\$ 9,735,791.00$ \\
\hline
\end{tabular}

*Electrical Demand (kW) not provided

\section{BOMA CALCULATIONS}

$$
\begin{array}{rr}
\text { EUI } & 43.21 \mathrm{ekWh} / \mathrm{ft}^{2}-\mathrm{yr} \\
& 465.1 \mathrm{ekWh} / \mathrm{m}^{2}-\mathrm{yr} \\
\text { GHG emissions } & 34,624.80 \text { tonnes } / \mathrm{yr}
\end{array}
$$$$
\left(\mathrm{CO}_{2}\right. \text { eq) }
$$

\section{ENERGY CALCULATIONS (BOMA)}

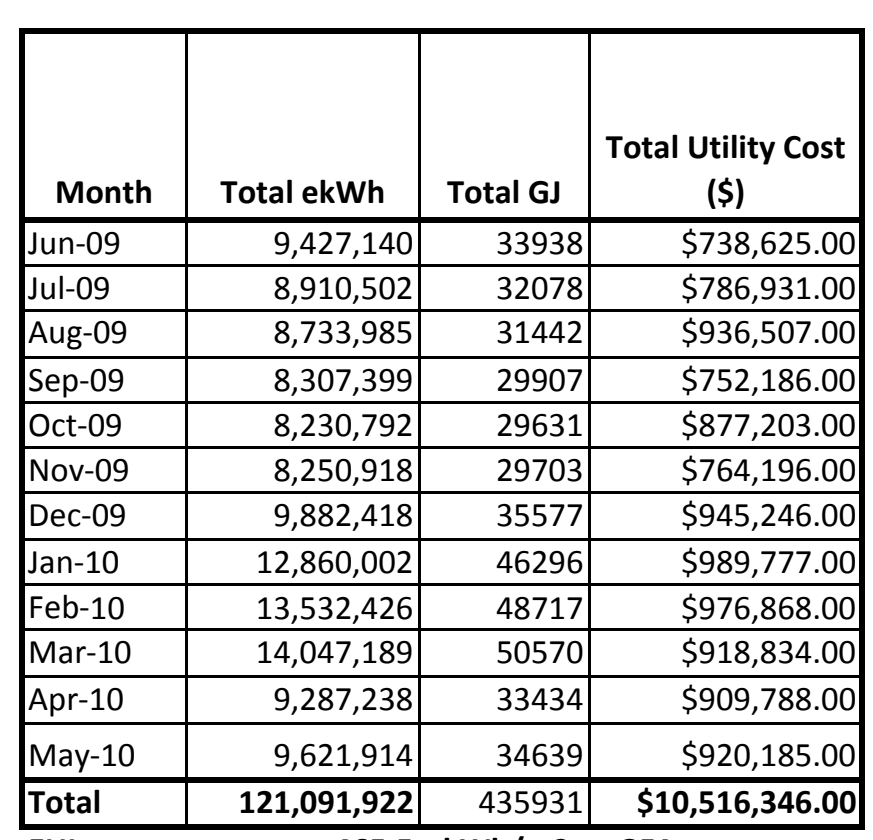

EUI $\quad 465.5 \mathrm{ekWh} / \mathrm{m2}$-yr GFA

1.6758274 GJ/m2-yr GFA
RETROFIT DATA (public sources)

PROJECTED SAVINGS

Self-reported savings by property management company (no normalization, absolute

consumption data used):

Energy consumption reduction: $\quad 25 \% \quad 2013$ vs 2008

Energy consumption reduction: $\quad 32 \%-2012$ vs 2009

GHG emission reduction: $\quad 35 \%-2013$ vs 2008

Water consumption reduction: $\quad 36 \% \quad 2013$ vs 2008

Energy Star Rating: $\quad \sim \quad 80 \% \quad 2014$

Toronto Atmospheric Fund (TAF) 2011:

Energy consumption reduction: $\quad 19,400,000$ ekWh annually compared to 2009 baseline

$0.26848242 \mathrm{GJ} / \mathrm{m} 2$-yr GFA

GHG emissions reduction: $\quad 27,000$ tonnes $\mathrm{CO}_{2}$ eq annually compared to 2009 baseline

CivicAction Alliance 2011

Cost Index

\section{$\$ 40.43 \$ / m 2-y r$ GFA}

$20 \%$ annually
0.133 tonnes $/ \mathrm{m}^{2}-\mathrm{yr}$

$\begin{aligned} 1 \mathrm{GJ} & =26.968381 \mathrm{~m}^{3} \text { natural gas }\left(\text { NRCan, NED }^{2}\right) \\ 1 \mathrm{GJ} & =277.77778 \mathrm{ekWh} \\ \therefore 1 \mathrm{~m}^{3} \text { natural gas } \approx & 10.300128 \mathrm{ekWh}\end{aligned}$

$1.67582743 \mathrm{GJ} / \mathrm{m} 2-y \mathrm{r}$ GFA $\quad 2009 / 2010$ $94430985 \mathrm{GJ} / \mathrm{m} 2-\mathrm{yr}$ GFA

$13.8 \%$ energy consumption reduction through retrofit

Post-retrofit EUI (BOMA):

\begin{tabular}{|lr|}
\hline GFA: & $2800000 \mathrm{ft}^{2}$ \\
(BOMA) & $260129 \mathrm{~m}^{2}$ \\
\hline
\end{tabular}

\begin{tabular}{|l|r|}
\hline $\begin{array}{l}\text { Annual Energy Savings Summary vs } 2009 \\
\text { Baseline, Various Sources }\end{array}$ \\
\hline TAF & $13.8 \%$ \\
\hline CivicAction Alliance & $20 \%$ \\
\hline Self-reported & $32 \%$ \\
\hline
\end{tabular}

(BOMA)

${ }^{2}$

Self-reported

$32 \%$ 


\begin{tabular}{|c|c|c|c|c|c|c|}
\hline & $\begin{array}{l}\text { Total Office } \\
\text { Area }\left(\mathrm{m}^{2}\right)\end{array}$ & \begin{tabular}{|c|} 
Direct \\
Asking Rate \\
$\$ / \mathrm{m}^{2}$
\end{tabular} & \begin{tabular}{|c|} 
Total \\
Additional \\
Rent $\left(\mathbf{\$} / \mathrm{m}^{2}\right)$ \\
\end{tabular} & $\begin{array}{c}\text { Total } \\
\text { Estimated } \\
\text { Direct Rent } \\
\left(\$ / \mathrm{m}^{2}\right)\end{array}$ & $\begin{array}{c}\text { Total } \\
\text { Available } \\
\text { Area }\left(\mathrm{m}^{2}\right)\end{array}$ & $\begin{array}{c}\text { Total } \\
\text { Available } \\
\text { Rate (\%) }\end{array}$ \\
\hline Q3 2014 & 90,663 & & & & & \\
\hline Q2 2014 & 90,663 & nd & $\begin{array}{|ll|}\$ 353.06 \\
\end{array}$ & nd & 6,404 & 7.1 \\
\hline Q1 2014 & 90,663 & nd & \begin{tabular}{|l|}
$\$ 353.06$ \\
\end{tabular} & nd & 6,922 & 7.6 \\
\hline Q4 2013 & 90,663 & $\$ 322.92$ & $\begin{array}{|ll|}\$ 353.06 \\
\end{array}$ & $\$ 675.97$ & 6,543 & 7.2 \\
\hline Q3 2013 & 90,663 & nd & $\begin{array}{|ll|}\$ & 342.29 \\
\end{array}$ & nd & 6,572 & 7.2 \\
\hline Q2 2013 & 90,663 & nd & $\begin{array}{|ll|}\$ & 342.29 \\
\end{array}$ & nd & 3,911 & 4.3 \\
\hline Q1 2013 & 90,663 & nd & $\begin{array}{|ll|}\$ & 342.29 \\
\end{array}$ & nd & 4,597 & 5.1 \\
\hline Q4 2012 & 90,663 & $\$ 320.23$ & $\begin{array}{|ll|}\$ & 342.29 \\
\end{array}$ & $\$ 662.52$ & 4,913 & 5.4 \\
\hline Q3 2012 & 90,663 & nd & $\begin{array}{|ll|}\$ & 342.29 \\
\end{array}$ & nd & 1,733 & 1.9 \\
\hline Q2 2012 & 90,663 & nd & $\begin{array}{|ll|}\$ & 336.91 \\
\end{array}$ & nd & 10,898 & 12 \\
\hline Q1 2012 & 90,663 & nd & $\begin{array}{|ll|}\$ & 340.68 \\
\end{array}$ & nd & 12,492 & 13.8 \\
\hline Q4 2011 & 90,663 & nd & $\begin{array}{|ll|}\$ & 340.68 \\
\end{array}$ & nd & 25,955 & 28.6 \\
\hline Q3 2011 & 90,663 & nd & $\begin{array}{|ll|}\$ & 340.68 \\
\end{array}$ & nd & 30,296 & 33.4 \\
\hline Q2 2011 & 90,663 & nd & $\begin{array}{|ll|}\$ & 340.68 \\
\end{array}$ & nd & 30,203 & 33.3 \\
\hline Q1 2011 & 90,663 & nd & \begin{tabular}{|l|}
$\$ 340.68$ \\
\end{tabular} & nd & 32,265 & 35.6 \\
\hline Q4 2010 & 90,663 & nd & $\begin{array}{|ll|}\$ & 340.68 \\
\end{array}$ & nd & 34,461 & 38 \\
\hline Q3 2010 & 90,663 & nd & \begin{tabular}{|l|}
$\$ 340.68$ \\
\end{tabular} & nd & 44,495 & 49.1 \\
\hline Q2 2010 & 90,663 & nd & $\begin{array}{|ll|}\$ & 340.68 \\
\end{array}$ & nd & 44,397 & 49 \\
\hline Q1 2010 & 90,663 & nd & $\begin{array}{|ll|}\$ 340.68 \\
\end{array}$ & nd & 23,641 & 26.1 \\
\hline Q4 2009 & 90,663 & nd & $\begin{array}{|ll|}\$ 340.68 \\
\end{array}$ & nd & 23,641 & 26.1 \\
\hline Q3 2009 & 90,663 & $\$ 333.68$ & $\begin{array}{|ll|}\$ & 347.67 \\
\end{array}$ & $\$ 681.35$ & 24,884 & 27.4 \\
\hline Q2 2009 & 90,663 & $\$ 333.68$ & $\begin{array}{|ll|}\$ & 347.67 \\
\end{array}$ & $\$ 681.35$ & 20,773 & 22.9 \\
\hline Q1 2009 & 90,663 & $\$ 333.68$ & $\begin{array}{|ll|}\$ & 345.52 \\
\end{array}$ & $\$ 679.20$ & 14,213 & 15.7 \\
\hline Q4 2008 & 90,663 & $\$ 333.68$ & $\begin{array}{|ll|}\$ 345.52 \\
\end{array}$ & $\$ 679.20$ & 14,213 & 15.7 \\
\hline Q3 2008 & 90,663 & $\$ 333.68$ & $\begin{array}{|ll|}\$ & 345.63 \\
\end{array}$ & $\$ 679.31$ & 14,213 & 15.7 \\
\hline Q2 2008 & 90,663 & $\$ 333.68$ & $\begin{array}{|ll|}\$ 345.63 \\
\end{array}$ & $\$ 679.31$ & 14,213 & 15.7 \\
\hline Q1 2008 & 90,663 & $\$ 333.68$ & $\begin{array}{|ll|}\$ 345.63 \\
\end{array}$ & $\$ 679.31$ & 14,213 & 15.7 \\
\hline Q4 2007 & 90,663 & $\$ 333.68$ & $\begin{array}{|ll|}\$ 336.05 \\
\end{array}$ & $\$ 669.73$ & 34,741 & 38.3 \\
\hline Q3 2007 & 90,663 & $\$ 333.68$ & $\begin{array}{|ll|}5 & 336.05 \\
\end{array}$ & $\$ 669.73$ & 37,731 & 41.6 \\
\hline Q2 2007 & 90,663 & $\$ 333.68$ & $\begin{array}{|ll|}\$ & 325.61 \\
\end{array}$ & $\$ 659.29$ & 39,138 & 43.2 \\
\hline Q1 2007 & 90,663 & $\$ 333.68$ & \begin{tabular}{|l|}
$\$ 325.61$ \\
\end{tabular} & $\$ 659.29$ & 40,222 & 44.4 \\
\hline Q4 2006 & 90,663 & $\$ 333.68$ & $\begin{array}{|ll|}\$ & 325.61 \\
\end{array}$ & $\$ 659.29$ & 36,098 & 39.8 \\
\hline Q3 2006 & 90,663 & $\$ 333.68$ & $\begin{array}{|ll|}\$ 325.61 \\
\end{array}$ & $\$ 659.29$ & 36,098 & 39.8 \\
\hline Q2 2006 & 90,663 & $\$ 322.92$ & $\begin{array}{|ll|}\$ & 325.61 \\
\end{array}$ & $\$ 648.52$ & 2,281 & 2.5 \\
\hline Q1 2006 & 90,663 & $\$ 322.92$ & \begin{tabular}{|l|}
$\$ 325.61$ \\
\end{tabular} & $\$ 648.52$ & 5,413 & 6 \\
\hline Q4 2005 & 90,663 & $\$ 322.92$ & $\begin{array}{|ll|}\$ & 325.61 \\
\end{array}$ & $\$ 648.52$ & 9,153 & 10.1 \\
\hline Q3 2005 & 90,663 & $\$ 322.92$ & $\begin{array}{|ll|}\$ & 319.15 \\
\end{array}$ & $\$ 642.07$ & 9,111 & 10 \\
\hline Q2 2005 & 90,663 & $\$ 312.15$ & $\begin{array}{|ll|}\$ & 319.15 \\
\end{array}$ & $\$ 631.30$ & 9,111 & 10 \\
\hline Q1 2005 & 90,663 & $\$ 312.15$ & $\begin{array}{|ll|}\$ & 319.15 \\
\end{array}$ & $\$ 631.30$ & 9,323 & 10.3 \\
\hline
\end{tabular}

\begin{tabular}{|c|c|c|c|c|c|c|c|c|}
\hline & $\begin{array}{c}\text { Direct } \\
\text { Asking } \\
\text { Rate } \$ / \mathrm{m}^{2}\end{array}$ & $\begin{array}{c}\text { Total } \\
\text { Additional } \\
\text { Rent }\left(\$ / \mathrm{m}^{2}\right) \\
\end{array}$ & $\begin{array}{c}\text { Total } \\
\text { Estimated } \\
\text { Direct Rent } \\
\left(\$ / \mathrm{m}^{2}\right) \\
\end{array}$ & \begin{tabular}{|c} 
Total \\
Available \\
Area $\left(\mathrm{m}^{2}\right)$ \\
\end{tabular} & $\begin{array}{c}\text { Total } \\
\text { Available } \\
\text { Rate (\%) } \\
\end{array}$ & $\begin{array}{c}\begin{array}{c}\text { Occupancy } \\
\text { Rate }\end{array} \\
\end{array}$ & \begin{tabular}{|c} 
Effective Total \\
Additional Rent \\
$\left(\$ / \mathrm{m}^{2}\right)$
\end{tabular} & $\begin{array}{c}\text { Effective Total } \\
\text { Estimated Direct } \\
\text { Rent }\left(\$ / \mathrm{m}^{2}\right) \\
\end{array}$ \\
\hline 2014 & nd & $\$ 353.06$ & nd & 6,404 & $7.1 \%$ & $92.9 \%$ & $\$ 328.12$ & nd \\
\hline 2013 & $\$ 322.92$ & $\$ 353.06$ & $\$ 675.97$ & 6,543 & $7.2 \%$ & $92.8 \%$ & $\$ 327.58$ & $\$ 627.19$ \\
\hline 2012 & $\$ 320.23$ & $\$ 342.29$ & $\$ 662.52$ & 4,913 & $5.4 \%$ & $94.6 \%$ & $\$ 323.74$ & $\$ 626.62$ \\
\hline 2011 & nd & $\$ 340.68$ & nd & 25,955 & $28.6 \%$ & $71.4 \%$ & $\$ 243.15$ & nd \\
\hline 2010 & nd & $\$ 340.68$ & nd & 34,461 & $38.0 \%$ & $62.0 \%$ & $\$ 211.19$ & nd \\
\hline 2009 & $\$ 333.68$ & $\$ 340.68$ & $\$ 681.35$ & 23,641 & $26.1 \%$ & $73.9 \%$ & $\$ 251.84$ & $\$ 503.69$ \\
\hline 2008 & $\$ 333.68$ & $\$ 345.52$ & $\$ 679.20$ & 14,213 & $15.7 \%$ & $84.3 \%$ & $\$ 291.35$ & $\$ 572.72$ \\
\hline 2007 & $\$ 333.68$ & $\$ 336.05$ & $\$ 669.73$ & 34,741 & $38.3 \%$ & $61.7 \%$ & $\$ 207.28$ & $\$ 413.10$ \\
\hline 2006 & $\$ 333.68$ & $\$ 325.61$ & $\$ 659.29$ & 36,098 & $39.8 \%$ & $60.2 \%$ & $\$ 195.97$ & $\$ 396.79$ \\
\hline 2005 & $\$ 322.92$ & $\$ 325.61$ & $\$ 648.52$ & 9,153 & $10.1 \%$ & $89.9 \%$ & $\$ 292.74$ & $\$ 583.05$ \\
\hline
\end{tabular}

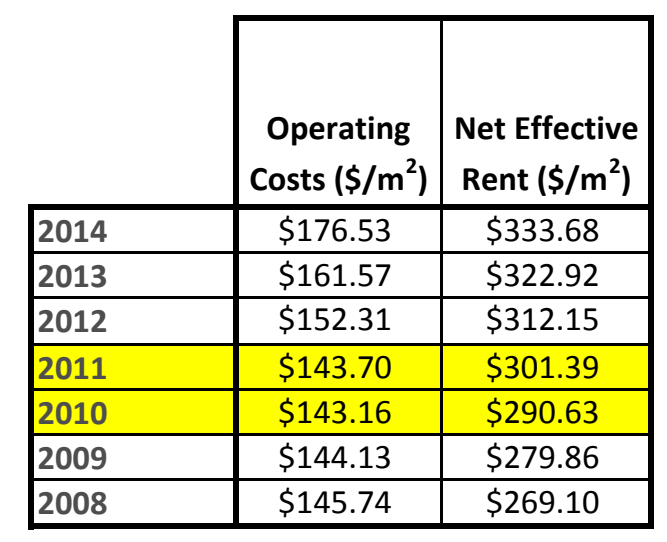

* Q4 data except 2014 is Q2 data 2009 rent is Q1-Q3 data (constant rent assumed through the year)

Direct Asking Rate $=$ net rental rate (excludes O\&M costs and taxes)

Additional Rent $=0 \& M$ costs and taxes

BUILDING B FINANCIAL CALCULATIONS

$10.7639 \mathrm{ft}^{2}=1 \mathrm{~m}^{2}$

\begin{tabular}{|c|c|c|}
\cline { 2 - 3 } \multicolumn{1}{c|}{} & $\begin{array}{c}\text { \% Add. } \\
\text { Rent }\end{array}$ & $\begin{array}{c}\text { \% Op. Costs of } \\
\text { Total Add. Rent }\end{array}$ \\
\hline 2014 & nd & $50.0 \%$ \\
\hline 2013 & $52.2 \%$ & $45.8 \%$ \\
\hline 2012 & $51.7 \%$ & $44.5 \%$ \\
\hline 2011 & nd & $42.2 \%$ \\
\hline 2010 & nd & $42.0 \%$ \\
\hline 2009 & $50.0 \%$ & $42.3 \%$ \\
\hline 2008 & $50.9 \%$ & $42.2 \%$ \\
\hline 2007 & $50.2 \%$ & retrofofit year \\
\hline 2006 & $49.4 \%$ & nd \\
\hline 2005 & $50.2 \%$ & nd \\
\hline MIN & $49.4 \%$ & $\mathbf{4 2 . 0 \%}$ \\
\hline MAX & $\mathbf{5 2 . 2} \%$ & $\mathbf{5 0 . 0 \%}$ \\
\hline AVG & $\mathbf{5 0 . 6 \%}$ & $\mathbf{4 4 . 1 \%}$ \\
\hline
\end{tabular}

$\%$ Add. Rent $\quad=$ percentage of Total Estimated Direct Rent attributed to Total Additional Rent (O\&M costs and taxes)

$$
=\text { Total Additional Rent } \div \text { Total Estimated Direct Rent }
$$

$\%$ Additional Rent ranges between $49.4 \%$ and $52.2 \%$ of Total Estimated Direct Rent (average 50.6\%).

$\%$ Op. Costs of Total Add. Rent

$=$ percentage of Total Additional Rent (O\&M costs and taxes) attributed to Operating Cos $=$ Operating Costs $\div$ Total Additional Rent

$\%$ Op. Costs of Total Add. Rent ranges between $42.0 \%$ and $50.0 \%$ of Total Estimated Direct Rent (average $44.1 \%$ ) and is on the rise post-retrofit because of large increases in utility costs.

Conclusion: acceptable to assume operating costs follow roughly the same trends as total additional rent. 


\begin{tabular}{|c|c|c|c|c|c|c|c|c|c|c|c|}
\hline & $\begin{array}{c}\text { Natural } \\
\text { Gas } \\
\left(\mathbf{m}^{\mathbf{3}}\right)\end{array}$ & $\begin{array}{c}\text { Natural } \\
\text { Gas } \mathbf{( \$ )}\end{array}$ & $\begin{array}{c}\text { Electricity } \\
\mathbf{( k W h )}\end{array}$ & $\begin{array}{c}\text { Electricity } \\
(\mathbf{k W})\end{array}$ & $\begin{array}{c}\text { Electricity } \\
(\mathbf{k V A})\end{array}$ & $\begin{array}{c}\text { Electricity } \\
\mathbf{( \$ )}\end{array}$ & Steam (lbs) & Steam (\$) & $\begin{array}{c}\text { CHW (ton } \\
\text { hours) }\end{array}$ & $\begin{array}{c}\text { CHW (\$) } \\
\text { Month }\end{array}$ & $\begin{array}{c}\text { Power } \\
\text { Factor }\end{array}$ \\
\hline Jul-09 & 0 & $\$ 0$ & $1,921,279$ & 3,666 & 4,331 & $\$ 160,436$ & 200,000 & $\$ 72,956$ & 493,230 & $\$ 79,332$ & $90.20 \%$ \\
\hline Aug-09 & 0 & $\$ 0$ & $1,891,072$ & 3,694 & 4,097 & $\$ 188,560$ & 0 & $\$ 38,158$ & 545,430 & $\$ 87,888$ & $84.70 \%$ \\
\hline Sep-09 & 0 & $\$ 0$ & $1,735,068$ & 3,550 & 4,191 & $\$ 148,502$ & 0 & $\$ 38,156$ & 351,270 & $\$ 66,758$ & $88.40 \%$ \\
\hline Oct-09 & 0 & $\$ 0$ & $1,633,040$ & 3,462 & 3,917 & $\$ 166,718$ & 42,825 & $\$ 38,901$ & 201,680 & $\$ 50,180$ & $88.40 \%$ \\
\hline Nov-09 & 0 & $\$ 0$ & $1,577,191$ & 3,227 & 3,650 & $\$ 141,980$ & 413,406 & $\$ 45,349$ & 167,560 & $\$ 44,234$ & $91.30 \%$ \\
\hline Dec-09 & 0 & $\$ 0$ & $1,576,632$ & 3,263 & 3,572 & $\$ 162,891$ & $2,918,560$ & $\$ 88,939$ & 74,300 & $\$ 32,905$ & $89.90 \%$ \\
\hline Jan-10 & 0 & $\$ 0$ & $1,603,222$ & 3,219 & 3,582 & $\$ 155,095$ & $3,912,001$ & $\$ 106,225$ & 97,970 & $\$ 37,371$ & $89.60 \%$ \\
\hline Feb-10 & 0 & $\$ 0$ & $1,401,344$ & 2,794 & 3,119 & $\$ 137,465$ & $4,914,997$ & $\$ 123,677$ & 95,520 & $\$ 37,098$ & $90 \%$ \\
\hline Mar-10 & 0 & $\$ 0$ & $1,565,539$ & 3,079 & 3,423 & $\$ 131,104$ & $7,044,003$ & $\$ 159,595$ & 104,390 & $\$ 37,840$ & $88.70 \%$ \\
\hline Apr-10 & 0 & $\$ 0$ & $1,465,872$ & 3,020 & 3,405 & $\$ 157,296$ & $10,282,085$ & $\$ 240,302$ & 282,230 & $\$ 61,720$ & $89.10 \%$ \\
\hline May-10 & 0 & $\$ 0$ & $1,461,171$ & 3,193 & 3,583 & $\$ 156,074$ & $8,801,001$ & $\$ 156,052$ & 376,960 & $\$ 75,591$ & $88.80 \%$ \\
\hline Jun-10 & 0 & $\$ 0$ & $1,440,117$ & 3,022 & 3,405 & $\$ 135,948$ & $4,408,295$ & $\$ 114,860$ & 354,630 & $\$ 70,868$ & nd \\
\hline Total & & & $19,271,547$ & 39,189 & 44,275 & $\$ 1,842,069$ & $42,937,173$ & $\$ 1,223,170$ & $3,145,170$ & $\$ 681,785$ & $89.01 \%$ \\
\hline
\end{tabular}

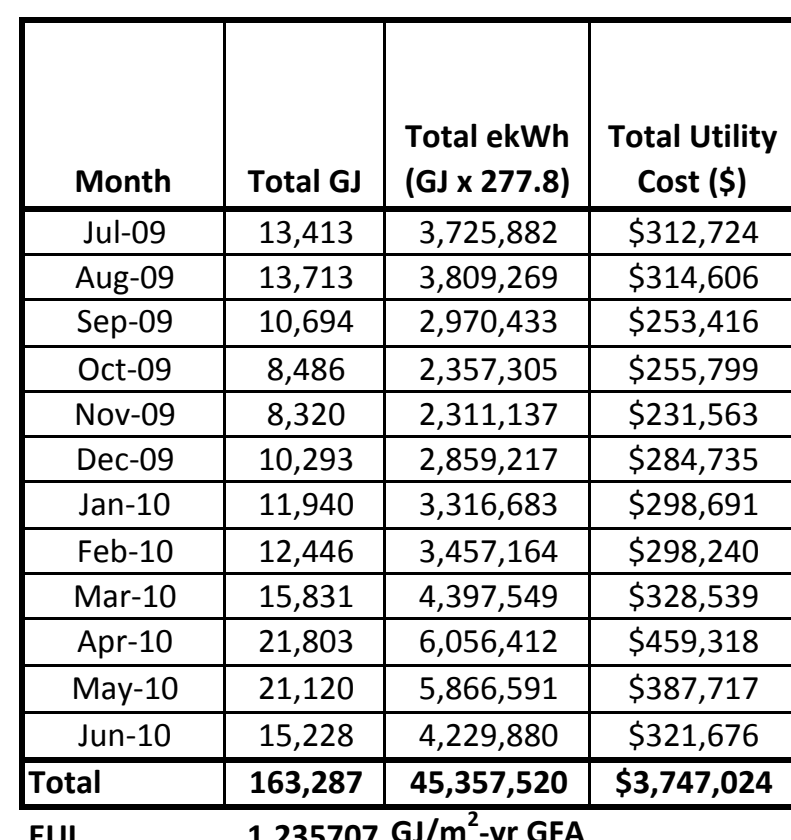

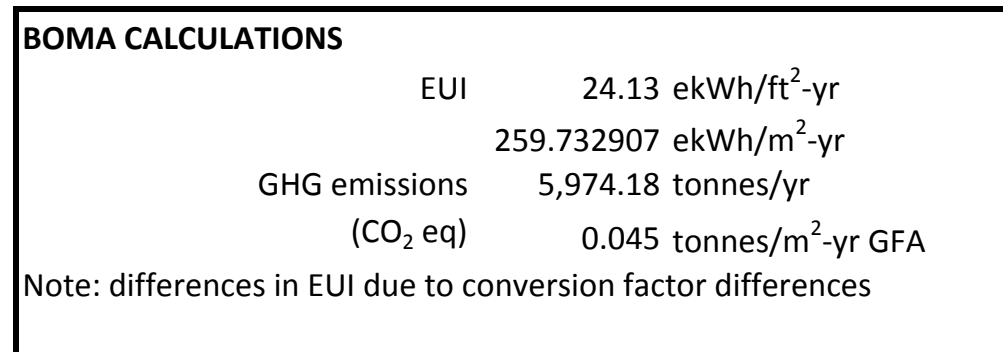

Note: used values determined by BOMA from this point on

\section{Pre-retrofit EUI (BOMA):}

Pre-retrofit GHG emissions (BOMA)

Pre-retrofit cost index (BOMA):

$$
\begin{gathered}
1.2357072 \mathrm{GJ} / \mathrm{m}^{2}-\text { yr GFA } \\
0.045 \text { tonnes } / \mathrm{m}^{2} \text {-yr GFA } \\
\$ 28.36 \$ / \mathrm{m}^{2} \text {-yr GFA }
\end{gathered}
$$$$
\$ 41.33 \$ / \mathrm{m}^{2} \text {-yr office space }
$$

(average)

Retrofit Savings (Toronto Atmospheric Fund Case Study):

\section{Retrofit Savings (Self-Reported by Property Manager):}

31000000 as of $2013-3$ years approximately

$37200 \mathrm{GJ}$ annually

$0.28151836 \mathrm{GJ} / \mathrm{m}^{2}$-yr GFA

$22.8 \%$ reduction

$14 \%$ reduction from 2008 levels in 2011

\section{TAF 2008 levels in early 2013 \\ Post-retrofit EUI: \\ $0.95418888 \mathrm{GJ} / \mathrm{m}^{2}-\mathrm{yr} \mathrm{G}$

National Energy Board, 2014, "Energy Conversion Tables", https://wwww neb-one.gc.ca/nrg/cnvrsntbl/index-eng.htm

2 ENERGY STAR Portfolio Manager, 2014, "Thermal Energy Conversions", https://portfoliomanager.energystar.gov/pdf/reference/Thermal\%20Conversions.pdf
Cost Index
$343.3 \mathrm{ekWh} / \mathrm{m}^{2}$-yr GFA
$\$ 28.36 \$ / \mathrm{m}^{2}-\mathrm{yr}$ GFA
$\$ 41.33 \quad \$ / \mathrm{m}^{2}$-yr office space

\begin{aligned} & \hline $1 \mathrm{GJ}=26.96838095 \mathrm{~m} 3$ natural gas (NRCan, NED ${ }^{2}$ ) \\ & $1 \mathrm{GJ}=277.7777778 \mathrm{ekWh} \\ & \therefore 1 \mathrm{~m}^{3}$ natural gas $\approx 10.30012807 \mathrm{ekWh} \\ & 1$ ton-hr refrigeration $\approx 0.012660672 \mathrm{GJ}\left(\right.$ EnergyStar $\left.{ }^{2}\right) \\ & 1 \mathrm{lb}$ district steam $\approx 0.001259737 \mathrm{GJ}$ (EneryyStar $\left.{ }^{2}\right) \\ &$\hline\end{aligned}

$1 \mathrm{lb}$ district steam $\approx 0.001259737 \mathrm{GJ}\left(\right.$ (Energystar $\left.\mathrm{r}^{2}\right)$
$\$ 27.58 \$ / \mathrm{m} 2-y \mathrm{yr} \mathrm{GFA}$ $2.7 \%$ savings 


\begin{tabular}{|c|c|c|c|c|c|c|}
\hline & $\begin{array}{l}\text { Total Office } \\
\text { Area }\left(\mathrm{m}^{2}\right)\end{array}$ & \begin{tabular}{|c} 
Direct \\
Asking Rate \\
$\$ / \mathrm{m}^{2}$
\end{tabular} & $\begin{array}{c}\text { Total } \\
\text { Additional } \\
\text { Rent }\left(\$ / \mathbf{m}^{2}\right)\end{array}$ & $\begin{array}{c}\text { Total } \\
\text { Estimated } \\
\text { Direct Rent } \\
\left(\$ / \mathrm{m}^{2}\right)\end{array}$ & $\begin{array}{c}\text { Total } \\
\text { Available } \\
\text { Area }\left(\mathrm{m}^{2}\right)\end{array}$ & $\begin{array}{c}\text { Total } \\
\text { Available } \\
\text { Rate (\%) }\end{array}$ \\
\hline Q3 2014 & 123,491 & & & & & \\
\hline Q2 2014 & 123,491 & nd & $\$ 333.68$ & nd & 5,948 & 4.8 \\
\hline Q1 2014 & 123,491 & nd & \begin{tabular}{|l|}
$\$ 33.68$ \\
\end{tabular} & nd & 6,602 & 5.3 \\
\hline Q4 2013 & 123,491 & $\$ 333.68$ & \begin{tabular}{|l|l}
$\$ 333.68$ \\
\end{tabular} & $\$ 667.36$ & 4,676 & 3.8 \\
\hline Q3 2013 & 123,491 & nd & \begin{tabular}{|l|}
$\$ 331.53$ \\
\end{tabular} & nd & 4,787 & 3.9 \\
\hline Q2 2013 & 123,491 & nd & \begin{tabular}{|l|}
$\$ 331.53$ \\
\end{tabular} & nd & 4,787 & 3.9 \\
\hline Q1 2013 & 123,491 & nd & \begin{tabular}{|l|}
$\$ 331.53$ \\
\end{tabular} & nd & 4,787 & 3.9 \\
\hline Q4 2012 & 123,491 & $\$ 333.68$ & \begin{tabular}{|l|l}
$\$ 331.53$ \\
\end{tabular} & $\$ 665.21$ & 8,169 & 6.6 \\
\hline Q3 2012 & 123,491 & nd & $\begin{array}{|ll|}\$ & 331.53 \\
\end{array}$ & nd & 7,094 & 5.7 \\
\hline Q2 2012 & 123,491 & nd & \begin{tabular}{|l|l|}
$\$$ & 336.91 \\
\end{tabular} & nd & 6,331 & 5.1 \\
\hline Q1 2012 & 123,491 & nd & \begin{tabular}{|l|}
$\$ 336.91$ \\
\end{tabular} & nd & 7,925 & 6.4 \\
\hline Q4 2011 & 123,491 & nd & \begin{tabular}{|l|l|}
$\$ 336.91$ \\
\end{tabular} & nd & 11,365 & 9.2 \\
\hline Q3 2011 & 123,491 & nd & \begin{tabular}{|l|}
$\$ 336.91$ \\
\end{tabular} & nd & 10,712 & 8.7 \\
\hline Q2 2011 & 123,491 & nd & \begin{tabular}{|l|}
$\$ 336.91$ \\
\end{tabular} & nd & 11,702 & 9.5 \\
\hline Q1 2011 & 123,491 & nd & \$ 336.91 & nd & 11,852 & 9.6 \\
\hline Q4 2010 & 123,491 & nd & \begin{tabular}{|l|l|}
$\$ 336.91$ \\
\end{tabular} & nd & 16,583 & 13.4 \\
\hline Q3 2010 & 123,491 & nd & \begin{tabular}{|l|}
$\$ 336.91$ \\
\end{tabular} & nd & 18,511 & 15 \\
\hline Q2 2010 & 123,491 & nd & \begin{tabular}{|l|}
$\$ 336.91$ \\
\end{tabular} & nd & 16,789 & 13.6 \\
\hline Q1 2010 & 123,491 & nd & \begin{tabular}{|l|l|}
$\$$ & 336.91 \\
\end{tabular} & nd & 20,339 & 16.5 \\
\hline Q42009 & 123,491 & nd & $\$ 336.91$ & nd & 18,618 & 15.1 \\
\hline Q32009 & 123,491 & $\$ 333.68$ & $\$ 339.06$ & $\$ 672.74$ & 18,618 & 15.1 \\
\hline Q2 2009 & 123,491 & $\$ 333.68$ & \begin{tabular}{|l|}
$\$ 339.06$ \\
\end{tabular} & $\$ 672.74$ & 18,618 & 15.1 \\
\hline Q1 2009 & 123,491 & $\$ 333.68$ & $\begin{array}{ll}\$ 339.06 \\
\end{array}$ & $\$ 672.74$ & 18,618 & 15.1 \\
\hline Q4 2008 & 123,491 & $\$ 333.68$ & \begin{tabular}{|l|l}
$\$ 339.06$ \\
\end{tabular} & $\$ 672.74$ & 18,618 & 15.1 \\
\hline Q3 2008 & 123,491 & $\$ 333.68$ & \begin{tabular}{|l|l|}
$\$ 342.51$ \\
\end{tabular} & $\$ 676.19$ & 18,618 & 15.1 \\
\hline Q2 2008 & 123,491 & $\$ 333.68$ & \begin{tabular}{|l|l|}
$\$ 342.51$ \\
\end{tabular} & $\$ 676.19$ & 19,277 & 15.6 \\
\hline Q1 2008 & 123,491 & $\$ 333.68$ & \begin{tabular}{|l|}
$\$ 342.51$ \\
\end{tabular} & $\$ 676.19$ & 19,126 & 15.5 \\
\hline Q4 2007 & 123,491 & $\$ 333.68$ & \begin{tabular}{|l|l}
$\$ 3$ & 33.76
\end{tabular} & $\$ 668.44$ & 4,809 & 3.9 \\
\hline Q3 2007 & 123,491 & $\$ 333.68$ & \begin{tabular}{|l|}
$\$ 334.76$ \\
\end{tabular} & $\$ 668.44$ & 4,212 & 3.4 \\
\hline Q2 2007 & 123,491 & $\$ 333.68$ & \begin{tabular}{|l|}
$\$ 332.50$ \\
\end{tabular} & $\$ 666.18$ & 2,044 & 1.7 \\
\hline Q1 2007 & 123,491 & $\$ 333.68$ & \begin{tabular}{|l|}
$\$ 332.50$ \\
\end{tabular} & $\$ 666.18$ & 2,044 & 1.7 \\
\hline Q4 2006 & 123,491 & $\$ 333.68$ & \begin{tabular}{|l|}
$\$ 332.50$ \\
\end{tabular} & $\$ 666.18$ & 3,009 & 2.4 \\
\hline Q3 2006 & 123,491 & $\$ 333.68$ & \begin{tabular}{|l|}
$\$ 332.50$ \\
\end{tabular} & $\$ 666.18$ & 3,009 & 2.4 \\
\hline Q2 2006 & 123,491 & $\$ 322.92$ & \begin{tabular}{ll|}
$\$ 332.50$ \\
\end{tabular} & $\$ 655.41$ & 3,350 & 2.7 \\
\hline Q1 2006 & 123,491 & $\$ 301.39$ & 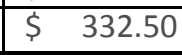 & $\$ 633.89$ & 3,290 & 2.7 \\
\hline Q4 2005 & 123,491 & $\$ 301.39$ & \begin{tabular}{|l|}
$\$ 332.50$ \\
\end{tabular} & $\$ 633.89$ & 2,888 & 2.3 \\
\hline Q3 2005 & 123,491 & $\$ 301.39$ & \begin{tabular}{|l|}
$\$ 328.51$ \\
\end{tabular} & $\$ 629.90$ & 2,888 & 2.3 \\
\hline Q2 2005 & 123,491 & $\$ 290.63$ & $\$ 328.51$ & $\$ 619.14$ & 5,585 & 4.5 \\
\hline Q1 2005 & 123,491 & $\$ 290.63$ & \begin{tabular}{|ll}
$\$ 328.51$ \\
\end{tabular} & $\$ 619.14$ & 6,496 & 5.3 \\
\hline
\end{tabular}

\begin{tabular}{|c|c|c|c|c|c|c|c|c|}
\hline & $\begin{array}{c}\text { Direct } \\
\text { Asking Rate } \\
\$ / \mathrm{m}^{2}\end{array}$ & $\begin{array}{c}\text { Total } \\
\text { Additional } \\
\text { Rent }\left(\$ / \mathrm{m}^{2}\right)\end{array}$ & $\begin{array}{c}\text { Total } \\
\text { Estimated } \\
\text { Direct Rent } \\
\left(\$ / \mathrm{m}^{2}\right)\end{array}$ & $\begin{array}{c}\text { Total } \\
\text { Available } \\
\text { Area }\left(\mathrm{m}^{2}\right)\end{array}$ & $\begin{array}{c}\text { Total } \\
\text { Available } \\
\text { Rate (\%) }\end{array}$ & $\begin{array}{c}\text { Occupancy } \\
\text { Rate }\end{array}$ & \begin{tabular}{|c} 
Effective Total \\
Additional Rent \\
$\left(\$ / \mathrm{m}^{2}\right)$
\end{tabular} & $\begin{array}{c}\text { Errective } \\
\text { Total } \\
\text { Estimated } \\
\text { Direct Rent } \\
\left(\$ / \mathrm{m}^{2}\right) \\
\end{array}$ \\
\hline 2014 & nd & $\$ 333.68$ & nd & 5,948 & $4.8 \%$ & $95.2 \%$ & $\$ 317.61$ & nd \\
\hline 2013 & $\$ 333.68$ & $\$ 333.68$ & $\$ 667.36$ & 4,676 & $3.8 \%$ & $96.2 \%$ & $\$ 321.05$ & $\$ 642.09$ \\
\hline 2012 & $\$ 333.68$ & $\$ 331.53$ & $\$ 665.21$ & 8,169 & $6.6 \%$ & $93.4 \%$ & $\$ 309.60$ & $\$ 621.21$ \\
\hline 2011 & nd & $\$ 336.91$ & nd & 11,365 & $9.2 \%$ & $90.8 \%$ & $\$ 305.90$ & nd \\
\hline 2010 & nd & $\$ 336.91$ & nd & 16,583 & $13.4 \%$ & $86.6 \%$ & $\$ 291.67$ & nd \\
\hline 2009 & $\$ 333.68$ & $\$ 336.91$ & $\$ 672.74$ & 18,618 & $15.1 \%$ & $84.9 \%$ & $\$ 286.12$ & $\$ 571.32$ \\
\hline 2008 & $\$ 333.68$ & $\$ 339.06$ & $\$ 672.74$ & 18,618 & $15.1 \%$ & $84.9 \%$ & $\$ 287.95$ & $\$ 571.32$ \\
\hline 2007 & $\$ 333.68$ & $\$ 334.76$ & $\$ 668.44$ & 4,809 & $3.9 \%$ & $96.1 \%$ & $\$ 321.72$ & $\$ 642.41$ \\
\hline 2006 & $\$ 333.68$ & $\$ 332.50$ & $\$ 666.18$ & 3,009 & $2.4 \%$ & $97.6 \%$ & $\$ 324.40$ & $\$ 649.95$ \\
\hline 2005 & $\$ 301.39$ & $\$ 332.50$ & $\$ 633.89$ & 2,888 & $2.3 \%$ & $97.7 \%$ & $\$ 324.72$ & $\$ 619.06$ \\
\hline
\end{tabular}

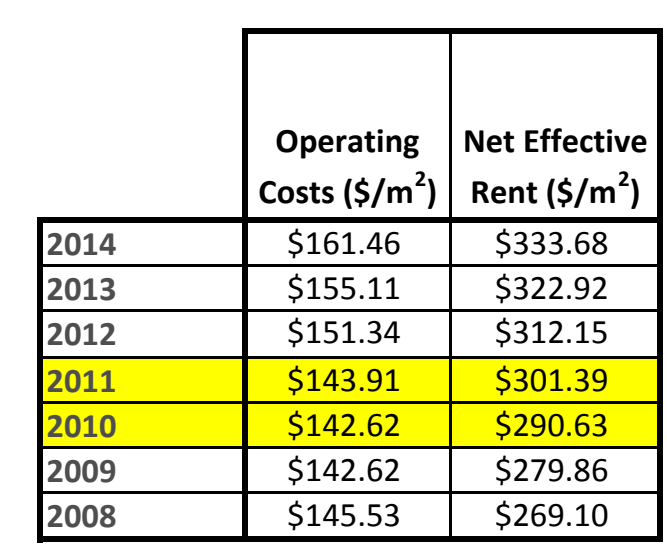

$$
{ }^{*} \text { Q4 data except } 2014 \text { is Q2 data } 2009 \text { rent is Q1-Q3 data (constant rent assumed through the year) }
$$

Direct Asking Rate $=$ net rental rate (excludes $0 \& M$ costs and taxes)

Additional Rent $=0 \& M$ costs and taxes

BUILDING C FINANCIAL CALCULATIONS

$10.7639 \mathrm{ft}^{2}=1 \mathrm{~m}^{2}$

\begin{tabular}{|l|c|c|}
\cline { 2 - 3 } \multicolumn{1}{c|}{} & $\begin{array}{c}\text { \% Add. } \\
\text { Rent }\end{array}$ & $\begin{array}{c}\text { \% Op. Costs of } \\
\text { Total Add. Rent }\end{array}$ \\
\hline 2014 & nd & $48.4 \%$ \\
\hline 2013 & $50.0 \%$ & $46.5 \%$ \\
\hline 2012 & $49.8 \%$ & $45.6 \%$ \\
\hline 2011 & nd & $42.7 \%$ \\
\hline 2010 & nd & $42.3 \%$ \\
\hline 2009 & $50.1 \%$ & $42.3 \%$ \\
\hline 2008 & $50.4 \%$ & $42.9 \%$ \\
\hline 2007 & $50.1 \%$ & nd \\
\hline 2006 & $49.9 \%$ & nd \\
\hline 2005 & $52.5 \%$ & nd \\
\hline MIN & $49.8 \%$ & $42.3 \%$ \\
\hline MAX & $52.5 \%$ & $48.4 \%$ \\
\hline AVG & $50.4 \%$ & $44.4 \%$ \\
\hline
\end{tabular}

$\%$ Add. Rent $\quad=$ percentage of Total Estimated Direct Rent attributed to Total Additional Rent (O\&M costs and taxes) $=$ Total Additional Rent $\div$ Total Estimated Direct Rent

\% Additional Rent ranges between $49.8 \%$ and $52.5 \%$ of Total Estimated Direct Rent (average 50.4\%).

$\%$ Op. Costs of Total Add. Rent

$=$ percentage of Total Additional Rent (O\&M costs and taxes) attributed to Operating Costs

Op. Costs of Total Add. Rent ranges between $42.3 \%$ and $48.4 \%$ of Total Estimated Direct Rent (average $44.4 \%$ ) and is on the rise post-retrofit because of large increases in utility costs.

Conclusion: acceptable to assume operating costs follow roughly the same trends as total additional rent. 


\begin{tabular}{|c|c|c|c|c|c|c|c|c|c|c|c|}
\hline Month & \begin{tabular}{|c} 
Natural \\
Gas \\
$\left(\mathrm{m}^{3}\right)$ \\
\end{tabular} & $\begin{array}{l}\text { Natural } \\
\text { Gas (\$) }\end{array}$ & $\begin{array}{c}\text { Electricity } \\
\text { (kWh) }\end{array}$ & $\begin{array}{c}\text { Electricity } \\
(\mathrm{kW})\end{array}$ & $\begin{array}{c}\text { Electricity } \\
\text { (kVA) }\end{array}$ & Electricity (\$) & Steam (Ibs) & Steam (\$) & $\begin{array}{c}\text { CHW (ton } \\
\text { hours) }\end{array}$ & CHW (\$) & $\begin{array}{l}\text { Power } \\
\text { Factor }\end{array}$ \\
\hline Jul-09 & 0 & $\$ 0$ & $3,312,990$ & 6,160 & 7,066 & $\$ 274,218$ & $6,063,912$ & $\$ 157,637$ & $1,070,400$ & $\$ 158,329$ & $88.20 \%$ \\
\hline Aug-09 & 0 & $\$ 0$ & $3,258,894$ & 6,197 & 7,029 & $\$ 323,677$ & 0 & $\$ 53,125$ & $1,173,300$ & $\$ 175,708$ & $88.60 \%$ \\
\hline Sep-09 & 0 & $\$ 0$ & $3,242,934$ & 6,075 & 6,860 & $\$ 271,618$ & 0 & $\$ 53,125$ & 872,500 & $\$ 144,021$ & $87.50 \%$ \\
\hline Oct-09 & 0 & $\$ 0$ & $3,227,722$ & 6,347 & 7,253 & $\$ 325,300$ & 0 & $\$ 53,125$ & 332,400 & $\$ 82,116$ & $87.10 \%$ \\
\hline Nov-09 & 0 & $\$ 0$ & $3,133,838$ & 5,885 & 53 & $\$ 277,748$ & 57,508 & $\$ 53,125$ & 234,000 & $\$ 67,572$ & $88.70 \%$ \\
\hline Dec-09 & 0 & $\$ 0$ & $3,217,665$ & 6,438 & 7,255 & $\$ 330,726$ & 565,589 & $\$ 61,966$ & 125,100 & $\$ 53,912$ & $90.40 \%$ \\
\hline Jan-10 & 0 & $\$ 0$ & $3,379,071$ & 6,617 & 7,316 & $\$ 324,718$ & $4,120,320$ & $\$ 123,818$ & 168,700 & $\$ 61,675$ & $88.80 \%$ \\
\hline Feb-10 & 0 & $\$ 0$ & $2,951,179$ & 5,832 & 6,564 & $\$ 288,596$ & $5,813,436$ & $\$ 153,278$ & 125,400 & $\$ 57,726$ & $86 \%$ \\
\hline Mar-10 & 0 & $\$ 0$ & $3,216,162$ & 6,069 & 7,088 & $\$ 267,770$ & $9,264,006$ & $\$ 213,318$ & 238,800 & $\$ 68,268$ & $87.30 \%$ \\
\hline Apr-10 & 0 & $\$ 0$ & $2,994,051$ & 5,923 & 6,786 & $\$ 319,049$ & $12,216,760$ & $\$ 262,743$ & 430,000 & $\$ 96,836$ & $87.90 \%$ \\
\hline May-10 & 0 & $\$ 0$ & $3,050,264$ & 6,295 & 7,159 & $\$ 320,199$ & \begin{tabular}{|l}
$17,052,128$ \\
\end{tabular} & $\$ 387,371$ & 745,100 & $\$ 139,706$ & $87.50 \%$ \\
\hline Jun-10 & 0 & $\$ 0$ & $2,959,708$ & 6,059 & 28 & $\$ 275,676$ & 13,11 & $\$ 227,787$ & 816,100 & $\$ 144,414$ & \\
\hline Total & 0 & 0 & $37,944,478$ & 73,897 & 84,057 & $\$ 3,599,295$ & $68,266,920$ & $\$ 1,800,418$ & $6,331,800$ & $\$ 1,250,283$ & 87.9 \\
\hline
\end{tabular}

ENERGY CALCULATIONS (BOMA)

\begin{tabular}{|c|r|r|r|}
\hline Month & Total GJ & $\begin{array}{r}\text { Total ekWh } \\
\text { (GJ x 277.8) }\end{array}$ & $\begin{array}{c}\text { Total Utility } \\
\text { Cost (\$) }\end{array}$ \\
\hline Jul-09 & 33118 & $9,199,356$ & $\$ 590,184$ \\
Aug-09 & 26587 & $7,385,218$ & $\$ 552,510$ \\
Sep-09 & 22721 & $6,311,388$ & $\$ 468,764$ \\
Oct-09 & 15828 & $4,396,724$ & $\$ 460,541$ \\
Nov-09 & 14317 & $3,976,905$ & $\$ 398,445$ \\
Dec-09 & 13880 & $3,855,538$ & $\$ 446,604$ \\
Jan-10 & 19491 & $5,414,175$ & $\$ 510,211$ \\
Feb-10 & 19535 & $5,426,470$ & $\$ 499,600$ \\
Mar-10 & 26272 & $7,297,711$ & $\$ 549,356$ \\
Apr-10 & 31613 & $8,781,271$ & $\$ 678,628$ \\
May-10 & 41896 & $11,637,670$ & $\$ 847,276$ \\
Jun-10 & 37507 & $10,418,495$ & $\$ 647,877$ \\
\hline Total & $\mathbf{3 0 2 7 6 3}$ & $\mathbf{8 4 , 1 0 0 , 9 2 1}$ & $\mathbf{\$ 6 , 6 4 9 , 9 9 6}$ \\
\hline
\end{tabular}

EUI $\quad 1.597896 \mathrm{GJ} / \mathrm{m}^{2}$-yr GFA

Cost Index

$443.9 \mathrm{ekWh} / \mathrm{m}^{2}$-yr GFA

$\$ 35.10 \$ / \mathrm{m}^{2}$-yr GFA

$\$ 53.85 \$ / \mathrm{m}^{2}$-yr office space

\section{GHG emissions $332.066315 \mathrm{ekWh} / \mathrm{m}^{2}-\mathrm{yr}$ \\ $\left(\mathrm{CO}_{2}\right.$ eq) $\quad 11,762.79$ tonnes $/ \mathrm{yr}$ \\ BOMA CALCULATIONS$$
\begin{aligned}
& 0.062 \text { tonnes } / \mathrm{m}^{2}-\mathrm{yr} \text { GFA } \\
& 0.79 \text {. }
\end{aligned}
$$

Note: differences in EUI due to conversion factor differences

\begin{tabular}{|lcl|}
\hline GFA: & $2,039,503$ & $\mathrm{ft}^{2}$ \\
(BOMA) & 189,476 & $\mathrm{~m}^{2}$ \\
\hline
\end{tabular}

Note: used values determined by BOMA from this point on

\section{Pre-retrofit EUI (BOMA):}

Pre-retrofit cost index (BOMA):

$$
\begin{gathered}
1.5978962 \mathrm{GJ} / \mathrm{m}^{2} \text {-yr GFA } \\
0.062 \text { tonnes } / \mathrm{m}^{2} \text {-yr GFA } \\
\$ \quad 35.10 \$ / \mathrm{m}^{2} \text {-yr GFA }
\end{gathered}
$$$$
\$ 53.85 \$ / \mathrm{m}^{2} \text {-yr office space }
$$

Pre-retrofit GHG emissions (BOMA)

\section{$(2009 / 2010)$}

(CO2 eq)

$4 \%$ reduction from 2008 levels in 2011

$18 \%$ reduction from 2008 levels in early 2013
Cost Savings (BOMA): $\$ 352,600$ annually $5.3 \%$ savings
Post-retrofit cost index: $\quad \$ 33.24 \$ / \mathrm{m}^{2}$-yr GFA

Retrofit Savings (Self-Reported by Property Manager): most recent accurate estimate

\section{Post-retrofit EUI:} $1.31027488 \mathrm{GJ} / \mathrm{m}^{2}-\mathrm{yr} \mathrm{GFA}$

1 Natural Resources Canada, 2014, "Natural Gas: A Primer", http://www.nrcan.gc.ca/energy/natural-gas/5641

National Energy Board, 2014, "Energy Conversion Tables", https://www.neb-one.gc.ca/nrg/cnvrsntbl/index-eng.html

2 ENERGY STAR Portfolio Manager, 2014, "Thermal Energy Conversions", https://portfoliomanager.energystar.gov/pdf/reference/Thermal\%20Conversions.pdf 
BUILDING D DATA (nd = "no data")

ALTUS INSITE RAW DATA

\begin{tabular}{|c|c|c|c|c|c|c|c|c|c|}
\hline & $\begin{array}{l}\text { Total Office } \\
\text { Area }\left(\mathrm{m}^{2}\right)\end{array}$ & \begin{tabular}{|c} 
Direct \\
Asking Rate \\
$\$ / \mathrm{m}^{2}$
\end{tabular} & $\begin{array}{c}\text { Total } \\
\text { Additional } \\
\text { Rent }\left(\$ / \mathrm{m}^{2}\right)\end{array}$ & $\begin{array}{c}\text { Total } \\
\text { Estimated } \\
\text { Direct Rent } \\
\left(\$ / \mathrm{m}^{2}\right)\end{array}$ & $\begin{array}{c}\text { Total } \\
\text { Available } \\
\text { Area }\left(\mathrm{m}^{2}\right)\end{array}$ & $\begin{array}{c}\text { Total } \\
\text { Available } \\
\text { Rate (\%) }\end{array}$ & & $\begin{array}{c}\text { Office } \\
\text { Standard } \\
\left(\mathrm{O \& M} / \mathrm{m}^{2}\right)\end{array}$ & $\begin{array}{l}\text { Occupancy } \\
\text { Rate }\end{array}$ \\
\hline Q32014 & 38,274 & nd & $\$ 234.65$ & nd & 2,622 & 6.9 & 2014 & $\$ 129.70$ & $98.7 \%$ \\
\hline Q2 2014 & 38,274 & nd & $\$ 234.65$ & nd & 5,163 & 13.5 & 2013 & $\$ 130.89$ & $99.7 \%$ \\
\hline Q1 2014 & 38,274 & nd & $\$ 234.65$ & nd & 4,997 & 13.1 & 2012 & \$124.97 & $97.7 \%$ \\
\hline \begin{tabular}{|l|} 
Q42013 \\
\end{tabular} & 38,274 & nd & $\$ 232.72$ & nd & 6,642 & 17.4 & 2011 & $\$ 131.75$ & $97.2 \%$ \\
\hline Q3 2013 & 38,274 & nd & $\$ 232.72$ & nd & 1,234 & 3.2 & 2010 & $\$ 118.40$ & $97.7 \%$ \\
\hline Q2 2013 & 38,274 & nd & $\$ 232.72$ & nd & 2,185 & 5.7 & 2009 & $\$ 112.91$ & $98.9 \%$ \\
\hline Q1 2013 & 38,274 & nd & $\$ 232.72$ & nd & 1,488 & 3.9 & 2008 & nd & nd \\
\hline Q4 2012 & 38,274 & nd & $\$ 229.59$ & nd & 2,524 & 6.6 & 2007 & nd & nd \\
\hline Q3 2012 & 38,274 & nd & $\$ 229.59$ & nd & 3,068 & 8 & 2006 & nd & nd \\
\hline Q2 2012 & 38,274 & nd & $\$ 229.59$ & nd & 2,996 & 7.8 & 2005 & nd & nd \\
\hline Q1 2012 & 38,274 & nd & $\$ 229.59$ & nd & 3,424 & 8.9 & * op & ta back to & only \\
\hline
\end{tabular}

\begin{tabular}{|l|l|l|l|l|l|l|}
\hline Q3 2011 & 38,274 & nd & $\$ 227.98$ & nd & 3,379 & 8.8 \\
\hline Q2 2011 & 38,274 & nd & $\$ 227.98$ & nd & 2,478 & 6.5 \\
\hline
\end{tabular}

Q2 2011

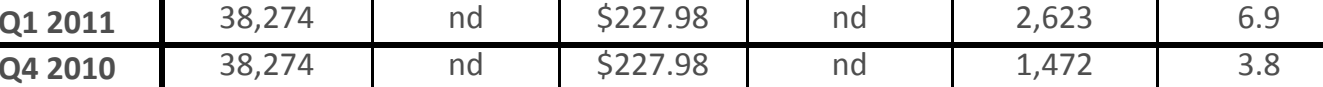

\begin{tabular}{|l|l|l|l|l|l|l|}
\hline Q3 2010 & 38,274 & nd & $\$ 225.72$ & nd & 2,152 & 5.6 \\
\hline
\end{tabular}

Q22010

Q12010

\begin{tabular}{|l|c|c|c|c|c|c|}
\hline Q4 2009 & 38,274 & nd & $\$ 217.32$ & nd & 968 & 2.5 \\
\hline
\end{tabular}

\begin{tabular}{|l|l|l|l|l|l|l|}
\hline Q3 2009 & 38,274 & nd & $\$ 217.32$ & nd & 968 & 2.5 \\
\hline
\end{tabular}

\begin{tabular}{|l|l|l|l}
\hline Q2 2009 & \\
\hline Q1 2009 & 3 & 3 \\
\hline
\end{tabular}

Q12009

\begin{tabular}{|l|l|l|l}
\hline Q4 2008 & 3 \\
\hline 032008 & 3 \\
\hline 022008 & 38 &
\end{tabular}

\begin{tabular}{|l|l|l|l|l|l|}
\hline 38,274 & nd & $\$ 217.32$ & nd & 1,200 & 3.1 \\
\hline 38,274 & nd & $\$ 217.32$ & nd & 1,155 & 3 \\
\hline 38,274 & nd & $\$ 217.32$ & nd & 1,155 & 3 \\
\hline
\end{tabular}

\begin{tabular}{|l|l|l|l|l|l|}
\hline $\mathbf{Q} 2008$ & 38,274 & $\$ 285.24$ & $\$ 208.93$ & $\$ 494.17$ & 879 \\
\hline 2285.24 & $\$ 208.93$ & $\$ 494.17$ & 78 \\
\hline 2
\end{tabular}

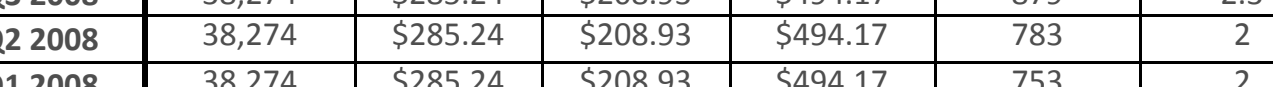

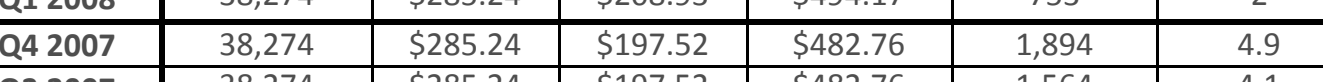

\begin{tabular}{|l|l|l|l|l|l|l|}
\hline $\mathbf{Q 4 2 0 0 7}$ & 38,274 & $\$ 285.24$ & $\$ 197.52$ & $\$ 482.76$ & 1,894 & 4.9 \\
\hline $\mathbf{Q 2 2 0 0 7}$ & 38,274 & $\$ 285.24$ & $\$ 197.52$ & $\$ 482.76$ & 1,564 & 4.1 \\
\hline
\end{tabular}

\begin{tabular}{|l|l|l|l|l|l|l|}
\hline Q2 2007 & 38,274 & $\$ 231.42$ & $\$ 197.52$ & $\$ 428.94$ & 4,170 & 10.9 \\
\hline Q1 2007 & 38,274 & $\$ 220.66$ & $\$ 197.52$ & $\$ 418.18$ & 3,013 & 7.9 \\
\hline
\end{tabular}

\begin{tabular}{|l|l|l|l|l|l|l|}
\hline Q4 2006 & 38,274 & $\$ 220.66$ & $\$ 192.78$ & $\$ 413.44$ & 4,938 & 12.9 \\
\hline Q3 2006 & 38,274 & $\$ 220.66$ & $\$ 192.78$ & $\$ 413.44$ & 3,940 & 10.3 \\
\hline
\end{tabular}

Q2 2006

\begin{tabular}{|l|l|l|l|l|l|}
\hline 38,274 & $\$ 182.99$ & $\$ 192.78$ & $\$ 375.77$ & 1,017 & 2.7 \\
\hline 38,274 & $\$ 182.99$ & $\$ 192.78$ & $\$ 375.77$ & 2,710 & 7.1 \\
\hline
\end{tabular}

\begin{tabular}{|l|l|l|l|l|l|l|}
\hline $\mathbf{Q} 2005$ & 38,274 & $\$ 182.99$ & $\$ 194.50$ & $\$ 377.49$ & 5,299 & 13.8 \\
\hline $\mathbf{3 3 2 0 0 5}$ & 38,274 & $\$ 182.99$ & $\$ 194.50$ & $\$ 377.49$ & 5,520 & 14.4 \\
\hline
\end{tabular}

\begin{tabular}{|l|l|l|l|l|l|l|}
\hline $\mathbf{Q} 2005$ & 38,274 & $\$ 182.99$ & $\$ 194.50$ & $\$ 377.49$ & 5,520 & 14.4 \\
\hline $\mathbf{Q} 2005$ & 38,274 & $\$ 182.99$ & $\$ 194.50$ & $\$ 377.49$ & 7,957 & 20.8 \\
\hline
\end{tabular}

\begin{tabular}{l|l|l|l|l|l|l}
\hline Q1 2005 & 38,274 & $\$ 182.99$ & $\$ 194.50$ & $\$ 377.49$ & 7,797 & 20.4
\end{tabular}

* 2014 Altus Insite Data included only the first three quarters
BUILDING D FINANCIAL CALCULATIONS

BUIDING OPERATOR RAW DATA

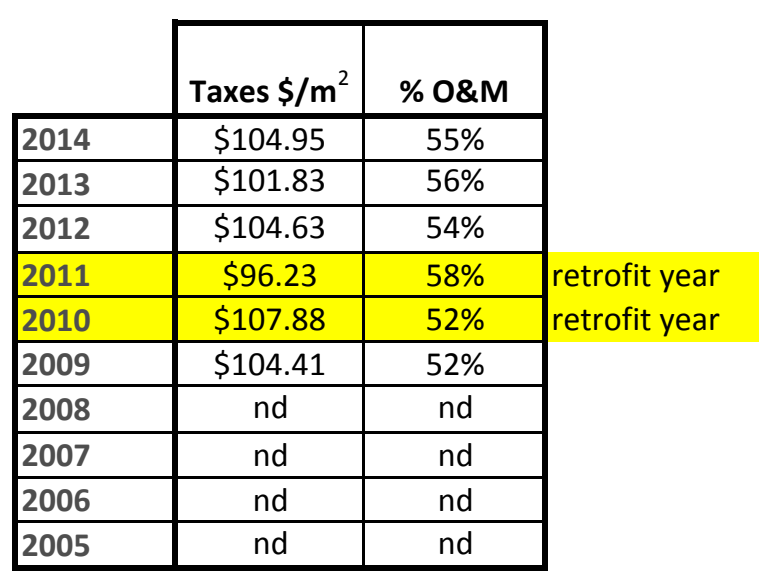

OCCUPANCY RATE COMPARISON

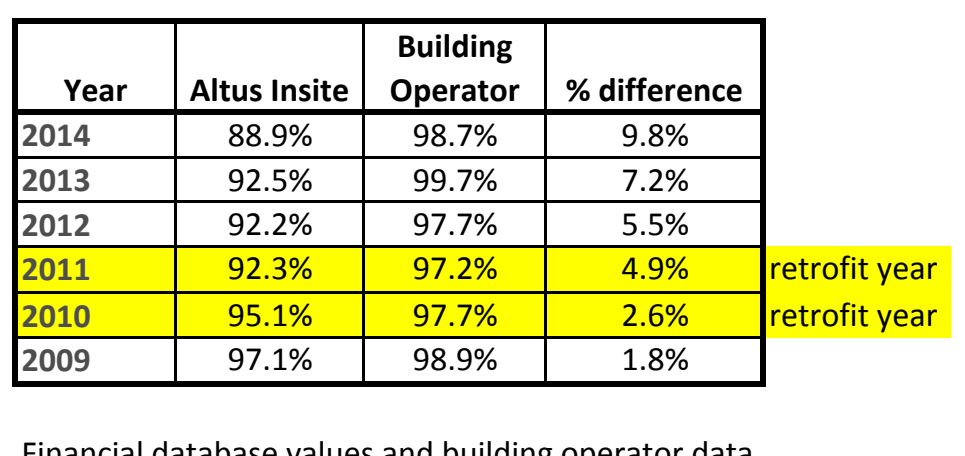

Financial database values and building operator data for occupancy rate had up to a $10 \%$ difference.
ALtUS INSITE ANNUAL AVERAGE DATA

\begin{tabular}{|c|c|c|c|c|c|c|c|c|}
\hline & \begin{tabular}{|c|} 
Direct \\
Asking Rate \\
$\$ / \mathrm{m}^{2}$
\end{tabular} & $\begin{array}{c}\text { Total } \\
\text { Additional } \\
\text { Rent }\left(\$ / \mathrm{m}^{2}\right)\end{array}$ & $\begin{array}{c}\text { Total } \\
\text { Estimated } \\
\text { Direct Rent } \\
\left(\$ / \mathrm{m}^{2}\right)\end{array}$ & $\begin{array}{c}\text { Total } \\
\text { Available } \\
\text { Area }\left(\mathrm{m}^{2}\right)\end{array}$ & $\begin{array}{c}\text { Total } \\
\text { Available } \\
\text { Rate (\%) }\end{array}$ & $\begin{array}{c}\text { Occupancy } \\
\text { Rate }\end{array}$ & $\begin{array}{c}\text { Effective Total } \\
\text { Additional Rent } \\
\left(\$ / \mathrm{m}^{2}\right)\end{array}$ & $\begin{array}{l}\text { Effective Total } \\
\text { Estimated Direct } \\
\text { Rent }\left(\$ / \mathrm{m}^{2}\right)\end{array}$ \\
\hline 2014 & nd & $\$ 234.65$ & nd & 4,261 & $11.1 \%$ & $88.9 \%$ & $\$ 208.53$ & nd \\
\hline 2013 & nd & $\$ 232.72$ & nd & 2,887 & $7.5 \%$ & $92.5 \%$ & $\$ 215.16$ & nd \\
\hline 2012 & nd & $\$ 229.59$ & nd & 3,003 & $7.8 \%$ & $92.2 \%$ & $\$ 211.58$ & nd \\
\hline 2011 & nd & $\$ 227.98$ & nd & 2,965 & $7.7 \%$ & $92.3 \%$ & $\$ 210.32$ & nd \\
\hline 2010 & nd & $\$ 226.28$ & nd & 1,873 & $4.9 \%$ & $95.1 \%$ & $\$ 215.21$ & nd \\
\hline 2009 & nd & $\$ 217.32$ & nd & 1,120 & $2.9 \%$ & $97.1 \%$ & $\$ 210.97$ & nd \\
\hline 2008 & $\$ 285.24$ & $\$ 208.93$ & $\$ 494.17$ & 1,076 & $2.8 \%$ & $97.2 \%$ & $\$ 203.05$ & $\$ 480.27$ \\
\hline 2007 & $\$ 255.64$ & $\$ 197.52$ & $\$ 453.16$ & 2,660 & $7.0 \%$ & $93.0 \%$ & $\$ 183.79$ & $\$ 421.66$ \\
\hline 2006 & $\$ 201.82$ & $\$ 192.78$ & $\$ 394.60$ & 3,151 & $8.2 \%$ & $91.8 \%$ & $\$ 176.91$ & $\$ 362.11$ \\
\hline 2005 & $\$ 182.99$ & $\$ 194.50$ & $\$ 377.49$ & 6,643 & $17.4 \%$ & $82.6 \%$ & $\$ 160.74$ & $\$ 311.97$ \\
\hline
\end{tabular}

retrofit year taxes $=$ total additional rent - office standard $0 \& M$

$\% 0 \& \mathrm{M}=\frac{\text { office standard } 0 \& \mathrm{M}}{\text { tota }}$

O\&M costs typically made up between 52\% and 58\% of "total additional rent" (average of 55\%).

Direct Asking Rate $=$ net rental rate (excludes O\&M costs and taxes) Additional Rent $=0 \& M$ costs and taxes

$10.7639 \mathrm{ft}^{2}=1 \mathrm{~m}^{2}$ 


\section{ENERGY DATA (BOMA)}

\begin{tabular}{|c|c|c|c|c|c|}
\hline Month & $\begin{array}{l}\text { Natural } \\
\text { Gas }\left(\mathrm{m}^{3}\right)\end{array}$ & $\begin{array}{l}\text { Natural Gas } \\
\text { (\$) }\end{array}$ & $\begin{array}{l}\text { Electricity } \\
\text { (kWh) }\end{array}$ & Electricity (\$) & $\begin{array}{c}\text { Natural } \\
\text { Gas \% of } \\
\text { Total } \\
\text { Utility } \\
\text { Cost }\end{array}$ \\
\hline $\begin{array}{l}\text { Sep-10 } \\
\text { s. }\end{array}$ & 2,567 & $\$ 854.51$ & $1,311,300$ & $\$ 120,825.04$ & $0.7 \%$ \\
\hline Oct-10 & 6,946 & $\$ 1,820.28$ & $1,191,413$ & $\$ 124,077.07$ & $1.4 \%$ \\
\hline Nov-10 & 69,868 & $\$ 16,203.88$ & $1,233,274$ & $\$ 140,961.10$ & $10.3 \%$ \\
\hline Dec-10 & 145,269 & $\$ 33,473.65$ & $1,123,506$ & $\$ 133,816.67$ & $20.0 \%$ \\
\hline Jan-11 & 187,432 & $\$ 30,860.66$ & $1,221,997$ & $\$ 111,355.14$ & $21.7 \%$ \\
\hline Feb-11 & 181,030 & $\$ 38,418.19$ & $1,128,090$ & $\$ 118,094.91$ & $24.5 \%$ \\
\hline Mar-11 & 140,691 & $\$ 29,480.37$ & $1,215,282$ & $\$ 119,328.21$ & $19.8 \%$ \\
\hline Apr-11 & 59,245 & $\$ 25,375.97$ & $1,114,563$ & $\$ 113,297.00$ & $18.3 \%$ \\
\hline May-11 & 41,271 & $\$ 9,150.33$ & $1,241,047$ & $\$ 127,646.59$ & $6.7 \%$ \\
\hline Jun-11 & 5,683 & $\$ 1,388.94$ & $1,341,941$ & $\$ 154,249.86$ & $0.9 \%$ \\
\hline Jul-11 & 1,733 & $\$ 495.09$ & $1,514,355$ & $\$ 160,886.99$ & $0.3 \%$ \\
\hline Aug-11 & 1,771 & $\$ 521.87$ & $1,462,934$ & $\$ 134,973.31$ & $0.4 \%$ \\
\hline Total & 843,506 & $\$ 188,043.74$ & $15,099,702$ & $\$ 1,559,511.89$ & $10.8 \%$ \\
\hline
\end{tabular}

*Electrical Demand (kW) not provided

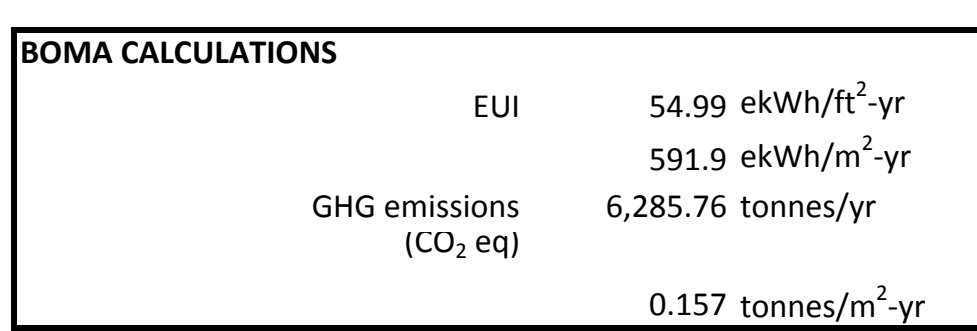

\section{ENERGY CALCULATIONS (CONSULTANT REPORT \& BOMA)}

\begin{tabular}{|c|c|}
\hline Retrofit Savings Total (consultant): & $\begin{array}{l}159.00 \mathrm{~kW} \\
215,300 \mathrm{kWh} \\
775.08 \mathrm{GJ} / \mathrm{yr} \text { consumption only } \\
20.25 \mathrm{MJ} / \mathrm{m}^{2}-\mathrm{yr}\end{array}$ \\
\hline
\end{tabular}

ENERGY CALCULATIONS (BOMA)

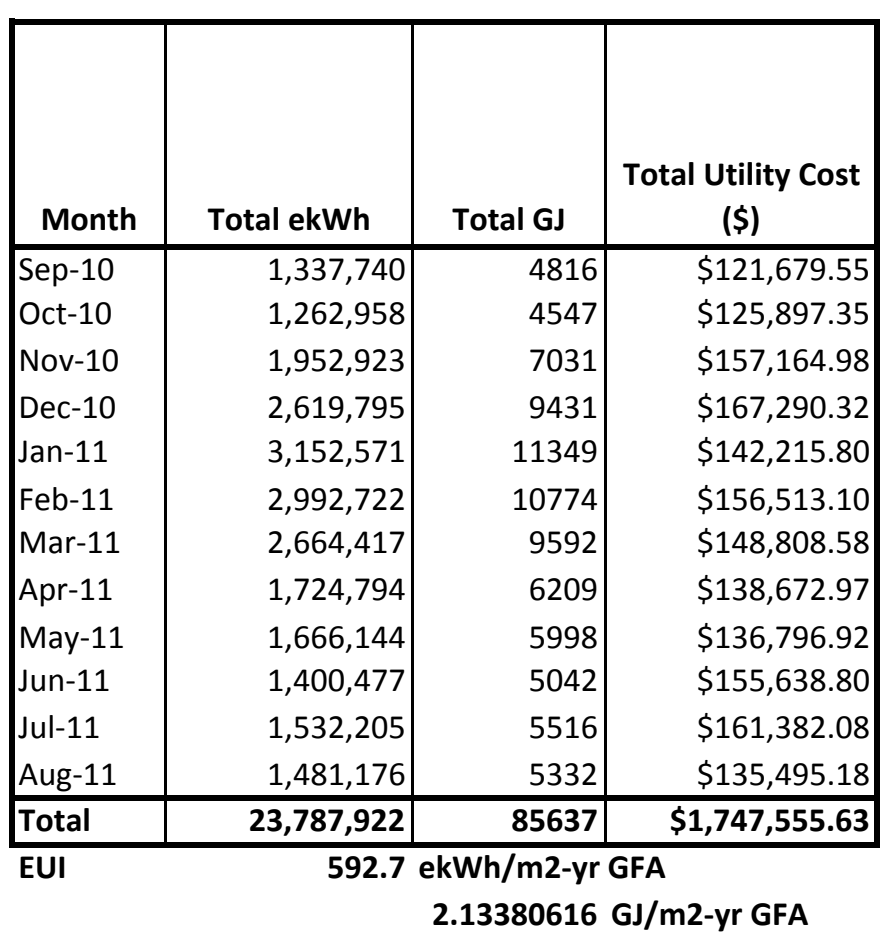

RETROFIT DATA (consultant report)

PROJECTED SAVINGS

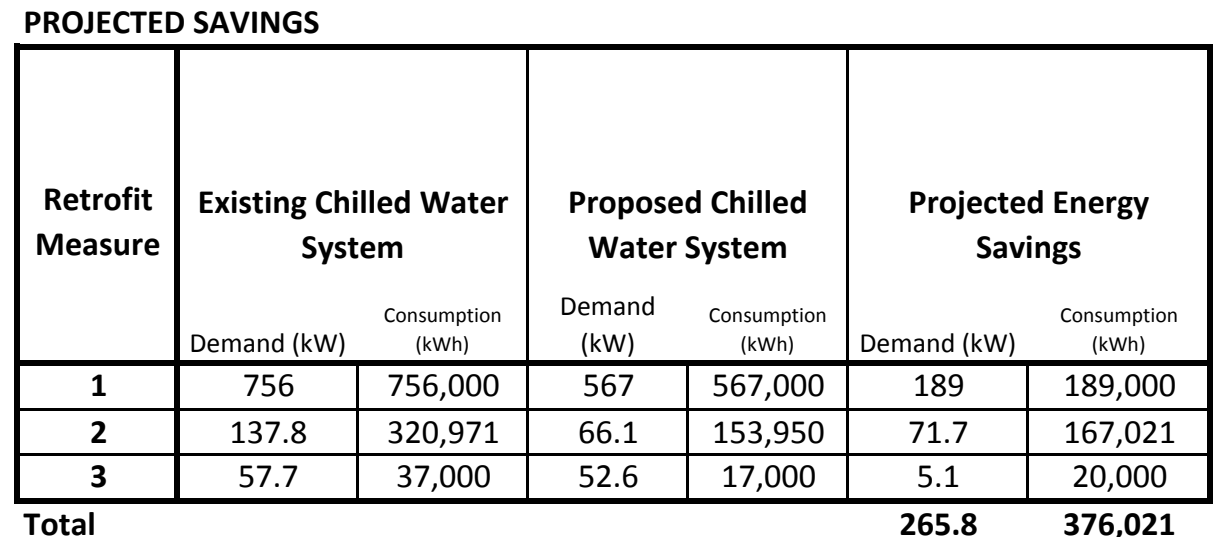

1. CHILLER REPLACEMENT

\begin{tabular}{|l|c|c|c|c|c|c|}
\cline { 2 - 7 } \multicolumn{1}{c|}{} & $\begin{array}{c}\text { Chiller Plant Capacity } \\
\text { (Tons) }\end{array}$ & $\begin{array}{c}\text { No. of } \\
\text { Chillers }\end{array}$ & $\begin{array}{c}\text { Load* } \\
\text { (Tons) }\end{array}$ & $\begin{array}{c}\text { Efficiency } \\
\text { (kW/ton) }\end{array}$ & Peak kW & Peak kWh \\
\hline Existing Chillers & 1400 & 2 & 840 & 0.9 & 756 & 756,000 \\
\hline New Chillers & 850 & 10 & 840 & 0.675 & 567 & 567,000 \\
\hline
\end{tabular}

* Load is $60 \%$ of namepla

* Assumed 1000 hours full load (consultant calculation).

2. CONDENSER WATER PUMP REPLACEMENT + VFD

2.13380616 GJ/m2-y $\$ 4 \mathrm{~m}^{2}$-yr GFA $\$ 45.66 \$ / \mathrm{m}^{2}$-yr office are

GJ $=26.968381 \mathrm{~m}^{3}$ natural gas (NRCan, NED

$1 \mathrm{GJ}=277.777778 \mathrm{ekWh}$

$\therefore 1 \mathrm{~m} 3$ natural gas $\approx 10.3001281 \mathrm{ekWh}$

\begin{tabular}{|lr|}
\hline GFA: & $431990 \mathrm{ft}^{2}$ \\
(BOMA) & $40133 \mathrm{~m}^{2}$ \\
\hline
\end{tabular}

$20.25 \mathrm{MJ} / \mathrm{m}^{2}-\mathrm{yr}$

There are two ways to calculate percentage energy savings - using consultant

report pre-retrofit data (a) and BOMA post-retrofit data (b).

(a) Pre-retrofit EUI (consultant report):

$\begin{array}{llr}\text { Year EUI (MJ } / \mathrm{m} 2 \text {-year) } & \text { eKwh/m } / \mathrm{m}^{2} \text {-yr } & \text { (b) Post-retfofit EUI (BOMA): } \\ 2010 / 2011 & 2133.806 \mathrm{MJ} / \mathrm{m}^{2}-\mathrm{yr}\end{array}$

$2008 \quad 2200 \quad 611.1 \quad \therefore$ pre-retrofit EUI $=2154.06 \mathrm{MJ} / \mathrm{m}^{2}-\mathrm{Yr}$

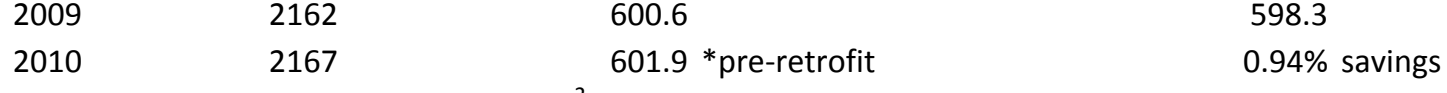

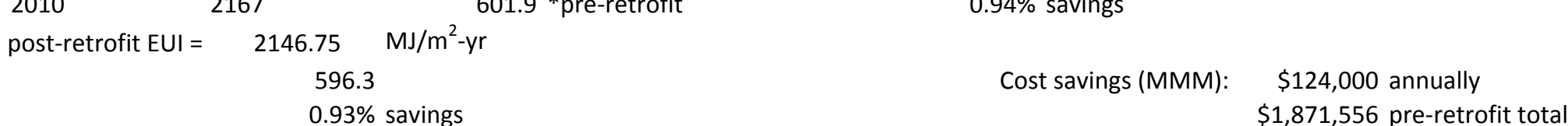

1 Natural Resources Canada, 2014, "Natural Gas: A Primer", http://www.nrcan.gc.ca/energy/natural-gas/5641 $6.6 \%$ savings annually

\begin{tabular}{|c|c|c|c|c|c|c|c|}
\hline ea & $\begin{array}{l}\text { No. of } \\
\text { Pumps }\end{array}$ & $\begin{array}{l}\text { Flow } \\
\text { (GPM) }\end{array}$ & Head $(\mathrm{ft})$ & $\begin{array}{c}\text { Motor } \\
\text { Efficiency }\end{array}$ & $\begin{array}{c}\text { Pump } \\
\text { Efficiency }\end{array}$ & $\begin{array}{l}\text { Demand } \\
(\mathrm{kW})\end{array}$ & $\begin{array}{c}\text { Consumption } \\
\text { (kWh) }\end{array}$ \\
\hline Existing Pumps & 2 & 2100 & 125 & $89 \%$ & $81 \%$ & 137.8 & 320,971 \\
\hline New Pumps & 2 & 1400 & 100 & $95 \%$ & $84 \%$ & 66.1 & 153,950 \\
\hline \multicolumn{8}{|c|}{ 3. CHILLED WATER PUMP VFDS } \\
\hline & $\begin{array}{l}\text { No. of } \\
\text { Pumps }\end{array}$ & $\begin{array}{l}\text { Flow } \\
\text { (GPM) }\end{array}$ & Head $(\mathrm{ft})$ & $\begin{array}{c}\text { Motor } \\
\text { Efficiency }\end{array}$ & $\begin{array}{l}\text { Pump } \\
\text { Efficiency }\end{array}$ & $\begin{array}{l}\text { Demand } \\
(\mathrm{kW})\end{array}$ & $\begin{array}{c}\text { Consumption } \\
\text { (kWh) }\end{array}$ \\
\hline Existing Pumps & 2 & nd & 95 & $89 \%$ & $84 \%$ & 57.7 & 37,000 \\
\hline New Pumps & 2 & 1200 & 95 & $95 \%$ & $86 \%$ & 52.6 & 17,000 \\
\hline
\end{tabular}

MEASURED SAVINGS (BOMA)

\begin{tabular}{|c|cc|cc|cc|}
\hline $\begin{array}{c}\text { Retrofit } \\
\text { Measure }\end{array}$ & $\begin{array}{c}\text { Existing Chilled Water } \\
\text { System } \\
\text { Demand }(\mathrm{kW})\end{array}$ & $\begin{array}{c}\text { Proposed Chilled } \\
\text { Water System } \\
(\mathrm{kWh})\end{array}$ & $\begin{array}{c}\text { Projected Energy } \\
\text { Savings } \\
\text { Demand } \\
(\mathrm{kW})\end{array}$ & $\begin{array}{c}\text { consumption } \\
(\mathrm{kWh})\end{array}$ & $\begin{array}{c}\text { Demand }(\mathrm{kW}) \\
\text { consumption } \\
(\mathrm{kWWh})\end{array}$ \\
\hline $\mathbf{1}$ & 672 & 671,600 & 567 & 567,000 & 105 & 104,600 \\
\hline $\mathbf{2}$ & 133 & 207,400 & 66 & 103,700 & 67 & 103,700 \\
\hline $\mathbf{3}$ & 53 & 82,800 & 66 & 75,800 & -13 & 7,000 \\
\hline Total
\end{tabular}

Civil Engineering

UNIVERSITY of toronto 


\begin{tabular}{|c|c|c|c|c|c|c|c|c|c|c|c|c|c|c|c|c|c|}
\hline & & & & & & & & FINANCIAL L & & & $=$ Occupancy & $y$ & & & & & \\
\hline Year & $\begin{array}{c}\text { Direct Asking } \\
\text { Rate } \$ / \mathrm{m}^{2}\end{array}$ & \begin{tabular}{|l} 
D.A.R. \% +/- \\
Compared to \\
Pre-Retrofit
\end{tabular} & $\begin{array}{c}\text { Total Additional } \\
\operatorname{Rent}\left(\$ / \mathrm{m}^{2}\right)\end{array}$ & $\begin{array}{c}\text { T.A.R. } \%+/- \\
\text { Compared to Pre } \\
\text { Retrofit }\end{array}$ & $\begin{array}{c}\text { Effective Total } \\
\text { Additional Rent } \\
\left(\$ / \mathrm{m}^{2}\right)\end{array}$ & $\begin{array}{c}\text { Effective T.A.R. } \\
\%+/ \text { - Compared } \\
\text { to Pre-Retrofit }\end{array}$ & $\begin{array}{c}\text { Operating } \\
\text { Costs }\left(\$ / \mathbf{m}^{2}\right)\end{array}$ & $\begin{array}{c}\text { Office Standard } \\
\left(0 \& \mathrm{M} / \mathrm{m}^{2}\right)\end{array}$ & $\begin{array}{l}\text { O\&M \% }+/- \\
\text { Compared to } \\
\text { Pre-Retrofit }\end{array}$ & \begin{tabular}{|c|} 
Total Estimated \\
Direct Rent \\
$\left(\$ / \mathrm{m}^{2}\right)$
\end{tabular} & $\begin{array}{c}\text { T.E.D.R. \% +/- } \\
\text { Compared to Pre- } \\
\text { Retrofit }\end{array}$ & $\begin{array}{c}\text { Total Available } \\
\text { Area }\left(\mathrm{m}^{2}\right)\end{array}$ & $\begin{array}{c}\text { Total } \\
\text { Available } \\
\text { Rate }(\%)\end{array}$ & \begin{tabular}{|l|} 
Occupancy \\
Rate (Altus)
\end{tabular} & $\begin{array}{c}\text { Occ. } \%+/- \\
\text { Compared to } \\
\text { Pre-Rertofit }\end{array}$ & $\begin{array}{c}\text { Occupancy } \\
\text { Rate } \\
\text { (operator) }\end{array}$ & \begin{tabular}{|c} 
Occ. $\%+/-$ \\
Compared \\
to Pre- \\
Retrofit
\end{tabular} \\
\hline \multicolumn{18}{|c|}{ BUILDING A } \\
\hline 2005 & $\$ 344.44$ & & $\$ 316.46$ & & $\$ 295.17$ & & & & & $\$ 660.90$ & & $14,333.9$ & $6.7 \%$ & $93.3 \%$ & & & \\
\hline 2006 & $\$ 344.44$ & & $\$ 322.06$ & & $\$ 278.66$ & & & & & $\$ 666.50$ & & $28,709.9$ & $13.5 \%$ & $86.5 \%$ & & & \\
\hline 2007 & $\$ 322.92$ & & $\$ 323.78$ & & $\$ 303.11$ & & & & & $\$ 646.70$ & & $13,597.9$ & $6.4 \%$ & $93.6 \%$ & & & \\
\hline 2008 & nd & & $\$ 334.65$ & & $\$ 293.63$ & & & & & nd & & $26,118.8$ & $12.3 \%$ & $87.7 \%$ & & & \\
\hline 2009 & $\$ 328.30$ & & $\$ 333.25$ & & $\$ 283.05$ & & & & & $\$ 661.55$ & & $32,096.8$ & $15.1 \%$ & $84.9 \%$ & & & \\
\hline 2010 & $\$ 293.32$ & $-10.7 \%$ & $\$ 333.25$ & $0.0 \%$ & $\$ 292.74$ & $3.4 \%$ & & & & $\$ 626.57$ & $-5.3 \%$ & $25,900.5$ & $12.2 \%$ & $87.8 \%$ & $2.9 \%$ & & \\
\hline 2011 & $\$ 296.01$ & $-9.8 \%$ & $\$ 320.76$ & $-3.7 \%$ & $\$ 275.76$ & $-2.6 \%$ & & & & $\$ 616.77$ & $-6.8 \%$ & $29,892.0$ & $14.0 \%$ & $86.0 \%$ & $1.0 \%$ & & \\
\hline 2012 & $\$ 330.99$ & $0.8 \%$ & $\$ 316.46$ & $-5.0 \%$ & $\$ 269.93$ & $-4.6 \%$ & & & & $\$ 647.45$ & $-2.1 \%$ & $31,324.7$ & $14.7 \%$ & $85.3 \%$ & $0.4 \%$ & & \\
\hline 2013 & $\$ 330.99$ & $0.8 \%$ & $\$ 316.46$ & $-5.0 \%$ & $\$ 278.22$ & $-1.7 \%$ & & & & $\$ 647.45$ & $-2.1 \%$ & $25,746.1$ & $12.1 \%$ & $87.9 \%$ & $3.0 \%$ & & \\
\hline 2014 & nd & nd & $\$ 323.35$ & $-3.0 \%$ & $\$ 280.32$ & $-1.0 \%$ & & & & nd & nd & $28,356.0$ & $13.3 \%$ & $86.7 \%$ & $1.8 \%$ & & \\
\hline \multicolumn{18}{|c|}{ BUILDING B } \\
\hline 2005 & $\$ 322.92$ & & $\$ 325.61$ & & $\$ 292.74$ & & nd & & & $\$ 648.52$ & & $9,153.2$ & $10.1 \%$ & $89.9 \%$ & & & \\
\hline 2006 & $\$ 333.68$ & & $\$ 325.61$ & & $\$ 195.97$ & & nd & & & $\$ 659.29$ & & $36,097.5$ & $39.8 \%$ & $60.2 \%$ & & & \\
\hline 2007 & $\$ 333.68$ & & $\$ 336.05$ & & $\$ 207.28$ & & nd & & & $\$ 669.73$ & & $34,741.0$ & $38.3 \%$ & $61.7 \%$ & & & \\
\hline 2008 & $\$ 333.68$ & & $\$ 345.52$ & & $\$ 291.35$ & & $\$ 145.74$ & & & $\$ 679.20$ & & $14,213.2$ & $15.7 \%$ & $84.3 \%$ & & & \\
\hline 2009 & $\$ 333.68$ & & $\$ 340.68$ & & $\$ 251.84$ & & $\$ 144.13$ & & & $\$ 681.35$ & & $23,641.2$ & $26.1 \%$ & $73.9 \%$ & & & \\
\hline 2010 & nd & & $\$ 340.68$ & & $\$ 211.19$ & & $\$ 143.16$ & & & nd & & $34,460.9$ & $38.0 \%$ & $62.0 \%$ & & & \\
\hline 2011 & nd & & $\$ 340.68$ & & $\$ 243.15$ & & $\$ 143.70$ & & & nd & & $25,954.7$ & $28.6 \%$ & $71.4 \%$ & & & \\
\hline 2012 & $\$ 320.23$ & & $\$ 342.29$ & $0.5 \%$ & $\$ 323.74$ & $33.1 \%$ & $\$ 152.31$ & & & $\$ 662.52$ & & $4,913.0$ & $5.4 \%$ & $94.6 \%$ & $23.2 \%$ & & \\
\hline 2013 & $\$ 322.92$ & & $\$ 353.06$ & $3.6 \%$ & $\$ 327.58$ & $34.7 \%$ & $\$ 161.57$ & & & $\$ 675.97$ & & $6,543.3$ & $7.2 \%$ & $92.8 \%$ & $21.4 \%$ & & \\
\hline 2014 & nd & & $\$ 353.06$ & $3.6 \%$ & $\$ 328.12$ & $34.9 \%$ & $\$ 176.53$ & & & nd & & $6,404.5$ & $7.1 \%$ & $92.9 \%$ & $21.6 \%$ & & \\
\hline \multicolumn{18}{|c|}{ BUILDING C } \\
\hline 2005 & $\$ 301.39$ & & $\$ 332.50$ & & $\$ 324.72$ & & nd & & & $\$ 633.89$ & & $2,888.5$ & $2.3 \%$ & $97.7 \%$ & & & \\
\hline 2006 & $\$ 333.68$ & & $\$ 332.50$ & & $\$ 324.40$ & & nd & & & $\$ 666.18$ & & $3,008.9$ & $2.4 \%$ & $97.6 \%$ & & & \\
\hline 2007 & $\$ 333.68$ & & $\$ 334.76$ & & $\$ 321.72$ & & nd & & & $\$ 668.44$ & & $4,809.2$ & $3.9 \%$ & $96.1 \%$ & & & \\
\hline 2008 & $\$ 333.68$ & & $\$ 339.06$ & & $\$ 287.95$ & & $\$ 145.53$ & & & $\$ 672.74$ & & $18,617.6$ & $15.1 \%$ & $84.9 \%$ & & & \\
\hline 2009 & $\$ 333.68$ & & $\$ 336.91$ & & $\$ 286.12$ & & $\$ 142.62$ & & & $\$ 672.74$ & & $18,617.6$ & $15.1 \%$ & $84.9 \%$ & & & \\
\hline 2010 & $\mathrm{nd}$ & & $\$ 336.91$ & & $\$ 291.67$ & & $\$ 142.62$ & & & nd & & $16,583.0$ & $13.4 \%$ & $86.6 \%$ & & & \\
\hline 2011 & nd & & $\$ 336.91$ & & $\$ 305.90$ & & $\$ 143.91$ & & & nd & & $11,365.1$ & $9.2 \%$ & $90.8 \%$ & & & \\
\hline 2012 & $\$ 333.68$ & & $\$ 331.53$ & $-1.6 \%$ & $\$ 309.60$ & $1.2 \%$ & $\$ 151.34$ & $5.2 \%$ & & $\$ 665.21$ & & $8,169.0$ & $6.6 \%$ & $93.4 \%$ & $2.6 \%$ & & \\
\hline 2013 & $\$ 333.68$ & & $\$ 333.68$ & $-1.0 \%$ & $\$ 321.05$ & $5.0 \%$ & $\$ 155.11$ & $7.8 \%$ & & $\$ 667.36$ & & $4,675.6$ & $3.8 \%$ & $96.2 \%$ & $5.4 \%$ & & \\
\hline 2014 & nd & & $\$ 333.68$ & $-1.0 \%$ & $\$ 317.61$ & $3.8 \%$ & $\$ 161.46$ & $12.2 \%$ & & nd & & $5,948.4$ & $4.8 \%$ & $95.2 \%$ & $4.4 \%$ & & \\
\hline \multicolumn{18}{|c|}{ BUILDING D } \\
\hline 2005 & $\$ 182.99$ & & $\$ 194.50$ & & $\$ 160.74$ & & & nd & & $\$ 377.49$ & & $6,643.4$ & $17.4 \%$ & $82.6 \%$ & & nd & \\
\hline 2006 & $\$ 201.82$ & & $\$ 192.78$ & & $\$ 176.91$ & & & nd & & $\$ 394.60$ & & $3,151.4$ & $8.2 \%$ & $91.8 \%$ & & nd & \\
\hline 2007 & $\$ 255.64$ & & $\$ 197.52$ & & $\$ 183.79$ & & & nd & & $\$ 453.16$ & & $2,660.3$ & $7.0 \%$ & $93.0 \%$ & & nd & \\
\hline 2008 & $\$ 285.24$ & & $\$ 208.93$ & & $\$ 203.05$ & & & nd & & $\$ 494.17$ & & $1,076.4$ & $2.8 \%$ & $97.2 \%$ & & nd & \\
\hline 2009 & nd & & $\$ 217.32$ & & $\$ 210.97$ & & & $\$ 112.91$ & & nd & & $1,119.8$ & $2.9 \%$ & $97.1 \%$ & & $98.9 \%$ & \\
\hline 2010 & nd & & $\$ 226.28$ & & $\$ 215.21$ & & & $\$ 118.40$ & & nd & & $1,873.5$ & $4.9 \%$ & $95.1 \%$ & & $97.7 \%$ & \\
\hline 2011 & nd & & $\$ 227.98$ & & $\$ 210.32$ & & & $\$ 131.75$ & & nd & & $2,964.8$ & $7.7 \%$ & $92.3 \%$ & & $97.2 \%$ & \\
\hline 2012 & nd & & $\$ 229.59$ & $0.7 \%$ & $\$ 211.58$ & $0.6 \%$ & & $\$ 124.97$ & $-5.1 \%$ & nd & & $3,003.1$ & $7.8 \%$ & $92.2 \%$ & $-0.1 \%$ & $97.7 \%$ & $0.5 \%$ \\
\hline 2013 & nd & & $\$ 232.72$ & $2.1 \%$ & $\$ 215.16$ & $2.3 \%$ & & $\$ 130.89$ & $-0.7 \%$ & nd & & $2,887.3$ & $7.5 \%$ & $92.5 \%$ & $0.2 \%$ & $99.7 \%$ & $2.5 \%$ \\
\hline 2014 & nd & & $\$ 234.65$ & $2.9 \%$ & $\$ 208.53$ & $-0.8 \%$ & & $\$ 129.70$ & $-1.6 \%$ & nd & & $4,260.6$ & $11.1 \%$ & $88.9 \%$ & $-3.4 \%$ & $98.7 \%$ & $1.5 \%$ \\
\hline
\end{tabular}

要 Civil Engineering

UNIVERSITY OF TORONTO 